\title{
Col·lecció Humanitats
}
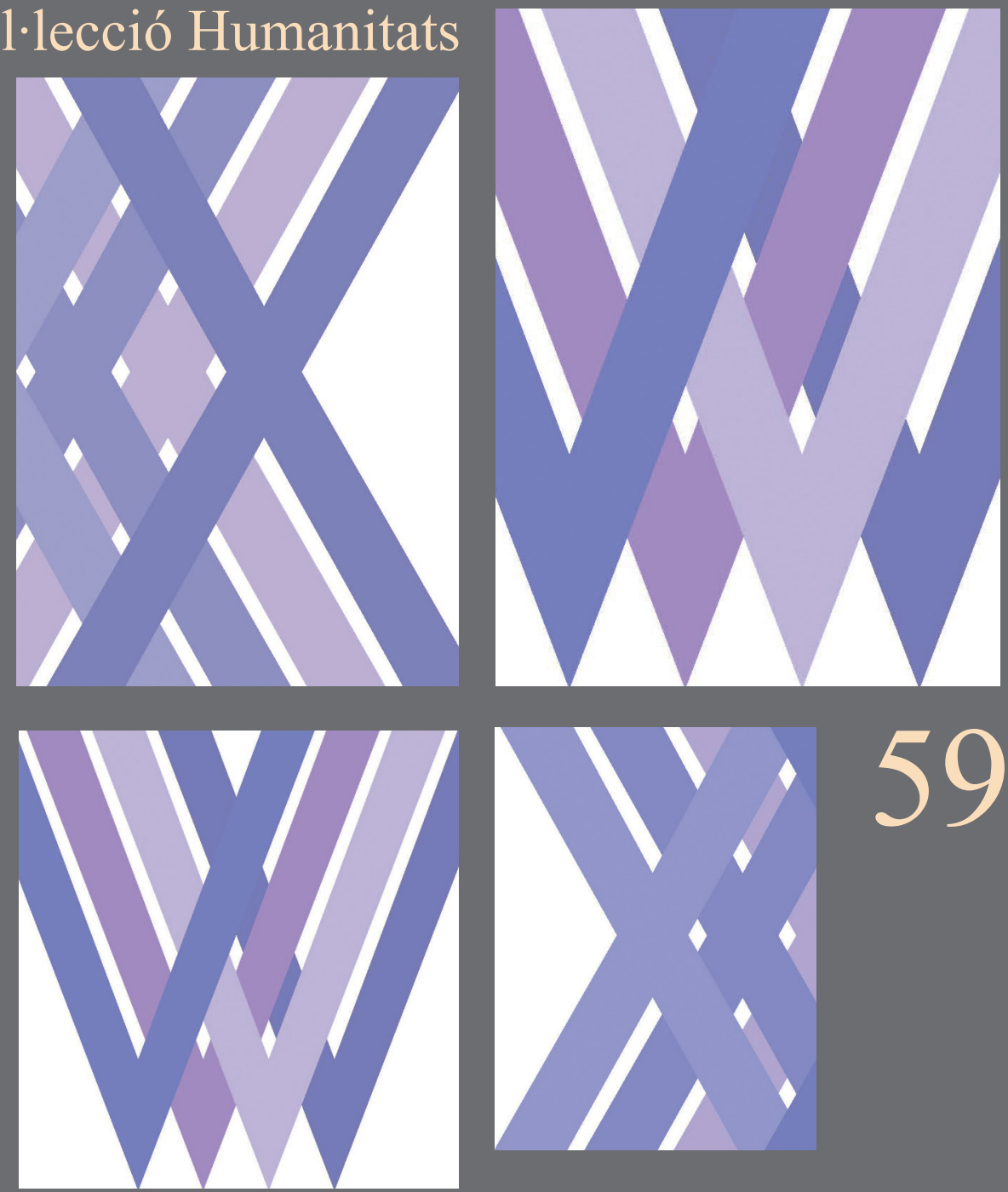

\section{COMLOC 2018: EL NEGOCIO PUBLICITARIO EN LA SOCIEDAD DIGITAL}

Cristina Gonzalez Oñate y

Carlos Fanjul Peyró (eds.)

\section{UNIVERSITAT}


Col·lecció «Humanitats»

Núm. 59

\section{COMLOC 2018: EL NEGOCIO PUBLICITARIO EN LA SOCIEDAD DIGITAL}


Noms: Congreso de Comunicación Local (15è : 2018 : Castelló), autor | González Oñate, Cristina, editor literari | Fanjul Peyró, Carlos, editor literari | Universitat Jaume I. Publicacions, entitat editora

Títol: COMLOC 2018 : el negocio publicitario en la sociedad digital / Cristina Gonzalez Oñate y Carlos Fanjul Peyró (eds.)

Descripció: Castelló de la Plana: Publicacions de la Universitat Jaume I. Servei de Comunicació i Publicacions, [2019] | Col·lecció: Humanitats; 59 | Inclou bibliografia Identificadors: ISBN 978-84-17429-77-5

Matèries: Publicitat per Internet — Congressos

Classificació: CDU 659.1:004.738.5(063)| IBIC KJSA

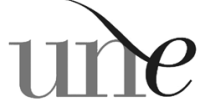

Unión de Editoriales UNIVERSITARIAs Españolas
Publicacions de la Universitat Jaume I és una editorial membre de l'unE, cosa que garanteix la difusió i comercialització de les seues obres en els àmbits nacional i internacional. www.une.es.

C Del text: Els autors i les autores, 2019

C De la present edició: Publicacions de la Universitat Jaume I, 2019

Il·lustració de la coberta: Shaila García Catalán

Edita: Publicacions de la Universitat Jaume I. Servei de Comunicació i Publicacions

Campus del Riu Sec. Edifici Rectorat i Serveis Centrals

12071 Castelló de la Plana

http:/www.tenda.uji.es e-mail: publicacions@uji.es

ISBN: 978-84-17429-77-5

DOI: http://dx.doi.org/10.6035/Humanitats.2019.59

Dipòsit Legal: CS-482-2019

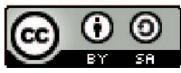

Reconeixement-CompartirIgual

CC BY-SA

Aquest text està subjecte a una llicència Reconeixement-CompartirIgual de Creative Commons, que permet copiar, distribuir i comunicar públicament l'obra sempre que s'especifique l'autoria i el nom de la publicació fins i tot amb objectius comercials i també permet crear obres derivades, sempre que siguen distribuïdes amb aquesta mateixa llicència.

http://creativecommons.org/licenses/by-sa/3.0/legalcode 


\section{Índex}

Introducción

Cristina González Oñate, Carlos Fanjul Peyró

\section{PONENCIAS}

La evolución de la creatividad y la tecnología en el ámbito de los perfiles

M. ${ }^{a}$ Rosario García Cubells

Neuromarketing y publicidad: análisis de casos prácticos empleando el electroencefalograma, respuesta dermoeléctrica, expresión facial implícita, eye-tracking y otras variables Ubaldo Cuesta

Competencias digitales para un consumo saludable en redes Carmen Marta Lazo 


\section{COMUNICACIONES PRESENTADAS}

Innovación en la difusión del arte en contextos digitales:

la gestión de la comunicación del Museo Sorolla en internet y redes sociales

Francisco Cabezuelo Lorenzo, Raquel Caerols Mateo, Mónica Viñarás Abad

La oferta de pódcast de los medios locales como oportunidad para ganar audiencia joven y estrategia de nuevos ingresos Andrea Delgado Hernández

Insight trascendente, tendencias espirituales en publicidad Samuel Gil Soldevilla

Los influencers en la comunicación local Francisco Jiménez Ruiz

Diseño y evaluación de un modelo de marketing y comunicación móviles para la captación y fidelización de estudiantes en la Universidad CEU Cardenal Herrera José Antonio Martínez Gómez

La interacción entre las marcas y sus seguidores en Facebook: el caso de Hugo Boss Marián Navarro-Beltrá, Susana Miquel-Segarra, Irene García Medina

La narrativa transmedia: el caso de LEGO José Luis Roglá Lacueva 
La influencia del abandono de las redes sociales en la marca personal, estudio de caso: el Rubius en YouTube

Álex Rubio-Navalón, Stanislava Mrkonjic

La pantalla transparente: cómo la comunicación institucional puede ser más transparente apoyándose en las nuevas tecnologías

Radu Trăscău

Discurso de clausura

Carlos Fanjul Peyró. Director académico del ComLoc 2018 


\title{
INTRODUCCIÓN
}

\section{EI negocio publicitario en la sociedad digital}

\author{
Cristina González Oñate \\ Carlos Fanjul Peyró
}

Directores académicos del ComLoc 2018

Universitat Jaume I

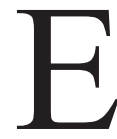

L SIGLO XXI SE CARACTERIZA POR la globalización que ha permitido internet y la rápida evolución de la tecnología. En el campo publicitario, este contexto ha supuesto un cambio en la concepción de la comunicación para las empresas. La denominada sociedad de la información y del conocimiento permite la agrupación «no física pero sí real» de personas por afinidades ideológicas, culturales, gremiales... o por compartir aficiones, gustos, preferencias... En definitiva, una segmentación de públicos que era difícil de conseguir en el mundo offline, pero cada vez más sencillo de obtener en el mundo online. Lo cual permite hacer más eficaz que nunca la comunicación empresarial y la publicidad en estos entornos.

La multiplicación de canales, tecnologías y dispositivos electrónicos propician un cambio drástico en el comportamiento del consumidor, ya que la recepción y las conversaciones que se generaban alrededor de medios y comunicaciones tradicionales, se comienzan a combinar con la recepción y participación multipantalla, obteniendo una experiencia más completa, real e interactiva. El consumidor actual, con su capacidad de interacción con la marca y con otros consumidores, pasa a tener la consideración de canal de comunicación.

La web semántica (o web 3.0) permite un uso más eficiente de los contenidos, utilizando un lenguaje más natural en las búsquedas y obteniendo información relevante para el usuario. Y la denominada web 4.0 promete una interacción mucho más eficiente y personalizada en la que las «máquinas» comprenderán mejor el lenguaje natural del ser humano 
y se utilizará la información contextual proporcionada por accesorios tales como móviles, tabletas, smartwatch, etc. Nunca hasta ahora se había podido obtener tanta información sobre un potencial cliente. El big data y las nuevas tecnologías permiten generar impactos publicitarios prácticamente personalizados en sujetos que se encuentran físicamente cerca de los establecimientos de compra. Todos estos avances han permitido la creación de mensajes publicitarios relevantes para el público objetivo en un momento preciso y teniendo en cuenta la ubicación del receptor de forma que la eficacia de la inversión en publicidad aumenta. Además, la interactividad que se puede implementar en las piezas publicitarias convierte a esta en conversación. La posibilidad de identificación de los perfiles de usuarios permite personalizar los mensajes. Y la opción de una medición de la eficacia publicitaria mucho más ágil, casi inmediata, ha abierto puertas a una nueva forma de trabajar en comunicación y publicidad.

Debido a estos profundos cambios estructurales en el negocio de la publicidad, se ha hecho necesario reinventar el entorno de la comunicación y las agencias han tenido que adaptar sus procesos de trabajo, cambiando la relación entre estas y los anunciantes, y dando lugar al nacimiento de nuevos modelos de empresas de publicidad, tanto a nivel internacional como nacional y local.

Dentro del proyecto dirigido por la Dra. Cristina González Oñate, El negocio publicitario en la sociedad digital: estructura de agencia, perfiles profesionales y nuevas tendencias creativas (Plan de Promoción Universitat Jaume I P1-1B2015-27) se ha realizado un análisis de cómo ha afectado todo este nuevo contexto comunicativo a la evolución y transformación de las agencias de publicidad ubicadas en la Comunidad Valenciana. Tras la investigación realizada, se llegan a conclusiones tales como que la agencia de publicidad tradicional, tal y como se concebía en el siglo xx, ya no existe. Este tipo de agencias, o bien han desaparecido, o bien se han adaptado al nuevo contexto, no sin dificultades, ya que el sector de la comunicación está en constante cambio y evolución. Adaptarse al entorno digital (proceso de digitalización) y sus desarrollos (continua atención a las novedades del mercado) se ha convertido en una 
necesidad para la agencia de hoy. Por tanto, el panorama actual del sector publicitario de la Comunidad Valenciana puede definirse por la tendencia a la digitalización y la aparición de nuevos modelos de negocio en un entorno altamente competitivo.

Actualmente, en las agencias locales valencianas, lo que prima es una combinación entre publicidad, diseño y digital, todo ello bajo un halo constante de creatividad y estrategia, ambos elementos considerados esenciales para la supervivencia y el éxito de la comunicación empresarial.

Con el ComLoc de 2018 esperamos obtener entre todos los participantes una visión cenital, una fotografía de la situación del sector para comprender cómo ha cambiado y qué ha ocurrido. El fin es aunar universidad y empresa, y el ComLoc es un foro perfecto para ello, pues académicos, profesionales y estudiantes del ámbito de la publicidad van a compartir sus experiencias con el fin de afinar y potenciar esta relación. 


\section{PONENCIAS}




\title{
LA EVOLUCIÓN DE LA CREATIVIDAD \\ Y LA TECNOLOGÍA EN EL ÁMBITO \\ DE LOS PERFILES
}

\author{
M. ${ }^{a}$ Rosario García Cubells \\ Universidad CEU Cardenal Herrera
}

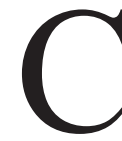

HARI GARCÍA eS UNA PROFESIONAL DE la comunicación publicitaria con una larga trayectoria laboral. Su comunicación realiza un breve recorrido sobre lo que ha sido y es ahora la profesión publicitaria, profundizando en concreto en el rol de creativo publicitario.

¿Qué está pasando y qué puede pasar en el panorama publicitario?

Se ha funcionado durante muchos años en comunicación publicitaria y en publicidad a nivel creativo con un determinado proceso que se aplicaba en cada encargo del anunciante. Ahora las cosas han cambiado sustancialmente. La tecnología ha irrumpido en ese proceso con una velocidad que es «imparable».

Hay que situarse en ese punto. Bien es cierto que antes era más fácil porque existían menos entradas, menos inputs, que pudieran alterar la forma de trabajar. No es que ahora sea difícil, ahora es muy interesante, pero tecnológicamente hay que ponerse al día. Y no solo en la tecnología, sino también en cuanto a la capacidad de crear y mandar mensajes a usuarios, que tienen diferentes formas de comportarse y que viven en ese ámbito tecnológico.

El maestro Marshall McLuhan (1951) dijo: «el nuevo medio, el que sea que venga, podría ser la extensión de la conciencia, incluirá la televisión como contenido y no como medio». Alguien con ideas tan impresionantes como la aldea global, el medio es el mensaje y que fue un visionario con una visión de futuro paradigmática, en el año 51 del siglo pasado, ya describía por donde se mueve el marketing de contenidos. Partimos de esta cita, ya que ella nos lleva al mundo digital, porque el

* Ponencia transcrita íntegramente a partir de su exposición, por lo tanto, el texto se ajusta más al estilo oral que al escrito. 
marketing de contenidos está supeditado este; a pesar de que aún se lleven a cabo muchas acciones offline, siempre acabaremos en ámbito de difusión online.

Al principio, el proceso creativo de trabajo era el conocido; el anunciante daba un briefing, convocaba a su agencia o bien organizaba un concurso entre agencias, las llamadas mainstream, no digitales. Se planteaba una estrategia, se generaba una campaña, se aprobaba por parte del anunciante y se difundía y distribuía a través de los medios masivos para su recepción por el consumidor. El único retorno de inversión era el aumento de ventas, la continuidad de ellas o la fidelización frente a la competencia. Y si se hacía bien, se conseguía un posicionamiento diferenciado, notorio, distinto, que permitía mantener la cabeza alta ante la competencia.

La infraestructura de la agencia se materializaba en un departamento de estrategia que llamábamos Departamento de Cuentas, donde se recibían los briefings y se llevaba la relación con el cliente a cargo de directores, ejecutivos y auxiliares de cuentas... Este departamento sigue existiendo, pero con diferentes nominaciones, según cada organización, añadiendo que ha emergido la figura del planner, que tiene un cometido mucho más amplio que la relación con el cliente.

Planners y creativos van de la mano. El planner planifica, investiga, proporciona datos del consumidor, de la competencia y deriva en una estrategia planificadora para hacer mensajes o acciones que interesen.

En cuanto a la creatividad se producía con el modelo tradicional. Un dato curioso es que no se utilizaba la palabra ni el concepto insight, lo utilizaban los psicólogos, era una palabra que existía, de hecho en todas las escuelas de psicología encontramos la definición de insight.

En publicidad, se utilizaban los datos del briefing para estudiar al consumidor, para buscar esa idea feliz con el grupo creativo, director de arte, director creativo, copy y las personas que les ayudaban en aquellos momentos, lo que ahora son los diseñadores gráficos antes llamados arte finalistas.

Las nuevas tecnologías han modificado sustancialmente este proceso. Empiezan a surgir agencias de carácter digital y las agencias habituales, 
las que se llevaban todos los premios en los certámenes publicitarios, las que funcionaban -no podemos negar la tremenda labor que se hizo con las marcas- tenían recelos tecnológicos.

Estas nuevas agencias digitales, aunque sean de menor tamaño, ya que trabajan con presupuestos mucho más accesibles, provocan una nueva relación con el consumidor; les comen el terreno a las grandes agencias y empiezan a crear su propio ámbito tecnológico. Es la competencia. Muchas agencias digitales tecnológicas pequeñas, que posteriormente se han hecho grandes, les «robaban» mercado y clientes. «Robar», no en el mal sentido de la palabra, porque existe la libertad de mercado y todo el mundo puede acceder a conseguir clientes nuevos, pero tenían un presupuesto menor, mejores soluciones $\mathrm{y}$, además, desde el principio entendían mucho mejor al consumidor, porque se movían en el ámbito de las nuevas tecnologías como su espacio natural.

Ante este panorama, o se producía un cambio en las agencias convencionales o lo tenían complicado.

Surge, pues, en las agencias, una necesidad vital de entender internamente la tecnología. La implantación tecnológica cayó de golpe en el ámbito global de la comunicación publicitaria. Y, desde luego, se plantearon nuevas formas de comunicar y nuevas estrategias.

Un ejemplo: una estrategia que vino a sustituir a otra (o a complementarla) es la conocida «transmedia», que complementa al método que ya se utilizaba, la llamada estrategia 360 , que versa sobre pensar ideas que pudieran adaptarse a todos los medios de difusión posibles, todos ellos convencionales, y con el objetivo de obtener la misma eficacia. La clave era la adaptación. Es decir, una campaña realizada específicamente en televisión que tuviera una conectividad en radio, publicidad exterior, cualquier otro medio impreso y en todos ellos con la misma eficacia. El concepto «transmedia» rompe ese esquema. Como define Diego Rivera, transmedia es «un proceso narrativo basado en el fraccionamiento intencionado del contenido y su diseminación a través de múltiples plataformas, soportes y canales, con el fin de que cada medio cuente una parte específica y complementaria de la historia». En cada medio no se adapta, se aporta sobre el concepto. Se trata de enganchar a los consumidores y 
perseguir cualquier trama que nos plantean a través de los diferentes medios. Interactividad y participación.

Un ejemplo paradigmático para el funcionamiento del transmedia es el caso de la campaña de IKEA — «La otra carta»-. Esto se tradujo en una acción transmedia absoluta. Lanzaron dos spots en televisión, crearon el evento «Gestiona a tus hijos», realizaron una web para seguir aportando contenido, encuentros con blogueros, aprovecharon para obtener datos de contacto de potenciales clientes, etc.

Otro ejemplo muy popular: Operación Triunfo 2017. La diferencia entre la primera edición y от 2017 es que el usuario, que ha estado esperando que llegara, ha participado de manera distinta, lo que ha proporcionado el éxito de la acción. Los personajes se han desnudado, en el sentido figurado, delante de su audiencia, les han podido preguntar, han conocido sus vidas, han participado en chats, opinaban en las galas... Un tráfico interactivo, porque se contestaba de inmediato a la gente a través de las redes sociales y medios online. Estuvo tan bien organizado, que generó una gran acción de publicity, es decir que todo esto trascienda a cualquier otro medio incluidos los convencionales.

Para que esto funcione, las acciones tienen que estar dotadas de «contenido». Tenemos que funcionar con el grupo de trabajo fundamentándonos en marketing de contenidos, es decir, en algo que tiene que interesar al usuario. Si es aburrido, si no proporciona un beneficio, aunque sea emocional, no interesa.

Es una adaptación a una nueva forma de hacer, porque hay tal ruido en la red y en lo digital, de todo lo que se propone por parte de anunciantes y marcas, que aunque las ideas sean magníficas, pueden verse catapultadas. Sin embargo, cuando la gente es la que está diciendo «algo me gusta o no me gusta», provoca viralidad, información incontrolada muchas veces, e incluso reacciones inmediatas, como campañas que se han tenido que retirar o modificar atendiendo al reclamo de las redes sociales.

Un ejemplo reciente es la campaña para la difusión de los premios Jaume I de la Generalitat Valenciana, que pretende reivindicar el puesto social que le corresponde a la investigación y a la ciencia. Se ha realizado una campaña de publicidad exterior y en medios impresos, así como en 
la red. El concepto creativo se fundamenta en tratar de motivar a la gente para que «dejemos de prestarle atención a los tópicos que nos definen y demos cabida en nuestra mente, en nuestra vida a lo importante que es la ciencia y la investigación». La forma de expresión creativa consistió en tachar palabras que representan los tópicos y sustituirlos por ciencia, investigación, innovación.... Por ejemplo: «Flamenco, España no solo es flamenco también tiene que ser investigación», igualmente con el término «Paella». Pero ¿qué ha sucedido? Arcángel, un cantaor flamenco bastante conocido, viaja a Valencia y ve una marquesina con la cartelería de esta campaña y obviamente sin concederle casi ni un segundo a la lectura del mensaje, lo toma como ofensa y difunde una campaña en redes sociales contra los premios Jaume I y la Generalitat Valenciana, cuando la campaña clarísimamente ha querido darle la vuelta a los tópicos y convertir la ciencia y la investigación en algo tan importante que sustituya esos tópicos. Pues finalmente, la organización ¡ha tenido que pedir públicamente perdón! Esto sucede porque el ruido y la cantidad de inputs que recibe la gente hablando de un mismo tema en las redes crea un estado de opinión ficticio que puede perjudicar mucho a marcas como la de este ejemplo, pero no hay que olvidar que forma parte de lo que se tiene que tener en cuenta a la hora de hacer el trabajo creativo; el consumidor acepta todo lo que parezca relevante sea o no adecuado para la marca.

En el ámbito creativo, hay una serie de tendencias de marketing que están dominando, tales como:

1) La automatización del marketing y la programática. La analítica de datos es el poder de obtener la información relevante para conocer mejor al usuario y obtener mejores resultados (más ventas, mayor conversión, más tiempo en tu web, etc.) La difusión del mismo contenido en varios formatos y plataformas que evolucionan continuamente.

2) El marketing de pago, Adwords. Las empresas no solamente hacen campañas de comunicación y han de tener muy claro cuáles son sus keywords (claves) principales para lanzar un producto y lanzarlo en Google en una plataforma como Adwords. 
3) Emisiones en vivo, una de las tendencias más populares, para todos los dispositivos, a través de redes sociales tales como Facebook, LinkedIn, Twitter. Van al alza porque su característica de fugacidad hace que todo el mundo quiera opinar en ese mismo momento. Si has lanzado algo y has hecho una emisión en vivo, conocerás de inmediato, cómo es la reacción del público si lo has vehiculado en las redes sociales adecuadas. Es decir, información en streaming.

4) Influencers y afiliación. Un ejemplo, hace poco se podía ver una cola «alucinante» en la plaza del ayuntamiento de Valencia; niñas de 15 años con sus padres y con un libro en la mano, en la puerta de una librería. Se trataba de un libro de Mónica Morán, influencer de 18 años, que tiene 2 millones de seguidores y que salta a la «fama» a través de Musicaly, plataforma de karaoke. Sus karaokes se diferencian en la manera de editarlos, consiguiendo un sello «personal», pero son exactamente eso, karaokes... No se le conoce ningún otro conocimiento ni valor que comparta con sus 2 millones de followers.

5) El ead nurturing. Se trata de alimentar permanentemente a los clientes potenciales, proporcionándoles los contenidos que desean y esperan, manteniéndose vivo el interés del cliente durante todo un proceso de la compra (búsqueda, evaluación y aceptación) y, finalmente, se consigue la conversión que se buscaba (es decir, la compra).

6) La búsqueda por voz debe contemplarse ya en las estrategias de marketing en buscadores que toda marca emprenda. La utilización del pódcast, la gran ventaja del audio, es su fácil digestión. Permite su consumo de manera simultánea a la realización de otras tareas. Se prevé un auge de los pódcasts y del audio online, un terreno lleno de oportunidades, pero poco o nada explorado todavía. Un ejemplo exitoso es el pódcast de la marca Fisher Price, El sonajero, en la plataforma Podium Podcast, con consejos, charlas y juegos para padres y juegos para niños. 
El uso de nuevas tecnologías nos proporciona nuevas estrategias, nuevas contenidos, nuevas herramientas para la comunicación...

Y nuevos actores en el sector.

El ámbito de acceso laboral a la comunicación publicitaria se ha ampliado, apareciendo nuevos departamentos de comunicación en empresas que tradicionalmente no contaban con ellos, como las centrales de compras o medios que han modificado sus estructuras y han creado departamento creativos, así como estratégicos, un tipo de estructura que era propio de las agencias de publicidad. Asimismo, la última aparición en el sector de la comunicación de las grandes consultoras como KPGM, Accenture, etc., que ya trabajaban para grandes clientes en auditorías y planes de negocio, adquiriendo un gran conocimiento de estas empresas, y que buscando una nueva línea de negocio pasan también a ser consultores de comunicación. Nuestro sector critica la entrada de consultoras, ya que a la hora de crear, las consultoras no tienen la experiencia de las agencias. Pero hay que considerar que es una opción laboral más, ya que el departamento de planificación, creativo o comunicación de estas empresas, que son muchas y muy grandes, contratan publicitarios, planners y creativos publicitarios.

En el lado del anunciante, los departamentos de marketing de las empresas han perdido valor y esta devaluación nos perjudica, como publicitarios y como creativos. Aún así, el marketing no ha muerto ni va a morir, hay que reinventarlo.

¿Qué ha pasado en las agencias?

Se ha producido una ampliación de perfiles; la incorporación de un montón de agentes externos. Un claro ejemplo es McCann. El grupo McCann se dedica a la estrategia y creatividad y además tienen varias empresas satélites que son los agentes externos que están dentro del propio grupo: Mrm Digital, Momentum, Future Brand, McCann Health, CRAFT Worldwide, Universal McCann, y Weber Shandwick. Esto ha hecho cambiar el perfil de la propia agencia.

El ámbito de la creatividad está influido por las transformaciones de los roles creativos, la incorporación de la cultura digital, la creatividad de contenidos o marketing de contenidos y la colectividad de equipos. 
Antes la estructura del departamento creativo era absolutamente piramidal, con el director creativo en la cúspide. Esta rígida estructura aún existe, pero está en vías de extinción. La creatividad tiende a ser hoy horizontal y transversal, y así deben asumirlo las personas que vayan a integrar los departamentos creativos y de comunicación de agencias o anunciantes. La tendencia es que no haya puestos fijos, seas lo que seas, serás creativo, o creativo tecnológico, o copy o arte para formar parte de «proyectos». Habrá un o una responsable de esos proyectos y alrededor del mismo se conformará el equipo, no por nominación sino por necesidades. El espíritu y el trabajo en equipo se refuerza. El proyecto manda en la colocación de las figuras que trabajan alrededor del mismo. El valor de las ideas tiene que ser tangible y los creativos deben salir del exclusivo terreno creativo abstracto a través de esa transversalidad. Se trata de complementar desde la transversalidad, porque somos una estructura holística y global.

¿Como se está implementando esa transversalidad?

A través de diferentes aspectos. La orientación al negocio no implica que los creativos tengan que aprender de otras disciplinas como finanzas y economía. Pero a diferencia de los tiempos en los que el resultado final económico de la campaña importaba, aunque no en exceso, para el trabajo creativo, actualmente hay una exigencia para los creativos en cuanto que conozcan en qué consiste el negocio de su cliente y que tengan su mira puesta en el rendimiento y la obtención de beneficio.

Otros ámbitos de implementación son la Innovación, el joint venture, realizar proyectos conjuntamente con el cliente, no solo de comunicación, sino también de estrategia, de trabajo colaborativo. Los equipos role opened compartidos por agencia y cliente convertidos en partners

Podemos observar este tipo de actividad en plataformas como Kickstarter, una plataforma donde hay que bucear permanentemente «haciendo realidad proyectos creativos». Se comparten ideas creativas de todo tipo, se plantean proyectos conjuntamente con marcas, proyectos individuales, audiovisuales, piezas gráficas, ilustración... es una fuente de información para saber lo que esta pasando y proponer al cliente. 
¿Qué cambios se han producido en el proceso creativo y en sus perfiles?

La tecnología digital pone en cuestión el concepto de campaña tradicional. La comunicación con el usuario es permanente y continúa. Como marca tengo la oportunidad de saber lo que piensa el usuario, la monitorización, los comentarios, todo lo que pasa en las redes, en lo digital. El cambio de actitud de las marcas que escuchan, rectifican y remodelan, algo que es muy importante para el proceso creativo, lo convierte en un proceso que no está cerrado, que puede seguir evolucionando, puede retocarse, modificarse según la reacción de los públicos.

La unidireccionalidad y el coste de difusión de las campañas convencionales pierden su sentido. Como indican Smith y Perlado «Grandes ideas que se convertirán en «largas ideas que circulen vivas en el ámbito digital».

¿Qué modificaciones se han producido en las estructuras de los equipos creativos?

En cuanto a los equipos y sus perfiles, no puede decirse que la dupla creativa convencional esté obsoleta. En el entorno digital, el equipo se forma alrededor del proyecto, no hay equipos estandarizados, uno ya no es copy para toda la vida. No hay modelo de equipo creativo, lo cual no invalida lo que había, lo que sí hay es una necesidad de contar con todos los avances.

Ogilvy ha contratado al músico Carlos Jean para desarrollar un área de trabajo que diseña estrategias de sonido, «Sony branding», así como sonorización de espacios para las marcas. La agencia ha abierto su estructura y eso tiene que ver con la creatividad; es un integrante más del equipo creativo.

Los nuevos roles, las nuevas figuras que ya están aquí:

1) Creativo Tecnológico, experto en formatos de nuevas tecnologías y fanáticos de la informática.

2) Programador. No es preciso que los creativos programen, pero necesitan trabajar con ellos. Si se diseñan acciones que requieren una aplicación, se necesita que intervengan programadores, porque 
constatarán que el proyecto es viable. Si el contenido es muy interesante y la aplicación no funciona el fallo es tremendo, la programación ha de solucionarlo, son especialistas tecnológicos.

3) Arquitecto de datos o información. Controla la interacción del usuario a través de plataformas y canales, puesto que es preciso que haya un seguimiento y una necesidad de prever los posibles recorridos que va a tener la acción, y que va a llevar a cabo el usuario. Sé lo que es y sé lo que le podría pedir, pero se podría decir: ¿Tienes datos para contarme cómo se va a mover esto? Porque es impensable la petición, que muchos clientes hacen: «hazme un vídeo viral». Podrás realizar un vídeo, pero la viralidad es obvio que la maneja el usuario online.

4) Una figura muy interesante es el user experience designer y está adquiriendo mucha importancia. Su rol es no solo prever los recorridos, sino trabajar la variable cualitativa, modulando la intensidad de las experiencias de contacto incluso más allá de lo digital.

5) El director técnico de producción, un perfil que es más o menos el mismo que el del creativo tecnológico. Se le asigna una función a mitad de camino entre la creatividad y la producción. Aunque la producción digital se ha externalizado como consecuencia del desarrollo y sofisticación de la publicidad digital, mucha producción se hacía in-house, pero en la actualidad, si se pretende un buen estándar de producción, hay que acudir a los especialistas y estos están en las productoras digitales externas.

¿Los creativos pueden aprender a amar la tecnología?

Antes el proceso era más sencillo, aunque no por ello menos complejo. Está claro que la introducción de la tecnología en nuestra profesión afecta, pero hay mucha gente en el sector de las agencias que son sénior: creativos sénior, directores de arte sénior, etc. que tienen mucho talento y que lo han demostrado en todas las facetas del proceso

¿Cómo evolucionar? ¿Qué se debería hacer? ¿Cómo lo planteamos para que todos tengan cabida? 
La respuesta es llevarlo a un enfoque consultivo, como las consultoras. Conocer el negocio del cliente, plantear proyectos de innovación, no solo en la comunicación sino en el producto, utilizar los productos que tiene la marca para una acción de comunicación. Hay que acercarse a lo que las empresas quieren, no hay otra manera de hacerlo. Y ser versátiles, movibles, estructuras líquidas y adaptables a los proyectos.

Un ejemplo de buena praxis en este sentido sería el corto patrocinado por Samsung, Relato de un fotógrafo de guerra, que trata sobre la comparación del trabajo como fotógrafo de guerra del autor con la «guerra» que tienen las mujeres con el cáncer de mama. Es una pieza audiovisual impecable, que además lleva a cabo una acción de RSC (responsabilidad social corporativa), una iniciativa solidaria de Samsung en colaboración con la Federación Española de Cáncer de Mama (FECMA) y la Sociedad Española de Oncología Médica (SEOM). Un proyecto en beneficio del usuario. Se trata de detectar un mercado concreto, una necesidad concreta y darle voz.

Cheil, la agencia de Samsung en todo el mundo, fundamenta su trabajo como agencia de comunicación y estrategia en un planteamiento conjunto de creatividad, innovación y tecnología. Realizan múltiples campañas planteando nuevos usos para los productos de la compañía, como es el caso del proyecto Dytective: una aplicación que detecta el riesgo de dislexia en quince minutos; que proporciona un beneficio y eleva el valor de la tableta Samsung. Como explica su claim de campaña «Tecnología con compromiso». Creatividad y comunicación aplicada a la innovación tecnológica.

También es muy interesante la utilización que han hecho de los medios que siempre han sido convencionales y que han evolucionado con aplicaciones tecnológicas, como la acción Parkour Screens que desarrollaron en la Plaza de Callao de Madrid para promocionar las nuevas pantallas Samsung.

La característica de transversalidad de la creatividad y sus aplicaciones transciende al ámbito online y las innovaciones tecnológicas llegan a un medio tan estático como es el de la publicidad exterior. Una reciente campaña de la agencia valenciana Siberia convirtió las marquesinas de 
autobuses en receptores de llamadas telefónicas en directo, destinadas a ofrecer trabajo a los mayores de 55 años. Acción del Ayuntamiento de Valencia dirigida a un colectivo con muchos problemas para acceder al mercado de trabajo. El éxito de la acción se completó con su viralidad en redes sociales.

¿Pero ante tanta tecnología, dónde queda el talento y dónde queda la emoción?

Aquí hay que reivindicar el principal objetivo de la creatividad; crear emociones. A pesar de esta revolución tecnológica, de las distintas formas de trabajar, de la nueva formación que precisaremos para saber comunicar, por encima de cualquier plataforma digital estamos nosotros, los usuarios, y nos seguirán interesando mensajes que no solo nos impacten por lo tecnológico sino por el lado al que nunca renunciaremos, el lado humano, la EMOCIÓN con mayúsculas.

Los creativos deben ser buenos comunicadores y manejar las herramientas de la cultura digital en las que hoy en día es imposible no moverse, pero sobre todo tienen que saber interpretar esa cultura digital. Por ejemplo, el tan traído big data, que asusta nada más oírlo, la analítica de datos que proporciona mucha información, es incuestionable, pero si los datos obtenidos no se reinterpretan, sino se reconvierten en intereses que tienen los usuarios, los receptores cansados desestimarán el mensaje, no interesará a la audiencia.

El talento y la emoción, que son intemporales, que superan tendencias, modas e inventos, que superan nuevas situaciones y nuevos escenarios, que reivindican «la vida misma». Un ejemplo es la campaña de Volkswagen, La vida loca, no es una campaña antipatinetes, ni antimillenials ni antiselfistas. Y que cierra con un magistral mensaje «¿A qué jugamos?», para llegar a recuperar la emoción del producto, de la marca.

En definitiva, y refiriendo una frase de Mónica Moro (directora creativa ejecutiva de Mcann), «Más que creativos somos creadores, expertos en negocios, en aportar y hacer crecer a nuestros clientes». Se expresa diciendo que quiere trabajar en la cadena de innovación de producto. Que sus clientes confíen en que pueden hacer propuestas de innovación 
que derivarán en propuestas de comunicación. Nuevo enfoque del rol estratégico y creativo.

La creatividad es transversal, salgamos de los egos creativos. Las ideas no son de nadie, son del equipo. No necesitas tener el título de arquitecto de la información, de analítico, de using designer, necesitas saber que todas esas figuras existen y tú puedes encajar en ese nuevo grupo de trabajo, en esta nueva forma de trabajar. La tecnología y la creatividad; la búsqueda de la simbiosis perfecta.

Para finalizar, hay que reivindicar la figura de la mujer en nuestro sector. Las mujeres llevan muchos años sufriendo situaciones muy ofensivas y discriminatorias dentro del ámbito publicitario. En este sentido, es esperanzador que surjan plataformas como Mujeres Creativas, y alentador que triunfen sobre todo entre los más jóvenes. Es una plataforma abierta a todo el mundo sin discriminación de género. Mujeres Creativas ha creado un premio, «Mujeres a Seguir», donde se evidencia el papel tan importante que han tenido las mujeres en el terreno creativo publicitario en España así como en el internacional.

Y como cierre, destacar y agradecer al festival publicitario del sector en la Comunidad Valenciana, La Lluna, porque tendrá el primer jurado de un certamen publicitario en España integrado al completo por mujeres profesionales de mucho nivel. Y un dato de cierre «En las universidades valencianas hay un $70 \%$ de mujeres, mientras que en las empresas solo el $11 \%$ está en el departamento de creatividad y solo el $2 \%$ en puestos directivos» (Marta Chillarón, jurado de La Lluna, 2018).

Creativos y creativas publicitarios, comunicadores, grandes profesionales, la creatividad no es perrogativa de nadie y mucho menos relacionada con el género, igual que ha de ser transversal, es universal, es un potencial del ser humano, solo tenemos que adaptarnos a esta evolución. 


\section{NEUROMARKETING Y PUBLICIDAD: \\ ANÁLISIS DE CASOS PRÁCTICOS \\ EMPLEANDO \\ EL ELECTROENCEFALOGRAMA, \\ RESPUESTA DERMOELÉCTRICA, \\ EXPRESIÓN FACIAL IMPLÍCITA, \\ EYE-TRACKING Y OTRAS VARIABLES*}

Ubaldo Cuesta

Universidad Complutense de Madrid

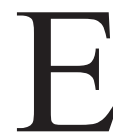

STA CONFERENCIA SE VA A CENTRAR, parcialmente, en el neuromarketing que hacemos desde la Universidad Complutense, en el laboratorio denominado Neurolab Center (https://neurolabcenter.com/).

Habréis oído hablar mucho de neuromarketing y quizá no siempre con acierto porque hay como dos tipos de neuromarketing: uno que es, en gran medida, «vender humo» y se centra en hablar de cómo entrar en el cerebro del consumidor y ese tipo de cosas que, en realidad, no describen con rigor en qué consiste el neuromarketing. Este enfoque ha hecho daño al sector porque ahora hay clientes, agencias, consultoras y otros interlocutores del sector que no confían en el neuromarketing científico. Yo intentaré hablaros aquí del neuromarketing basado en conocimientos científicos derivados de diferentes áreas de conocimiento, el cual, si es aplicado con rigor, proporciona importantes ayudas a la investigación en neurocomunicación y marketing aplicado. Es el que intentamos hacer desde el laboratorio de neurocomunicación en el Departamento de Teoría y Análisis de la Comunicación en la Universidad Complutense de Madrid.

En este laboratorio tenemos, por una parte, lo que está viendo el sujeto, por ejemplo, un anuncio de publicidad y esto, a la vez, lo puede

* Ponencia transcrita íntegramente a partir de su exposición, por lo tanto, el texto se ajusta más al estilo oral que al escrito. 
ver el investigador, con una serie de variables, de registros, puede observar la cara del sujeto, elelectroencefalograma, el eye tracking (dirección de la mirada, tamaño de la pupila, mapas de calor, frecuencia de parpadeo, proximidad al estímulo), etc.

El denominado eye tracker registra la mirada del sujeto. También tenemos en el laboratorio un electroencefalograma, una webcam que es una cámara que está grabando al sujeto para analizar las emociones de su cara junto con un aparato que mide las respuestas eléctricas de la piel (la respuesta galvánica de la piel, GSR en inglés). Y todo eso lo integramos con los estímulos, con la publicidad o la película o el estímulo que sea que está viendo el sujeto.

Estos son los principales elementos que estamos testando, que estamos analizando, que os voy a intentar describir rápidamente a continuación uno por uno.

¿Por qué surge el neuromarketing? Entre otros motivos, porque hay una gran diferencia entre lo que las personas dicen y lo que piensan, y lo que de verdad sienten. En ocasiones, por no decir lo políticamente incorrecto, pero en otras ocasiones porque ellos mismos no conocen bien lo que sienten o cómo valoran una situación: son las llamadas «respuestas implícitas», es decir, automatizadas o parcialmente no conscientes. Con la aplicación de la neurociencia podemos acceder a un nivel de información hasta ahora desconocido porque hasta ahora nos basábamos en lo que los sujetos nos decían mediante encuestas, focus groups, entrevistas en profundidad, etc. En cambio, ahora con el neuromarketing podemos aproximarnos mucho mejor a lo que realmente siente el sujeto, lo que está sintiendo «su cuerpo», por así decir.

Para explicarlo de forma sencilla: esta técnica funciona porque el ser humano básicamente está haciendo siempre en su vida dos cosas; intentando ser feliz e intentando huir de las cosas negativas. Es como si el organismo se comportara sobre su entorno con códigos que van entre ceros y unos: intentamos acercarnos a lo que nos gusta y evitar lo que nos desagrada. A esto le llamamos desde el punto de vista psíquicofisiológico, (es decir, aquello que une la fisiología con la psicología), 
respuestas de orientación (atracción) y respuestas de defensa o de huida (rechazo).

El organismo funciona como un todo, cada vez que a mí me parece algo agradable, (por ejemplo, comida si tengo hambre), mi organismo responde como un todo, mi cerebro genera un cierto tipo de ondas, mis pupilas se dilatan, mis músculos se preparan para actuar para acercarme, etc. A este proceso lo denominamos patrón de respuestas de orientación. Por ejemplo, si algo no me agrada hay respuestas de defensa: si algo me desagrada, el corazón se acelera, los músculos se contraen, la respuesta galvánica de la piel se altera...

Esto es, a grandes rasgos a lo que se dedica el neuromarketing, en cuanto neurociencia aplicada a la comunicación comercial: a registrar estos cambios del organismo (cambios psicofísicos) que se producen frente a determinados estímulos (un anuncio, un logotipo, etc.).

Podría definirse desde estos dos grandes aspectos:

1) La aplicación de los conocimientos de la neuropsicología a la comprensión del ser humano: ahora sabemos mucho de neuropsicología, zonas del cerebro, cómo funcionan, de qué manera, cómo actúan con el organismo, etc., y todo eso lo podemos aplicar a la comunicación.

2) El empleo de nuevas herramientas de investigación de hardware y software: la tecnología se ha revolucionado tanto que ahora tenemos un aparato pequeño que me permite ver cómo está reaccionando mi piel, o una cámara muy pequeña que me puede grabar el rostro y saber si estoy contento, triste, enfadado o alegre. Y, además de tener este hardware, ahora tenemos un software que integra todo eso y me da una medida y me dice con toda precisión, por ejemplo, si este sujeto al ver determinado anuncio, estaba alegre, su corazón se aceleró, su piel se activó como consecuencia del mensaje que ha recibido y, además, aparecieron ondas alfa más activas en su cerebro junto con una asimetría prefrontal de ondas beta y todo eso integrado con un software muy preciso y relativamente simple. 
Los conocimientos de la neuropsicología implican conocer cómo funciona el cerebro, entendiendo por el cerebro sistema nervioso central y periférico, desde el punto de vista neuroanatómico y sistema autónomo y sensitivo, desde el punto de vista funcional. El cerebro, de forma voluntaria, pero también de forma autónoma (automática, sin participación de mi voluntad) es el que controla todos mis músculos, mi estómago, los tendones, los gestos..., el que me permite detectar mediante un electromiograma, por ejemplo, si un sujeto está mostrando atención porque sus músculos se tensan o si algo le agrada porque hay asimetría frontal de ondas gama.

Para trabajar en este campo es necesario conocer las estructuras anatómicas del cerebro humano. El cerebro es muy complejo, pues no solamente es saber cuestiones como que el área occipital del cerebro participa activamente en controlar la visión, sino que esa visión además está unida con el tálamo, y además está muy unida con la retina, con el nervio óptico, con las señales de input que entran y con las señales de output que generan el movimiento y que hacen que la pupila se dilate, etc. Esa es la estructura funcional y, naturalmente, enlazar todo eso con los resultados finales a nivel cognitivo, emocional y conductual (qué es lo que pienso a nivel cognitivo sobre ese estímulo, qué es lo que siento, cuáles son mis emociones y cómo voy a actuar o cómo estoy actuando). En eso consiste la neuropsicología, en integrar esas tres áreas: la anatomía, las estructuras funcionales y los resultados de esta integración en términos cognitivos, evaluativos y comportamentales.

Por ejemplo, el cerebro está dividido en áreas: el área frontal, occipital, temporal y parietal, pero a su vez tenemos que saber que estas áreas cumplen distintas funciones complejamente entretejidas entre sí. Por ejemplo, estas son las áreas del lenguaje, que son las que tiene que activar si yo le hago un registro electroencefalográfico o mediante una tomografía computerizada, son las que se activan cuando el sujeto empieza a leer. También están las áreas prefrontales, que con un electroencefalograma se detectan con el punto F2 y F3, y son las que se activan cuando el sujeto va a tomar una decisión cognitiva. Y luego están las áreas de los ganglios 
de la base, muy comprometidos con las emociones (ira, miedo, atracción, placer) y muy cerca se encuentra el cerebelo y la sustancia nigra, que son los que controlan, en parte, el movimiento. Dentro tenemos el famoso sistema límbico o sistema rinencefálico a veces llamado sistema reptiloide, que es la parte profunda del cerebro que controla las emociones más concretamente la famosa amígdala, muy utilizada en comunicación ya que es la estructura que controla los centros de placer y de temor, como el sexo o como la ira.

También está dentro del sistema límbico la amígdala, conectada con el hipotálamo y el hipocampo, que es la gran estructura del sistema límbico que conecta con el recuerdo, el reconocimiento y, por lo tanto, todo lo que tiene que ver en publicidad y con el impacto, la notoriedad, etc.

Pero no solo tenemos que saber del cerebro, esto es una estructura de cómo es nuestra piel, dónde tenemos el vello de la piel, las glándulas sebáceas, etc.

Tenemos que conocer también cómo funciona la piel como parte del sistema cerebral del sistema periférico. La piel, a nivel del desarrollo embriológico, surge de la misma estructura que el cerebro, está muy conectada con el cerebro, por eso cuando alguien tiene nervios le pueden salir ronchones o cuando tiene alergia, por eso en cuanto uno se pone nervioso la temperatura de la piel disminuye o aumenta, de ahí el que podamos utilizar la medida de la respuesta dermoeléctrica para saber si una persona está excitada o no, si ese anuncio le ha generado impacto, que es una forma de medir la atención.

En la actualidad, el neuromarketing no mide únicamente la respuesta de la piel, sino de la pupila, de las expresiones faciales, de la saliva, etc. Ahora se utilizan mucho medidas salivares para saber si un sujeto está prestando atención, si está emocionado, si le está gustando ese estímulo, etc.

Tenemos un aparato que nos permite medir en una persona si su conductividad eléctrica ha aumentado o ha disminuido. Con este aparatito tan pequeño que conectamos por bluetooth al ordenador, podemos saber si esta piel se ha activado o no y medir la variable que llamamos 
«respuesta dermoeléctrica», que es una de las variables más precisas para determinar si un sujeto está emocionado o no.

La respuesta dermoeléctrica tiene dos niveles: La respuesta fásica y la respuesta tónica. La fásica es la línea base, cómo está mi piel en condiciones normales a nivel de la conductividad. Mientras que la tónica es la que ocurre cuando aparece un estímulo. Por ejemplo, proyectamos ante un sujeto dos estímulos, uno en un sitio y otro en otro. La diferencia que se produce desde que entra el estímulo hasta que sale genera un pequeño incremento, lo que llamamos un «pico» y podemos medir su amplitud de tal manera que el ordenador me puede definir perfectamente en qué momento exacto aparece el estímulo. Imaginaos un anuncio de treinta segundos justo cuando aparece la chica guapa o el chico guapo, cuatro segundos después aparece un pico, dos o tres o cinco dependiendo de la intensidad del estímulo.

Por lo tanto, estamos midiendo respuestas implícitas del organismo. Este está emitiendo constantemente en este patrón de respuestas que antes os llamaba respuestas de orientación o de defensa y está emitiendo constantemente respuestas, y lo que hacemos con el neuromarketing es medirlas con aparatos muy científicos y muy precisos como éste que nos permiten asignar números a los fenómenos cognitivos y estudiarlos.

El neuromarketing se puede utilizar para hacer un pre test de una película terminada, para analizar un packaging, para analizar un expositor, hacia qué partes mira el sujeto y cuándo se emociona su cuerpo más o menos en función de la parte del expositor que está mirando, para estudiar la reacción del sujeto ante un nuevo diseño visual, etc. En resumen, es una ciencia que aporta y ayuda a que la publicidad y la comunicación puedan ser más efectiva.

Por ejemplo, tenemos una persona que está mirando un anuncio y podemos analizar gracias al eye tracking qué ha mirado primero, si el logotipo, luego el objeto publicitado, los protagonistas del anuncio, el eslogan, etc. Y, además, nos indica el tiempo que ha estado mirando a cada uno de los componentes del anuncio y su recorrido visual.

A su vez, podemos obtener otros datos de interés. Por ejemplo, tenemos dos hemisferios, el izquierdo y el derecho. Simplemente conectamos 
dos pequeños electrodos en esta parte en el área prefrontal, la que antes os dije que medía aspectos cognitivos. Sí el hemisferio izquierdo está un poco más activo, hay un incremento de actividad en el izquierdo, y eso significa que el sujeto está mirando algo que le gusta, que le genera sentimientos positivos. Por el contrario, si está más activo el derecho está mirando algo negativo y se quiere ir, ese estímulo no le gusta.

Y este aspecto lo analizamos con tablas y gráficos con datos que nos proporcionan información detalla por cada segundo.

Es importante resaltar que no debemos confundir neuromarketing con el psicoanálisis (inconsciente). Nosotros no estudiamos el inconsciente, que es un paradigma que en la academia no está considerado científico desde el momento que no emplea el método científico inductivo-hipotéticodeductivo. Nosotros hablamos de respuestas automáticas implícitas que el propio sujeto no sabe que está emitiendo, pero lo está haciendo de manera espontánea, automatizada.

Lo que intentamos hacer en el neuromarketing es integrar todas estas variables psicofisiológicas, integrarlas para tomar una medida conjunta de todo lo que está diciendo el cuerpo en ese momento, cuando está viendo ese estímulo de tal manera que vamos a medir a la vez el electroencefalograma, las respuestas de la asimetría frontal pero también otras. Por ejemplo, sabemos que cuando alguien presta mucha atención visual a algo, las ondas alfa occipitales se activan, el electroencefalograma, el eye tracking nos permite ver hacia qué punto concreto está mirando y de qué manera y cuánto tiempo y se ha vuelto o no a mirar al mismo sitio, si me quedo mucho tiempo mirándolo también medimos el nivel de atención, pero una atención diferente: quizá no he comprendido el estímulo y por eso le dedico más tiempo, lo que no significa que me guste, significa que ha captado mi atención visual probablemente para intentar decodificarlo. Pero si luego no vuelvo al estímulo eso es que no me ha interesado en exceso, he perdido tiempo en decodificarlo y no vuelvo a él.

Después tenemos medidas de expresión facial, medidas de la frecuencia cardiaca, la aceleración cardiaca, de la cual podemos medir cuestiones como la llamada variabilidad intercardiaca la cual nos indica no solo el 
número de pulsaciones por minuto sino cómo son de constantes, lo cual correlaciona mucho con la relajación o la ansiedad. De hecho la variabilidad intercardiaca la usan los deportistas de élite para aprender a relajarse.

También tenemos medidas electromiográficas, como la tensión muscular, el electromiograma es el que mide la electricidad de los músculos, el GSR y otras.

Además, el sistema API es un programa informático conectado a todo nuestro sistema que permite incluir otras variables como, por ejemplo, la respiración, para evaluar si respiro agitado o sereno y la amplitud de la respiración. Por ejemplo, un sujeto está mirando un coche en un anuncio y estamos registrando todas estas variables anteriormente comentada, que las estamos midiendo a la vez y las estamos integrando justo con lo que está mirando, y además estamos haciendo un eye tracking sobre qué partes está mirando del producto y, además de todo esto, podemos obtener datos agregados, no solamente individuales, sino que podemos agregarlos y juntar hombres y mujeres y decir, por ejemplo, ¿cuál es la diferencia entre hombre y mujeres? o bien: ¿Han mirado sitios distintos?

También tenemos en el laboratorio unas gafas que se pone el sujeto para realizar eye tracking móvil. Así, por ejemplo, el sujeto se desplaza por una gran superficie de alimentación tipo El Corte Inglés o en una exposición de coches y podemos analizar dónde mira el sujeto mientras está en movimiento, grabar los registros visuales, calcular mapas de calor, tiempos de fijación, etc. Este sujeto en concreto llevaría las eye glasses. que a su vez, incorporan el electroencefalograma y el GSR. Todo eso está conectado a un ordenador portátil que lleva en una pequeña mochila, y está enviando las señales al ordenador y nosotros, desde una mesa que está al lado, estamos grabando todo esto, a dónde mira, puntos de fijación y variables que se están registrando en función de los sitios a los que mira, las respuestas dermoeléctricas y el electroencefalograma.

Algunas de las variables más importantes son los rayos que se disparan a mi pupila, ya que se produce un efecto de refracción y me permiten ver rutas visuales. Las chicas hacéis rutas visuales diferentes a los chicos, casi siempre. De cada sujeto medimos el denominado time total spend, 
tiempo total mirando un sitio, número de veces que he ido con la mirada y he vuelto, número de parpadeos, que se correlacionan mucho con la atención (cuanto más te interesa un estímulo menos parpadeas) y otras variables.

También la dilatación de la pupila proporciona datos muy interesantes: cuanto más te gusta un estímulo, más se dilata la pupila. También registramos las expresiones faciales, registramos una gran variedad de músculos y el propio ordenador, al analizar los «paquetes musculares» que se han activado, realiza complejos cálculos estadísticos basados en expresiones faciales acumuladas en su base de datos y te dice: aquí apareció alegría, aquí tristeza... y te lo puede decir en porcentaje o mediante otras fórmulas similares. Así, por ejemplo, podemos pedirle el número de sonrisas que han aparecido en las chicas ante un estímulo concreto respecto a los chicos. Y no solo podemos agrupar la información por género, sino también por edad del sujeto estudiado, clase social, etc. A veces usamos tipologías del consumidor muy ilustrativas: consumidores más clásicos frente a consumidores urbanos y en base a eso nos salen diferencias en el eye tracking.

El electroencefalograma es muy complejo: permite calcular desde asimetría prefrontal de ondas gamma o beta hasta actividad de las ondas alfa en el occipital o calcular ondas betas centrales por ejemplo.

El aparato conocido como shimmer que empleamos, mide la respuesta dermoeléctrica de la piel (GSR), pero también podemos medir la temperatura de la piel y el electromiograma muscular que me permite ver el interés que está dedicando el sujeto ante un estímulo, en función de la tensión generada en determinados paquetes musculares.

Siempre tenemos que integrar todas estas medidas; tenemos que analizar todas las medidas a la vez para poder entender qué es lo que está ocurriendo realmente justo en el momento en que los sujetos perciben los estímulos. Por ejemplo, si yo tengo un sujeto que me da muy alto en GSR sé que tiene un ítem emocional alto, se ha emocionado, pero no sé si a positivo o negativo, con valencia positiva o negativa, porque a mí me puede parecer de una manera distinta a la realidad percibida por el sujeto. Pero si lo triangulo con la expresión facial y compruebo que 
junto con el GSR ha demostrado sonrisa y alegría es que el ítem es positivo. Luego lo enlazo con su expresión facial y si además lo triangulo con el eye tracking sé que además ha habido atención visual de ese estímulo y qué punto concreto ha generado esta atención. Solo con estas tres variables; eye tracking, facial emotion y GSR puedo obtener con precisión dónde miraba, cuánto le gustaba, con qué intensidad y si era de agrado o desagrado.

Para medir emociones, interés, agrado, intención de compra, etc., por supuesto que seguimos utilizando las formas clásicas, por así decir. Por ejemplo, cuando le presento a un sujeto un packaging de un producto cualquiera, además de analizarle con las técnicas del neuromarketing también le pregunto: «De 0 a 10 ¿te gusta este packaging?» Esto lo seguimos haciendo junto con el neuromarketing, además de realizar también focus groups, entrevistas en profundidad, etc. Que en la actualidad existan nuevas formas no implica que desaparezcan las tradicionales.

De esta manera, nos encontramos con que conviven variables clásicas con variables nuevas a la hora de evaluar diferentes aspectos de los procesos cognitivos y emocionales. Las variables más importantes, clásicas, en publicidad son estas que aparecen en la gráfica: atención, emoción, memoria y atracción o deseo, pues la atención la podemos medir con la típica escala de atracción. Pero también podemos ahora mirarlo con el porcentaje de fijaciones válidas, cuántas veces ha vuelto la mirada, hacia qué estímulo en concreto, nivel de aceleración o con desaceleración cardiaca, etc.

La emoción, por supuesto, es muy importante en la comunicación publicitaria. Por ejemplo, les preguntamos mediante un cuestionario: «¿Te has emocionado? De 0 a 10 », pero lo puedo medir también con el GSR, midiendo la emoción también con la variabilidad cardiaca. HRV significa heart rate variability, variable muy típica del neuromarketing.

El test automático de medida de tiempos, es una medida que usamos también mucho en neuromarketing: cuánto tiempo tarda un sujeto en responder a algo; si tarda mucho en responder, es porque eso le ha generado cierta tensión. El aparato mide el número de inspiraciones y lo relaciona con la asimetría frontal que os expliqué anteriormente: si el 
hemisferio izquierdo está más activo que el derecho es que eso le está generando emoción.

La memoria, por supuesto, también se mide mediante un test clásico de reconocimiento, pero también usamos el IAT de memoria implícita o puedo usar la activación del hipocampo, que no se puede medir en nuestro laboratorio porque para ello hace falta una máquina grande en la cual metes al sujeto y le haces una tomografía computerizada que en realidad lo que mide es el flujo de sangre en esa estructura.

La atracción también se mide mediante una escala: cuánto te gusta, esto cuánto te atrae, la intención de compra de un producto o servicio publicitado, etc. También podemos medir la dilatación pupilar que os contaba antes con la anécdota del chico o la chica que te gusta, es clarísima, la pupila rápidamente se dilata cuando algo te gusta.

Voy a explicaros algunos ejemplos de lo que hacemos en nuestro laboratorio:

En este estudio cogemos un grupo de sujetos y les hacemos un pre test emocional al entrar: «¿Cómo te encuentras de feliz en este momento de 0 a 10?». Rellena un cuestionario y, a continuación, a la mitad de la clase les presento un vídeo de noventa segundos positivo y a la otra mitad un vídeo de noventa segundos negativo y ahí tomamos esas medidas psicofisiológicas y después hacemos un post test a la salida: «¿Cómo te encuentras de feliz?». En cuanto a los resultados de este caso: el vídeo negativo (donde había escenas de mujeres gritando) tenemos resultados en concreto del eye tracking, la pupila va cayendo y de pronto en un estímulo muy fuerte la pupila se dilata, porque la pupila también se puede dilatar por algo desagradable al igual que por algo agradable. En este caso, tenemos muchos «picos de datos» y de pronto baja porque no está pasando nada y de pronto empiezan a subir, es decir, en estos momentos el sujeto estuvo muy activo y dentro de este parámetro tenemos, por un lado, el tamaño de la pupila y, por otro lado, la distancia. De tal manera que tenemos la película y podemos ir viendo todas esas variables del sujeto, cómo se está comportando en cada momento, podemos ver una medida de la asimetría, las ondas y la diferencia entre el hemisferio derecho y el hemisferio izquierdo. Cuando vieron la película positiva 
salieron más contentos, cuando vieron la película negativa salieron más tristes, y este fenómeno fue más marcado en hombres que en mujeres, algo que también es frecuente, que normalmente los hombres son más sensibles a estímulos externos que las mujeres. A esto lo llamamos efecto interacción: para unas cosas son más los chicos para otras más las chicas.

Otro experimento realizado por nosotros y que voy a describiros se desarrolló en el campo del denominado marketing sensorial, la aplicación del neuromarketing al marketing sensorial.

Se desarrolló del modo siguiente: tenemos tres perfumes; positivo, neutro y negativo. Podemos medir en el sujeto la asimetría frontal y vamos viendo cómo correlaciona una asimetría frontal positiva cuando le gusta el perfume y negativa cuando le ponemos el amoniaco. Esto es muy curioso porque lo que salió fue que con el negativo sale una especial atención y vinculación (engagement), que es una de las medidas de expresiones faciales, pero también aparece en los resultados una especie de rabia en contra de ese perfume. Es con el negativo donde se activa mucho y además se activa el disgusto. Estamos hablando de movimientos musculares implícitos, ya que estamos mirando al sujeto, y el ordenador me dice que ha mostrado alegría, sorpresa porque son movimientos imperceptibles, pequeños gestos que hacemos de sorpresa, de emoción...

Otro ejemplo de cómo analizar un spot: tenemos el spot A y en otro lado tendríamos el spot B, el típico spot que dura veinte segundos. En este caso tenemos los quince segundos iniciales y tenemos tres medidas y vamos viendo cómo a medida que avanza el spot van cambiando las curvas de tal manera que la interpretación global es que este spot tiene como tres partes: una primera parte donde empieza a caer esta variable pero luego a partir de un momento determinado del anuncio se incrementa, luego cae y a partir de otro momento en concreto se estabiliza. Esto es muy útil incluso para testar series de ficción ya que la serie de ficción a veces empieza con mucha emoción pero luego va decayendo. Por ejemplo, en la serie The Walking Dead el último capítulo empieza con mucha emoción, pero de pronto empieza a caerse y los sujetos empiezan a aburrirse entonces esto sirve incluso para hacer distintos 
montajes de películas y saber en qué momento tienes que quitar un elemento que no está generando atención.

También se usa para páginas web, esto es muy interesante porque proporciona un análisis visual que además te está detectando dónde mira más el usuario. A continuación les preguntamos por el recuerdo de todas las marcas posicionadas y nos coincide en que donde más han mirado es a donde más recuerdo de marca publicitaria ha habido.

Y por último, una de las últimas investigaciones que hemos hecho ha sido para una marca: Campofrío. Campofrío tenía interés en saber cuál de estos cuatro packaging sería el mejor. Son muy parecidos pero hay diferencias. Lo que hicimos fue un estudio de cómo los sujetos miran a diferentes partes del envase, la ruta visual y el cierre de la mirada. Es un estudio muy complejo con muchas variables (tenía como cuarenta páginas de gráficas). Simplemente quería explicaros algunas para que tengáis una idea de cómo se hacen estos estudios y cómo se pueden aplicar a la comunicación publicitaria de una marca.

Por lo tanto, y para concluir, la neurocomunicación es un universo lleno de posibilidades, podemos hacer montones de investigaciones desde nuevas perspectivas que nos permiten analizar fenómenos de comunicación muy interesantes. Por ejemplo, estamos investigando ahora en publicidad subliminal, una imagen que el sujeto no ve o dice que no ve pero su cerebro, sin embargo, reacciona a nivel del EEG. También lo estamos aplicando con la música: al mismo anuncio le pones una música, le pones otra, el sujeto dice que no nota apenas diferencia pero nosotros podemos decir que su cuerpo está reaccionando muy diferente en función de la música frente al mismo anuncio.

Estamos estudiando también ahora cuando la gente entra en un centro comercial, se ponen las gafas para saber a dónde mira, hacia qué puntos mira, etc. Esto sirve para emplazar muy bien los anuncios publicitarios en un espacio determinado. Hace poco estudiamos una gran marca que habían colocado una valla gigante a la entrada de la gran superficie y a los sujetos les poníamos las gafas cuando salían del coche y nadie miraba para la gran valla y era absolutamente objetivo. Es decir, que el neuromarketing, efectivamente, no sustituye a las técnicas anteriores de focus 
group, entrevistas en profundidad, etc., sino que las complementan. Pero lo más destacado es que nos permiten conocer de forma muy objetiva y con datos muy concretos y, además, nos aportan datos de variables que el sujeto no sabe que se están produciendo porque son variables implícitas y que ni siquiera él sabe que realmente existen.

Uniendo todo eso, podemos tomar decisiones muy importantes en investigación de mercados y, en concreto, podemos avanzar a la hora de investigar nuevos fenómenos y poder entender mejor cómo funciona la publicidad, cómo funciona la comunicación y cómo hacer cada vez mejores campañas persuasivas.

Muchas gracias por la atención. 


\section{COMPETENCIAS DIGITALES PARA UN CONSUMO SALUDABLE EN REDES*}

CARMEn Marta Lazo

Universidad de Zaragoza

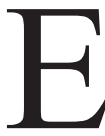

N ESTA INTERVENCIÓN, COMENZARÉ REALIZANDO UN diagnóstico contextual del consumo que ocupan los medios digitales en el tiempo de la ciudadanía. A continuación, hablaré del uso que se realiza de las redes sociales y del factor relacional como un nuevo constructo interesante en la nueva del conectivismo. Ahondaré en la importancia de la formación en competencias digitales para el uso saludable de las tecnologías. Y, por último, me detendré en el concepto de «habilidades para la vida» en el marco de cómo se pueden utilizar los nuevos medios en el sentido que marca la Organización Mundial de la Salud. También presentaré lo que hacemos en TRICLab, un laboratorio experimental en el que trabajamos todos estos temas en la Universidad de Zaragoza desde una vertiente basada en el humanismo digital.

El pulso de nuestra sociedad está condicionado por el pálpito de lo que ocurre en la red y, al mismo tiempo, lo que pasa en el mundo trasciende de forma inmediata a este gran contenedor de información. Si bien en épocas anteriores los medios de comunicación representaban unos canales por los que acceder de manera unidireccional a la información, hoy los social media, protagonizan todas las acciones de cada uno de nosotros. Si atendemos a lo que ocurre en internet en un minuto, nos encontramos con cifras sorprendentes. Por ejemplo, en 2018, cada minuto se producen 3,7 millones de búsquedas en Google, se ven 4,3 millones de vídeos en YouTube o se envían 481.000 tuits.

En las últimas décadas, la media de consumo de medios digitales (internet, televisión digital y videojuegos) ha crecido de manera exponencial. En contrapartida, el decrecimiento de los medios analógicos ha sido considerable.

* Ponencia transcrita íntegramente a partir de su exposición, por lo tanto, el texto se ajusta más al estilo oral que al escrito. 
Según datos de Statista de septiembre de 2017, los estadounidenses pasan doce horas al día conectados, destinando una media de $5 \mathrm{~h} 53 \mathrm{~min}$ a medios digitales, $3 \mathrm{~h} 58 \mathrm{~min}$ a ver televisión, $1 \mathrm{~h} 26 \mathrm{~min}$ a escuchar la radio, $24 \mathrm{~min}$ a los medios impresos y $21 \mathrm{~min}$ a otros.

Dentro del consumo de internet, las redes sociales condicionan mucho nuestros comportamientos, por ejemplo, de compra, en el $78 \%$ de los compradores online. Lo que más influye, en este sentido, es leer comentarios o valoraciones de otros consumidores más que recibir ofertas o ver publicidad directamente.

El componente relacional de las redes hace que hayan pasado a ser el gran ingrediente transversal a todos los sistemas en los que nos desarrollamos. De esta forma, lo sostenible adquiere nuevas dimensiones. Hablamos de entornos sostenibles gracias a relaciones sostenibles e hipereconectadas.

En el modelo ecológico, los medios tradicionales se contemplaban como exosistemas fuera de los contextos habituales en los que trascendía la vida cotidiana de cada sujeto. Hoy, internet en general, y las redes sociales en particular, habitan en cada uno de los escenarios en los que se desarrolla la actividad diaria. De hecho, no solo se integran en el seno de los microsistemas, sino que pasan a ser un contexto de pertenencia más, junto con la familia o los compañeros de trabajo, creando incluso nuevas identidades, diferentes a la real. Además, cobran especial relevancia en los mesosistemas, donde se llevan a cabo las relaciones entre los microsistemas, familia, trabajo o amigos, con un intercambio constante de mensajes multidireccionales. Y llegan a envolver y a condicionar todo el macroentorno social en el que se instaura la cultura, las creencias y los valores. En definitiva, cobran una especial relevancia en cada uno de los círculos en los que se desarrolla nuestra vida.

Según datos de la 19. ${ }^{\text {a }}$ Encuesta a usuarios de internet, «Navegantes en la Red», publicada por la Asociación para la Investigación de Medios de Comunicación (AIMC), un 76,4 \% de los encuestados asegura que le resultaría bastante difícil o muy difícil tener que vivir sin internet. De forma muy próxima, se sitúan el móvil, el correo electrónico o la mensajería instantánea, y a bastante distancia, los diarios y las revistas en papel. 
Las redes más utilizadas son Facebook, Twitter e Instagram. Y lo que más se sigue en redes son los medios de comunicación (lo que afianza el gran desarrollo de las audiencias sociales), que ven los programas al tiempo que los siguen por las redes comentándolos e intercambiando información y opiniones con otros televidentes. Las empresas o marcas también tienen una tendencia al alza en el seguimiento a través de redes sociales.

En cuanto a soportes de acceso, un 96,4 \% accede a internet a través del móvil. España se sitúa a la cabeza de los países de la Unión Europea en navegación por móvil, le siguen los Países Bajos, Croacia o Reino Unido. De este modo, la mayoría de los españoles se conectan a internet a través del móvil, seguido del ordenador portátil, ordenador de sobremesa y tableta.

La gran mayoría de los usuarios entre catorce y diecinueve años toma decisiones no planificadas sobre la marcha, relacionadas con el ocio, gracias a información que recibe continuamente en el móvil. ¿Pero qué efectos puede tener en los jóvenes el tiempo que pasan en las redes? Según un estudio realizado por la Universidad de Pittsburgh (Estados Unidos) y publicado en la revista científica American Journal of Preventive Medicine, cuanto más tiempo les dediquen los jóvenes, más probable es que se sienten aislados socialmente.

La investigación realizada a 1.787 usuarios estadounidenses de entre 19 y 32 años, analizó su presencia en las once redes sociales más populares en el momento, entre ellas: Facebook, YouTube, Twitter, Google Plus, Instagram, LinkedIn, Pinterest, Tumblr, Vine Snapchat o Reddit. A través de cuestionarios, se midió el aislamiento social percibido por cada persona. El resultado marcó claras diferencias entre los más y los menos conectados. Los sujetos que utilizaban las redes sociales durante más de dos horas al día tenían el doble de probabilidades de percibir aislamiento social que aquellos que les dedicaban menos de media hora. La frecuencia de uso es otro dato clave: los participantes que visitaban varias de estas plataformas digitales 58 o más veces a la semana presentaban casi el triple de probabilidades de tener un sentimiento de aislamiento social que quienes se conectaban nueve veces o menos. 
Los psicólogos afirman que el uso excesivo de redes sociales genera un empobrecimiento en las relaciones con la red básica de pertenencia que teje de otra forma que en el mundo virtual, la identidad social del sujeto. La razón es simple: cuantas más horas se invierten en estas plataformas, menos se dedican a otras experiencias más auténticas como son las relaciones personales presenciales. Los contactos en la red provocan una sensación de aislamiento. La búsqueda de contacto inmediato suele ser de poca calidad. Por otro lado, según los investigadores que llevaron a cabo a cabo el estudio, también es posible que los jóvenes recurran a las redes sociales porque se sienten socialmente aislados, por lo que «puede producirse una combinación de ambos factores».

Las propias características de algunas de las redes sociales analizadas pueden contribuir a la percepción de aislamiento. Por ejemplo, los usuarios pueden entrar en Facebook y ver cómo sus amigos comparten fotos de un divertido evento al que ellos ni siquiera fueron invitados, se puede despertar envidia en el otro. La forma de narrar idealizada lo que ocurre en nuestra vida en este tipo de redes no es como sucede en la realidad. La traslación a cómo se cuenta se filtra, adorna y, muchas veces, se exagera, lo que puede generar en otros el sentimiento de quedar fuera del sistema: ¿por qué este sí, y yo no?; ¿por qué tienen tantos «me gustas» y yo apenas consigo tener seguidores?. Este tipo de comparaciones pueden originar también distanciamiento en las relaciones con los más próximos en el mundo presencial.

Por otra parte, el hecho de que se dedique mucho tiempo a un medio, repercute en dejar de utilizarlo para estar con la familia o amigos, esto ya ocurría con la televisión. Simplemente, se trata de buscar soluciones para tratar de compartir más actividades de tiempo libre y de buscar una dieta equilibrada. Como todo en la vida, también en la alimentación digital, hay que saber buscar el equilibrio en el uso y en el tiempo destinado, para que sea beneficiosa. También se ha demostrado que un consumo controlado y equilibrado puede ser beneficioso para estimular la socialización de los jóvenes.

Siguiendo el planteamiento dual de Umberto Eco, han sido muchos los autores que han planteado todas las potencialidades que tienen las 
redes, otros -en cambio- se han detenido en todos los inconvenientes y peligros. Yo pienso que debemos ser críticos y equilibrados en nuestra percepción y, lejos de argumentos meramente apocalípticos o integrados, es necesario y preciso trazar a modo de informe DAFo las coordenadas de las oportunidades y amenazas que nos aporta la gran red y sus correspondientes redes.

La representación de lo que sucede en el entorno virtual es paralela a la que acontece en la vida presencial, posee una diversa paleta de escalas de colores. Así, cuando hablamos de fenómenos como el acoso, el terrorismo o los delitos o de realidades como la ciudadanía, cultura, voluntariado... pasamos a poner el prefijo «ciber» cuando compete al escenario digital. Solo de esta forma, diferenciamos si los delitos son en la red o en la calle, o la solidaridad se ejerce dentro o fuera de la pantalla.

Internet ha trastocado todos los elementos del proceso comunicativo y los ha succionado en parte. De esta forma, se ha convertido en un emisor tremendamente gigante de información. De hecho, se utiliza la prosopopeya «lo dice en internet», «está publicado en Facebook», «lo he visto en YouTube». Así, se personifican los soportes y se les da una entidad propia.

El tiempo que se destina a cada red semanalmente es bastante elevado. WhatApp es la red más utilizada para la mensajería online, siendo casi generalizado su uso semanal en casi un $90 \%$ de la población. El servicio de telefonía o videollamada se utiliza en menor medida, pero más que en otras redes. En cuanto al uso informativo de las redes, Facebook es la abanderada a la hora de consumir noticias, seguida de YouTube y Twitter.

Respecto al consumo por edades, el perfil mayoritario de Facebook y Gmail es de personas entre 35 y 54 años; mientras que Amazon prepondera entre los de edades comprendidas entre los 18 y 24; y es curioso como el buscador de Google y Google Maps prevalecen entre los mayores de 55 años. Snapchat es la red preferida por los adolescentes, seguida por Instagram.

Por lo que se refiere al consumo de medios, en función del nivel socioeconómico, también se observan diferencias destacadas, siendo 
internet, la radio, los diarios y las revistas más consumidos conforme más alta es la clase social, tendencia que se produce al contrario en el caso de la televisión.

En internet como canal, se han producido grandes transformaciones, la ubicuidad y la inmediatez, que antes eran características de medios como la radio, ahora se heredan en la red, que además de haber roto las barreras de espacio y tiempo, de ser síncrona y ubicua, también sirve como macrorepositorio de contenidos de los que poder hacer uso en cualquier momento. Así, la efimeridad de los mensajes se convierte en perpetuidad.

Pero donde, sin duda, se han observado más cambios, ha sido en los receptores, que han dejado de ser tales, para convertirse en prosumers o EMIREC. Esta hibridación de los roles que se ejercen de manera indistinta nos lleva a acrónimos que entremezclan ambas funciones. De esta forma, emitimos y recibimos, producimos y consumimos, constantemente. Por ello, el feedback ha pasado a ser la razón de ser de los social media. Sin embargo, no ha quedado ahí, en la retroalimentación de uno a otro, sino que se ha convertido en una fuente multidialógica, en la que los mensajes no solo son una respuesta, sino un gran caudal de uno a otros y de otros a unos.

Más que nunca, los mensajes encierran vínculos, sentidos de pertenencia o identidades digitales. Y hablando de mensajes, también en esta parte del proceso comunicativo, la red ha cambiado mucho los contenidos, intercalando diferentes sistemas expresivos, con secuencias narrativas paralelas, mediante enlaces, o rupturas temporales, de forma multimedia y transmedia. Todo un avance en los circuitos de navegación, en los que la lectura lineal ya forma parte del pasado.

Las potencialidades de internet son muy fáciles de advertir. Si hiciéramos una encuesta a pie de calle, ahora mismo, nos saldría un elenco importante de razones por las que los ciudadanos ya no podrían dejar de utilizarlo. Lo mismo nos ocurre a nosotros, los comunicadores y los investigadores, la forma de acceso a las fuentes informativas y documentales es tan fácil que hoy en día se hace mucho más rápido, contrastado y rico el ejercicio de nuestro trabajo. 
Para los educadores, no solo es una herramienta para encontrar todo tipo de recursos, sino también para interactuar con los alumnos y poder llevar a cabo prácticas con intermetodologías activas, que hacen mucho más innovadoras las formas de aprender. Además, los cursos gratuitos masivos en línea, posibilitan poder acceder al aprendizaje desde cualquier parte del planeta. Al mismo tiempo, el acceso a múltiples bibliotecas nos permite la conexión inmediata con las fuentes del saber y el conocimiento.

En el sector médico, la telemedicina permite diagnósticos directos e inmediatos a golpe de ratón, incluso la posibilidad de tener múltiples versiones ante unos mismos síntomas y contrastar los pronósticos que ofrecen diferentes especialistas.

En el sector de la cultura, internet abre el telón a un sinfín de películas, obras teatrales, espectáculos, galerías de arte, museos... y todo sin horarios establecidos y sin aguantar colas en la taquilla.

Los deportes también tienen su escenografía en la red, pudiendo ver en plano subjetivo las vueltas ciclistas, presenciar los goles desde el terreno de juego o subir al Everest sin ningún tipo de esfuerzo.

Para la economía, las opciones de realizar transferencias en directo, tanto a nivel micro como macro, sin duda acrecienta mucho las ventajas operativas y el caudal de recursos necesario. A gran escala, las cifras de ventas son multimillonarias y todo pasa por la red. A pequeña escala, las compras por internet nos permiten acceder a todos los escaparates del mundo, sin necesidad de movernos de nuestra casa.

El comercio electrónico es uno de los sectores que más se han desarrollado en la red. Son muchos los europeos que realizan sus compras ya a través de ella, necesitando poco tiempo en la decisión para la compra de algunos artículos que no requieren probarse o que son accesorios. Por el contrario, vestidos o zapatos, o muebles del hogar requieren más tiempo.

Y, así, podríamos hacer un repaso por todas las disciplinas y ámbitos temáticos y veríamos el modo en el que internet ha facilitado la búsqueda, el acceso y la interacción en este sistema ciberdemocrático, que igual que supone una ágora en sentido de ser copartícipes de toda la información y 
el conocimiento, nos permite llegar a compartirlo a través de las inteligencias múltiples que llamaba Gadner, la Sociedad Red de Castells también puede ser cuestionada.

Las amenazas vienen dadas por varios frentes, entre ellos, el temido control, cuyas fuentes son muchas. No somos libres ante los contenidos que narramos y que recibimos. El feedback, la autoría colectiva o las posibilidades de crear en la red como prosumer pueden entenderse como una ensoñación.

Nos preguntamos: ¿somos libres en la Red, tenemos el testigo de nuestras actuaciones?, ¿o seguimos siendo entendidos como «masa» al estilo de Ortega y Gasset?

El vídeo Prometeus, la revolución de los medios recrea una predicción de lo que será la red en el año 2050. El vídeo producido por la consultora Casaleggio Associati de Milán, relata la situación actual de la comunicación en internet y el futuro de la nueva comunicación, trata de los prosumers (productores y consumidores de información), de las transformaciones que sufrirán las grandes empresas y la política de adquisiciones y la importancia de la realidad virtual en la creación de entornos «virtualmente reales»».

No sabemos si lo que pronostica Prometeus será una realidad, pero, desde el inicio de siglo, el despliegue de redes ha ido creciendo de manera exponencial. Cada vez la inclusión de nuevas aplicaciones requiere menos tiempo. Las cifras hablan por sí mismas. El teléfono tradicional requirió 75 años para alcanzar 100 millones de usuarios, el teléfono móvil solo 16 años, WhatsApp e Instagram 2 años y Candy Crush, se ha expandido en poco más de un año.

Por otro lado, tenemos que plantearnos: ¿qué pasa con la huella que dejamos en cada una de nuestras acciones en la red? Nuestras acciones están sujetas a muchas miradas que pueden pasarnos factura de todo tipo. Saber cuál es nuestra intención de voto, controlar nuestras transacciones, nuestra huella digital... son formas de control. Así, el ágora digital convierte todas sus potencialidades en amenazas, el acceso a la información sin límites se ve restringido por la contaminación informativa, la información falsa y manipulada, el fraude informativo... 
Y todo ello en un universo en el que las brechas existen de forma clara, no todos los ciudadanos pueden acceder a la información porque siguen existiendo países ricos y pobres, no todas las personas están en lugares donde hay acceso a internet. Podemos hablar de brecha digital, económica, territorial, etaria y también de competencias.

En el mapa mundial de acceso a internet, podemos observar cómo mientras que en EE. uU., Australia o España, más de un $80 \%$ de la población son usuarios de esta, en Níger apenas se llega al 2,1\%, siendo la media mundial de un 48,2\%.

No todas las personas están preparadas al mismo nivel para saber utilizar esta herramienta. Como demuestran algunas investigaciones, el grado de competencia mediática es muy reducido entre la ciudadanía española. Entendemos el concepto de competencia en todas sus dimensiones, no solo en el uso instrumental de la tecnología, también conocer el lenguaje, la estética, la interacción o la ideología y valores. A este respecto, en un proyecto dirigido por Joan Ferrés i Prats, en el que participamos investigadores de todas las comunidades autónomas, comprobamos que apenas un 4,6\% pueden considerarse aptos en esta materia y llegaba a un destacado 95,4 \% el de ciudadanos suspensos. En el informe se concluye que: «El reforzamiento del sistema democrático no puede entenderse sin una ciudadanía crítica y consciente, que debe ser capaz de detectar valores y la carga ideológica de determinados mensajes».

Teniendo en cuenta lo que los navegantes serían capaces de hacer los ciudadanos por un like en redes sociales nos preguntamos: ¿dónde quedan los valores y principios? Ya Abraham Moles subrayaba la polución de noticias en los tiempos de medios controlados y controladores. De esta forma, frente a la contaminación informativa y la gran avalancha de mensajes que saturan el ecosistema comunicativo, es necesaria la educación mediática para llegar a una verdadera cultura de la participación, que como cualquier dieta que se precie, debe ser nutritiva, sana y equilibrada. Hay que cambiar la concepción de la red como instrumento meramente tecnológico, por una dimensión pedagógica y comunicativa. 
Saber manejar la herramienta no hace que seamos digitales. La expresión de «nativos» acuñada en 2001 por Marc Prensky para definir a las generaciones nacidas a partir de 1991, quienes han integrado en sus vidas las herramientas telemáticas de modo natural, sin tan siquiera plantearse en profundidad para qué sirven, ha sido revisada. No existe una apropiación real de la red porque el hecho de que los «nativos digitales» hayan nacido sabiendo «manejar» las tecnologías más modernas, no significa que estén alfabetizados digitalmente y sepan utilizar los contenidos con sentido crítico ni controlen con criterio y de manera eficaz todas las posibilidades comunicativas de los nuevos entornos. La diferencia entre esta concepción y la de los «inmigrantes digitales» resulta un estereotipo. Es más adecuado hablar en términos de «sabios» digitales e «iniciados».

Para llegar al auténtico constructo digital hay que estar «multialfabetizado», en el sentido que otorga el New London Group a mediados de los noventa, en todas las dimensiones:

- Dimensión instrumental: enseñar a manejar el hardware y el software.

- Dimensión cognitiva: habilidades de uso inteligente de la información (búsqueda, selección, intercambio y difusión de información) a través de las nuevas tecnologías.

- Dimensión actitudinal: fomentar actitudes racionales ante la tecnología (ni tecnofobia, ni tecnofilia) y actitudes sociales positivas en la comunicación, como el respeto o la empatía.

- Dimensión axiológica: tomar conciencia de que las TIC no son neutrales, desarrollar valores éticos, para evitar conductas socialmente negativas.

La combinación de todas estas dimensiones de manera holística conducen a la construcción y desarrollo del ciudadano digital alfabetizado en un entorno TRIC (tecnologías de la relación, la información y la comunicación), a lo que hemos llamado humanismo digital. El concepto de TRIC, bautizado en el año 2012, en el seno del laboratorio TRICLab, en GICID, junto con mi compañero de investigación José Antonio Gabelas, 
supera el mero determinismo tecnológico, el término «relación» imbrica todo el potencial de la multialfabetización que se produce en las interacciones en el plano creativo de cada uno de los coautores. En relación, somos más y mejores. En relación, un entorno mejor es posible.

TRICLab, forma parte del Grupo de Investigación y Comunicación e Información Digital (GICID) de la Universidad de Zaragoza. Lo componemos un equipo de docentes, comunicadores e investigadores de la educación y de la comunicación que abogamos por la superación del instrumentalismo tecnológico, poniendo en el centro del proceso el «factor $\mathrm{R} »$. La «R» simboliza las conexiones en un contexto de empoderamiento mediático por parte de docentes y estudiantes activos, un sistema de relaciones unidas por el compromiso y la responsabilidad de todos/as con todos/as. Tiene sentido hablar de humanismo digital si nos concienciamos, primero sobre un uso humano de la tecnología, es decir, usarla para tender puentes entre personas, para comunicarnos y colaborar.

La educomunicación ha permitido crear puentes para aprovechar el potencial del factor relacional de la comunicación en la educación y las posibillidades y recursos educativos en el ámbito de la comunicación.

Como señala Kaplún, «solo participando, involucrándose, investigando, haciéndose preguntas y buscando respuestas, problematizando y problematizándose se llega al conocimiento. Se aprende de verdad lo que se vive, lo que se recrea, lo que se reinventa y no lo que simplemente se lee y se escucha». Así, podemos ver en esa pirámide invertida cómo lo que aprendemos mejor es lo que descubrimos.

Desde la educación para los medios, se alberga un proceso en el cual el sujeto pasa por diferentes niveles: «alfabetizado, consciente, activo, crítico y social» hasta convertirse, de manera integral, en un «sujeto creativo» o «perceptor participante», en el sentido de que, por un lado, el proceso de percepción lleva al individuo a captar, interpretar y reelaborar todo tipo de información, independientemente del código o sistema expresivo utilizado y de la modalidad de soporte en la que se encuentre, a través de sus diferentes sentidos. Y, por otro, es participante, atendiendo a la confluencia de los términos «partícipe»y «actante», es decir, 
persona que participa, en este caso, en los contenidos de la red, y que es un actor activo o protagonista de los mismos. Es decir, en esta expresión, confluyen también las dos esferas de creación y recepción de mensajes, ahondando en la dimensión de que el ciudadano debe operar y sentirse en el entorno virtual tanto partícipe como emisor.

Los parámetros educomunicativos abarcan y redimensionan la educación y la comunicación, pero nuestra propuesta es integrar también la salud. De modo que educación, salud y comunicación constituyan un espacio común y sinérgico que posibilite, promocione y también contenga las competencias digitales.

En la Primera Conferencia Internacional para la Promoción de la Salud que se celebró en Ottawa, Canadá, en 1986 se recoge que «la promoción de la salud es el proceso de capacitar a las personas para que aumenten el control sobre su salud, y para que la mejoren. No es simplemente responsabilidad del sector sanitario, va más allá de los estilos de vida saludables para llegar al bienestar».

Esta premisa es tenida muy en cuenta, desde la Dirección General de Salud Pública del Gobierno de Aragón, y aplicada en los programas Pantallas Sanas, y Cine y Salud, que vienen desarrollándose desde hace más de una década.

En 1993, la oms plantea un nuevo enfoque de la educación para la salud, debido al documento Habilidades para la vida $(\mathrm{HpV})$, que entendemos como «grupo de competencias psicosociales y destrezas interpersonales que forman el entorno de manera que sea propicio para la salud».

El modelo de comunicación, salud y educación, abre tres dimensiones:

La primera supera las posiciones proteccionistas, al dar más importancia a las potencialidades que a los riesgos.

La segunda dimensión presenta modelo basado en el desarrollo comunitario.

La última dimensión se relaciona con el componente social, de forma holística, exige estar integrado en una red de colaboración con el propio entorno educativo, los diferentes agentes socioculturales, los propios medios de comunicación y la sociedad en general, para hacer real el desarrollo comunitario. 
La oms propone un grupo de diez habilidades que ayudan a las personas a comportarse de manera saludable de acuerdo con la motivación individual, el contexto social y cultural en que se vive.

Se trata de que aprendan a ser, a convivir, a hacer y a aprender, como recoge el Informe Delors de 1996. Teniendo en cuenta el empoderamiento (apropiar, potenciar, fortalecer), en la dimensión comunitaria. No solo abarca a los pacientes/estudiantes, toda la comunidad educativa queda integrada. Las «habilidades para la vida» $(\mathrm{HpV})$ funcionan cuando las políticas, los entornos saludables, los agentes sociales, sanitarios, culturales y educativos, mediáticos, están articulados.

Estos principios sostienen un modelo de comunicación, salud y educación abiertamente constructivo, que abre tres dimensiones. La primera viene dada por el hecho de que se trata de un modelo positivo, puesto que en él prevalece la promoción de la salud y la educación, superando posiciones proteccionistas al privilegiar las posibilidades y potencialidades sobre los riesgos. La segunda dimensión presenta un modelo basado en el desarrollo comunitario. Los estudios indican que los niños, adolescentes y jóvenes ejercitan sus prácticas culturales, que son lúdicas y sociales, en el ámbito del ocio digital, un ámbito que afecta a los propios usuarios, pero también a sus iguales y a sus padres y madres básicamente.

El desarrollo comunitario conduce a la última dimensión, que viene definida por el hecho de que se trata de un modelo holístico. Este componente social exige estar integrado en una red de trabajo y colaboración con el propio centro escolar o entorno educativo que ocupe, los diferentes agentes socioculturales que intervienen en la acción educativa, los propios medios de comunicación y la sociedad en general para hacer visible y real el desarrollo comunitario.

Por consiguiente, las habilidades para la vida serán aquellas aptitudes necesarias que permitan un comportamiento asertivo, adecuado y positivo, prospectivo y capacitante; que faciliten abordar el conflicto del crecimiento integral, así como los retos y desafíos de la vida diaria; que una misma habilidad, como el pensamiento crítico y creativo, pueda facilitar diferentes situaciones psicosociales positivas, como la capacidad para resolver conflictos o la asertividad en la presión del grupo de iguales 
y entrar en conexión con diferentes competencias digitales como la reutilización de contenidos y producciones, lenguajes, experiencias, formatos, medios o soportes o la gestión de la identidad digital, muy relacionada con subjetividades o inteligencias múltiples.

Las diferentes habilidades para la vida las podemos agrupar, de manera relacional e integradora, en tres vasos comunicantes:

- Cognitivas

- Autoconocimiento

- Pensamiento creativo

- Pensamiento crítico

- Toma de decisiones

- Emocionales

- Empatía

- Manejo de emociones y sentimientos

- Manejo de tensiones y estrés

- Sociales

- Comunicación asertiva

- Relaciones interpersonales

- Solución de problemas y conflictos

Lo personal (autocuidado), lo relacional (adaptación social) y el entorno (riesgos ambientales), se consolidan como dimensiones de este desarrollo de bienestar.

Las competencias digitales son hoy una garantía del empoderamiento en el ciberespacio y, en concreto, en las redes sociales. El ciudadano se convierte en participante proactivo y crítico no solo cuando ejercita estas competencias, sino también cuando las destrezas psicosociales o habilidades para la vida forman parte de su interacción con el entorno digital en su dimensión cognitiva, emocional y social.

La competencia digital debe unir todas las dimensiones para llegar a tener un tratamiento integral mediante el cual el sujeto sea capaz de ser un «perceptor participante» en sentido completo, no solo determinado por el manejo tecnológico o la capacidad de acceder y leer los mensajes. 
Conocer su trasfondo, los valores que se esconden detrás de los mensajes y quienes son las fuentes de información y los dueños de las mismas son, sin duda, registros importantes para ser un ciudadano digital crítico ante el uso de los nuevos medios, aplicaciones y redes.

El factor relacional es el eje que conecta los usos, consumos e interacciones de los participantes en la Sociedad Red y de la competencia digital de los EMIRECS dependerá que funcionen de una forma responsable, ética y solidaria.

El aprendizaje «para la vida» debe de nutrirse de todas las dimensiones instrumental, cognitiva, actitudinal, axiológica y emprendedora para llegar a ser un proceso retroalimentario, en el que el análisis, la reflexión, la acción y la creación procomún sean competencias extensibles a los múltiples escenarios y entornos, presenciales y virtuales, en los que cada día convivimos. 


\section{COMUNICACIONES PRESENTADAS}




\title{
INNOVACIÓN EN LA DIFUSIÓN DEL ARTE EN CONTEXTOS DIGITALES: LA GESTIÓN DE LA COMUNICACIÓN DEL MUSEO SOROLLA EN INTERNET Y REDES SOCIALES
}

\author{
Francisco Cabezuelo Lorenzo \\ Universidad Complutense de Madrid \\ Raquel Caerols Mateo \\ Universidad Francisco de Vitoria \\ Mónica Viñarás Abad \\ Universidad San Pablo CEU
}

\section{Resumen}

Las redes sociales suponen una oportunidad para la gestión de la comunicación en los museos. Este trabajo analiza las iniciativas más innovadoras para la difusión del arte en los contextos contemporáneos digitales. Para ello, toma como estudio del caso el Museo Sorolla de Madrid, que fue casa y taller del genial pintor valenciano de fama universal. Este trabajo reúne la confluencia de distintas disciplinas y enfoques: las humanidades, el arte, la comunicación corporativa, el entorno digital, la publicidad y las relaciones públicas. Se añade la particularidad de que este tipo de pequeños museos no suelen ser objeto de estudio, a pesar de la gran relevancia que tienen en el panorama museístico, donde el protagonismo lo ocupan otros grandes centros como el Museo del Prado (Madrid) o la Ciudad de las Artes y las Ciencias (Valencia). Metodológicamente, esta propuesta realizará un análisis de contenido de la página web y de los perfiles en redes sociales de este museo para conocer la gestión del contenido y de la participación en la red social. Entre los resultados y conclusiones, los resultados indican la necesidad de una estrategia más definida que aproveche el potencial íntegro que tienen las redes sociales, ya que el contenido no se utiliza como estrategia y la participación no responde a la esperada durante 
estos hitos tan relevantes. Por otro lado, cabe afirmar que el Museo Sorolla contribuye a la creación de la marca Ciudad de Madrid como destino cultural, pero no solo desde un ámbito local, sino desde una perspectiva más amplia, generando marca España, y completando también la identidad de la Comunidad Valenciana por el origen del autor que da nombre al museo y que siempre tuvo su región como fuente de inspiración.

Palabras clave: comunicación digital; Museo Sorolla; redes sociales; arte; interactividad.

\section{INTRODUCCIÓN, JUSTIFICACIÓN Y CONTEXTO}

$\mathrm{E}$

L MUNDO DE LA COMUNICACIÓN SOCIAL, tanto en el ámbito global como local, ha sufrido una revolución gracias a la digitalización de las interacciones sociales. En este ámbito, tanto internet como las redes sociales son los nuevos protagonistas en los flujos comunicativos tanto en el ámbito publicitario como periodístico. Lo mismo ocurre con el mundo de la comunicación estratégica o corporativa, con la comunicación integral, en definitiva.

Esta realidad ha afectado al mundo de los museos. Los profesionales del mundo del arte y sus centros, con los museos al frente, no han sido menos conscientes que otras organizaciones, empresas e instituciones en la importancia de las redes sociales. Los museos viven un nuevo escenario donde son muchos los expertos que consideran que la comunicación debe ser una parte estratégica de la gestión (Cordón 2012, Camarero y Garrido 2010, Jung 2010, Mateos 2012, Olivera \& Capriotti 2010). Hoy hay más visitantes virtuales que reales (Del Río 2012).

Sin embargo, esta concepción de la comunicación digital como un eje vertical es relativamente reciente. En realidad, allá por el año 2006, las redes sociales apenas tenían presencia y la web era más un nuevo soporte de información que de participación. No es hasta el año 2010 cuando se aprecia el comienzo de esta explosión (Gómez-Vílchez 2012) y se «observa cierta improvisación en las actuaciones de los museos en 
red y la falta de programas de comunicación web estructurados que den un sentido y unos objetivos concretos a los distintos medios a utilizar». Por su parte, Losada y Capriotti $(2015,901)$ llegan a la misma conclusión: «los principales museos de arte a nivel mundial y español disponen de una amplia y muy buena presencia en internet, aunque su actividad y predisposición al diálogo no es tan destacable y puede ser mejorada».

En general, una vez incorporadas las redes sociales en la planificación de la comunicación, se demanda un enfoque estratégico en función de los objetivos específicos de la comunicación digital. Si estos estudios cuantitativos reflejan un alto uso de las redes sociales, pero una estrategia poco definida, el análisis de casos concretos recoge iniciativas muy interesantes, la mayoría en la red social Twitter. Así, en 2010 se puso en marcha la iniciativa \#AskACurator, se generaron más de 26.000 tuits donde miles de expertos de todo el mundo respondieron a las preguntas de los usuarios. Por otro lado, desde 2014 se celebra a través de esta red social de microblogging la denominada \#Museumweek, una iniciativa de Twitter para dar a conocer a los museos de esta red y en la que participan instituciones de toda la Unión Europea.

Los social media son una oportunidad para un sector cuya comunicación suele estar muy condicionada por el tipo de gestión y los recursos, es necesario un enfoque estratégico que permita alcanzar los objetivos (Fortaleza 2012). El valor de este estudio radica en la novedad y originalidad de la campaña analizada. En el caso del Museo Sorolla. Se trata de un museo de pequeño tamaño con colecciones muy específicas en edificios representativos.

Frente a los grandes museos españoles como El Prado (Madrid), Guggenheim (Bilbao) o la Ciudad de las Artes y las Ciencias (Valencia), el Museo Sorolla es un pequeño museo monotemático centrado en la figura y obra de un único artista. Su misión es la de promover al máximo el conocimiento y disfrute del legado del pintor valenciano Joaquín Sorolla y Bastida -Valencia, 27 de febrero de 1863 - Cercedilla (Madrid), 10 de agosto de 1923- por todo tipo de públicos, en el convencimiento de que este legado, y en particular las obras de Sorolla, puede ofrecerles una experiencia emocional y estética positiva y enriquecedora, estimular 
sus sentidos, avivar en ellos la conciencia del sentido de la vista como instrumento de conocimiento y animarlos a utilizar sus propias capacidades creativas, según la propia web del museo.

Del mismo modo, de acuerdo con esta misma fuente, la misión del museo está definida en el testamento de su fundadora, Clotilde García del Castillo, en estos términos: «La conservación y exposición al público de las obras auténticas ejecutadas por D. Joaquín Sorolla y cuantos cuadros, objetos artísticos, muebles, etc., existan en la casa 37 del Paseo del General Martínez Campos y de cuantas obras se adquieran en el futuro con destino a dicho museo». De este modo, sobre esta base, el museo se plantea como objetivos conservar el legado de Sorolla, documentar y catalogar sus colecciones como medio para su conservación y conocimiento, e investigar y promover la investigación sobre la obra de Joaquín Sorolla y su contexto desde todos los puntos de vista. Del mismo modo, entre sus funciones están las de exponer las colecciones en las mejores condiciones para su contemplación y su interpretación, difundir el legado de Sorolla a todos los niveles y hacerlo accesible al mayor número posible de público. Finalmente, también tiene como misión el intentar incrementar las colecciones de pintura para completar la representación de todas las fases de su producción.

Joaquín Sorolla fue uno de los pintores españoles más internacionales de su momento. De orígenes humildes, huérfano y criado por sus tíos, desde niño demostró muy pronto su arte en la Escuela Normal Superior de la Provincia de Valencia. Por las tardes, al salir de la escuela, iba a las clases de dibujo del escultor Cayetano Capuz en la Escuela de Artesanos. Posteriormente, ingresó en la prestigiosa Escuela de Bellas Artes de San Carlos en 1879. En paralelo, aprendió cerrajería con su tío, José Piqueras Guillén. También trabajó como ayudante en el estudio del distinguido fotógrafo Antonio García Pérez. De este modo, conocería a su hija, Clotilde García del Castillo, con la que Sorolla se casó en septiembre de 1888. En 1884, triunfó en la Exposición Nacional de Madrid, alcanzando una beca para estudiar en la Academia Española de Bellas Artes en Roma. En 1885, Sorolla partió para Roma y luego a París. Al terminar sus años en Roma, y después de pintar en Asís, regresó 
a Valencia en 1889 , y al año siguiente trasladó su casa y estudio a Madrid.

Sorolla alcanzó la fama mundial con paisajes mediterráneos y escenas marinas de inspiración valenciana y mediterránea. Así, animado por el éxito conseguido con sus resplandecientes imágenes del Mediterráneo y estimulado por su amor a la luz y a la vida de sus soleadas playas se dedicó a pintar dichas escenas, más alegres y agradables, que le proporcionarían fama mundial, tal y como recogen Muller y Burke (2004). En Londres, en una de esas experiencias internacionales conoció al magnate estadounidense Archer Milton Huntington, creador de la Hispanic Society of America en Nueva York. Gracias a Huntington, Sorolla expuso en Nueva York en 1909 con un éxito rotundo y aquel le hizo su encargo más importante en la vida del artista: la colección Visión de España. En 1921, mientras Sorolla pintaba en el jardín de su casa, sufrió su primer ataque de hemiplejia. Incapacitado desde entonces, murió el 10 de agosto de 1923 sin ver expuesta su gran obra, la colección Visión de España, que no sería instalada definitivamente hasta 1926 en Nueva York.

\section{OBJETIVOS Y METODOLOGÍA}

El Museo Sorolla ocupa la casa que fue la vivienda del pintor y su familia desde 1911. Las colecciones se distribuyen por todas las zonas visitables de esta. El domicilio mantiene de manera casi intacta la decoración que tuvo en su día cuando estaba habitada por el pintor. De este modo, la colección de pintura convive con el mobiliario y los objetos originales de la vivienda familiar de los Sorolla. De este modo, se puede decir que se trata de una de las casas y talleres de artista de fama internacional del siglo xx mejor conservadas de Europa. De hecho, forma parte de la red Artist's Studio Museum Network (http://www.artiststudiomuseum.org/).

Para ver la relación entre arte y redes sociales, en el caso de este trabajo, la muestra elegida en esta ocasión se centra en el Museo Sorolla, no solo por su valor como casa-museo, sino también por su ingente y completa actividad digital. Es una institución pequeña pero muy activa 
y muy querida tanto por los públicos locales como por los internacionales. Es un museo de mucho éxito en Madrid, pero que sin embargo se sitúa fuera de la órbita más masificada de los grandes museos de la capital de España, alejado del triángulo formado por El Prado-Thyssen-Reina Sofía.

Por otro lado, este trabajo se justifica en la medida que desde hace años el Museo Sorolla junto con otros cuatro museos (el Museo Lázaro Galdiano, el Museo del Romanticismo, el Museo Cerralbo y el Museo Nacional de Artes Decorativas) decidió trabajar de forma conjunta para posicionarse y cómo aprovechan los hitos más importantes en su sector para generar notoriedad y participación en Twitter. El actual texto tiene como base o punto de partida el estudio titulado «Redes sociales y museos: análisis de la campaña en Twitter para el Día Internacional de los Museos y Noche de los Museos», publicado en la Revista Latina de Comunicación Social en 2017 (220-234).

En esta ocasión, se trata de un caso de estudio concreto centrado solo en las peculiaridades del Museo Sorolla y la campaña promovida por el centro con motivo de la celebración de la llamada Noche de los Museos, pero ahora contextualizado dentro del marco de acciones digitales desplegadas por esta prestigiosa institución museística dentro de sus acciones de comunicación. Desde 2013, los responsables del Museo Sorolla han apostado por iniciativas que parten de una identidad común y que les posiciona y distingue en el panorama museístico (Viñarás 2014). En 2015, la campaña \#5Museos supuso una novedosa iniciativa en la que, durante cinco días, cada museo animaba a visitar al resto a través de las redes sociales con el eslogan «5 Museos, otro Madrid» (Viñarás Abad y Caerols Mateo 2016).

El objetivo principal es analizar la comunicación en la red social Twitter del Museo Sorolla en este periodo tan relevante, y como objetivos secundarios saber si se genera contenido específico para este acontecimiento aprovechando su relevancia, y conocer y evaluar el nivel de compromiso y participación o engagement que se alcanza durante este periodo con los usuarios. Los resultados nos permitirán conocer en profundidad esta iniciativa desde dos perspectivas, la de la institución y la del público: cómo gestionan los museos su comunicación en redes 
sociales en el hito más importante del año, y por otra parte, el grado de participación e interés del público. Esto último es de vital importancia, cuando distintos estudios han demostrado la variedad de intereses de los visitantes virtuales (Kravchyna y Hastings 2002) en una sociedad sobreinformada. «El usuario en redes sociales se siente parte del proyecto museístico, se identifica con sus valores, se compromete con la misión de la institución y además recomienda el museo a sus conocidos» (Merín 2015).

Para la realización de este trabajo se ha puesto en marcha una monitorización o análisis de contenido para la recogida sistemática de la información publicada por el Museo Sorolla en su perfil de Twitter. El análisis se ha dividido en dos apartados: el contenido que permite evaluar la gestión del museo y el engagement, que permite evaluar la participación y por lo tanto el comportamiento en forma de respuesta del usuario. Se trata de un análisis cuantitativo que permite valorar la eficacia de la iniciativa (Carreres 2015). Este análisis de contenido, recoge lo que se conoce en redes sociales como monitorización. Se trata de establecer una escucha activa sobre la opinión de los seguidores y seleccionar unos indicadores clave de desempeño, también conocidos en el ámbito anglosajón como KPI (key performance indicator) que permiten realizar una medición, extrayendo posteriormente resultados y conclusiones sobre las acciones efectuadas. Los KPI son fundamentales para alcanzar los objetivos en el plan de medios sociales (Mejía Llano 2013) y conocer así la eficacia de la planificación.

Las unidades de muestreo en este caso son los mensajes publicados por la cuenta de Twitter del Museo Sorolla y las unidades de registro los tuits, retuits y respuestas. Para la codificación del material se establece un sistema de categorías a partir de las variables. El periodo de campo fue del 11 al 25 de mayo de 2015, ya que se celebran los dos hitos más importantes en la vida museística internacional: la Noche de los Museos y el Día Internacional de los Museos, celebrados el 16 y 18 de mayo respectivamente. El trabajo se completa además en esta ocasión con la revisión de otras herramientas digitales del museo como sus perfiles en Facebook, Instagram e incluso TripAdvisor. 
En primer lugar, en cuanto los mensajes emitidos por el Museo Sorolla y su análisis de contenido, permitirá conocer su tipología y relacionarla con la eficacia en las redes sociales. El contenido es hoy una forma de estrategia, que se conoce como marketing de contenidos (Font y Cuesta 2012; López 2012). El hecho de cuantificar y tipificar los mensajes publicados (tuit, retuit o respuesta) permitirá concluir si el museo opta por una comunicación más unidireccional, de tipo informativo, o apuesta por la bidireccionalidad, siendo más participativo y abierto al diálogo. El análisis del formato del contenido (enlace, texto, foto, audio o vídeo) resulta interesante para valorar el atractivo de la cuenta para los usuarios. Otra variable de interés es el uso de los enlaces, muy conveniente para enriquecer el texto permitiendo ampliar la información (Lucio 2011). Por último, en relación a los mensajes escritos por los museos (tuiteos y respuestas), se analiza el uso de hashtags y su tipología: propios del museo (exposiciones, eventos, etc.), de la Noche de los Museos y el Día Internacional de los Museos o ajenos. Esta herramienta es fundamental en la difusión del contenido en Twitter y su uso es determinante.

En segundo lugar se ha analizado el engagement, es decir, la capacidad de las empresas e instituciones de generar un vínculo o compromiso con la audiencia a través de sus acciones en la red. Para Jiménez es «la fórmula de construcción de relaciones sólidas, de lazos a través de los nuevos medios» (2013). De manera general, la fórmula toma el nombre de engagement rate (ER) y aunque existen diversas fórmulas, para este trabajo se utiliza la propuesta por Mejía Llano $(2013,267)$, que aglutina los elementos más comunes en estas fórmulas. El numerador: representa las interacciones en el perfil de Twitter (número de menciones + número de retuits) en un periodo determinado, dividido entre el número de tuits totales del periodo. El denominador representa el número de seguidores de la cuenta de Twitter.

\section{ANÁLISIS Y RESULTADOS}

Sin duda alguna la principal herramienta digital con la que cuenta el museo es su propia página web (figura 1). Se trata de una web alojada 
dentro de la del Ministerio de Cultura y Deporte del Gobierno de España accesible a través del enlace https://www.mecd.gob.es. La web del museo tiene un total de siete grandes apartados en los que se muestran las diferentes secciones temáticas divididas en $a$ ) Visita, b) Qué ver, c) Colecciones, d) Actividades, e) El Museo,f) La Fundación y g) Investigación. En la sección sobre visitas se muestran los datos relativos al contacto, dirección, horarios y acceso (bus, metro y bicicleta). También se ofrece información sobre el precio de las entradas (tarifa), cómo obtener las entradas online, las normas de visita, la posibilidad de reservas para grupos, gestión de visitas privadas, cuestiones ligadas a la accesibilidad para personas con movilidad reducida y un enlace a la tienda del museo.

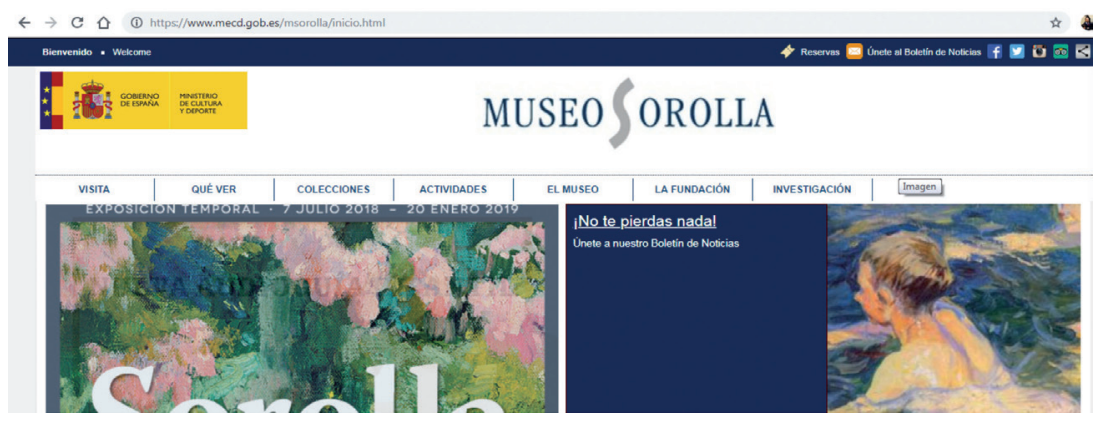

Figura 1. Página web del Museo Sorolla

Fuente: www.mecd.gob.es

En la sección «Qué ver» de la web del museo hay un enlace a los contenidos de la exposición permanente y otro al de la las exposiciones temporales, como la de «Sorolla y la moda» y «Sorolla en París», que son algunas de las más recientes y exitosas de 2017 y 2018. Del mismo modo informa sobre las pinturas del Museo Sorolla cedidas a otros museos temporalmente o exposiciones sobre Sorolla fuera del citado museo madrileño. En esta colaboración con otros centros también facilita en su web un enlace a la ya citada «Ruta 5 Museos». Del mismo, desde esta sección de «Qué Ver» se accede a la «Sala de prensa». 
En la sección «Colecciones» de la web del museo hay un acceso al catálogo y a los diferentes criterios para el ingreso de las colecciones, las reproducciones de fondos y el préstamo de las obras. No hay que olvidar que los museos están vivos y activos y no dejan de generar exposiciones dentro y fuera de sus paredes. Además, en el caso del Museo Sorolla no se trata solo de una pinacoteca. El museo consta de colecciones de cerámica, escultura, fotografía antigua, dibujos y grabados, joyería y orfebrería y sobre todo pintura (óleos y acuarelas).

Por otro lado, es muy importante la sección titulada «Actividades», donde se especifican, más allá de las visitas, los eventos y actividades para públicos específicos. Hay varios colectivos especiales como las familias, los adultos y los niños. Así, una iniciativa muy particular es la generación de una denominada Mi Pequeña Historia del Arte. Se trata de una actividad extraescolar en la que los niños a través de los objetos que el propio Joaquín Sorolla reunió en su casa-taller pueden conocer cómo es la gestión de un proceso creativo pictórico y descubrir el arte desde sus orígenes hasta el siglo xx. En cada sesión, los menores exploran un periodo de la historia del arte e incluso reproducen una obra intentando seguir el estilo, las técnicas y tendencias del momento histórico estudiado.

Del mismo modo, en esta sección está el apartado llamado «Wikimedia». Se trata de una iniciativa digital para dotar de contenidos digitales la prestigiosa web de contenidos compartidos Wikipedia. La misión de esta actividad es la de ampliar y mejorar los contenidos sobre Joaquín Sorolla en internet,. Para ello, el Museo Sorolla en colaboración con Wikimedia ha organizado un total de cuatro talleres para que los asistentes descubran y aprendan las herramientas y procedimientos de trabajo en Wikipedia para editar contenidos relacionados con la figura de Joaquín Sorolla, su familia y el museo. Los talleres de 2018 fueron dirigidos por Rubén Ojeda. En ellos, cada participante podría traer su propio portátil y conectarse al wifi del museo para generar los contenidos.

En el apartado correspondiente a la sección titulada «El Museo», se recoge la misión y visión del mismo, su historia, organización y sus planes de futuro, entre los que destaca la ampliación de sus instalaciones al edificio paralelo de la calle Zurbano. Del mismo modo, en esta sección 
se muestra un listado de la carta de servicios del museo, de sus patrocinadores y de los canales para obtener una beca, prácticas o realizar un voluntariado en el Museo Sorolla.

Entre las secciones principales de la web está otro enlace o hipervínculo a la Fundación Sorolla, origen del museo. Ahí se puede ver su historia, estatutos, organización, actividades, club de amigos, y su memoria anual junto con su plan de actuaciones. Finalmente, la última sección titulada «Investigación» va destinada a todos aquellos estudiosos de la obra y vida de Joaquín Sorolla. El museo investiga principalmente sobre sus colecciones, sobre la vida del genio valenciano, sobre el propio edificio del museo, sobre la historia del Museo y sobre su público. El museo tiene publicados los catálogos de la pintura, la escultura y la cerámica. A través de esta web se puede acceder a los catálogos online de pintura de Sorolla; escultura; mobiliario; cerámica; vidrio; el catálogo de dibujos y 6.593 fondos del archivo de fotografía antigua. El museo tiene la obligación de atender a los investigadores que solicitan el acceso a la biblioteca, el archivo o los almacenes de colecciones, para lo que pone en su web a disposición de los investigadores un formulario de contacto. El museo tiene la política que considera que el acceso a los fondos del museo debe realizarse sin menoscabo del normal funcionamiento de los servicios de visita pública, respetando las adecuadas condiciones de conservación de los bienes culturales. De este modo, estas tareas de investigación están sujetas unas normas. Cada vez facilitar más contenidos digitales a los investigadores. Así, el Museo Sorolla facilita la consulta de su colección a través del catálogo en línea www.cer.es. Igualmente, los fondos de la biblioteca del museo se encuentran disponibles en el Catálogo BIMUs de la Red de Bibliotecas de Museos.

Respecto al uso de redes sociales, destaca el uso de Facebook (figura 2), Twitter e Instagram. En el caso de Facebook, el Museo Sorolla tiene una muy buena valoración en esta red. Obtiene un 4,7 puntos de 5 posibles, de acuerdo con la opinión de 1.846 usuarios. Este perfil de Facebook cuenta con 52.363 seguidores y con 51.846 likes. Del mismo modo, casi todas sus secciones están alimentadas por contenidos diversos: fotos, vídeos, publicaciones, comentarios y, especialmente, la tienda, ya que desde Facebook se pueden comprar piezas de la tienda de la casa-pinacoteca del pintor valenciano. 


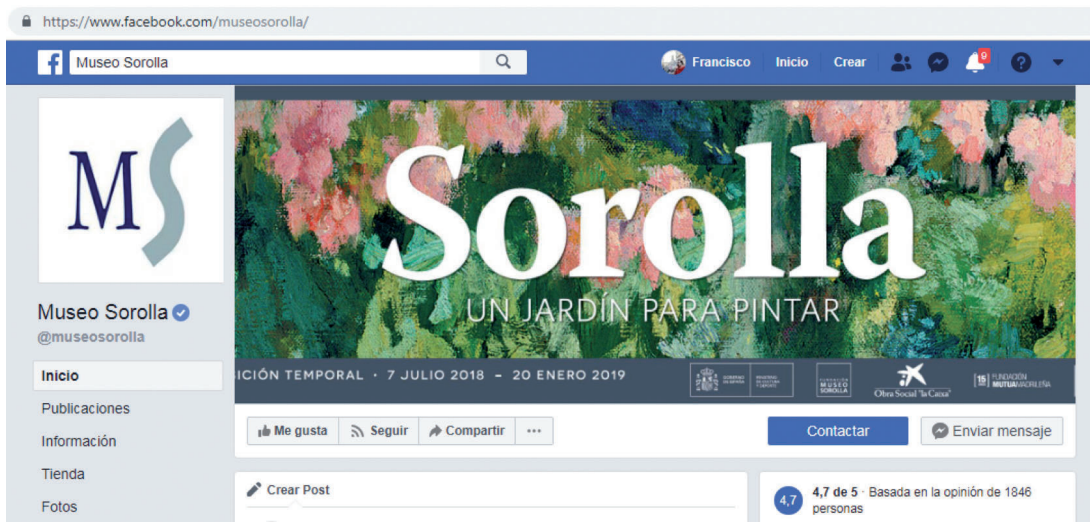

Figura 2. Perfil de Facebook

Fuente: www.facebook.com/museosorolla

Pero sin duda alguna, entre las redes más visuales y aptas para un museo se encuentra Instagram (https://www.instagram.com/museo sorolla) (figura 3). Para un museo de pintura, es de especial relevancia. La imagen es la protagonista en esta red, por lo que las fotografías, carteles, imágenes e iconos de todo tipo protagonizan cada post en esta red social. El Museo Sorolla cuenta con 730 publicaciones en Instagram, 53.500 seguidores y sigue a otros 47 perfiles de la misma red.

- https://www.instagram.com/museo_sorolla/

(0) | Instagram

a Busca

Entrar Registrarte

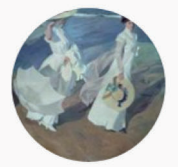

museo_sorolla * seguir

729 publicaciones $\quad 53,5 \mathrm{k}$ seguidores $\quad 47$ seguidos

Museo Sorolla

La Casa Museo de Sorolla en Madrid.

www.museosorolla.es

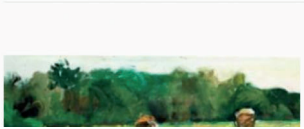

团 PUBLICACIONES (9) ETIQUETADAS

Figura 3. Perfil de Instagram del Museo Sorolla

Fuente: http://www.instagram.com/museo_sorolla 
Paradójicamente, en la actual sociedad de la información, el ocio y el entretenimiento propio de la cultura occidental, los museos compiten con restaurantes, teatros, hoteles, cines y otras opciones de las diferentes industrias culturales. Por ese motivo, la web del Museo Sorolla tiene también un enlace a TripAdvisor (figura 4). Esta web de origen estadounidense que proporciona reseñas de contenido relacionado con viajes e incluye foros de viajeros fue fundada en febrero de 2000 por Stephen Kaufer y Langley Steinert. Su idea original no era crear un sitio generado por los usuarios para intercambiar opiniones, más bien era para expertos y profesionales, pero pronto los contenidos de los usuarios se convirtieron en los protagonistas. Muy pronto el número de comentarios de los consumidores superó ampliamente al número de comentarios profesionales, ahí fue cuando el sitio realmente se convirtió en la actual compilación de opiniones y comentarios de viajeros. En el caso de esta web, los servicios son gratuitos y son los usuarios quienes proporcionan la mayor parte del contenido. El sitio web se financia con publicidad. En este espacio de opiniones, el Museo Sorolla cuenta con un total de 5.701 opiniones y se sitúa en el puesto número 20 de la clasificación de los sitios más valorados en Madrid por los turistas. Obtiene una puntuación de 4,5 puntos sobre un total posible de 5 . E1 $74 \%$ de los usuarios lo valora como excelente, el $22 \%$ como muy bueno, el $2 \%$ como normal, y tan solo el $1 \%$ como malo y otro $1 \%$ como pésimo.

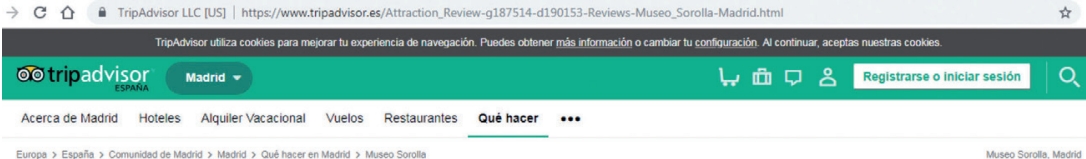

\section{Museo Sorolla}

OOOOO 5.701 opiniones IN. 20 de 878 cosas que hacer en Madrid Inseos, Museos de arte

- Cl General Martínez Campos, 37, 28010 Madrid, España | (1) Hoy abre: Cerraco

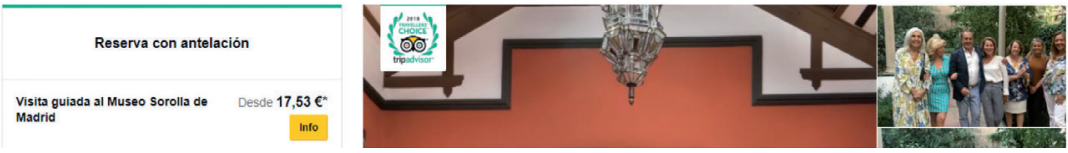

Figura 4. Perfil del Museo Sorolla en TripAdvisor

Fuente: TripAdvisor España

ÍNDEX 
Pero en estos momentos, la red social por antonomasia es Twitter. La cuenta de Twitter del Museo Sorolla está activa desde marzo de 2011 y a fecha de 1 de octubre de 2018 ha publicado en estos años más de 1.140 imágenes y vídeos, casi todos ellos reproducciones de lienzos y acuarelas del pintor valenciano. A fecha de verano de 2018 cuenta con más de 49.500 seguidores, al tiempo que esta cuenta oficial sigue a un total de 320 cuentas de Twitter. ¿Qué iniciativas más de valor ha puesto en marcha este museo a través de Twitter? Para dar respuesta y ver su posición respecto a otros de sus características, recurrimos al estudio de caso analizado por Viñarás Abad, Caerols Mateo y Gonzálvez Vallés (2017), durante el Día Internacional de los Museos de 2015. Entonces, el Museo Sorolla emitió un total de 12 tuits, 14 retuits y 4 respuestas. En comparación con los otros cuatro museos de Madrid con los que se alió ese año, se observa una gran diferencia entre ellos a pesar de ser una iniciativa conjunta. El día que más actividad se registró fue el 18 de mayo coincidiendo con el Día Internacional de los Museos, con un $18 \%$ de los tuits contabilizados a nivel global. Fue el día de mayor actividad en Twitter para los cinco museos. No así el día 16 de mayo, la Noche de los Museos, donde apenas hubo actividad. En cuanto al contenido de las publicaciones, en general, prima el texto frente a la imagen: el 45,4\% contiene solo texto, el 31,4 \% lo acompaña de un enlace, el 22,3 \% añade una foto y solo un $0,9 \%$ lo completa con un vídeo o un audio. Sin embargo, en el año 2018, con motivo del Día Internacional de los Museos, el Museo Sorolla solo publicó un tuit temático relativo a esta cuestión (figura 5).

La última categoría del análisis de contenido es el uso del principal recurso y esencia de Twitter, el hashtag. Se ha analizado el uso del hashtag solo en tuits y respuestas, ya que estas son las publicaciones que redacta el museo. El primer dato a señalar es que el 52,5\% de todos los tuits y respuestas analizados tienen hashtag, concretamente, $74 \%$ de los tuits enviados lo contenían, mientras que solo estaba presente en el 43,3\% de las respuestas. En segundo lugar se han clasificado los hashtag; del total analizados, el 9,3\% corresponde a actividades propias, el relacionado con el Día Internacional del Museo, representa el 34 \% y el 9,7 \% hace referencia a la Noche de los Museos. El resto constituyen un $47 \%$. 


\section{Museo Sorolla@MuseoSorolla·18 may.}

M Feliz \#DiaInternacionalDeLosMuseos con entradas gratuitas y visitas al @MuseoSorolla para todos a las 17:00, 17:30 y 18:30

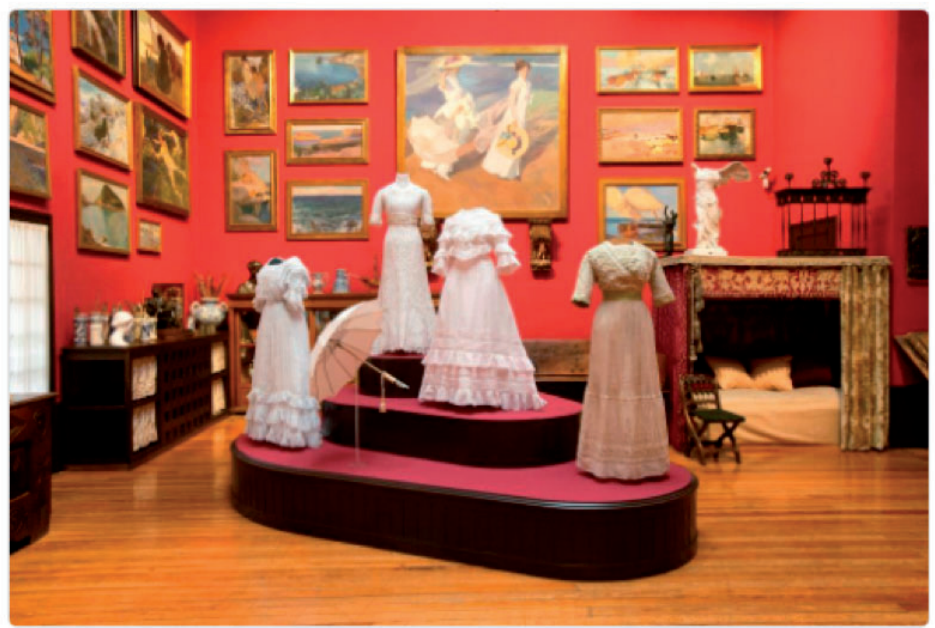
1
七】 51
210

Figura 5. Tuit del Museo Sorolla con motivo del Día Internacional de los Museos el 18 de mayo de 2018

Fuente: Twitter/Museo Sorolla

El grado de compromiso o implicación de los seguidores de las cuentas de Twitter de los museos, depende del nivel de interacción generado por diferentes acciones: favoritos, retuits y menciones. Además del número de seguidores, el engagement busca medir la participación de estos con los contenidos del museo. Esta participación, que puede tomar diferentes formas, supone que esta persona interactúa con el museo, con su marca representada y expresada en la red social. Por el contrario, el Museo Sorolla, tiene frente a sus competidores/aliados un número de retuits y favoritos considerablemente alto para la actividad que ha registrado en Twitter: tan solo 16 tuits y respuestas en el periodo analizado. Esta interacción solo tiene explicación por el número tan elevado de seguidores que ostenta, 22.000, y por la gran proyección 
nacional e internacional que tienen Joaquín Sorolla y su obra. Evidentemente, con un uso más apropiado, es uno de los museos que incrementaría su visibilidad de manera espectacular, ya que su público parece estar deseoso de recibir cualquier información de este museo para compartirla. A partir de la fórmula aplicada de engagement rate, los resultados muestran un ratio bajo para todos los museos. Esto se debe posiblemente a varios motivos: una actividad escasa en la red, contenidos que en algunos casos no generan interés y no logran interacción; actividades que no se comunican, en general, un uso meramente informativo de la plataforma y no social.

\section{CONCLUSIONES}

Con más de veinte siglos de historia, los museos han vivido en poco más de veinte años dos revoluciones transcendentales, la nueva museología a nivel particular e internet a nivel global, a lo que se suma el aumento de la oferta museística tanto pública como privada. Tras este análisis se extraen una serie de conclusiones en torno a la gestión estratégica de la comunicación de los museos en el discurso digital y por lo tanto, en su entorno social. Se parte de las más generales y de carácter estratégico para llegar a las más específicas y tácticas.

Este trabajo constata la necesidad de mejora en el diseño y ejecución de campañas digitales. No se percibe una estrategia que sistematice el contenido y la participación en Twitter. Los museos generan contenido específico pero de forma insuficiente y desigual. No parece que exista un plan de social media que promueva las actuaciones en la plataforma. Hay un claro desaprovechamiento de las herramientas que esta red pone a su alcance, principalmente el hashtag, y la visibilidad de sus acciones es prácticamente nula, a pesar de los eventos tan representativos y mediáticos que se producían en el periodo monitorizado. Como se ve, los museos - como es el caso del Museo Sorolla- siguen confiando todo el peso de su presencia digital a la página web tradicional. 
El Museo Sorolla es un ejemplo de un pequeño museo madrileño que sabe rentabilizar los hitos que generan visibilidad, pero en general, todavía es mucho lo que queda por hacer. En el caso de 2018, el Museo Sorolla ha mantenido poca o casi nula actividad en Twitter durante los hitos de la Noche de los Museos y el Día Internacional de los Museos. En estas fechas tan significativas de la vida museística, es cuando deberían reforzar su comunicación, sobre todo en redes sociales, para conseguir notoriedad. De la misma manera, en las redes sociales no se fomenta ni el diálogo, ni la interactividad, ni los auténticos contenidos sociales. Prima el contenido propio frente al contenido compartido cuando en redes sociales se valoran las menciones y alusiones a otros usuarios. De este modo, se puede afirmar que hay un predominio de la información frente a la participación. Los museos utilizan Twitter para informar y mostrar al público lo que hacen, en una comunicación prácticamente unidireccional y muy poco social. No hay una actitud de escucha activa hacia sus públicos, ni se motiva la participación lo suficiente. Esto se traduce en un bajo nivel de engagement y poco aprovechamiento del poder comunicativo de la imagen, excepto en el caso de Instagram. La fotografía no se emplea de manera regular, y los audios y vídeos son muy pocos teniendo en cuenta el peso de estos elementos en la actual cultura audiovisual, multimedia y digital. Sin embargo, entre los puntos fuertes, el Museo Sorolla sabe aprovechar muy bien los acontecimientos históricos y las efemérides. Esta idea es una buena excusa para desarrollar un gran potencial en la divulgación del patrimonio contenido en sus salas y como promoción de sus exposiciones y eventos.

En general, se puede decir que los museos han incorporado las redes sociales en su gestión, el diseño de estrategias de comunicación online y su ejecución es compleja y requiere de competencias específicas. La comunicación online supone un cambio de paradigma que nos obliga a pensar y a actuar de forma diferente, en muchos casos alejada e impensable en el desarrollo tradicional de la comunicación. El Museo Sorolla, a pesar de sus limitaciones, es buen ejemplo de museo de éxito en las redes sociales. 


\section{BIBLIOGRAFÍA}

Camarero, C. y M. J. Garrido. 2011. «Incentives, Organisational Identification and Relationship Quality among Members of Fine Art Museums». Journal of Service Management, 22.

Carreres, M. 2015. El uso de Twitter en cinco museos especializados [Trabajo fin de grado]. Universidad ceu San Pablo.

Cordón, D. 2012. Museums Communication: What Do They Really Offer? The power of preserving intangibles. http://cort.as/-E6D4

—. 2013. Museos y Gabinetes de Comunicación: sinergias eficaces para el futuro. http://cort.as/-E6D6

De la Peña, J. 2014. «¿Sirven para algo las redes sociales en el sector cultural?». http://cort.as/-E6D7

Del Río, N. 2013. «Recursos educativos en museos online de arte contemporáneo. Tipología e implantación». Arte, Individuo y Sociedad, 25 (2): 233-246. DOI: http://cort.as/-E6DC

Fernández, L. A. 2010. Museología: Introducción a la teoría y práctica del museo. Madrid: Fundamentos Istmo.

Fortaleza Oliver, M. 2012. «El papel de los museos en las redes sociales». Biblios 48. Valencia: Biblios. DOI: 10.5195/biblios.2012.66

Gómez Vílchez, S. 2012. «Museos españoles y redes sociales. Evaluación de preferencia y participación». Telos, 90.

Ibáñez Echeverría, A. 2010. Museos, redes sociales y tecnología 2.0. http://cort.as/-E6DE

Jung, Y. 2010. «The Ignorant Museum: Transforming the Elitist Museum into an Inclusive Learning Place». En: The New Museum Community: Audiences, Challenges, Benefits. Edinburgh: MuseumsETC.

Kravchyna, V. y S. Hastings. 2002. "Informational Value of Museum Web Sites». First Monday, 7 (2). http://cort.as/-E6DF

López Font, L. y U. Cuesta. 2012. «Comunicación corporativa y redes sociales: cambiarlo todo para que nada cambie». adComunica: revista de estrategias, tendencias e innovación en comunicación, 3: 23-25. Castellón: Asociación para el Desarrollo de la Comunicación 
adComunica, Universidad Complutense de Madrid y Universitat Jaume I. http://cort.as/-E6DH

Losada Díaz, C. y P. Capriotti. 2015. «La comunicación de los museos de arte en Facebook. Comparación entre las principales instituciones internacionales y españolas». Palabra Clave, 18, 3: 889-904. DOI: 10.5294/pacla.2015.18.3.11

Lucio, A. 2011. El valor de los enlaces en un texto. http://cort.as/-E6DM Mateos, S. 2012. Manual de Comunicación para museos y atractivos patrimoniales. Gijón: TREA.

Merín, C. 2015. Museos y redes sociales, de la difusión a la interacción. http://cort.as/-E6DR

Muller, P. E. y M. B. Burke. 2004. Sorolla: The Hispanic Society. Nueva York: The Hispanic Society of America.

Rodríguez, S. Revista ICOM España CE Digital, 5. http:/cort.as/-E6DV

Mejía Llano, J. C. 2013. La guía del Community Manager. Estrategia, táctica y herramientas. Madrid: Anaya Multimedia.

Oliveira, A. y P. Capriotti. 2013. «Gestión estratégica de los públicos en museos. De la identificación a la comunicación». El Profesional de la Información, mayo-junio, 22, 3: 210-214.

Túñez, M. 2012. «Los periódicos en las redes sociales: audiencias, contenido, interactividad y estrategias comerciales». Estudios sobre el mensaje periodístico, 18, 1: 221-239.

Viñarás Abad, M. 2011. La gestión de la comunicación de los museos de Madrid: auditoría de relaciones públicas. Madrid: Cersa.

—. 2014. «Identidad corporativa y museos: los casos del Museo de Artes Decorativas, Museo Cerralbo, Museo Lázaro Galdiano, Museo del Romanticismo y Museo Sorolla». En: Nuevas Culturas y Sus Nuevas Lecturas, 701-714. Madrid: McGraw Hill.

— y R. Caerols Mateo. 2016. «\#5Museos: un caso de éxito sobre la oportunidad de las redes sociales para generar engagement». En: Congreso Internacional de Relaciones Públicas. Valencia: Universidad CEU Cardenal Herrera. 


\title{
LA OFERTA DE PÓDCAST DE LOS MEDIOS LOCALES COMO OPORTUNIDAD PARA GANAR AUDIENCIA JOVEN Y ESTRATEGIA DE NUEVOS INGRESOS
}

\author{
Andrea Delgado Hernández \\ Universidad de Navarra
}

\section{Resumen}

A lo largo de la última década la irrupción de internet, los avances tecnológicos, y los cambios sociales y económicos han llevado a los medios de comunicación a la realidad en la que nos encontramos: una audiencia heterogénea, consumidora de diferentes formatos; una irrupción masiva de medios nativos digitales, y una masificación de las redes sociales con su consiguiente alteración a la hora de consumir información.

En este panorama, los medios de comunicación sienten la necesidad de ajustarse a los nuevos tiempos y es aquí donde surge la oportunidad. En la obligación de adaptarse a internet y las nuevas formas de consumo, muchos ven la ocasión de acceder a una audiencia diferente y nuevas fuentes de financiación.

Diarios digitales que proponen nuevos formatos, radios locales que amplían su contenido con el consumo asincrónico y los pódcast son ejemplos que analizaremos para presentar la siguiente hipótesis.

Los formatos online suponen una nueva estrategia para ganar audiencia y, como tal, pueden convertirse en una nueva vía de ingreso, siendo la oferta de pódcast un ejemplo de ello.

En este artículo analizaremos cinco casos. Los pódcast en la plataforma online del Diario de Navarra, DN Plus; los pódcast locales de las tres cadenas comerciales COPE Navarra, Onda Cero Navarra y SER Navarra, y el pódcast Luces en el horizonte como pódcast nativo digital.

En la metodología se analizarán los pódcast de las plataformas citadas anteriormente durante la semana del 25 al 29 de junio de 2018, teniendo en cuenta como variables descriptivas, entre otras: el contenido, el formato o género 
narrativo empleado, la frecuencia y tipo de difusión, el tipo de acceso mediante pago o no, y su estrategia general multiplataforma para ganar audiencia.

Palabras clave: radio local; pódcast; nuevos medios; medios online; multiplataforma.

\section{INTRODUCCIÓN}

$\mathrm{L}$

A LLEGADA DE INTERNET TRAJO CONSIGO una multitud de posibilidades para el mundo de la radio. La red rompió la primera de las barreras -la limitación de la cobertura geográfica-, generalizó la globalización de la radio y la transformó en un medio de comunicación universal, sin barreras.

Internet abría un nuevo mundo de posibilidades, mayor cobertura, una audiencia potencial no limitada por la geografía, nuevos lenguajes $\mathrm{y}$ formatos, mayor facilidad de interactividad y la opción del consumo asincrónico.

La aparición del podcasting generó la posibilidad de consumir «radio», contenido sonoro, de manera asincrónica, y que las emisoras tradicionales pudieran ofrecer su contenido más allá de la continuidad del directo.

Hoy, tras un proceso de evolución y de adaptación a internet de más de veinte años hablamos de multiplataformas, convergencia periodística y estrategias longitudinales de los medios de comunicación. En ese contexto, las emisoras tradicionales han desarrollado sus webs para reforzar la oferta radiofónica. Carmen Peñafiel (2007) señala que son «complemento a sus transmisiones hertzianas, como un servicio de valor añadido hacia sus oyentes o como medio para contactar con su audiencia y, así, obtener información o facilitar su participación, pero sin valorar las propiedades de la red como medio de comunicación válido para difundir contenidos periodísticos». 
En este trabajo, veremos como las webs de los medios tradicionales usan su plataforma online como complemento a su lenguaje de origen, sea la prensa escrita o la radio. Estos medios han basado gran parte de su contenido en la reproducción del contenido de la matriz tradicional, pero también empiezan a crear contenido propio y exclusivo para el formato online.

No hay que olvidar además, que uno de los mayores valores de las multiplataformas se encuentra en el feedback e interactividad con el oyente y en la forma en que consume el medio. El medio de comunicación online cuenta con un mayor grado de comunicación con el oyente que las cartas, los mensajes en directo o las llamadas telefónicas. Ahora el oyente puede dejar sus comentarios y sugerencias a través de múltiples formas.

En cuanto a las rutinas de consumo del medio, la radio se definía en sus inicios como un medio de comunicación fugaz, lo dicho se perdía al momento de decirlo. Ahora esa información está disponible más allá del directo, puede ser consumida al gusto y tiempo del oyente, ahora la radio perdura en su consumo en diferido.

\section{OBJETIVOS}

El objetivo de la investigación es describir la adaptación de las emisoras y de los medios tradicionales locales, al panorama digital a través de las plataformas online, en concreto, a través de su oferta de pódcast.

Se estudiará cómo las emisoras rentabilizan el contenido sonoro de antena a través de las plataformas online y, asimismo, se comprobará cómo un medio impreso desarrolla material sonoro para establecer una nueva forma de comunicación, captar audiencia y ampliar la estrategia de negocio.

Se comparará el estudio de tres medios tradicionales y su oferta local con un contenido sonoro nativo digital, con el fin de establecer las diferencias de estrategia de difusión con el material sonoro en continuidad de las emisiones en directo. 


\section{METODOLOGÍA}

En la muestra para el análisis hemos elegido a las tres grandes cadenas nacionales: COPE, Onda Cero y SER, la plataforma digital del Diario de Navarra, DN Plus y el pódcast nativo Luces en el horizonte.

En el análisis de contenido de las plataformas elegidas identificaremos las siguientes variables descriptivas: contenido, formato, frecuencia, tipo de difusión, tipo de acceso al contenido, pago o gratuito, y la estrategia general de la multiplataforma.

En el caso de las emisoras nacionales observaremos su plataforma digital según los parámetros destacados anteriormente sin profundizar en la estructura total de esta, nos centraremos en su estrategia general de cara a la audiencia y la presentación estética y organizativa, sobre todo del material sonoro. Para el examen concreto del desarrollo y explotación del audio también observaremos el desarrollo de las emisoras locales en Navarra, como ejemplo que se puede extrapolar a las demás emisoras de la plataforma. La investigación se realizó en el periodo de dos semanas del 15 al 30 de junio de 2018.

En el caso de Diario de Navarra observaremos el contenido sonoro de su plataforma online de pago $\mathrm{DN}^{+}$.

Y con el estudio del pódcast nativo Luces en el horizonte complementaremos el análisis anterior de los contenidos sonoros de medios tradicionales, con fin de identificar sus características en las diferentes variables de estudio.

\section{RESULTADOS}

\subsection{COPE}

La cadena radiofónica tiene presencia en internet desde 1997, pero fue entre el 2006 y 2008 cuando la organización apostó de forma sólida 
por la presencia en el mundo online. En 2008 su portal web fue reconocido como el mejor portal web de radio en 2008 en el marco de la V Edición de Los Mejores de prnoticias.

La nueva web fue definida por COPE como «un portal multimedia desarrollado como web 2.0 basado en la información, la opinión y la participación de los usuarios»».

Cope.es incorporó entonces la novedad de completar sus contenidos con los sonidos de audio de la propia emisora y la posibilidad de sintonizar la emisión en directo de cada una de las emisoras que poseían en toda España. A las opciones de escuchar la radio en FM o AM se incorporó la escucha online.

Cope.es organiza su contenido entorno a la relevancia de temas y programas. En un scroll horizontal hacia abajo vemos como se alternan los programas más oídos y destacados de la emisora con las noticias ordenadas por temáticas. Primer lugar para Herrera en COPE, seguido de Deporte, España, el programa La linterna...

Además hay que destacar que lo primero que vemos en la página es la posibilidad de emisión en directo y los dos pódcast más destacados del día anterior. Cuando se clica, la emisión en directo lleva a otra página adicional del streaming en directo y desde ese mismo punto se sintonizar la emisora local que se prefiere escuchar. También en la cabecera de la página se destaca la posibilidad de oír el último boletín del día.

En cuanto al contenido sonoro lo vemos presentado en dos tipos de formato: audio o pódcast. En todos los casos el acceso es gratuito.

Dentro de las noticias diferenciamos las que tienen contenido multimedia con un símbolo de audio o vídeo en la foto de la noticia.

Los audios corresponden a extractos de la emisión en directo que completan las noticias escritas de forma sonora. Dentro de las noticias con sonido se expone el audio, que corresponde a extractos de la emisión en directo, y un resumen escrito de la información, aunque en ocasiones se transcribe el audio.

Bajo el formato pódcast, por su parte, se engloban los audios de los programas o secciones completas, editoriales, monólogos, etc. creados 
a partir de secciones y programas del directo, y también los pódcasts de contenido propio y exclusivo para la web.

Tienen un apartado concreto en la web que clasifica los pódcast $100 \%$ online en dos temáticas: actualidad y entretenimiento, con trece categorías (Cope y acción, Distrito COPE, Oído cocina, El albero, Mente plena, Radio Carlitos Delux, Hablar en familia, Tiempos modernos, Artesanos de la fe, Música ligera, Geniales de COPE, Sin mi identidad y Hollywood Land); y deporte, con once series de pódcast (Futsal COPE, This is fútbol, Tercer tiempo, Área chica, De rosca, Cope GP, Copedaleando, Esto es fútbol, Showtime, Planeta Eurosport y Fit run COPE.

Cada uno de ellos tiene una duración diferente que va desde los diez minutos hasta las dos horas. La frecuencia también depende del pódcast, y varía entre frecuencia semanal, quincenal o mensual. Se presentan con un anuncio sonoro inicial y una careta de entrada informativa del pódcast en cuestión.

En cuanto a la difusión del material sonoro, se hace a través de las noticias de la web y redes sociales, tanto en las generales de la emisora como en las propias de los programas. Y los mismos canales utilizan para la difusión de los pódcast de programas o secciones provenientes de la emisión en directo.

En cuanto a los pódcast de contenido propio para la web, cada uno de ellos dispone de su propio Twitter como canal de difusión y varios de ellos, no todos, también se difundea través de la plataforma Ivoox. Todos los pódcast permiten descargarlos de forma gratuita pero no disponen de un sistema de suscripción.

La estrategia de cope.es busca aumentar el contenido de interés a partir de la web con noticias de actualidad reforzadas con los audios de antena y proponer un tipo de contenido propio para la web que permite llegar a otro tipo de público. Una audiencia con un gusto temático más especializado centrado en materias específicas.

Sobre la estrategia de negocio, los contenidos online permiten aumentar la retroalimentación de la comunicación entre emisor y receptor, acceder a los contenidos cuando se desee y conseguir mayor difusión a 
partir de las redes sociales y canales de suscripción. Esto permite a la emisora poder comercializar otro tipo de contenidos ya sea en forma de noticias, secciones o programas patrocinados con una cuña, vídeo o banner al comienzo del contenido sonoro o publicidad dentro de los propios audios o pódcast.

\subsubsection{Cope.es Navarra}

En la web de COPE Navarra la estrategia multimedia es la misma que la emisora general. Volcado de noticias en la web en las que incluyen el audio, en el caso de que el tema se haya tratado en directo en antena; y volcado de las secciones y programas en formato pódcast. La frecuencia de publicación online es diaria, el orden de los pódcast es cronológico y el acceso gratuito.

La difusión de las noticias y pódcast se realiza mediante los redes sociales. El Facebook de cope Navarra es poco activo, no cuelgan todas las noticias ni pódcast, con una media de publicación de una o dos por semana. En Twitter son más activos, con varias publicaciones todos los días, difunden más el material sonoro de la web además de crear contenido propio en directo con vídeos de las entrevistas del día.

En general la estrategia local de la multiplataforma está menos desarrollada que la multiplataforma nacional, la web se trabaja como una especie de hemeroteca de almacenaje de sonidos, sin desarrollar realmente los contenidos sonoros con la finalidad de ganar audiencia o rentabilizar económicamente los recursos.

En redes sociales sí que vemos cierto camino hacia la explotación de ese contenido sonoro como un contenido diferente, sobre todo en Twitter donde, con vídeos en directo, sí que intentan apelar a otro tipo de audiencia más joven y sobretodo consumidora de contenido deportivo. El contenido que más se explota en las redes sociales de cope Navarra es el deporte. 


\subsection{Onda Cero}

Onda Cero fue la primera cadena radiofónica en emitir su señal por internet. Fue pionera al comenzar sus emisiones en la red en mayo de 1996.

En sus inicios, con la creación de la multiplataforma online, su apuesta se basaba en la posibilidad de escuchar en directo y el contenido creado $100 \%$ online para la web con reportajes, entrevistas o especiales.

En 2010 Onda Cero integró a su plataforma las redes sociales apostando por la comunicación y participación con los oyentes. Y en 2018 vuelven a reestructurar la multiplataforma orientada sobre todo a potenciar los contenidos de los programas, se crea a cada uno de ellos página propia, y a desarrollar los contenidos creados propiamente para el mundo online.

La multiplataforma online nacional se desarrolla como un portal de noticias. La página de inicio está ordenada por temáticas y a continuación programas. Hay dos tipos de noticias: las acompañadas de audios provenientes de antena, y las que no contienen material sonoro, redactadas para la web.

Centrándonos en el material sonoro volvemos a tener dos tipos: audios y pódcast.

El audio es contenido sonoro proveniente de antena que se utiliza para reforzar las noticias online.

En relación a los pódcast, además de los provenientes de los programas y secciones de antena, Onda Cero potencia el contenido sonoro $100 \%$ propio para la web con ocho pódcast online: tres de temática deportiva (4 cuartos, Ellas juegan en la onda y Onda fútbol), uno de cine (Ficciones sonoras), uno sobre cultura (La cultureta), uno de temática medioambiental (Latitud cero), uno sobre música (Rock and Roll animal) y un pódcast de temática regionalista centrado en el caso catalán (Noticiero catalán).

Permite una mención especial el pódcast Ficciones sonoras, que en la web se presenta con página propia en la que no solo se disfruta del programasino que cada capítulo es completado con material visual y escrito: fotos, vídeos y reseñas. 
Todos los pódcast se difunden a través de suscripción gratuita y redes sociales. La cultureta y Ellas juegan en la onda disponen de Twitter propio, los demás se difunden en las redes sociales generales de la cadena.

Ondacero.es desarrolla una estrategia online orientada a conseguir un nuevo público consumidor de contenidos en la red aunque no sea el target de la emisora. Además estos contenidos permiten la suscripción, lo que también abre vías de financiación alternativas, no solo el consumo de pago sino fórmulas como el patrocinio o partners dentro de los pódcast.

\subsubsection{Ondacero.es Navarra}

El portal web local desarrolla una página de inicio donde los pódcast se presentan en orden cronológico con frecuencia diaria. Todo el contenido online corresponde a un programa, sección o entrevista de antena. No se desarrolla la web como portal de noticias donde se pueda estar permanentemente informado, y tampoco se elaboran contenidos sonoros $100 \%$ online.

Se da una importancia destacada a la escucha en directo, el acceso a los pódcast, a los programas y secciones. Pero la imagen visual de la multiplataforma local de la emisora se corresponde más con una página de almacenamiento de audios.

La difusión de los contenidos sonoros se realiza mediante la suscripción y redes sociales. Las dos redes sociales utilizadas para la difusión son Facebook y Twitter. En Facebook se comparten algunos de los programas y secciones, sin frecuencia establecida, no son especialmente activos en esta plataforma. En cuanto a Twitter, se desarrolla un poco más el discurso con los oyentes a partir de la publicación más frecuente de secciones y noticias, alguna encuesta y concursos.

La apuesta local se orienta en la misma línea de la emisora nacional en relación a conseguir una audiencia suscrita a los contenidos y proveniente de las redes sociales más que de la antena tradicional. Difiere de esta línea estratégica nacional en la creación de contenido noticioso propio de actualidad. 
Se utiliza y explota muy poco el formato multiplataforma, la web se utiliza como hemeroteca y almacén de audios, más que como una vía para sumar audiencia o generar recursos alternativos.

\subsection{Cadena SER}

Esta parte de la investigación ha tenido que ser revisada y reescrita ya que el 12 de septiembre de 2018, tres meses después de la semana elegida de muestra, la Cadena SER lanzaba una web y plataforma completamente nueva, el último cambio anterior a esta fecha había sido en 2014.

La Cadena SER acaba de relanzar su portal multiplataforma. La nueva página de inicio sigue dando protagonismo, en primer lugar, a la escucha en directo. Como las demás cadenas, presenta en su portada un portal de noticias ordenadas por temáticas, actualidad, tecnología, deporte...

Cabe destacar la importancia dada a tres voces de la cadena con una sección destacada «Las voces de la radio» donde encontramos la opinión de Iñaki Gabilondo, Pepa Bueno y José María Izquierdo sobre temas de actualidad.

Haciendo scroll encontramos las secciones de: programas, vídeos, pódcast, la sección correspondiente a la emisora local de la zona geográfica que te encuentras, en nuestro caso «Noticias radio Pamplona», y una sección en la que se puede acceder a otros medios de comunicación del Grupo Prisa.

Acerca de la presentación del material sonoro, también disponemos de dos tipos de material: audios y pódcast.

Dentro del audio tenemos la emisión en directo y los audios que provienen de la emisión en antena, que se encuentran dentro de noticias para completar la información. Al igual que las webs de las dos cadenas anteriores no todas las noticias se completan con sonidos.

Hay que subrayar la presentación de los audios de las noticias. Nada más pinchar el audio, el material sonoro arranca con un anuncio visual y sonoro, lo curioso es que tras el anuncio visual, el vídeo reproduce de forma escrita el audio que se está escuchando, de manera que el audio se puede escuchar y leer al mismo tiempo. 
Al respecto del material de pódcast cadenaser.com ofrece una gran plataforma de retransmisión donde se pueden ordenar los programas por relevancia, alfabéticamente o por temporadas.

Hay que destacar que la página web de la Cadena Ser desarrolla una plataforma propia para la escucha de audios: PlaySER, que se carga en una página diferente de la web central, para reproducir el streaming en directo los contenidos sonoros online almacenados como pódcast o a la carta. Desde esta plataforma, además, se puede seleccionar la emisora local que se desea escuchar tanto en directo como a la carta.

El contenido de todos estos pódcast está creado a partir de los programas de antena y se puede disponer de ellos en escucha online, por descarga o suscripción.

La Cadena SER también propone contenido sonoro $100 \%$ online, con la peculiaridad de que no lo difunde ni presenta desde su página web sino desde la plataforma Podium Podcast, el canal red de podcast del Grupo Prisa. La SER presenta en portada y de forma alterna cinco pódcast, por ejemplo: El pódcast de Vice, que trata temas que preocupan e interesan a los jóvenes; Aquí hay dragones, sobre cine; Boyero on Fire, basado en las respuestas que Carlos Boyero da sobre cine, fútbol, cultura y sociedad a sus seguidores; De mujer a mujer, un pódcast de nueve episodios sobre nueve mujeres víctimas del conflicto en Colombia; y Olafo, cinco episodios sobre el accidente aéreo que tuvo lugar en Mejorada del Campo en 1983.

Referente a la difusión de este material sonoro, cadenaser.com cuelga todas sus noticias, con o sin audios, programas y secciones en sus redes sociales y propone la suscripción gratuita a su plataforma de pódcast.

En el caso de los pódcast alojados en Podium Podcast, a partir de la plataforma de la Cadena SER se accede a esta web y ahí se pueden escuchar, descargar los progremas y suscribirse a ellos.

La estrategia de la Cadena SER es convertirse no solo en una multiplataforma de emisora, sino en crear un mundo de convergencia entre los diferentes medios, soportes y plataformas del Grupo Prisa. No se 
trata de una táctica solamente de la cadena para ganar audiencia o conseguir diferente formas de negocio, que también lo es, pero la estrategia empresarial general se encamina a fortalecer la presencia global del Grupo Prisa también a través de los contenidos de Podium Podcast.

Esto se ejemplifica en cómo a partir de la web de la cadena se puede acceder a otros medios, o en cómo en las noticias se incorpora información de otros medios del grupo y en cómo en Podium se incluyen pódcast originales de emisoras de América Latina. En definitiva, se trata de crear una estrategia de negocio conjunta, de forma que se tiene acceso a un público potencial mucho mayor y a estrategias de financiación conjuntas.

\subsubsection{Cadenaser.com Pamplona}

Radio Pamplona presenta su plataforma como un portal de noticias de actualidad, donde genera noticias a partir del contenido de antena pero también de contenido propio escrito para la plataforma online.

Diferenciamos también dos tipos de material sonoro, el audio proveniente de antena incorporado a las noticias y el contenido sonoro de «A la carta».

Dentro de la sección «A la carta» podemos encontrar todo el contenido sonoro de la emisora, los audios de entrevistas o secciones y los pódcast de los programas enteros. Estos se presentan en orden cronológico de volcado, con frecuencia diaria.

La difusión de los contenidos se realiza a partir de redes sociales o suscripción y en este sentido sigue la misma estrategia que la plataforma nacional.

En cuanto a la estrategia de negocio de la plataforma local, pretende ofrecer una mayor oferta a sus seguidores con el portal de noticias de manera que su público puede estar permanente actualizado. De esta forma busca llegar a más audiencia, a la vez que aumenta sus posibilidades de negocio, como el patrocinio de noticias o banners en la plataforma online. 


\section{4. $\mathrm{DN}+$}

El Diario de Navarra, es uno de los principales diarios de esta comunidad autónoma y líder de ventas en cuanto a prensa escrita en Navarra. Acapara más del $70 \%$ del mercado regional.

Diario de Navarra puso su web en marcha en 1998 y hace dos años aumentó su oferta informativa a través de la plataforma $\mathrm{DN}^{+}$, una plataforma de pago de contenidos exclusivos para los suscriptores, que incluye contenidos sonoros, visuales y multimedia para diferentes soportes.

Centrándonos en el contenido de audio de la web, la plataforma desarrolla un pódcast temático para cada día de la semana de lunes a viernes: los lunes uno deportivo sobre el Osasuna; el martes Con voz propia, un pódcast sobre crecimiento y bienestar; el miércoles El dardo, programa de análisis y opinión; el jueves $D N$ Running. para los amantes del running; y los viernes Nadie como mama, sobre maternidad.

El pódcast con contenido osasunista, Todo al rojo, dio origen a este tipo de contenidos, siendo el primero de la plataforma online del periódico. Este pódcast tiene su origen en la temporada 2016/2017, cuando nació Rojo contra rojo un programa semanal de cinco minutos de contenido similar, y que fue precursor del formato que hoy ofrece Diario de Navarra en sus diferentes temáticas.

En total, Diario de Navarra ofrece alrededor de 65 minutos semanales de contenidos de audio. Cuatro de los pódcast - a excepción de El dardose desarrollan con una duración de entre 10 y 15 minutos. El dardo, como su propio nombre indica, expresa la opinión de una manera mucho más directa y concisa, en una duración de entre 1 y 3 minutos.

El lenguaje, música y estilo de presentación de todos ellos es similar, una música a modo de sintonía al empezar y la palabra en vacío. Los pódcast comienzan con un indicativo que presenta el programa y a los locutores con música de fondo.

Todos los se difunden a partir de la plataforma $\mathrm{DN}^{+}$por suscripción y en redes sociales. En Twitter se presentan con el hashtag que llevan todos los contenidos de la plataforma de pago: \#SelecciónDN. 
Los oyentes pueden participar a través de la página de cada pódcast o en redes sociales. La primera edición de cada uno fue gratuita a través de la web de Diario de Navarra, a partir del segundo están únicamente disponibles por suscripción de pago.

Diario de Navarra desarrolla así una estrategia de negocio en la que ofrece contenido diferente y de calidad a cambio de una cuota mensual, trimestral o anual. Se trata de una nueva vía de financiación, en la que ofrece a sus suscriptores un contenido adicional al que disponen los demás lectores del papel y online.

La plataforma no solo amplía su oferta en cuanto a la posibilidad de consumir material sonoro, también amplía su oferta en reportajes escritos y material visual como fotos o vídeos.

Además de una nueva forma de negocio, también desarrolla una estrategia de captación de nuevo público. Diario de Navarra, consumido en su edición en papel por un público más adulto, presenta con su web y plataforma online la posibilidad de acceder a una audiencia más joven consumidora de información en otros soportes y formatos.

\subsection{Luces en el horizonte}

El programa Luces en el horizonte nació a su vez como contenido de radio en antena y podcasting. En 2012 se presentaba en una radio local de Pamplona a la vez que colgaba sus programas en la plataforma Ivoox.

Su temática: libros, discos, cine y televisión. Engloba a varios nichos de audiencia a la que le gusta un consumo de cultura relajado y distendido, de manera que su combinación de emisión directa en antena y asincrónica, lo hace perfecto para llegar a dos tipos de público diferentes pero complementarios. El oyente de radio en directo al que le gusta escuchar la radio nocturna, y la audiencia con un gusto específico de contenido, que lo busca y escoge a través del pódcast.

Siete años después, Luces en el horizonte sigue emitiendo en los dos formatos: antena y pódcast. Nominado varias veces a los Premios de la Asociación de Pódcast y a los premios Ignotus, galardón de la Asociación Española de Fantasía, Ciencia, Ficción y Terror; se encuentra entre los cien 
más escuchados de la plataforma líder en español para escuchar contenido en audio, Ivoox, con una media de 5.000 descargas semanales.

Uno de los aspectos más interesantes es cómo ha evolucionado desde el podcasting. Primero solo se difundían los programas emitidos en antena, después se pasó a elaborar especiales solo para el pódcast, ahora ha desarrollado diferentes líneas temáticas alrededor de este: episodios en antena, especiales, monográficos... incluso parte de los capítulos han sido recogidos en dos libros de ensayo.

Su difusión se realiza mediante la plataforma Ivoox, donde se puede descargar y acceder gratuitamente o por suscripción; las redes sociales propias en Facebook y Twitter; y el blog del pódcast, donde se puede disponer de suscripción a RSS.

Su estrategia de negocio es llegar al máximo número de público posible, consumidor y amante de dichas temáticas, un público fiel que espera el próximo episodio. Más audiencia significa más repercusión y difusión y, por lo tanto, más oportunidades de negocio para poder rentabilizarlo económicamente. El pódcast se financia a partir de patrocinios, publicidad en antena y la monetización en la plataforma Ivoox. La escucha del pódcast en Ivoox es gratuita pero permite monetizarlo con aportaciones de los oyentes.

Luces en el horizonte es un ejemplo de cómo sacar partido a un contenido sonoro online sin tener detrás una cadena o emisión en antena. La clave es encontrar una temática interesante para un público fiel y conseguir así el mayor número de difusión, descargas y escuchas por internet.

\section{CONCLUSIONES}

Cope.es destaca en su apuesta por el contenido $100 \%$ online, tanto a la hora de los noticias escritas en la web como es el contenido sonoro, donde con 24 pódcast $100 \%$ online genera grandes posibilidades para llegar a una audiencia de nichos fiel, que consume de temáticas específicas. 
Ondacero.es destaca por su compromiso a la hora de contar con la opinión del oyente, utilizando vías de comunicación alternativas como las redes sociales para llegar más cerca de la audiencia y recibir un feedback constante. En cuanto al contenido sonoro da un primer paso adelante con los pódcast $100 \%$ online, sobre todo en temática deportiva.

Cadenaser.com, por su parte, desarrolla su nueva web centrada en la convergencia de sus medios y plataformas. Destaca la plataforma Play SER creada para el almacenamiento, escucha, acceso y descarga de todos los contenidos sonoros de todas las emisoras de la Cadena SER en España. Hay que destacar la plataforma de podcast Podium Podcast, red de pódcast del Grupo Prisa, donde también se presentan los pódcast $100 \%$ online de la Cadena SER.

En definitiva, las tres cadenas apuestan por una radio que se ha hecho digital, interactiva y a la carta, e intentan potenciar sus posibilidades para ganar audiencia y crear nuevas oportunidades de negocio. Aunque todavía hay mucho camino que recorrer para aprovechar mejor las multiplataformas online.

Diario de Navarra es el medio más diferente, ya que en su medio de pago $\mathrm{DN}^{+}$, ha creado una plataforma en la que ofrece los tres formatos (escrito, vódeo y audio) para todos los soportes existentes (web, móvil y tabletas). Sobre todo, no solo lo hace nutriéndose de su medio nativo original, la prensa escrita, además propone contenido propio $100 \%$ online en todos los formatos.

Luces en el horizonte es un buen ejemplo de cómo un contenido nativo digital puede presentarse como alternativa competitiva a los medios tradicionales y, a partir de él, crear perspectivas de negocio más allá del formato original. Luces en el horizonte nació como un contenido sonoro online, y actualmente se difunde como pódcast online, en antena y en otros formatos, como el blog escrito o libros de ensayo, ampliando así su estrategia de negocio.

En conclusión, observamos cómo los medios tradicionales tienden a adaptarse al nuevo panorama digital. Todos tienden a encontrar nuevas forma de contenido, y a aprovecharlas como estrategias de negocio para ganar audiencia o financiación alternativa a la tradicional. 
Pero hay que ser constante. La digitalización e internet abren un mundo infinito de posibilidades pero también crean la «obligación» de adaptarse, para no quedarse atrás ante las nuevas formas de comunicación social emergentes.

El pódcast nativo o las redes sociales deben ofrecer un contenido de calidad y novedoso, que complete y se sume al contenido de los medios nativos tradicionales y que no solo duplique lo presentado en el formato original. Para aquellos medios no radiofónicos en origen producir contenido de audio original es, además de una oportunidad, un desafío al tener que desarrollar contenido en lenguaje diferente.

\section{BIBLIOGRAFÍA}

Cebrián Herreros, Mariano. 2008. La radio en internet. Buenos Aires: La Crujía.

Martínez Costa, P., E. Moreno y A. Amoedo. 2012. «La radio generalista en red: un nuevo modelo para la radio tradicional». Anagramas, 10, 20: 165-180. Colombia: Universidad de Medellín.

Moreno, Elsa. 2002. «El tratamiento radiofónico de la información local». En: Información Radiofónica: 339-350. Barcelona: Arial Comunicación. Rodríguez, Manuel J. 2016. «Medios de comunicación online y empoderamiento ciudadano: oportunidades y riesgo». Revista Internacional de Pensamiento Político - I Época, 11: 105-112. 


\section{INSIGHT TRASCENDENTE, TENDENCIAS ESPIRITUALES \\ EN PUBLICIDAD}

Samuel Gil Soldevilla

Universitat Jaume I

\section{Resumen}

El presente texto desarrolla la conceptualización de «insight trascendente» como conexión con el consumidor que supera la dimensión emocional. El humor, la seguridad, la emoción, etc., son insights aceptados y necesidades del consumidor. Desde una perspectiva diferente, ¿podría serlo también la necesidad de trascendencia? ¿Será realmente un precursor oculto para la venta o conexión con el consumidor?

Cuando hablamos del propósito de las marcas - por supuesto no de todas-, su objetivo ya no es responder a necesidades, ni siquiera crearlas, sino hacer converger visiones del mundo. La marca llega a representar todo el universo que el individuo puede alcanzar e interiorizar. De esta forma el consumidor poseería lo que podríamos denominar, utilizando un término propio del lenguaje publicitario, un «insight trascendente» que permite que se establezca esta relación simbólica entre la marca y su target. El sentido de trascendencia entendido como insight actuaría como catalizador velado detrás de algunos discursos persuasivos.

La tensión entre lo profano y lo espiritual es absorbida por la industria comercial, sumergiendo sus promociones en un baño de retórica trascendente, diluyendo en sus discursos la finalidad económica y concentrando sus esfuerzos en la generación de vínculos psicológicos, de creencias y espirituales («insight trascendente»). La industria y corporaciones, consciente y estratégicamente, permanecen en un segundo plano, dejando a la marca mediar entre los públicos consumidores y ser el foco visible de atención. A su vez, las agencias de comunicación enriquecen y dotan de contenido y sentidos a la marca a través de la publicidad. Cuando esta contiene significantes y significados de naturaleza 
espiritual, la marca pasa a participar de una esfera de intercambio no solo comercial sino trascendente.

Palabras clave: insight; publicidad; espiritualidad; marca; industria trascendente.

\section{CONCEPTO Y TIPOS DE INSIGHT}

$\mathrm{E}$

L TÉRMINO INSIGHT, PROVENIENTE DEL CAMPO de la psicología, se utiliza en publicidad sobre todo desde principios del siglo XXI y está relacionado con lo que se conoce como publicidad emocional, ya que explora las relaciones emotivas y afectivas en torno a qué incentiva el producto-marca en el consumidor (Bendezú Untiveros 2017).

Bill Bernbach, el hombre que lanzó «la revolución creativa» en la década de 1960 con una clase de publicidad con energía, estilo e ingenio, resumió así la esencia de la publicidad de una marca:

En el corazón de una filosofía creativa efectiva está la creencia de que nada es tan poderoso como una visión de la naturaleza humana, qué impulsos conducen a un hombre, qué instintos dominan su acción, a pesar de que su lenguaje a menudo pueda camuflar lo que realmente lo motiva. ${ }^{1}$

Es la comprensión de la naturaleza humana la clave de la habilidad del comunicador. Porque mientras que el escritor se preocupa por lo que pone en sus escritos, el comunicador se preocupa por lo que el lector obtiene de él. Por lo tanto, se convierte en un estudiante de cómo la gente lee o escucha. ${ }^{2}$

1. Original: «At the heart of an effective creative philosophy is the belief that nothing is so powerful as an insight into human nature, what compulsions drive a man, what instincts dominate his action, even though his language so often can camouflage what really motivates him».

2. Original: «It is insight into human nature that is the key to the communicator's skill. For whereas the writer is concerned with what he puts into his writings, the communicator is concerned with what the reader gets out of it. He therefore becomes a student of how people read or listen». 
Este concepto anglosajón se traduce actualmente como «percepción, perspicacia, darse cuenta de algo». El Cambridge Dictionary lo define como «(the ability to have) a clear, deep, and sometimes sudden understanding of a complicated problem or situation» y el Thesaurus Dictionary: «penetrating mental vision or discernment; faculty of seeing into inner character or underlying truth».

Su significado en el ámbito publicitario está relacionado con mirar hacia adentro, encontrar una verdad humana, "echar una mirada» al interior del consumidor, y utilizarlo como vínculo entre el público y marca. En definitiva, hace referencia a saber lo que pasa por la cabeza y corazón del target, entender lo que ocurre en la vida real del público, como ya señalaba Bernbach. Dicho vínculo, normalmente emocional, es una herramienta comunicativa estratégica que nos permite relacionar a las personas con la marca y su producto.

Para llegar hasta ese insight es necesario analizar al destinatario de la comunicación y ser capaz de vincular mediante el discurso su «verdad personal» con la marca. Aunque algunos insights nazcan de estudios sociológicos o métricas que desvelan una realidad no evidente o definida, otros son verdades comunes bien conocidas - que pueden ir cambiando con la evolución de la cultura, las comunidades, etcétera-. Por ejemplo, los monologuistas son especialistas en detectar insights del día a día y sacar provecho de ellos desde el humor.

Veamos algunos casos de campañas conocidas para ejemplificar este concepto:

- Campaña de verano (2011) de la agencia Sra. Rushmore para San Miguel 0,0. Insight: cuando te miran raro por pedirte una cerveza sin alcohol, o que la gente piensa que no te gusta la cerveza por beber 0,0 . El eslogan utilizado, desde el humor y el propio producto: «La 0,0 de los cerveceros».

- Campaña Apple (1997). Insight: las personas que marcaron la historia fueron cuestionadas por haber pensado distinto. El eslogan utilizado, desde la historia: «Think different». 
- Campaña internacional Dove (desde 2004). Insight: las modelos y actrices no representan a la media; la imagen de la mujer se está desvirtuando y muchas tienen una baja autoestima como consecuencia. El eslogan utilizado, desde la autoestima: «Campaña por la belleza real. Mujeres reales, curvas reales». En este caso, Dove se inspiró en «The Real Truth About Beauty: A Global Report», un estudio realizado por investigadores de Harvard a $3.000 \mathrm{mu}-$ jeres en diez países (2004, solicitado por la empresa). En 2010 se estableció una nueva visión de la marca a través del Movimiento Dove por la Autoestima: La Fundación de Dove, que pretende actuar como agente de cambio para inspirar y educar a las mujeres en una definición más amplia de la belleza.

El humor, la necesidad de seguridad, la adrenalina, la emoción, la tradición, la familia, etcétera, son áreas del ser humano desde las que encontramos numerosos insights utilizados por agencias creativas y marcas. Tomando una perspectiva diferente y más profunda, ¿podría serlo también la necesidad de trascendencia? ¿Será realmente un precursor oculto para la venta o conexión con el consumidor? ¿Hay marcas que hagan uso de este tipo de insight? ¿A qué nos referimos con «insight trascendente»?

\section{HACIA UN DISCURSO PUBLICITARIO TRASCENDENTE}

\subsection{La espiritualidad de la marca}

George Lewi, mitólogo y experto en marcas, asegura que «los consumidores de hoy tienen tanta necesidad de creer en sus marcas como los griegos en sus mitos» (Salmon 2007, 61). Las marcas han adquirido un papel esencial en la vida de las personas más allá de su carácter mercantil, situándose como constructoras de significado, haciendo converger visiones del mundo y dando sentido a la realidad.

En 1994 la revista Advertising Age avisaba que tendrían éxito aquellos vendedores que entendiesen y conociesen las necesidades de esperanza, 
realización personal y renovado sentido espiritual que los consumidores norteamericanos buscaban. Allison Cohen, presidente de la consultora de marketing People Talk añadía que las temáticas espirituales iban a estar más presentes en la publicidad (Rickard, 1994).

Naomi Klein aplica esta idea en su conocidísimo libro No logo al decir que «las marcas son vendedoras de significado, no de artículos de consumo [...]. En el nuevo modelo, el producto siempre es secundario respecto al producto real, que es la marca, y la venta de la marca integra un nuevo componente que solo se puede denominar espiritual» (Klein 2007, 55). Vicente Verdú describe de forma brillante esta nueva dimensión:

... la marca se comporta como un soplo espiritual. Su condición de intangible posee un poder simbólico que se insufla aquí y allá como un espíritu santo del capitalismo capaz de convertir productos en ideologías, de manera que relacionarse con unas determinadas marcas es optar por una ilusión de la vida, porque la marca no viene solo a tatuarse sino a alentarnos. (Verdú 2003, 125).

El gurú internacional del marketing, Martin Lindstrom, añade que «en realidad, estas astutas marcas no están vendiendo comida, ni perfume, ni maquillaje; están vendiendo pureza, espiritualidad, fe, virtud y, en algunos casos, expiación» (Lindstrom 2011, 246). Por eso cuando hablamos del propósito de las marcas - por supuesto no de todas-, «ya no se trata de seducir o convencer, sino de producir un efecto de creencia» (Salmon 2007, 63).

Tanto es así que la tendencia en la dirección de comunicación camina hacia la «construcción de creencias compartidas» según el Corporate Excellence y la Arthur W. Page Society, esta última es la asociación norteamericana que agrupa a los directores de comunicación de las principales empresas del Fortune 500 en Estados Unidos. Su planteamiento consiste en un nuevo modelo donde «la identificación de los stakeholders con las marcas y la de estas con sus stakeholders puede ser posible si se construye conjuntamente un corpus de creencias verdaderamente compartidas y creadas en común» (Excellence 2015). A partir del énfasis en la identidad (propósito, sentido de la organización, 
visión y valores) la cual se encuentra en el centro del modelo, surgen las creencias de la organización.

Y la tendencia aumenta: «en la actualidad, del conjunto de las religiones alternativas, las marcas se han convertido en unos serios competidores de quienes proporcionan creencias, significados, sentimientos de comunidad e identidad» (Atkin 2008, 224). A medida que las marcas se vayan sofisticando, se convertirán en mayor fuente de comunidad y significado, y más convincentes se volverán. Esto viene a confirmar lo declarado por la agencia global Young \& Rubicam en un reportaje para la revista Financial Times (Marzo, 2001): «las marcas son la nueva religión. Las personas acuden a ellas en busca de significado» (Tomkins 2001). El objetivo ya no es responder a necesidades, ni siquiera crearlas, sino hacer converger visiones del mundo. La marca representa todo el universo que el individuo puede alcanzar e interiorizar.

De esta forma el consumidor poseería lo que podríamos denominar, utilizando un término propio del lenguaje publicitario, un «insight trascendente» que permite que se establezca esta relación simbólica entre la marca y su target. El sentido de trascendencia entendido como insight actuaría como catalizador velado detrás de algunos discursos persuasivos.

Las empresas han emprendido su búsqueda por generar deseo por sus marcas y productos impregnándolos de cualidades «espirituales» tan intangibles aunque emocionalmente atractivas como la salud, la esperanza, la felicidad, la fe, la pureza, la buena suerte e, incluso, la mejora del alma humana. Esta tendencia psicológica universal es lo que hace muy poderosos a los persuasores ocultos. (Lindstrom, 2011, 228).

Es la que hace que el metamensaje publicitario sea posible y aceptado por el consumidor como una realidad tangible, que se expresa en su vida. Este sentido de trascendencia, vinculado profundamente con las emociones, sería utilizado por las marcas para conferir sentido a la vida a través de productos y discursos que, armados de un lenguaje misteriológico y sobrenatural facilitado por la espectacularidad de la técnica audiovisual, otorgan respuestas al ser humano y satisfacen su 
necesidad de pertenencia y sentido. De esta manera se integra un nuevo componente proponiéndoselo al consumidor: una esencia intangible y espiritual.

La publicidad no es ya un mero instrumento del capitalismo, es un vehículo de trascendencia, «medio portador de un metamensaje» dotando al producto físico de alma - «animismo mercadológico o comercial» (León 2001, 59)-, y consiguiendo que esa trascendencia nos haga sentir superiores, capaces, aptos. «La ambición del marketing del siglo XXI ya no se detiene a las puertas del supermercado, sino que abarca el mundo entero. Ya no tiene solo por ambición promover las ventajas de la sociedad de consumo, quieren «producir» una sociedad nueva, otro mundo. Ya no oculta su carácter mesiánico...» (Salmon 2007, 60). ${ }^{3}$

¿Quién nos iba a decir que AXE, una marca de desodorante masculino, haría una campaña de enorme repercusión social entorno a la idea Make love. Not war, anunciando su nueva línea de producto AXE PEACE, bajo el hashtag \#kissforpeace y con el objetivo de «generar un cambio pacífico en el mundo beso a beso»? ${ }^{4}$ (figura 1).

3. «En una sociedad guiada por los símbolos de las marcas, resultaría extraño que no hubiera «mesías comerciales» tratando de llevar a cabo su papel de receptáculos de significado» (Atkin 2008, 142).

4. Véase http://www.axepeace.com y http://www.peaceoneday.org/axe-peace. En esta última web explican su propósito, el cual deja claro la dimensión ideológica que defendemos en este punto: «With a shared vision of bringing young people together to make the world a better place, in 2014 we'll be encouraging guys and girls to make love, not war, through a series of simple but meaningful actions». Su proyecto es crear una plataforma de gente joven para que juntos influencien positivamente sus comunidades. Su campaña será lanzada en más de cincuenta países, servirá para dar fuerza a esos jóvenes y mejorar el mundo en el que vivimos a través de sencillas pero poderosas acciones de amor y paz. En España también han iniciado su campaña http://www.axe.es/peaceone-day y el 14 de febrero de 2014 presentaron el 1.er Estudio «Haz el amor y no la guerra» donde «demuestran» que los jóvenes españoles forman parte de la generación con mayor conciencia social; también llevaron a cabo acciones en la calle y talleres gratuitos sobre «Haz el amor y no la guerra en pareja». La marca aseguró que pondría en marcha diferentes experiencias a lo largo del año con el objetivo de movilizar a la sociedad española con la causa de Peace One Day. 

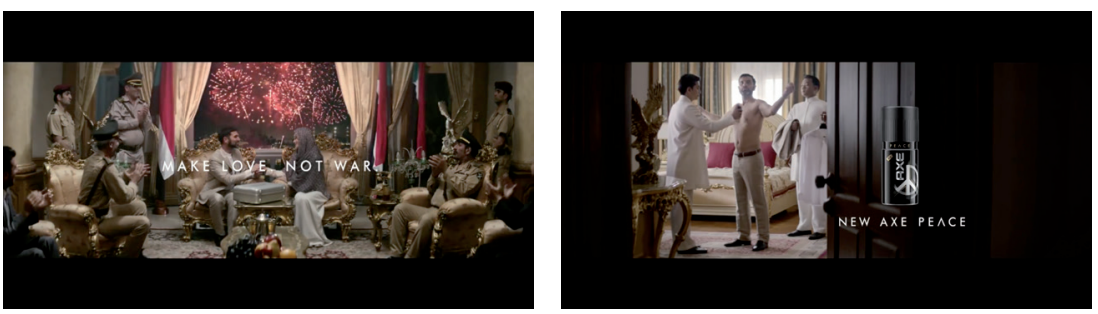

Figura 1. Representación ideologías en publicidad (1)

Fuente: AXE. «Make love. Not war» (2014). Fotogramas spot.

¿Por qué una marca de chocolate querría transformar el mundo ${ }^{5}$ (figura 2).
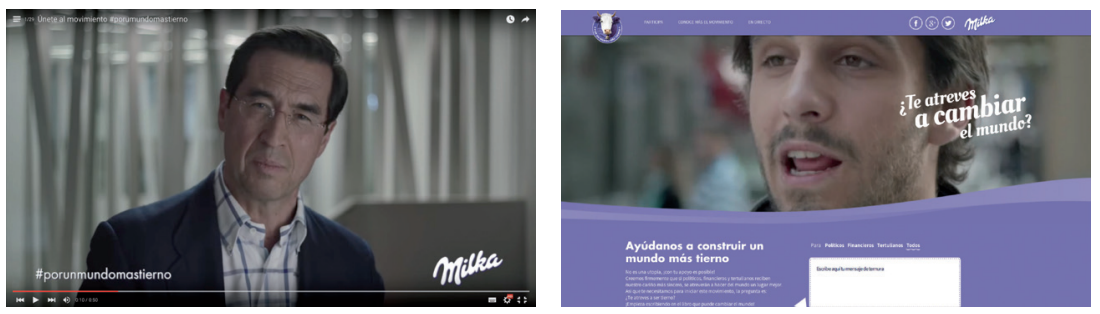

Figura 2. Representación ideologías en publicidad (2)

Fuente: Milka. \#porunmundomastierno (2014). Captura Web.

5. El doctor Mario Alonso Puig, embajador del movimiento, explicaba y respaldaba la relación que hay entre la ternura y la mejora de la sociedad: «Todo lo que sea traer un poco más de cercanía, de benevolencia, de ternura y de compasión a nuestras vidas va a tener un impacto muy importante en nuestro bienestar, en nuestro nivel de felicidad, y además en el progreso real que esta sociedad alcance». El proyecto ofrecía la posibilidad de enviar mensajes a través de porunmundomastierno.com y de las redes sociales con el hashtag \#porunmundomastierno. Con todos los textos recibidos se editó en 2014 un libro llamado el Código de la ternura, el cual se entregó a políticos, líderes financieros y tertulianos televisivos. El movimiento no sigue activo, desvelando la fugacidad ideológica de las marcas una vez sus campañas cumplen sus objetivos. 
¿Desde cuándo unas zapatillas nos guían hacia la autosuperación y la autorrealización $?^{6}$ (figura 3).
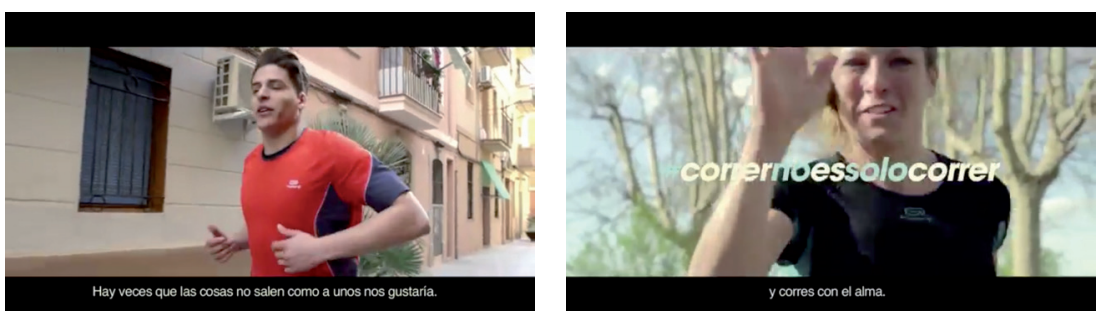

Figura 3. Representación ideologías en publicidad (3)

Fuente: Decathlon. \#corrernoessolocorrer (2014). Fotogramas spot.

¿Desde cuándo una marca define lo que es o debe ser la vida? ¿No se ocupaban de eso la política, la filosofía o incluso la teología? Hoy en día no son pocas las marcas cuyo mensaje y eslóganes comienzan con «Life is...» (figura 4).
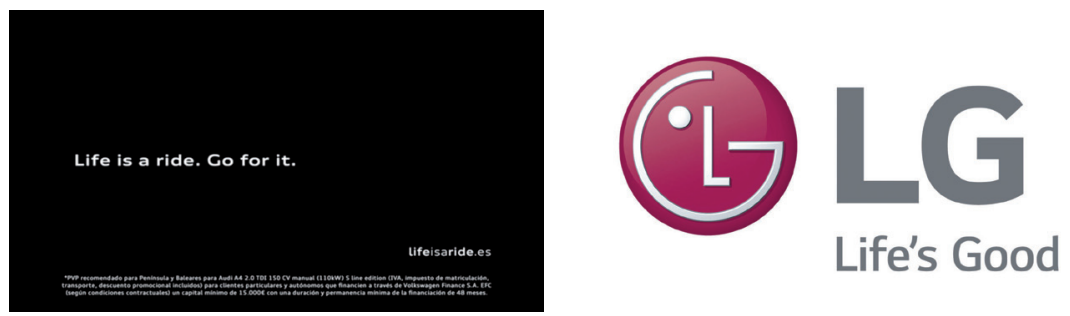

Figura 4. Representación ideologías en publicidad

Fuente: Audi. «Life is a ride. Go for it» (2014). Fuente: LG. «Life is good» (2014).

6. Decathlon lanzó un vídeo de dos minutos entre abril y mayo (2014) para su campaña de Operación Running bajo el eslogan \#corrernoessolocorrer. El spot finalizaba con la siguiente frase, después de contarnos las historias personales y superacionales de varios corredores: «No solo corres con las piernas. Corres con el corazón y corres con el alma». La marca utiliza los discursos y experiencias vitales de diferentes personas para trascender un producto e incluso al deporte, y convertirlo en una forma de entender la vida a través de la marca. 


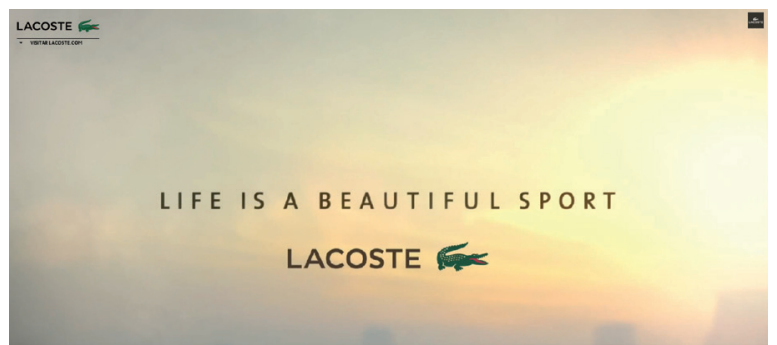

Fuente: Lacoste (The big leap). «Life is a beautiful sport» (2014).

\subsection{Intangibles: la venta de lo invisible}

Con unos valores tangibles agotados por la superabundancia de la productividad, la indiferenciación material y la saturación de mensajes similares, la solución llega de los valores intangibles y su aportación como valor diferencial en un territorio competitivo. Finalmente nos encontramos con que la creación y gestión de la marca es

una faceta de lo que llamamos la gestión de los intangibles. Porque lo que se gestiona, de hecho, está más allá -y va más lejos-de los productos, su materialidad, su utilidad y las prestaciones que les ofrecen a los consumidores y la satisfacción que estos sienten. Lo que se gestiona es, tal como hemos visto, más que la marca. Es su imago. [...] Los intangibles de la marca son aquellos conceptos como el simbolismo, el significado, el discurso emocional, los mensajes, la identidad, la personalidad, la cultura, la reputación, el lado social. (Costa 2004, 195).

El concepto de intangible es un elemento importante en el anclaje de la naturaleza trascendente de la marca porque expresa su «más allá», su fundamento inmaterial, su naturaleza espiritual. Es interesante al menos notar que, aunque el sentido en el que actualmente las empresas lo toman no es en su vertiente religiosa como dimensión cargada de significado sino con un sentido empresarial, se admite que hay algo más difícilmente manejable y que supera su propio objeto.

Es entonces cuando, como destaca Eguizábal $(2009,16)$, los principios publicitarios sustituyen en nuestras sociedades a los principios 
religiosos y políticos. Es cuando desaparece el valor real del producto -sus ingredientes, sus propiedades, su valor de uso- para sustituirlo por el valor imaginario - su capacidad de representación, su valor simbólico-. Los anuncios hablan menos de las mercancías y más de las personas, no tanto de las propiedades de un producto, como de lo que el consumidor necesita y de sus deseos, fabricando en él una conciencia de sus insuficiencias y anhelos. Los bienes materiales se convierten «en metasignos, porque significan mucho más allá del estricto espacio mercantil. [...] Toda mercancía es un evento simbólico antes que funcional» (Alonso 2005, 291, 295). En este punto se encuentra la publicidad actual, una publicidad centrada en lo inmaterial.

La marca, uno de los elementos intangibles más reconocidos de la empresa -véase La imagen de marca: un fenómeno social-, ha acumulado sus antiguos estados: es al mismo tiempo signo, discurso y sistema de memoria. Pero también las marcas son muchas cosas más: objetos de deseo, seducción, fetiches, sujetos de seguridad, autorrealización y hasta espejos idealizados en los que los individuos ven ilusoriamente proyectada su autoimagen; llegando a decir con Costa que «la marca puede llegar así a la sublimación y al éxtasis» $(2004,113)$. Es cierto que la marca no nace en abstracto, puesto que su discurso comienza con el producto/servicio, pero sí camina hacia lo abstracto, forjándose la imagen de marca y enriqueciéndose psicológicamente con el paso del signo al símbolo.

Joan Costa lo sintetiza en un gran arco que representa la evolución desde el signo (fenómeno sensorial) a la imagen -imago- mental (estereotipo abstracto y psicológico). La figura representa grupos concretos de productos, aunque todos ellos pueden estar teñidos de cualquier tipo combinatorio de sensaciones, y el proceso desde lo funcional hasta lo emocional de la marca a la imagen mental, el cual se produce en la psicología del consumidor. La implicación emotiva aumenta a medida que la intensidad psicológica se apropia de la marca. Pero queremos apuntar hacia un estadio más allá incluso del símbolo que hemos definido como metamensaje (figura 5). 


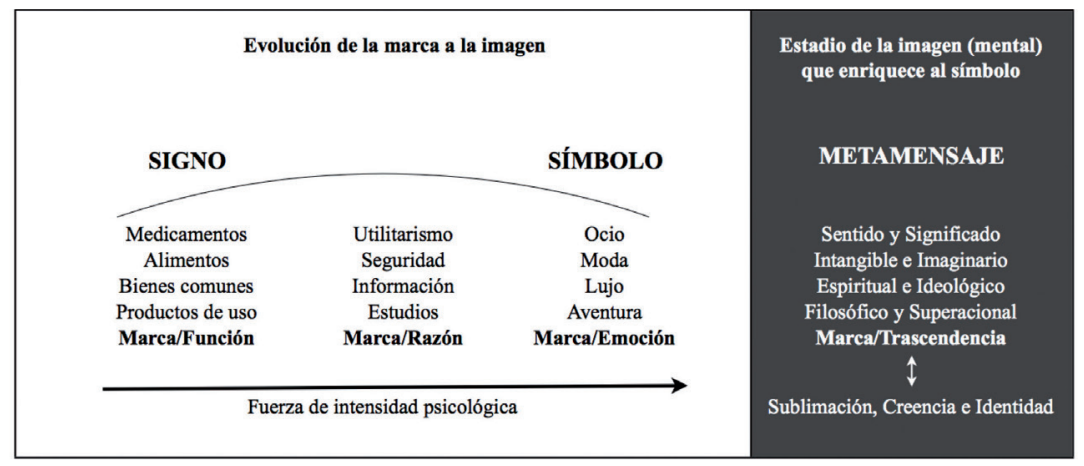

Figura 5. Arco evolutivo de la marca al metamensaje Fuente: (Costa 2004, 116). La parte gris es nuestra propuesta añadida.

Si bien la marca/función deviene en marca/emoción cuando se enriquece con valores que se suman en la imagen mental, la marca/emoción se convierte en marca/trascendencia cuando el símbolo se convierte en metamensaje, esto es, cuando la fuerza psicológica transmitida por la marca y su discurso, e implantada en la mente del consumidor (no nos olvidemos que la imagen es un producto psicológico que no está en manos de la empresa), traspasa las emociones (lovemarks) y alcanza la reflexión vital del individuo y colabora en la formación de su programa existencial («marcas de culto» e «industria trascendente»). Se genera, por tanto, cuando las marcas se erigen como constructoras de significado, convergen visiones del mundo y proporcionan sentido a la realidad.

Si bien el signo es la expresión general de lo funcional y el símbolo la expresión profunda de lo más emocional, el concepto de metamensaje debemos entenderlo como la expresión trascendente de lo ontológico (rol que toma la marca), en tanto en cuanto la marca y su discurso también tratan el ser de las cosas y lo humano, y su relación con la realidad. Esto supera la marca/emoción y enriquece al símbolo. Cuando la fuerza psicológica conquista las creencias e identidad del consumidor, ofreciéndole sentido y significado desde perspectivas de orden interior (intangible e imaginario, espiritual e ideológico, o filosófico y superacional), entonces el símbolo se convierte en metamensaje. 
La marca deja de ser un simple signo de identidad y reconocimiento asociado al producto para instalarse en lo más psicológico del imaginario social. Ahí se convierte en un referente -un auténtico estereotipo cultural-, en la medida en que esa imagen está cuajada de aspiraciones representadas por ella, de satisfacciones y emociones, y es símbolo de pertenencia a un grupo, a un estilo de vida, de encarnación de una idea, de un nexo social o cultural de identidad, de un estatus... (Costa 2004, 151).

\section{CONCLUSIONES: ¿QUÉ ENTENDEMOS POR INSIGHT TRASCENDENTE?}

Este texto parte de una definición de religión funcionalista (qué hace) en vez de sustantiva (qué es), y lo hace desde su dimensión comunicativa al entender la religión no solo como un tipo de institución social o sistema de sentido individualizado, sino como una «conversación social sobre significados/sentidos trascendentes» (Besecke 2010, 92, 105). Pero, ¿qué entiende por «significados trascendentes»? Se refiere a un contexto de vida que existe en un plano más allá («trascendente») de la realidad aparente, y que como otros significados, estos son producto de la interacción y la comunicación (no surgen de manera individual ni son exclusivos de la institución). Esta definición nos permite, al menos, «comenzar a comprender la "religión" que tiene lugar en entornos "seculares" como librerías, salas de conferencias, cines y cafés», y añadimos: también en la publicidad. Así, podemos considerar el discurso publicitario como parte de esa conversación sobre significados trascendentes. Para Besecke,

tiene sentido repensar dónde localizamos la religión, es decir, no solo en las iglesias y otras organizaciones y no solo en la esfera privada de la psique individual, la familia o incluso las relaciones cercanas. La religión radica en la comunicación, en la conversación. La religión entendida institucionalmente se parece a una iglesia, secta o culto; la religión mirada individualmente se ve como orientaciones psicológicas y la creencia ocasional. Mirada culturalmente, la religión parece una conversación, una conversación social sobre significados trascendentes.(Besecke 2010, 105). 
Esta conceptualización nos permite escapar de etiquetas demasiado estrictas e inoperantes ante la proliferación y revitalización de nuevas formas espirituales encauzadas por la posmodernidad (Aupers y Houtman 2010, Heelas 2005, Lenoir 2003, Lipovetsky 2007, Mardones 2000 y Taylor 2014). Términos como «religión implícita» (Borg Ter 2004, Parna 2010 y Porter 2009), «pequeñas trascendencias» 0 «weak trascendence» (Hervieu-Léger 2005, 62, Luckmann 2003, 2008, Mardones 1996 y Nelson 2009), se convierten en herramientas analíticas apropiadas y ofrecen un marco adecuado para pensar la publicidad no solo como industria cultural, sino como «industria trascendente», y por tanto pensar el término insight desde ahí.

Aunque no es el objetivo de esta investigación, la siguiente propuesta de síntesis de ocho tipos de discurso publicitario nos puede servir también para localizar esta nueva categoría persuasiva de insight trascendente. Podemos encontrar diferentes insights comunicativos que pueden englobarse dentro de cada uno de estos tipos de discursos (véase la figura 6). Son insights centrados en:

- Producto: utiliza una característica relevante del producto relacionada con un insight del público para establecer el vínculo: el ejemplo visto al comienzo de San Miguel 0,0.

- Racional: se enfoca en áreas personales del target que tienen que ver con necesidades racionales: la seguridad al volante, a modo de ejemplo.

- Promesa: satisface la idea de mejora o bienestar futuro del consumidor: todo spot contiene una promesa, pero nos referimos aquí a aquellos discursos que usan un insight que apela explícitamente a ese sentimiento humano de prosperidad, relacionado con el producto/marca.

- Valores sociales: funciona a través de insights vinculados a estilos de vida, valores comúnmente aceptados o característicos de una comunidad hacia la que se dirige el mensaje: como ejemplo, la campaña de Coca-Cola con parejas homosexuales que han adoptado un niño/a (2015). 
- Emocional: aborda insights de carácter emotivo, hacia la dimensión personal, íntima y apelativa del espectador.

- Inspirador: ejerce su influencia desde un insight de naturaleza más psicológica y aspiracional que emotiva, le aporta sentido y significado al target: el caso de la campaña de Apple vista al comienzo del texto.

- Creencias o comportamientos: se focaliza en insights relacionados con el comportamiento o las creencias para vincularse o generar cambios en la experiencia del público: por ejemplo, el autoestima citado previamente en la campaña de Dove.

- Trascendente: toma la necesidad de sentido vital, la cosmovisión del individuo, y se adhiere a ella, la llena o la transforma. Relacionado con una impresión de plenitud, éxtasis o profundidad personal.

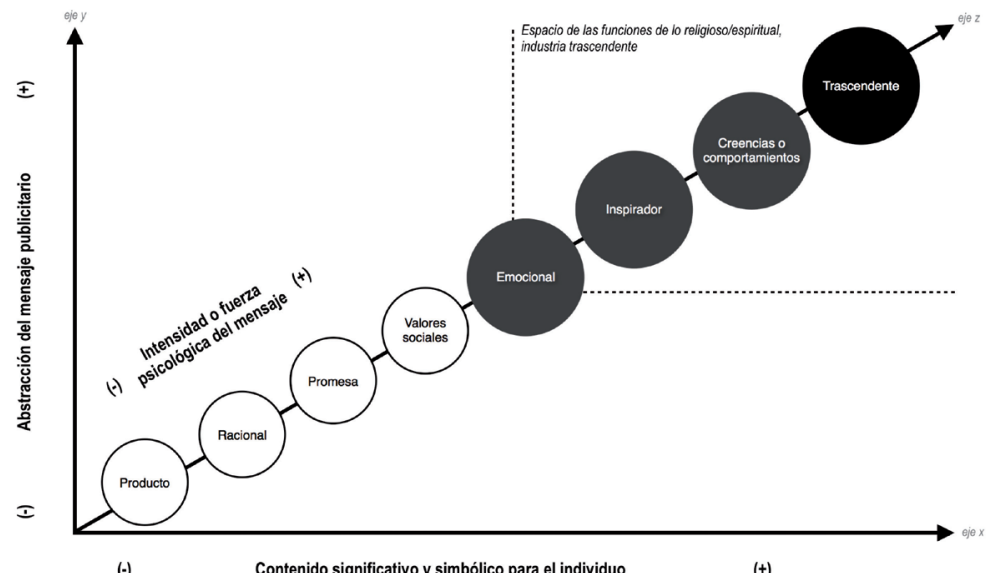

$(-)$

$(+)$

Figura 6. Tipos de discurso publicitario y naturaleza de los insights Fuente: Elaboración propia

Una marca adquiere un rol trascendente o entra en las funciones de lo espiritual cuando la fuerza psicológica transmitida por su discurso alcanza la reflexión vital del individuo y colabora en la formación de su 
programa existencial; a esto llamamos «insight trascendente». Es decir, cuando se propone al espectador una experiencia superior que pueda orientar y transformar su visión de las cosas o su relación con el mundo. Sin ser necesariamente sobrenatural, carga de atributos supra-materiales a objetos o individuos, infunde en el producto, servicio o marca una imagen que lo trasciende, transmite una sensación más profunda, lleva a pensar en algo más grande que uno mismo y su discurso contiene formas espirituales. Por tanto, definimos «industria trascendente» como aquella industria comunicativa que crea, difunde y reproduce mensajes para los públicos de interés de una empresa o sus consumidores, y que se caracteriza por ir más allá de su función principal como vehículo de promoción de productos o servicios -aunque conserve esta finalidad-, incorporando en su comunicación elementos espirituales (figura 7).
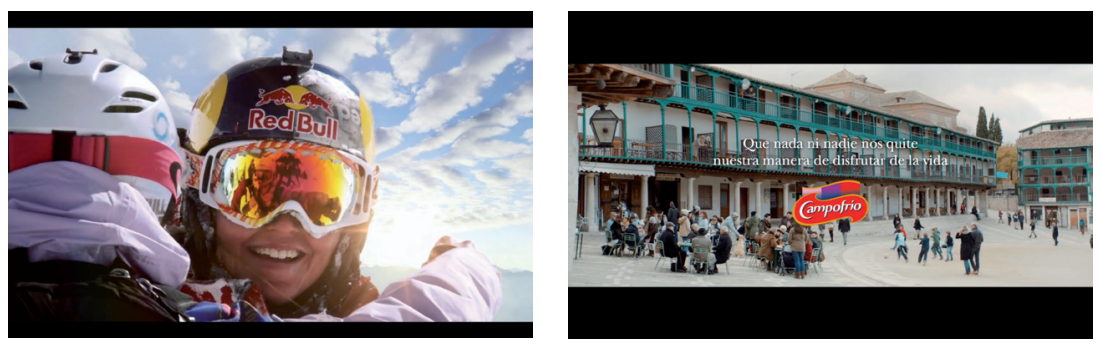

Figura 7. Spots considerados espiritualmente densos. Ejemplo de insight trascendente.

Fuente: World of RedBull (2012) y Campofrío: Despertar (Navidad 2015).

En este sentido, debemos matizar que tras el análisis de dos campañas consideradas espiritualmente densas a modo de ejemplo de este tipo de insight trascendente, podemos decir que lo que plantea el contenido de los spots no es una religión como tal ni una trascendencia profunda, sino rasgos de una espiritualidad separada de instituciones tradicionales que inciden especialmente en cuatro características: destaca el potencial humano y la capacidad de lograr lo que te propongas, hace pensar en lo importante que es vivir el presente como espacio de oportunidad, invita 
a afrontar lo negativo y a transformar las dificultades en oportunidades y estimula la búsqueda de la felicidad o de la plenitud personal. Por tanto, la trascendencia a la que nos referimos no es más (ni menos) que una publicidad asociada a una espiritualidad no teísta, naturalizada e interior, orientada hacia narrativas del yo y la autosuperación de la vida cotidiana, como trascendiéndola.

Los estudios de mercado y los consumer insights han sabido guiar a las marcas en el proceso colonizador de nuestra atención cotidiana, aunque no están solas, pues los consumidores experimentamos el mundo a través de los mensajes mediáticos y participamos de su mirada como sus cómplices. La industria de la publicidad adora los fenómenos que absorben el máximo de nuestra atención y está dispuesta a recurrir a los temas que sean necesarios, dando una impresión de profundidad, aunque realmente banalice lo trascendente o no plantee nada verdaderamente relevante y transformador en el plano humano, social o político. La esencia de las narrativas neoliberales es superficial; por ende, el plano espiritual queda reducido a la inmanencia de las cosas, a un mero consumible, aunque este se recubra de un mensaje audiovisual poderoso.

\section{BIBLIOGRAFÍA}

Alonso, L. E. 2005. La era del consumo. Madrid: Siglo XXI.

Álvarez, C. 2010. Hacia un Nuevo Modelo de Valoración de Intangibles. Castellón de la Plana: Universitat Jaume I.

Atkin, D. 2008. El secreto de las marcas. Barcelona: Robinbook.

Aupers, S. y D. Houtman (eds.). 2010. Religions of Modernity: Relocating the Sacred to the Self and the Digital. Boston: Brill.

Bendezú Untiveros, R. 2017. «El efecto "insight” en el discurso publicitario». Revista chilena de semiótica, 6: 26-43.

Besecke, K. 2010. «Seeing Invisible Religion: Religion as Societal Conversation About Trascendent Meaning». En Religions of Modernity: Relocating the Sacred to the Self and the Digital, 89-114, eds. S. Aupers y D. Houtman. Leiden: Brill. 
Borg Ter, M. 2004. «Some Ideas on Wild Religion». Implicit Religion, 7, 2: 108-119.

Costa, J. 2004. La Imagen de marca: un fenómeno social. Barcelona: Paidós.

Eguizábal, R. 2009. Industrias de la conciencia: una historia social de la publicidad en España (1975-2009). Barcelona: Península.

Excellence, C. 2015. «Construir creencias compartidas: el papel del Dircom en la Comunicación Corporativa del futuro». En: Insights \& Trends - Documentos de Estrategia. http://cort.as/-E6Gr

Heelas, P. 2005. The Spiritual Revolution: Why Religion Is Giving Way to Spirituality. Massachusetts: Blackwell Pub.

Hervieu-Léger, D. 2005. La religión, hilo de memoria. Barcelona: Herder. Klein, N. 2007. No logo. Barcelona: Paidós.

Lenoir, F. 2003. Las Metamorfosis de Dios: la nueva espiritualidad occidental. Madrid: Alianza.

León, J. L. 2001. Mitoanálisis de la publicidad. Barcelona: Ariel.

Lindstrom, M. 2011. Así se manipula al consumidor. Barcelona: Gestión 2000.

Lipovetsky, G. 2007. La felicidad paradójica. Barcelona: Anagrama.

Luckmann, T. 2003. "Transformations of Religion and Morality in Modern Europe». Social Compass, 50, 3: 275-285.

—. 2008. Reflexiones sobre religión y moralidad. En El fenómeno religioso. Presencia de la religión y de la religiosidad en las sociedades avanzadas, 15-26, ed. E. Bericat Alastuey. Sevilla: Centro de Estudios Andaluces.

Mardones, J. M. 1996. ¿A dónde va la religión?: cristianismo y religiosidad en nuestro tiempo. Santander: Sal Terrae.

- 2000. Para comprender las nuevas formas de la religión: la reconfiguración postcristiana de la religión. Navarra: Verbo Divino.

Nelson, J. M. 2009. Psychology, Religion, and Spirituality. Valparaiso: Springer.

Parna, K. 2010. «The Implicit Religiosity of the Millennium Bug Scare». En Religions of Modernity: Relocating the Sacred to the Self and the Digital, 239-259, eds. S. Aupers y D. Houtman. Leiden: Brill. 
Porter, J. 2009. «Implicit Religion in Popular Culture: the Religious Dimensions of Fan Communities». Implicit Religion, 12, 3: 271-280. Rickard, L. 1994. Spirituality, hope on horizon of solace sought.

Salmon, C. 2007. Storytelling: la máquina de fabricar historias y formatear las mentes. Barcelona: Península.

Taylor, C. 2014. La Era Secular. Tomo II. Barcelona: Gedisa.

Tomkins, R. 2001. Brands Are the New Religion. http://cort.as/-E6H6

Verdú, V. 2003. El estilo del mundo: la vida en el capitalismo de ficción. Barcelona: Anagrama. 


\section{LOS INFLUENCERS EN LA COMUNICACIÓN LOCAL}

FRANCISCO JimÉNEZ RUIZ

Universitat Jaume I

\section{Resumen}

El influencer marketing, o la implementación de estrategias de marketing digital basadas en la colaboración de ciertas celebrities o personalidades con el fin de conseguir objetivos concretos como la venta, la interacción (llamado engagement) o simplemente la generación de tráfico; convence ya a seis de cada diez directores de marketing, según el último estudio de LaunchMetrics.

Pero ya no es necesaria la contratación de ese perfil millonario en seguidores, sino que utilizan a los llamados microinfluencers, o personas relevantes en algún ámbito por el que son contratados por las marcas, para contar de una manera natural, cercana, amena y con toda esa información que te hará comprender la necesidad de comprar eso que promueve. Estos perfiles no venden sin más, sino que aportan valor a un nicho determinado de personas a los que resulta útil y significativo escucharle. Los microinfluencers hablan e influyen en las decisiones de compra. Este aumento de predisposición por parte de consumidores de canales sociales a seguir las recomendaciones de esos microinfluenciadores sigue creciendo. Este dato no pasa desapercibido para las empresas y marcas con menores recursos o enfocadas a un área geográfica determinada, y cada son más las que se suben al carro y realizan acciones locales con influencers expertos en un tema concreto o con mucho tirón en una zona concreta.

Por tanto se pretende enfocar el documento desde un punto de vista de empresas regionales que puedan estar interesadas en este tipo de campañas.

Palabras clave: influencer, microinfluencer, redes sociales, marketing, brand content. 


\section{INTRODUCCIÓN}

7 Ienen miles de seguidores y sus apariciones en público son un auténtico fenómeno de masas. Sus bromas, juegos, comentarios o

consejos tienen una repercusión inmediata y acaparadora. Su capacidad e influencia a través del ocio y el entretenimiento puede ser enorme. Son influencers, gente que realiza y emite a través de sus redes sociales contenido propio y personal, y que tienen miles de seguidores.

Los contenidos pueden ser muy diversos, y la red los amplifica hasta límites impensables, llegando a convertirlos, a veces, en una auténtica mina de oro para algunas marcas de gran consumo.

El influencer marketing, o la implementación de estrategias de marketing digital basadas en la colaboración de ciertas celebrities o personalidades con el fin de conseguir objetivos concretos como la venta, la interacción (llamado engagement) o simplemente la generación de tráfico; que según el estudio de Launchmetrics de abril de 2018, convence ya a seis de cada diez directores de marketing.

Pero en este mundo globalizado y accesible, ¿cómo aprovecha esta influencia global las marcas de ámbito local? ¿Existen esas figuras de influencia en un ámbito local de comunicación? Existen los llamados microinfluencers, que según varios blogs de comunicación, como BusinessGo.com; 40defiebre.es o Puromarketing.com; son personas relevantes en algún ámbito por el que son contratados por las marcas, para contar de una manera natural, cercana, amena y con toda esa información que hará comprender la necesidad de comprar eso que promueve. Estos perfiles no venden sin más, sino que aportan valor a un nicho determinado de personas a los que resulta útil y significativo escucharle. Los microinfluencers hablan e influyen en las decisiones de compra. No tienen un volumen de seguidores como sus «hermanos mayores», los influencers, pero sí gozan de una credibilidad increíble por parte de sus followers, con ratios de engagement muchísimo más elevados.

En definitiva, son usuarios expertos en una temática muy concreta que comparten su pasión, opinión y conocimiento en sus perfiles de sus 
redes sociales logrando resultados de 3 a 5 veces mejores en cuanto a engagement por cada post.*

Sin embargo, este nuevo escenario ha provocado que muchos de esos supuestos influencers se hayan aprovechado de esta tendencia para comprar seguidores falsos, y de esta manera «ostentar» perfiles con miles de seguidores, mayoritariamente ficticios con el objetivo de que las marcas se fijen en ellos y les encarguen campañas pagadas.

Las alertas han saltado y ya hay muchas marcas que están retrocediendo y evitando contratar influencers.

\section{OBJETIVOS}

Los objetivos principales de este trabajo son:

- Profundizar sobre la tendencia de las marcas respecto a los influencers haciendo especial hincapié en el terreno de la comunicación local.

- Al mismo tiempo, este trabajo se plantea una reflexión sobre la adecuación estratégica que tiene incluir la figura del influencer marketing dentro de la comunicación local.

- Finalmente, proponemos determinar las principales claves para hacer un buen uso de la utilización de los influencers en la comunicación de las marcas.

\section{METODOLOGÍA}

Esta investigación está fundamentada en una metodología esencialmente cualitativa, para la que se ha aplicado, por un lado, una recopilación de contenido y búsqueda bibliográfica relacionada con la temática a tratar. Dicha búsqueda se ha centrado en medios de comunicación generalistas, artículos del sector de la comunicación; blogs personales y 
páginas web de agencias de comunicación, entre otras fuentes. La finalidad de esta búsqueda ha sido el poder aportar un contexto sobre el mundo de los influencers y su aplicación a la comunicación de las marcas así como diferenciar sus tipologías.

Además, se ha realizado un análisis de contenido mediante el estudio de dos casos de comunicación de marca local en el que se contrataron influencers, y con el que se pretende determinar cómo se han llevado a cabo y qué tipo de resultados han obtenido aplicando este tipo de estrategias.

Finalmente, se aportan una serie de recomendaciones y pasos para aplicar de manera correcta y eficaz una estrategia de marca basada en la contratación de un influencer.

\section{CONTEXTUALIZACIÓN DEL TEMA}

Según Daniel Solana, CEO de la Agencia Interactiva Double You: «Los asuntos de las marcas suelen construir conversaciones forzadas que, por lo general, poco tienen que ver con el interés del público. Los asuntos de la gente, en cambio, fascinan a la gente. Es obvio, ¿no? Pues bien, la gente del marketing y la publicidad parece que no acabemos de entenderlo». En este fragmento, extraído de su libro del año 2010 Postpublicidad, Solana, uno de los grandes de la publicidad en España, ya parecía predecir que el futuro de la publicidad pasaría por la generación de contenido y por las figuras de los influenciadores.

\subsection{Diferencia entre influencer y microinfluencer}

Para seguir desarrollando el tema es importante conocer unos conceptos básicos, que se repetirán a lo largo de toda la exposición: ¿Qué es un microinfluencer? ¿Qué diferencia existe entre un influencer y un microinfluencer?

Todo el mundo sabe ya a estas alturas que los influencers son esas personas que, contando con cierta credibilidad sobre algún tema concreto, 
pueden llegar a convertirse en un prescriptor de marca gracias a su presencia e influencia en redes sociales.

Los microinfluencers no cuentan con las mismas cifras en cuanto a seguidores de los influencers, y son considerados usuarios «normales» ya que no tienen un estatus de celebridad y además suelen interactuar frecuentemente con sus seguidores de manera natural. Estos microinfluencers hablan e «influyen» en las decisiones de compra. En definitiva, gozan de una enorme credibilidad por parte de sus seguidores, con ratios de engagement muy elevados.

La mayoría de influencers ya son más que reconocibles por la gran mayoría de usuarios de redes sociales, por lo que cuando estos prescriben un producto o marca a través de su blog, o subiendo una foto a su perfil de redes sociales; esto se percibe como lo que es: publicidad, y pierde credibilidad ante el seguidor. Por su parte la utilización de los microinfluencers va ganando terreno. Las marcas desean ganar valor y ser más creíbles ante sus públicos objetivos. La clave de este tipo de influencers está en la posibilidad de segmentación en los temas como deporte, música o cocina creando pequeñas comunidades. $\mathrm{O}$ incluso por región o localidad, convirtiéndose en auténticos prescriptores de una ciudad o de actividades que se desarrollan en la misma. En cualquier caso, la clave es que sus seguidores lo son al cien por cien por sus contenidos.

Unos ejemplos de influencers locales serían el blog Madrid Diferente (madriddiferente.com), una completísima guía que recoge día a día las propuestas de ocio, cultura y gastronomía más apetecibles que tienen lugar en Madrid, y que en poco tiempo se han convertido en referentes totales a la hora de conocer las novedades o planificar el tiempo de ocio en la capital. Otro ejemplo de influencer local sería la mediática Cristina Calatrava (@ criscalatrava),enfermera de profesión, pero apasionada de la moda, que a través de su Blog y sus perfiles sociales ha sabido crear su propia «marca personal» y situarse entre uno de los perfiles de microinfluencers más demandado para campañas locales en Valencia. La entrada en su blog sobre «Cómo maquillarse de fallera» es una de las más vistas. 


\subsection{Contratación de microinfluencers}

Ya sabemos qué es un influencer, pero ¿de verdad es rentable la contratación de estos perfiles para promocionar una marca?

Los usuarios de redes sociales otorgan credibilidad a los perfiles que siguen, por lo que la notoriedad de esa marca puede incrementarse si se complementa con los contenidos que puede generar un microinfluencer, cuando este está bien escogido (experto en la materia de la que trata), y el público objetivo es, sobre todo juvenil, o femenino», afirma Raquel Herrera, profesora de Comunicación Digital Cultural en el postgrado en SEo y Social Media para Comunicadores de la UPF Barcelona School of Management.

Los objetivos que persiguen la mayoría de marcas que terminan contratando a un influencer son, generalmente, dos: visibilidad y naturalidad.

- Visibilidad que permite aparecer junto a un usuario que o bien es experto en la materia, o bien tiene muchos más seguidores que la propia marca. En el caso de la comunicación local y los microinfluencers, el objetivo prioritario es la posibilidad de aparecer con alguien que sabe de lo que habla porque así lo ha demostrado en su muro a través de diferentes y variados posts que lo acreditan, y que sus seguidores puedan asociarla a esa persona, de manera que, si esa persona aparece con nuestra marca o producto, nos transfiere parte de ese know how o conocimiento.

- Y naturalidad, porque si el tema está relacionado con la marca, los seguidores van a absorber ese contenido como algo propio del experto, por lo que la prescripción de ese producto está más reconocida.

En resumen, los influencers tienen un alcance masivo aunque mucho menos profundo debido a la falta de engagement con su audiencia; mientras que los microinfluencers impactan en menos personas, pero de manera más cercana y natural, lo que provoca mayor credibilidad y contundencia 
en el recuerdo. Esto provoca que en el mercado se empiece a producir una migración: las marcas empiezan a buscar influencers con audiencias más pequeñas, pero con unas tasas de engagement mucho más elevadas.

El ejemplo más relevante podría ser el de la industria de la moda, la cosmética y el lujo, que son los principales inversores en influencers para promocionar sus productos. Según el estudio de la web eMarketer, los influencers se llevan el 33,6 \% de cuota de mercado, los megainfluencers (más de 500.000 seguidores), el 9,3\% y los famosos (más de 1,5 millones de seguidores) el 11,3\%. El resto de del porcentaje va a parar a los microinfluencers, con el 45,8 \% de cuota de mercado. Además, existe otra razón que también recoge el análisis: a medida que los influencers se hacían más grandes, estos empezaban a vivir de ello, por lo que empezaron a profesionalizarse y a perder lo que en principio las marcas querían conseguir de ellos: naturalidad, frescura y conocimiento de un tema concreto.

Llevando esta teoría al negocio local, se puede identificar una tienda de ropa a través de un microinfluencer local que vista los productos y los muestre en su blog o redes sociales. $\mathrm{O}$ si el negocio es un restaurante, se puede abrir canal propio y empezar a producir contenido exclusivo, que además sea útil y entretenido para la audiencia potencial. O contratar a alguien que ya esté bien posicionado como blogger o microinfluencer foodie y sirva para darse a conocer en una región concreta.

Un caso más que evidente donde ya se han producido muchas microcampañas es el turismo rural. Según el Observatorio del Turismo Rural, proyecto liderado por Escapadarural.com, CETT-UB y Netquest, lo que más influye en la elección del destino son los blogs de viajes o los perfiles sociales relacionados con los viajes. E1 29,9 \% de los viajeros rurales indican que acuden a estas webs a informarse y decantarse por un lugar $\mathrm{u}$ otro, además obtienen información de la zona, qué se puede realizar, si se puede o no ir con niños, o simplemente consultar qué y donde comer lo típico de esa región. Este porcentaje se sitúa por encima de las recomendaciones de amigos o familiares $(27,5 \%)$, y de la publicidad tradicional en prensa, radio o TV $(5,4 \%)$. Por tanto, observamos un claro indicador que los hábitos de consumo turístico han cambiado. 


\subsection{La búsqueda de microinfluencers}

La búsqueda de microinfluencers no resulta nada fácil. Según la web postcron.com «lo importante es conseguir al/la influencer adecuado/a» y nos deja una serie de consejos a tener en cuenta a la hora de buscar un buen microinfluencer:

- Hacer un seguimiento durante un tiempo en sus redes sociales: investigar quién o quiénes publican contenido adecuado sobre el público objetivo de manera regular y con una estética cuidada y creíble.

- Para encontrarlos es muy importante el rastreo a través de hashtags. De esta manera daremos con un «nicho» adecuado a nuestros intereses.

- Google siempre nos ayudará a «investigar» en mayor profundidad sobre la idoneidad del perfil o incluso a buscar candidatos de cero. Debemos ser muy específicos en nuestra búsqueda y acotar bien las palabras utilizadas.

Desde postcron.com también insisten en que para la elección del más conveniente es indispensable tener en cuenta otros tantos factores:

- Que publique regularmente.

- Que tenga un buen engagement: Nos interesa que sus seguidores interactúen con sus contenidos. Nos interesa que etiqueten y que responsan las dudas o preguntas de sus seguidores. Toda interacción genera confianza.

- Evidentemente, que el tipo de contenido de esa persona vaya con nuestra marca o producto.

- Por último, es importante saber cómo vamos a pagar su colaboración: existen multitud de opciones, desde una remuneración monetaria hasta pagos en especies. 


\subsection{Cómo definir una campaña de microinfluencers para un negocio local}

Tenemos las claves para poder afinar en la contratación de microinfluencers, pero esto es solo una parte a la hora de poner en marcha una campaña. A continuación, y gracias al blog de Bego Romero, intentaremos definir una estrategia de social media para cualquier marca, integrando en ella una campaña de microinfluencers:

El primer paso es obvio: Analizar la competencia. Qué tipo de acciones realiza en social media, cómo comunica, con qué frecuencia, y si utiliza algún tipo de apoyo en influencers, etc.

El segundo paso también es de manual: Analizar qué se pretende hacer y qué objetivos se marcan (KPI). Objetivos hay casi infinitos, por lo que se debe tener muy claro qué es lo que interesa, y marcar uno o a lo sumo, dos objetivos siempre y cuando estén relacionados: por ejemplo, notoriedad en redes sociales y conseguir mayor número de seguidores. Este paso es crucial, ya que en base a lo que decidamos en él, enfocaremos la campaña de diferente modo.

El tercer paso es escoger la red social donde se va a hacer la campaña. Para ello no se escogerá la red social donde más bonitas se vean las fotos o los mensajes, sino que vamos a escoger la red social donde esté nuestro público. No es lo mismo una campaña dirigida a chicas de entre $15 \mathrm{y}$ 20 años, que una campaña dirigida a hombres de más de 50 años. Para ello, además, será importante estar al día en donde se mueve el público objetivo, y recordar que existen más canales de los ya conocidos Facebook, YouTube, Twitter e Instagram.

El cuarto paso es el de seleccionar a los influencers, que ya se ha visto a lo largo de este trabajo. Teniendo claro los pasos a seguir para encontrar los que más y mejor se adecuen a la marca o el producto, es más fácil poder conseguir mejores resultados.

Una vez se hayan definido los objetivos, a la competencia, la red o redes sociales más óptimas y a los influencers, es momento de lanzar la campaña. Llega el momento de la verdad, así que se deben comprobar 
cada uno de los pasos. Es importante que se acuerde con el influencer con el que se va a colaborar qué tipo de post y de colaboración se va a iniciar conjuntamente. Es más importante todavía que el influencer enseñe previamente qué va a publicar antes de hacerlo, para que haya acuerdo y no haya ninguna sorpresa. En este punto es clave que el mensaje que se va a dar no diste en tono y forma de los que habitual hace el influencer contratado. Si se quiere imponer un tono y estilo diferente al que sigue esta persona, el mensaje en el que aparecerá la marca será muy diferente a los que habitualmente realiza y, por tanto, se concebirá como un mensaje publicitario que no está integrado en su perfil de manera natural, por lo que pierde aquello más importante por lo que se contrata a estas personas: aproximar la marca a la experiencia y sabiduría que nos proporcionan estos perfiles. Por tanto, antes de realizar esta inversión, debemos estar muy seguros de dejar la marca en manos de alguien que en principio, la va a potenciar, y a la que para ello, necesariamente, tendremos que aproximar a su manera de decir y hacer las cosas.

Y una vez iniciada la campaña es muy «importante» que se controlen los comentarios, y que el influencer responda las dudas que puedan plantear sus seguidores. Si no tiene clara alguna respuesta deberá consultarlo con la marca siempre antes de publicarla. Por último, pero no menos importante, asignar un hashtag especial para esa campaña y realizar un seguimiento. El hashtag debe ser único para la campaña. Que contenga o no la marca es lo menos importante, aunque es cierto que, si se quieren evitar duplicidades y tener un hashtag único, es más fácil conseguirlo incluyéndola en él.

Una vez lanzada la campaña, es hora de monitorizarla. Hay multitud de herramientas, miles de ellas. Algunas muy útiles y otras no tanto, por lo que es importante que previamente se determine cómo se va a realizar esta monitorización. Lo importante es que se pueda monitorizar el hashtag y la URL (si existe) de campaña, ya que a través de ella sabremos cómo y de dónde viene el tráfico a la web principal.

A continuación, se analizan dos ejemplos reales de campañas con micro influencers. La idea es estudiar el motivo del inicio de cada uno de los 
ejemplos y en respuesta a qué problema lo hace; así como indagar en los objetivos marcados y la solución aplicada.

Se han seleccionado estos dos casos frente a otros, por ser campañas de un ámbito geográfico muy limitado, la primera; y por ser un infuencer atípico, la segunda.

\subsection{Análisis del caso de campaña de microinfluencers: My Bajo Aragón}

¿Qué es? El Bajo Aragón es una comarca de la provincia de Teruel, limítrofe con Tarragona, compuesta por veinte municipios y unas 30.000 personas.

El problema. Los habitantes de la comarca del Bajo Aragón, especialmente los jóvenes, cuando tienen que hacer compras, o bien piden online en webs como Amazon, El Corte Inglés, Zara... o se desplazan a centros comerciales de ciudades cercanas como Zaragoza. Todo esto hace que el comercio local no atraviese su mejor momento, y que la aspiración de los habitantes de esta comarca a nivel laboral no sea la de emprender y generar riqueza en la zona, sino la de irse a ciudades como Zaragoza, Barcelona o Madrid; o la de poder trabajar para la administración. Pero si nadie genera riqueza, ¿Cómo poder sostener los sueldos que paga la administración?

La oportunidad. Quienes realizan ya la mayoría de compras online son los llamados millenials, que controlan el mundo digital, buscan recomendaciones a través de perfiles de influencers a los que siguen y creen, les entretienen y divierten. Siguen a estos perfiles de todas las partes del mundo que marcan las tendencias y la manera de consumirlas.

La solución. Atraer a esos consumidores de la manera en la que ellos están acostumbrados a consumir: a través de las redes sociales y concretamente de perfiles sociales de influencers. Evidentemente, por un tema económico no se puede contar con perfiles de megainfluencers como el de las Kardashian o Cristiano Ronaldo, con millones de seguidores; pero tras analizar su entorno sí tienen a mano a diferentes personas de la comarca del Bajo Aragón, muy activas en redes sociales, que entienden 
que ese es el camino a seguir y trabajan además en poder conseguir mayor audiencia para sus perfiles, generando contenidos de calidad e interesantes. Además, descubrieron que la mayoría de seguidores con los que cuentan estos microinfluencers pertenecen a la comarca.

El objetivo. Juntar esos perfiles y crear un grupo de influencers para que compartan contenidos y experiencias que atraigan a sus seguidores de cara a conseguir objetivos como mejorar la notoriedad de los comercios de la comarca del Bajo Aragón, tener visibilidad en redes sociales gracias a la prescripción de estas «personalidades», crear contenidos adecuados a los públicos objetivos, aumentar el tráfico de las páginas webs de los comercios (aquellas que tengan), y sobre todo, hacer que los jóvenes que habitan la comarca, los millenials citados anteriormente, sientan orgullo de pertenencia a su tierra y tengan a los comercios del Bajo Aragón como una opción real de compra (figura 1).
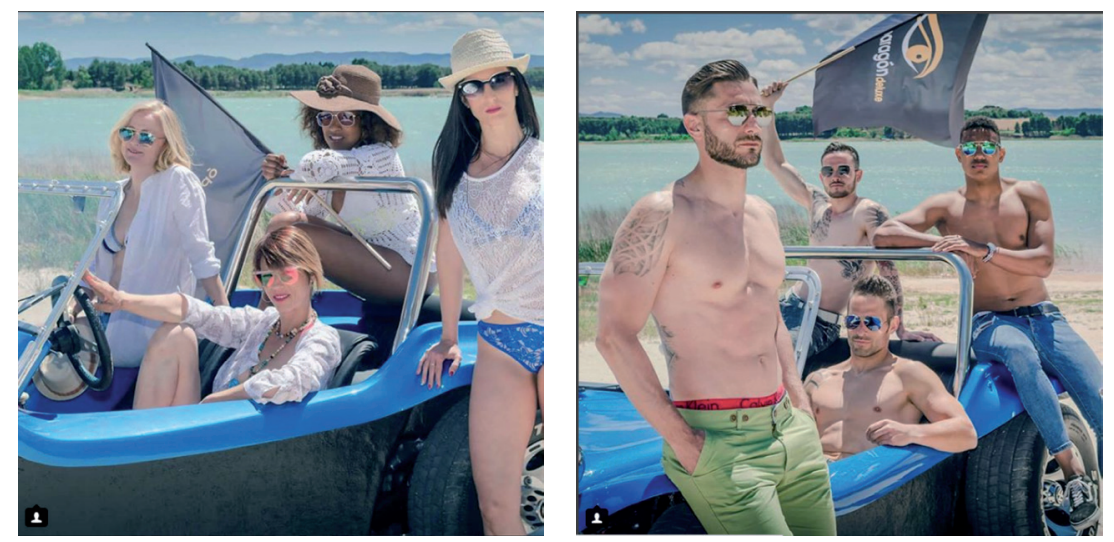

Figura 1. Campaña de verano 2018 para Ópticas Bajo Aragón, con algunos de los influencers locales utilizados en la Campaña \#MyBajoAragón

El resultado. No existe una recopilación de resultados de manera oficial, y los intentos de contactar con el presidente de la Asociación de Comerciantes del Bajo Aragón solicitando los resultados de campaña han sido infructuosos, sin embargo, no es difícil aventurarse a hacer un supuesto de alcance 
de las publicaciones realizadas. La media de los perfiles consultados (que han participado en la campaña de \#MyBajoAragón), en cuanto a seguidores es de unos 600 por cada uno de los perfiles. Estos 600 seguidores son, en su mayoría gente de su entorno: amigos, compañeros de trabajo, de clase, conocidos... es decir, la gran mayoría de ellos pertenecientes a un entorno cercano, y público objetivo de la Asociación de Comerciantes. Si cada post se publicaba en los perfiles del comercio, y en los de los influenciadores locales, las impresiones de cada uno de esos posts se han multiplicado por una mínima inversión. Y lo mejor, han llegado a público objetivo real, gente que no contemplaba los comercios locales como opción real de compra para determinados productos, como la moda.

\subsection{Ejemplo de campaña de microinfluencers: el perrito Pipper}

El siguiente caso analizado cuenta con un influencer muy peculiar: un perro. Pipper es un perrito de la raza parson russell terrier, que está recorriendo España en compañía de su dueño mostrando lugares dog

friendly. Cada vez son más los que planifican sus vacaciones o escapadas teniendo en cuenta a sus mascotas, y eso no pasó desapercibido para Pablo Muñoz, periodista y dueño de Pipper, que sabe que esos espacios dog friendly son un negocio en alza.

Pipper On Tour, que así se llama la iniciativa, está inspirado en modelos similares a los impulsados en países como Japón, Colombia o Perú, con un componente social, en el que se trata de eliminar clichés establecidos por el desconocimiento, y hacer entender que también se puede viajar con mascotas sin ocasionar molestias. Pero no se trata de hacerlo en un entorno cualquiera, se trata de hacerlo en España, que es el segundo país que más turistas recibe a año. Y se trata de hacerlo dando a conocer los principales destinos del país y los recursos turísticos que están abriendo sus puertas a quienes viajan acompañados de su perro.

Pipper cuenta ya con más de 40.000 seguidores (septiembre 2018), y utiliza su popularidad para promocionar el turismo de mascotas. Para difundir las actividades, monumentos que puede visitar, o los museos donde puede entrar, ha creado perfiles en redes sociales como Facebook, 
YouTube o Instagram, además cuenta con un blog donde se pueden consultar hoteles, bares y otros establecimientos $d o g$ friendly de todas las ciudades que visita.

El ejemplo de Pipper es el de utilizar un referente experto en la materia para un «nicho» de seguidores. En este caso, Pipper, a través de su dueño, no cuenta en primera persona aquellos lugares que visitar, donde descansar, comer... en todas las principales ciudades españolas. Y es que la iniciativa empezó en mayo de 2018 y tiene previsto visitar cincuenta capitales españolas;se prevé que el tour de Pipper termine en mayo de 2019. Un año donde Pablo y su mascota van a «enganchar» a miles de seguidores (creados desde cero) a los que les interese el tema del que son expertos, o simplemente, les diviertan a través de la generación de contenido.

Evidentemente, esta iniciativa no ha pasado desapercibida y Pipper cuenta ya con millones de impresiones en prensa digital, ha aparecido en los informativos de casi todas las cadenas, y cuenta ya con una comunidad de fans considerable (23.500 en Instagram, 14.000 en Facebook, y más de 1.000 suscriptores en su canal de YouTube), lo cual ha propiciado que cada vez sean más los que quieran contar con Pipper de una u otra manera.

A los patrocinadores «oficiales» con los que cuenta el parson russel terrier (Renfe para el transporte, Bayer para la salud del perrito, Dango Natura para su alimentación y Trixie para sus correas y accesorios); Pipper cuenta con el patrocinio de Castilla y León, que le ha nombrado «embajador para el turismo de mascotas», ya que en 2019 quiere posicionarse como «región turística para mascotas». Pero no todo queda aquí, ya que la página web www.pipperontour.es ya es un elemento participativo donde los propietarios de hoteles, restaurantes o actividades turísticas dog friendly pueden pedir a Pipper que les visite cuando vaya a su ciudad y de esta manera promocionar su negocio a través del influencer canino.

La importancia de esta acción está siendo tal, que Pipper es ya un habitual de la prensa local de los sitios que visita y ha aparecido en multitud de medios nacionales, e incluso internacionales, teniendo repercusión en algunos de los países de los que más turistas recibimos, como Reino Unido, Rusia, Italia, o los países nórdicos (figura 2). 

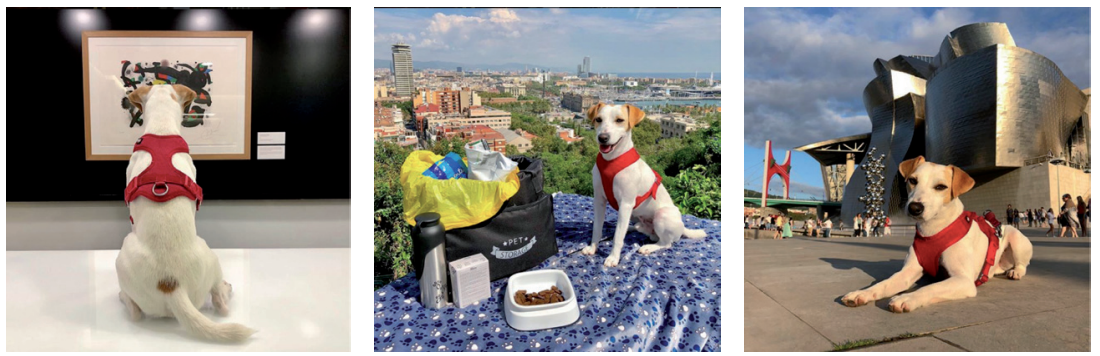

Figura 2. Pipper disfrutando de un cuadro de Miró en Barcelona, de un pícnic con una de sus marcas favoritas en Montjuïc, o posando frente al Guggenheim en Bilbao.

\section{CONCLUSIONES}

Este proyecto nace del interés de colaboración entre las marcas y aquellas personas que ejercen influencia a través de sus perfiles sociales, diferenciando ese tipo de influencia según su número de seguidores, y las marcas que pretenden incorporarlas en sus estrategias de comunicación. Estas estrategias de influencers están asentándose cada día más en la realización de estrategias digitales para muchas marcas por su relativo bajo coste y su eficacia. Este aumento de predisposición por parte de usuarios a seguir las recomendaciones de esos microinfluenciadores sigue creciendo, y se ha pretendido con este proyecto trasladar estas técnicas a la comunicación de ámbito local. Las conclusiones extraídas son las siguientes:

- Los microinfluencers crean y comparten contenido interesante para sus públicos, que llegan a identificarse con ellos.

- Los microinfluencers tienen su propia personalidad e ideas que entran en juego a la hora de crear y compartir información para una determinada marca. Esta manera propia de comunicar funciona entre su comunidad, por lo que lo inteligente es dejar que actúen con tu marca como lo harían ellos mismos. 
- Estos microinfluencers cuentan con una excelente reputación en redes, trabajada a diario, así como una excelente relación con sus seguidores.

- Son percibidos como personas honestas consigo mismas y no como meros portavoces, por lo que sus opiniones son muy valoradas entre su comunidad.

- Y lo mejor de todo, los microinfluencers cuentan con un público mayoritariamente homogéneo bien sea por estilo de vida, aficiones gustos o pertenencia a una zona geográfica concreta.

Todos estos puntos son algo que realmente interesa a cualquier marca.

Hoy en día, según el estudio de 2018 «Global Influencer Marketing: What Platforms to Use, Policies to Follow and the Paths to Purchase Around the World» de eMarketer, el $84 \%$ de los profesionales de la comunicación y el marketing recurren a campañas con influencers y el $50 \%$ de ellos las califican de «exitosas». Los profesionales valoran que son más útiles cuando el objetivo es aumentar la visibilidad y el valor de marca (93\%), fidelizar clientes (76\%) y crear oportunidades comerciales y apoyar las ventas $(75 \%)$.

El principal desafío se encuentra en encontrar al influencer ideal para la marca, seguido por el de captar la atención mediante tácticas de engagement adaptadas. En este documento se ha intentado dar con algunas de las claves en pro de facilitar esa búsqueda de «influencer ideal».

Para poner en marcha una campaña con influencers, se deben analizar una serie de variables relacionadas con nuestra marca, con la competencia, y la zona donde se desarrolla la actividad. Una vez analizadas todas esas variables concretaremos cuál es nuestro público objetivo y cómo podemos llegar a él, y a través de qué perfiles sociales, fijando una serie de objetivos que posteriormente mediremos. La elección de los perfiles de microinfluencer ideal no vendrá determinada por el número de seguidores que tiene, sino por la temática de sus contenidos y por el grado de engagement que genera. A partir de aquí se realiza el contacto y se negocia con el/los perfiles seleccionados. Una vez lanzada la campaña, 
deberemos medir los resultados ya que gracias a esta evaluación determinaremos en qué grado nos ha ayudado a cumplir nuestros objetivos, y qué podemos mantener o mejorar de cara a una posible futura nueva colaboración.

Como conclusión final, citar las grandes ventajas que se extraen de este trabajo cuando se trabaja con influencers:

1) Contribuye al posicionamiento SEO: los seguidores se suelen hacer eco de lo que hablan sus referentes. Por tanto, si los influencers generan contenido sobre una marca, probablemente sus seguidores también lo harán, y así, irá aumentando la cantidad de contenido sobre esa marca generado por usuarios.

2) Mejora la reputación de la marca: los buenos influencers actúan como una garantía de calidad, ya que su público confía plenamente en su opinión.

3) Publicidad más efectiva: al ser un contenido de interés para su audiencia, en la mayoría de casos no es ni percibida como publicidad, por tanto, es más efectiva.

4) Genera reacciones y conversación en torno a la marca, incrementando las menciones en las redes sociales, sitios web, blogs, etc.

5) Incrementa las visitas web: si se utilizan enlaces, es posible llevar una mayor cantidad de visitas hacia la web y por tanto, aumentar las conversiones.

\section{BIBLIOGRAFÍA}

Blog 40defiebre.com, editado por Socialmood.

Blog Businessgo. 2018. Microinfluencers: pequeñas Grandes influencias. http://cort.as/-E6N1

Bustamante, Fátima. 2018. «Los influencers reinventan el mundo de la Publicidad». La Vanguardia. http://cort.as/-E6Nq

eMarketer. 2015. Growth of Time Spent on Mobile Devices Slows. http:// cort.as/-E6Nv 
—. 2018. Global Influencer Marketing: What Platforms to Use, Policies to Follow and the Paths to Purchase Around the World. http://cort. as/-E6Nw

Esteban, Isabel. 2017. «Los influencers locales marcan tendencia». La Comarca. http://cort.as/-E6Ny

Gamero, M. 2015. «Los brand ambassadors, un paso más en el marketing de influencia». IpMark: Información de Publicidad y Marketing, 812.

Hernández, R. 2016. «Atrevia». Blog Atrevia. http://cort.as/-E6O-

Herrera, Raquel. 2016. Comunicación Digital Cultural en el Postgrado en SEO y Social Media para Comunicadores. Barcelona: Universitat Pompeu Fabra Barcelona School of Management.

IAB. 2018. Estudio anual de redes sociales.

-. 2017. Estudio anual de redes sociales.

-. 2017. TOP tendencias 2017.

Influencity. 2018. «¿Qué son los microinfluencers exactamente?» Blog Influencity. http://cort.as/-E6O1

Kasitoko. 2018. «Diferencia entre infuencer y microinfluencer». Blog Kasitoko.com. http://cort.as/-E6OA

Lorente, M. 2014. «Influencers». Magazine Tecnología, 26.

Matas, Rosa 2018. «Las pymes se fijan en los microinfluencers». La Vanguardia. http://cort.as/-E6OD

Moreno, M. 2014. «Un $73 \%$ de los profesionales de la comunicación se relaciona con Influencers». PuroMarketing. http://cort.as/-E6OG Muñoz Gabilondo, Pablo. 2018. www.pipperontour.com

Neurads. 2015. «Estudio sobre branded content». ContentScope. Madrid: Grupo Consultores.

Pérez García, Óscar. My bajo Aragón [canal de YouTube de la Asociación local de influencers]. http://cort.as/-E6OL

Puromarketing.com. 2018. Vivir de las redes sociales: Objetivo para el $50 \%$ de los microinfluencers. http://cort.as/-E6OP

Rodríguez, L. 2015. «Los influencers: una ¿nueva? tendencia publicitaria». IpMark: Información de Publicidad y Marketing, 812: 54.

Romero, Begoña. 2017. El Blog de Bego Romero. www.blogbegoromero. com 
Skaf, Eugenia. 2018. «iPor qué deberías utilizar un microinfluencer para impulsar tu negocio local?» Blog Postcron. http://cort.as/-E6OX

Socialmediapymes. 2018. «¿Cómo diferenciar influencers, microinfluencers y celebrities?» En: Blog Socialmediapymes.com. http://cort.as/-E6OA

Solana, D. 2010. Postpublicidad: reflexiones sobre una nueva cultura publicitaria.

TV3. 2017. «Els Youtubers, els nous ídols». En: 30 minuts.

Villaveces, S. 2016. El arte de elegir al influenciador ideal. http://cort. as/-E6Oe

Villodres, María L. 2018. «El fenómeno del influencer local: blogueras que arrasan en su ciudad». Divinity.es. http://cort.as/-E6On

Webretail 2018. «La Era de los microinfluencers». Blog Web Retail. http://cort.as/-E6P_ 


\section{DISEÑO Y EVALUACIÓN DE UN MODELO \\ DE MARKETING Y COMUNICACIÓN \\ MÓVILES PARA LA CAPTACIÓN \\ Y FIDELIZACIÓN DE ESTUDIANTES \\ EN LA UNIVERSIDAD CEU CARDENAL \\ HERRERA}

José Antonio Martínez Gómez

Universidad CEU Cardenal Herrera

\section{Resumen}

La sociedad del aprendizaje ha hecho surgir una industria educativa global impulsada por el mercado, por la creciente competencia local e internacional y por la aparición de tecnologías móviles disruptivas. En este contexto, la comunicación digital entre la universidad y su audiencia debe ser reticular e interactiva, pues los receptores son también creadores de contenidos. El funnel tradicional ha sido sustituido por micromomentos, claves en el proceso de toma de decisiones de los estudiantes potenciales y en el camino hacia la lealtad a la marca de todos sus públicos objetivos.

Se propone un modelo de marketing y comunicación móvil para captación y fidelización de estudiantes para la Universidad ceu Cardenal Herrera. El modelo se ha obtenido mediante análisis de la literatura científica y especializada, y de publicaciones periódicas de firmas y empresas referentes en el sector de la educación superior. La estrategia consiste en dos fases. Por una parte, desarrollo y modernización de medios -sitio web, intranet y red de blogs optimizados para móviles- e implantación de un CRM y de una plataforma de automatización de marketing. Por otra, la estrategia digital, dividida en acciones estáticas sobre medios propios -SEO, contenidos y social media- y en acciones dinámicas de campaña-social ads, SEM, display, mailing y marketing de proximidad.

Los resultados de la implantación, obtenidos mediante herramientas de analítica digital, demuestran el aumento del tráfico móvil. Mediante un focus group se ha observado que los estudiantes, a través de sus móviles, consumen contenido de interés general en el sitio web corporativo y contenido personalizado en la intranet. Los blogs se han convertido en los medios de expresión preferidos por la comunidad universitaria y el social es el canal de difusión más eficaz. 
Adicionalmente, el uso de acciones dinámicas de campaña amplifica el alcance y aumenta las tasas de participación. Sin embargo, el SEO sigue siendo el canal más relevante de tráfico global. Finalmente, el CRM y la automatización de marketing han multiplicado la eficiencia de la gestión de la relación con los estudiantes.

Palabras clave: universidad privada; marketing móvil; captación de estudiantes; fidelización de estudiantes; desarrollo mobile-first; estrategia digital en medios móviles.

\section{INTRODUCCIÓN}

$\mathrm{E}$

N UNA INDUSTRIA EDUCATIVA GLOBAL IMPULSADA por el mercado, las nuevas generaciones de estudiantes universitarios se caracterizan por haber adquirido los principios de la ética hacker de Himanen (2002). Estos jóvenes, pertenecientes a la llamada Generación Z, destacan por su espíritu emprendedor, por su pragmatismo, por su conciencia colectiva, por asumir con naturalidad la movilidad geográfica y por anteponer su desarrollo profesional y su vida personal a su estabilidad financiera. Han desarrollado su talento en un contexto de crisis y han aprendido que la pasión es la fuerza motriz para lograr sus objetivos.

Además, son nativos digitales. Los medios de comunicación digital constituyen el principal medio de interacción con su entorno (Scolari 2008), especialmente los basados en imágenes y vídeo. Por otra parte, las fuentes de conocimiento ya no están centralizadas, sino que son fruto de una convergencia - entre las industrias mediáticas y la cultura participativa- en la que juega un papel fundamental la economía afectiva, es decir, las bases emocionales de las decisiones tomadas por los consumidores (Jenkins 2006).

Así pues, la antigua comunicación jerárquica y unidireccional ha dado paso a una nueva, reticular e interactiva, en la que los receptores son también creadores de contenidos. Estos usuarios se han convertido en medios comunicantes en una sociedad red de cooperación horizontal 
(Castells 2009) que, gracias a la aparición de las tecnologías móviles disruptivas, pueden participar en cualquier momento y lugar.

En consecuencia, el embudo de conversión se combina constantemente con los micromomentos, presentados en un estudio de Google publicado por L. Adams, E. Burkholder y K. Hamilton (2015). Se trata de puntos críticos de contacto en la toma de decisiones de los consumidores. Por ejemplo: buscar información en el móvil es una acción realizada por el $65 \%$ de la muestra tomada, el uso del móvil para la búsqueda de lugares cercanos se duplica respecto al año anterior, más del $90 \%$ de los usuarios usan el móvil para aprender a hacer algo en ese momento y más del $80 \%$ lo consultan mientras están en una tienda para decidir su compra.

Estableciendo paralelismos con el caso de estudio, un usuario puede usar el móvil para buscar información sobre un tema de interés y encontrarlo en un artículo del blog de una universidad presente en las primeras posiciones de Google. A través de ese artículo, mediante un enlace, puede aterrizar en la página de una titulación universitaria afín al contenido. En cualquier otro momento y lugar, gracias a su smartphone, podrá realizar el proceso de admisión online y, a lo largo de su experiencia universitaria, podrá solventar necesidades o solucionar problemas a través de las plataformas digitales de la universidad, construyendo así un camino hacia su lealtad a la marca.

De acuerdo con esto, Kuzma y Wright (2013) demostraron la efectividad del uso de las redes sociales como herramienta de captación de estudiantes, pero su uso ha dejado de ser opcional. Actualmente, las instituciones educativas están obligadas a escuchar y a monitorizar las redes sociales, propias y ajenas, así como a ofrecer servicio a su comunidad a través de estos medios para conocer el mensaje final que llega al receptor.

Y es que las herramientas de e-marketing se han vuelto indispensables para el desarrollo de estrategias de comunicación segmentada entre las instituciones educativas y unos consumidores que usan, cada vez más, los medios online como una extensión de sus cuerpos y mentes (Kerckhove y Dewdney 1999). Las citadas redes sociales, los sitios web 
corporativos, los microsites, los blogs o las aplicaciones móviles ayudan a construir la imagen de marca de la universidad y a mejorar la percepción de ésta entre sus públicos objetivos (Štefko, Fedorko y Bačík 2015).

Entre las herramientas de e-marketing más innovadoras, se encuentran las herramientas de marketing móvil. Según la Mobile Marketing Association (2009), el marketing móvil es un conjunto de prácticas que permite a las organizaciones comunicarse y relacionarse con su audiencia de una manera interactiva y relevante a través de cualquier dispositivo o red móvil. En este sentido, Hayes \& Walker (2012) describen cómo varias universidades norteamericanas -como Stanford o Virginia University- fueron pioneras en detectar cambios en el comportamiento de los estudiantes a raíz de la aparición de las tecnologías móviles, asumiendo así la necesidad de incorporar herramientas de marketing móvil a su estrategia de comunicación multicanal.

Este hecho, unido a la escasez de referencias en la literatura científica, invita a recurrir a monografías sobre tendencias de marketing móvil en el sector de la educación superior norteamericano, así como a publicaciones en blogs de agencias de medios y en prensa sobre casos de estudio o acciones pioneras de marketing universitario. En base a la información recopilada, complementada con literatura especializada, se ha planteado un modelo de uso de las herramientas de comunicación y marketing multicanal para su implantación en la Universidad ceu Cardenal Herrera.

El modelo consta de dos fases. La primera consiste en el desarrollo y modernización de los medios propios, que se enumeran a continuación:

\subsection{Sitio web corporativo y blogs optimizados para móviles}

Según Dushinski (2012), un sitio web corporativo es el eje principal mediante el cual los usuarios se conectan con una organización a través de internet. Además, actúa como página de destino del resto de herramientas de marketing móvil, por lo que adaptar el diseño del sitio web al tamaño de pantalla del dispositivo es fundamental (Rowles 2013). Es más, hay que asegurarse de ofrecer la mejor usabilidad y experiencia de usuario posible cuando se accede desde múltiples dispositivos (Krum 
2010). Para conseguirlo, un aspecto fundamental es optimizar la velocidad de carga de la plataforma en dispositivos móviles para evitar que los usuarios la abandonen (An 2018).

Las dos técnicas más extendidas actualmente son las siguientes:

- Diseño web responsivo. Marcotte (2011) ideó un método para optimizar una única web a dispositivos de distintos tamaños mediante un diseño flexible y adaptable a las distintas resoluciones de pantalla, llamándolo web responsive design.

- Mobile First. Wrobleski (2011) expuso que cualquier página web de producto debería ser diseñada pensando primero y principalmente en dispositivos móviles. La afirmación se basa en las expectativas de crecimiento del tráfico de datos móviles frente al tráfico de escritorio. Cuatro años más tarde, Google lanzaría la actualización de su algoritmo para priorizar los sitios web mobile friendly (Makino y Phan 2015).

La Universidad de Notre Dame fue una de las instituciones pioneras en pasar de un diseño ligeramente adaptativo a responsivo, dando preferencia a las resoluciones móviles (Joly 2012). En poco tiempo, las universidades de West Virginia, California-San Diego y North Carolina State también decidieron adoptar una estrategia mobile-first para mejorar la captación y retención de estudiantes (Shein 2015). Según Runyon (2018), director técnico del departamento de marketing en la universidad de Notre Dame, actualmente más de trescientas universidades norteamericanas tienen su sitio web optimizado para su visualización en dispositivos móviles.

Otras dos herramientas de marketing móvil aplicadas a sitios web y usadas por las instituciones de educación superior en Estados Unidos son las siguientes:

- Landing pages de campaña. Se trata de microsites orientados a dispositivos móviles para ser accedidos a través de otras herramientas de marketing, como los anuncios en buscadores (Becker y Arnold 2010, Krum 2010). Cada vez más universidades diseñan 
microsites específicos para distintas fases del proceso de captación de estudiantes (Lawlor 2017).

- Páginas Amp. Se trata de una biblioteca de código abierto que permite crear páginas web más sencillas y de carga casi instantánea (Google 2016). Están pensadas para ofrecer una alternativa más ligera a la versión web normal cuando se reciben visitas desde dispositivos móviles y conexiones lentas. En la universidad John Carroll de Ohio comenzaron a usar esta tecnología, en 2016, en sus contenidos bajo la plataforma WordPress (Joly 2016).

\subsection{Aplicaciones móviles}

No debe confundirse con los sitios web móviles. Las aplicaciones móviles son programas que se pueden descargar en un smartphone o tablet y que pueden usarse como una herramienta suplementaria para comunicar, entretener, generar engagement o vender productos a los usuarios. Es fundamental que las aplicaciones móviles ofrezcan un valor añadido o utilidad que supla las limitaciones del sitio web optimizado para móviles (Hopkins y Turner 2012).

Por ejemplo, hay universidades que apuestan por una única aplicación compuesta por diversos módulos, dirigiéndose así a diversos públicos objetivos (Modo Labs 2015). Otras prefieren desarrollar aplicaciones específicas para cada target, o incluso para la toma de decisiones en fases tempranas del funnel de conversión para captación. Es el caso de la Universidad de Kentucky, que desarrolló una para ayudar a los estudiantes de secundaria a elegir su especialidad (Gilliland 2017).

\subsection{Mobile Customer Relationship Management (m-CRM) y plataformas de automatización de marketing}

Diego (2006) define CRM como una estrategia de marketing focalizada en la gestión de las relaciones con cada cliente de forma unitaria, recogiendo sus datos mediante los diferentes canales de captación. Los datos 
se integran en todos los sistemas de información para ser accedidos desde distintas aplicaciones. Se fundamenta en el conocimiento de la persona mediante la explotación y análisis de sus datos para evaluar el nivel de captación y/o fidelización, estableciendo relaciones y patrones de comportamiento entre productos/servicios y clientes de forma personalizada.

También destaca el concepto de e-CRM, basado en la interacción con los usuarios mediante los soportes web, en la obtención de datos en base a su comportamiento y en la personalización del contenido a mostrar según sus preferencias. Además, prevé la llegada de las tecnologías móviles como futuro factor diferencial en la optimización del valor de las relaciones con el cliente. Hoy, gracias al m-CRM y a las plataformas de automatización de marketing, se puede capturar una amplia gama de datos de los usuarios y hacerles llegar mensajes multicanal.

Debido a la abundancia de los métodos de inscripción y de interacción con los estudiantes, las universidades norteamericanas confían, cada vez más, en las herramientas de gestión de las relaciones con ellos y en su automatización para el proceso de matrícula, así como para su avance a lo largo de la etapa universitaria. Las herramientas de automatización de marketing integran correo electrónico, marketing de contenidos y de redes sociales, páginas de aterrizaje y analítica integral con el fin de realizar las siguientes funciones: la definición, segmentación, programación y seguimiento de campañas; la construcción de flujos de trabajo para reducir tareas repetitivas; la gestión del correo electrónico, sms y campañas sociales a través de la evaluación del eetorno de la inversión (ROI); el desarrollo e integración de los call-to-action, formularios y landing pages para la generación de leads; la puntuación de la calidad de los leads y su prioridad de seguimiento; y la obtención de analíticas de campaña para atribuir el engagement y las inscripciones al canal correspondiente (Hanover Research 2015).

Tras la fase de desarrollo y modernización de medios, comienza la puesta en marcha de la estrategia digital. Se divide en dos partes, las acciones estáticas de marketing sobre los medios desarrollados y las acciones de marketing en campaña. Se describen en primer lugar las acciones estáticas sobre medios propios. 


\subsection{Técnicas de optimización de búsquedas orgánicas (SEO) en móviles}

En el ámbito del marketing en motores de búsqueda, el SEO ayuda a mejorar el posicionamiento de un sitio web en buscadores consultados desde dispositivos móviles (Krum 2010). De hecho, según Enge, Spencer y Stricchiola (2015), el mobile sEo se ha convertido en un elemento vital en la estrategia de marketing de búsquedas. Un algoritmo de Google, lanzado en 2015, determina si un sitio está o no optimizado para móviles e incorpora esta información en un ranking de resultados de búsqueda que en estos dispositivos es totalmente vertical. En este contexto, resulta crítico aparecer lo más alto posible en la lista de resultados para ser tenido en cuenta por los usuarios (Dushinski 2012, Rowles 2013). Para ello, las universidades norteamericanas utilizan en la actualidad las siguientes herramientas:

Fragmentos destacados. Los fragmentos destacados son resultados de búsqueda que aparecen en la parte superior de los resultados orgánicos de Google, debajo de los anuncios, en un recuadro. Los fragmentos destacados aparecen para responder la pregunta de un usuario de inmediato. Aportan, por tanto, una exposición de marca adicional muy potente en los resultados de búsqueda (Smarty 2017). Las universidades norteamericanas están haciendo uso de los fragmentos destacados para responder a preguntas relativas a ofertas académicas, consejos para elegir un buen programa académico o para conseguir ser un buen profesional en un área académica ofertada por la universidad (Cooper 2017).

Optimización de búsquedas por voz. Los dispositivos móviles han condicionado la forma en la que los usuarios realizan las búsquedas. En cualquier momento, en cualquier lugar, y de escribir en los buscadores a hablar con ellos. Según Lawson (2017), un $20 \%$ de las búsquedas en Google App ya se realizan por voz. Este tipo de búsquedas está estrechamente relacionado con las búsquedas de larga cola, en las que el usuario realiza preguntas relativamente largas, de alrededor de 29 palabras (Dean 2018). La página de FAQ de la Universidad de Nottingham o diversos posts del blog de la MIT School of Engineering son ejemplos de optimización para búsquedas por voz (Higher Education Marketing 2016). 


\subsection{Marketing de contenidos y redes sociales móviles}

Uno de los autores del concepto web 2.0, O'Reilly (2005), defiende que una empresa moderna debe aspirar a tener las mejores y más amigables bases de datos para que sus usuarios las utilicen, usando la red como plataforma. Con las herramientas adecuadas, es viable plantear una estrategia de marketing centrada en crear y distribuir contenido relevante, oportuno y coherente para captar y retener a sus públicos objetivos y, finalmente, generar acciones rentables de los clientes.

Para ello, en primer lugar, es esencial elaborar contenido de valor segmentado por los intereses de cada target. Posteriormente, es necesario un contenedor en el que plasmar ese contenido -un post, una infografía, un vídeo, etc.- y, finalmente, es necesario un canal de difusión. En este sentido, los canales más usados actualmente, con la masificación del uso de dispositivos móviles, siguen siendo las redes sociales. El acceso a las RR. SS. desde el smartphone permite un modelo de interacción basado en lo inmediato, de picoteo, presente y accesible en todo momento, donde triunfa el material audiovisual y donde las redes sociales pasan a entenderse como una herramienta para crear relaciones entre empresas y usuarios.

Existen diversos estudios que demuestran la efectividad del uso de las redes sociales en las universidades para comunicarse con los estudiantes y generar engagement (Ratliff 2011). De hecho, las principales universidades norteamericanas - como la Universidad de Cambridgeinvierten en equipos de comunicación digital expertos en el uso y adecuación de cada red social a sus públicos objetivos (Stoller 2017). También cabe destacar el auge de las redes sociales nativas móviles entre los estudiantes y el buen uso que diversas universidades estadounidenses - como la Universidad Estatal de Colorado o el Darmouth College- hacen de sus cuentas de Instagram (Kolowich 2017) y de Snapchat, esta última muy útil como herramienta de mensajería instantánea para universidades como la University of Houston (Harley 2014).

A continuación, se presenta la segunda parte de la estrategia digital, compuesta por las acciones dinámicas de campaña. 


\subsection{Publicidad en buscadores móviles}

Según Krum (2010), el marketing en motores de búsqueda incluye también la publicidad de pago en buscadores a coste por clic (CPC). Mediante esta técnica, los buscadores muestran anuncios de búsqueda pagados en las primeras posiciones del ranking, y su visibilidad en dispositivos móviles gana relevancia debido al reducido tamaño de la pantalla. Se trata, por tanto, de una de las herramientas más efectivas de marketing en motores de búsqueda en móviles. CPC es un sistema basado en subastas. Cuanto más se esté dispuesto a pagar por clic, más visitas obtendrá un anuncio. Con los anuncios de búsqueda por CPC, se puede conseguir instantáneamente el número uno en el ranking de búsqueda si se está dispuesto a ofertar más dinero por clic que la competencia (Rowles 2013). La inversión en CPC por parte de las principales universidades norteamericanas es considerable en Google y creciente también en el buscador Bing de Microsoft (Higher Education Marketing 2017).

\subsection{Formatos publicitarios en medios móviles}

Además de los tradicionales anuncios de display, existen diversos tipos de formatos más sofisticados que pueden adecuarse a dispositivos móviles, como el rich media o el vídeo adaptado a móvil. La publicidad móvil puede ser mostrada en sitios web móviles o aplicaciones, así como durante descargas, reproducciones de vídeo o visualización de correos electrónicos en estos dispositivos (Krum 2010). Las grandes ventajas del uso de formatos publicitarios móviles son, en primer lugar, una capacidad de segmentación del target muy preciso, basado en aspectos demográficos, de localización, tipo de dispositivo, sistema operativo, proveedor de red móvil o categorías de contenido dentro de una web o aplicación (Dushinski 2012). En segundo lugar, el rendimiento de las acciones publicitarias se puede medir y optimizar en tiempo real para mejorar el RoI. Finalmente, es una herramienta efectiva para redirigir a los usuarios, mediante call-to-actions, a páginas de aterrizaje de campaña, realizar descargas automáticas de aplicaciones o a iniciar una llamada de teléfono. 


\subsection{Publicaciones promocionadas en redes sociales móviles}

Los profesionales del marketing utilizan cada vez más la publicidad pagada en redes sociales como una herramienta integrada en las comunicaciones de marketing multicanal. Es cierto que existe un problema a la hora de medir el RoI, pero existe la oportunidad de proporcionarlo usando las métricas correctas (Nielsen 2013). Las principales redes sociales ofrecen opciones de publicidad, pero no todas se adecúan a cada target. Generalmente, las que mejor funcionan orgánicamente son la mejor solución para la creación de campañas publicitaras (Newberry 2018). Según un informe de TrackMaven (2017), en el ámbito de la educación superior estadounidense, Instagram es la red social que mayor tasa de engagement genera sobre sus perseguidores pese a tener uno de los menores índices de audiencia.

\subsection{Email marketing móvil}

Ruffalo Noel Levitz (2017) subraya que el correo electrónico es uno de los canales de comunicación más efectivos. Se trata de una poderosa herramienta para enviar mensajes directos y personalizados, así como para iniciar y mantener relaciones con el cliente (Chaffey \& Smith 2013). Dushinski (2012) enfatiza además que el envío de correos a través de dispositivos móviles ha mejorado la efectividad del email marketing, pues los usuarios reciben notificaciones en su móvil en cualquier momento y lugar. Es fundamental optimizar las campañas de correo electrónico con un diseño responsivo y enfocado principalmente para móviles, y mediante el uso de plataformas de automatización de marketing.

\subsection{Marketing de proximidad}

Existen diversas técnicas para interactuar con el usuario, en espacios cerrados, en función de su proximidad al lugar en el que se desea realizar una comunicación. Una de las tecnologías emergentes en este campo son los BLE beacons. Se trata de pequeñas computadoras que emiten señales 
bluetooth para ser captadas por otros dispositivos móviles que se encuentren en un rango cercano (Newman 2014). El dispositivo móvil podrá identificar varias balizas y calcular la distancia relativa a cada una, obteniendo así un reconocimiento de ubicación. Varias universidades norteamericanas - como la Universidad de Oklahoma- hacen uso de esta tecnología para enviar notificaciones a los móviles de los estudiantes cuando entran en la facultad y así, por ejemplo, ayudar a los usuarios a encontrar un aula concreta dentro de su campus (Hamblen 2015). Para ello, es necesario que el usuario se haya descargado previamente la aplicación móvil desarrollada por la universidad para este fin.

\section{METODOLOGÍA}

Para llevar a cabo la investigación, en primer lugar, se ha implantado el modelo, recién descrito de plataforma de marketing y comunicación móviles en la Universidad CEU Cardenal Herrera. Posteriormente, se han usado herramientas de evaluación y analítica digital para comprobar la optimización en dispositivos móviles de las plataformas desarrolladas, así como para evaluar las métricas obtenidas mediante la aplicación de las técnicas de marketing móvil en buscadores, redes sociales y otros medios digitales susceptibles de ser accedidos desde dispositivos móviles.

Además, se ha realizado una dinámica de grupo con diez estudiantes de grado de la universidad para conocer su percepción sobre la idoneidad del uso de las herramientas de marketing y comunicación móvil para captación y fidelización.

\subsection{Reclutamiento de estudiantes para el focus group}

Los criterios de inclusión se han ajustado al siguiente perfil: estudiantes de $1 .^{\circ}$ de grado de la Universidad CEU Cardenal Herrera, perteneciendo cada uno a una titulación diferente. Así, por una parte, los alumnos mantienen reciente la experiencia de su proceso de captación y, al provenir de grados distintos, aumenta la probabilidad de ser desconocidos entre 
sí, lo que permite disminuir la cohibición y aportar así una mayor riqueza al debate.

\subsection{Moderación del focus group}

La dinámica de grupo se celebró en mayo de 2018 bajo un clima abierto y de libre discusión en el que el moderador fue introduciendo los siguientes temas para conocer la experiencia y la opinión de los estudiantes.

En primer lugar, conocimiento y opinión sobre la adecuación de las plataformas de comunicación de la universidad, dispositivo a través del cual las consumieron, y su influencia en la decisión de solicitar admisión en la universidad.

En segundo lugar, conocimiento y opinión actual de los canales digitales de comunicación ofrecidos por la universidad, dispositivo a través del cual los consumen y opinión sobre la adecuación de su uso por parte de la universidad.

\section{OBJETIVOS}

El objetivo principal de la investigación es aportar un modelo de plataforma de comunicaciones y marketing móviles para su implementación en la Universidad CEU Cardenal Herrera. Posteriormente, se pretende evaluar la adecuación de la plataforma, los canales y la estrategia de comunicación en base a resultados analíticos y también según la perspectiva de los estudiantes de grado. En este último caso, se busca conocer cómo actúan los estudiantes a la hora de buscar información para la toma de decisiones tanto en la elección de su universidad como durante su estancia en el campus.

\section{RESULTADOS}

Las estadísticas de visitas al ecosistema web, obtenidas de un informe de Google Data Studio, indican un aumento claro del porcentaje de 
sesiones iniciadas desde un dispositivo móvil entre el curso académico 2015/16 y el 1017/18. A continuación, se desglosan las principales acciones realizadas por el equipo de marketing y los resultados obtenidos en el intento de seguir facilitando la comunicación móvil entre la universidad y sus públicos objetivos (figura 1).
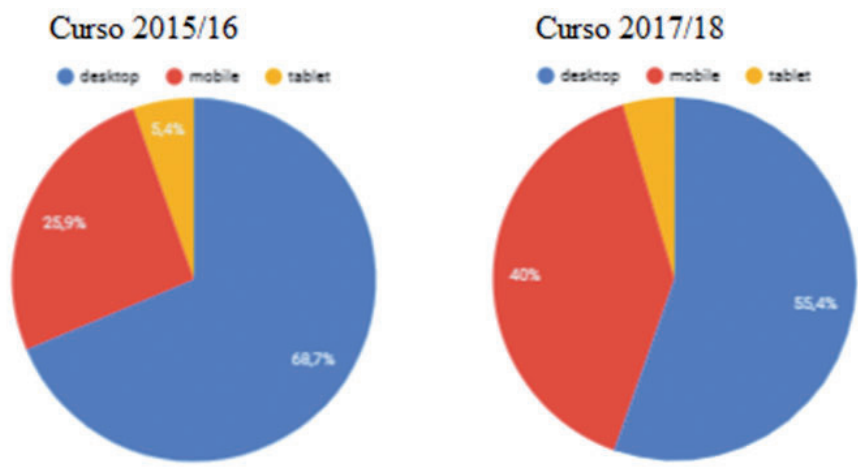

Figura 1. Dispositivo desde el que acceden a la web de la universidad Fuente: Google Data Studio

En primer lugar, se ha realizado el desarrollo de un nuevo sitio web corporativo responsivo y mobile-first, así como la modernización de la red de blogs de titulaciones y servicios de la universidad, también con el objetivo de priorizar su visualización desde dispositivos móviles para la difusión del contenido a través de las redes sociales.

Como se puede observar en la figura 2, obtenido de Google Search Console, la mayoría de las páginas del sitio se consideran válidas. Las 52 páginas fallidas son páginas migradas desde el antiguo sitio web, pendientes de rediseñar.

Por otra parte, en el Estudio Anual de Redes Sociales de IAB Spain se observa la consolidación de Instagram como red social preferida para la generación $\mathrm{Z}$ en España, en contraste con el estancamiento de la otra red social nativa móvil, Snapchat (Acebes, Mozas, Montanera y Julià 2018). Por esta razón, se ha apostado por la creación del perfil institucional de 
Instagram para generar mayor engagement entre los nuevos estudiantes universitarios.

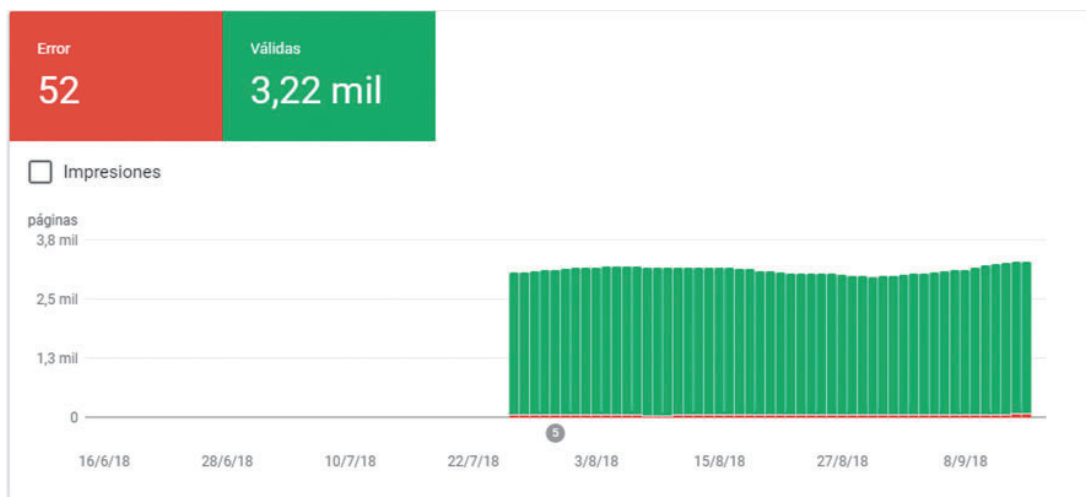

Figura 2. Página del sitio web mobile-friendly Fuente: Google Data Console

Posteriormente, se han desarrollado páginas de aterrizaje externas al sitio web corporativo para la realización de diversas campañas online en buscadores, en redes sociales o en otros soportes digitales. Estas páginas están provistas de un sencillo formulario de contacto -nombre, apellidos, dirección de correo y titulación de interés. Estos datos se almacenarán en un CRM, también implantado recientemente, generando así una ficha con el perfil de un estudiante potencial, que se irá ampliando en la medida en que la relación entre la universidad y el estudiante avance.

El objetivo es generar una base de datos del target para disponer de la información necesaria a la hora de establecer y mantener relaciones duraderas con ellos, desde la fase inicial del funnel de captación hasta el final de su estancia en la universidad. Una vez implantado el CRM, se ha trabajado en el desarrollo de una plataforma de automatización de marketing para diseñar plantillas mobile-first y generar flujos de trabajo que permitan automatizar acciones de email marketing, invitaciones a eventos, encuestas y formularios personalizados. 


\subsection{Estrategia digital. Acciones estáticas realizadas sobre las plataformas descritas en el modelo}

Las primeras acciones estratégicas están relacionadas con el SEO que, desde 2015, forma parte de la estrategia digital para mejorar los resultados de búsqueda de las páginas de producto del sitio web. Se ha trabajado el SEO on page, el linkbuilding, y más recientemente, la selección de palabras clave. Su importancia queda justificada por el gráfico de canales de entrada de tráfico móvil al ecosistema web durante el curso académico 2017/18.

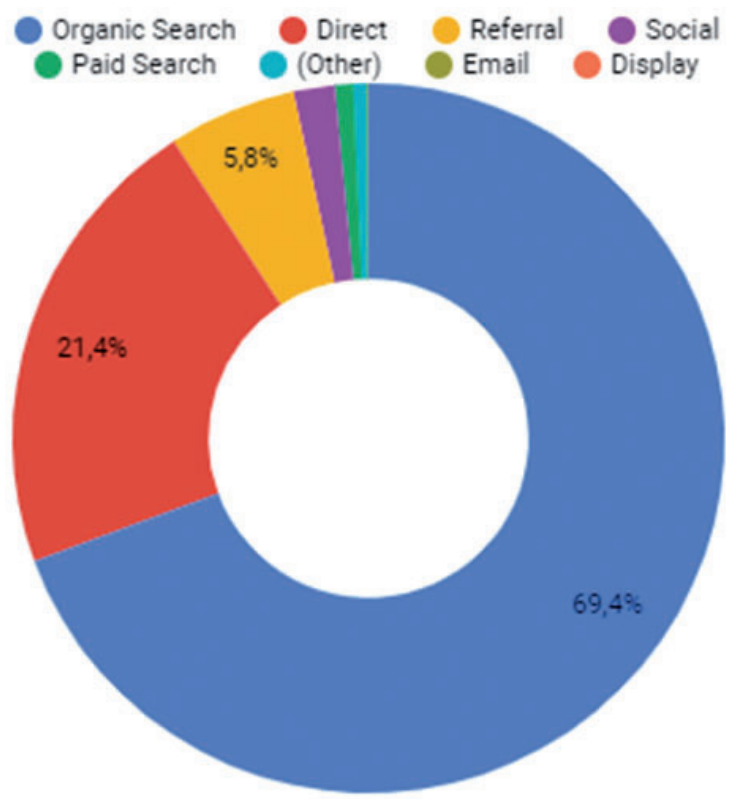

Figura 3. Canales de tráfico, a través de disositivos móviles, a la web de la universidad

Fuente: Google Data Studio 
En la figura 3, se muestran ejemplos de trabajo relacionados con el SEO móvil. En este ámbito se han desarrollado versiones AMP de las páginas de eventos del sitio web de la universidad, así como de los posts de la red de blogs, con el objetivo de disponer de versiones más ligeras para que Google las indexe en posiciones privilegiadas. Un ejemplo de entrada indexada en formato AMP responde a la búsqueda: «Congreso Internacional de Estudiantes», formulada desde un BQ Aquaris X. Se puede observar el icono de un rayo, a la izquierda de la URL, que indica que la entrada se va a mostrar en formato AMP (figura 4).

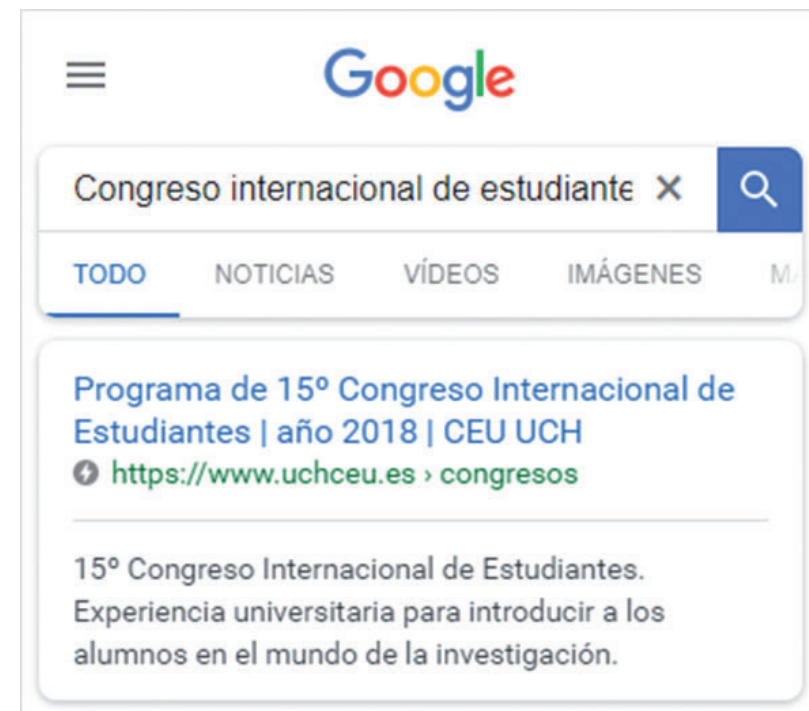

Figura 4. Resultado de la búsqueda en formato AMP en Google desde smartphone

Fuente: Google Data Studio

También se ha trabajado el contenido de diversos posts de los blogs con el objetivo de aparecer en fragmentos destacados, ya que este formato enriquecido aparece por encima de cualquier resultado orgánico. Para lograrlo, hay que intentar reproducir en el post la pregunta que los 
usuarios formulan cuando realizan la búsqueda, y responderla a continuación de forma concisa y clara. El segundo método consiste en trabajar la composición de las palabras clave con el objetivo de responder a preguntas más específicas -las llamadas «consultas de larga cola»- propias de las búsquedas por voz.

Se puede observar un ejemplo de este trabajo en el post: Reactivo de Fehling, del blog de Epónimos Científicos. En este caso, además de formular la palabra clave correcta en su titular-reactivo de Fehling-y una respuesta adecuada de forma inmediata, ha sido posible la aparición en Google como fragmento destacado debido a la escasa competencia que existe para esa palabra clave (figura 5).

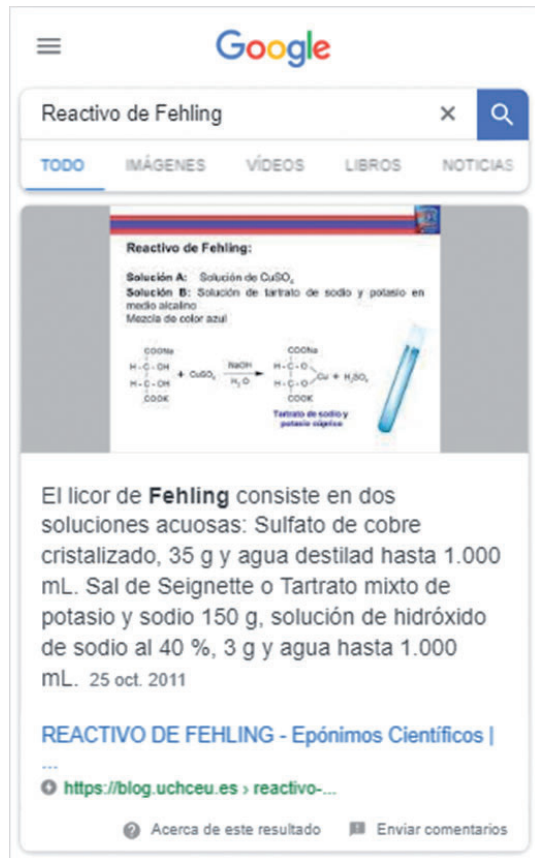

Figura 5. Resultado de la búsqueda en formato de fragmento destacado en Google desde smartphone

Fuente: Google 
Cabe destacar que, según los informes obtenidos en Google Analytics, el post del reactivo de Fehling, pese a publicarse en el año 2011, es el que más tráfico recibió a través del canal orgánico de toda la red de blogs de la universidad durante el curso académico 2017/18. Concretamente, 16.501 visitas a través de búsquedas en Google frente a las 9.111 del segundo post más visitado: «10 consejos para el acto de defensa pública del TFG», del blog de Dirección de Empresas.

Este último post es un buen ejemplo para probar el funcionamiento de las búsquedas de larga cola y las búsquedas por voz a través de un dispositivo móvil. Se trata de trabajar el contenido mediante el uso de palabras clave que respondan a preguntas más específicas para diferenciarse de los competidores. En este caso, la pregunta realizada por voz al dispositivo móvil ha sido: ¿Me das consejos para el acto de defensa pública del TFG? La respuesta de Google ha sido la siguiente (figura 6):

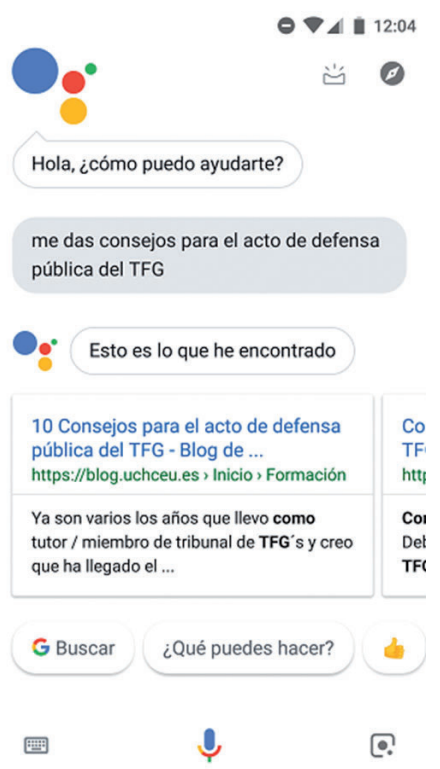

Figura 6. Resultado de la búsqueda por voz en Google desde smartphone Fuente: Google 


\subsection{Social media}

La universidad tiene, desde hace años, cuentas activas de las principales redes sociales: Facebook, Twitter, LinkedIn, YouTube o Flickr, cada una dirigida a un público objetivo distinto. No obstante, en este artículo se pretenden mostrar acciones realizadas con redes sociales móviles, como Instagram, red nativa móvil con la que se empezó a trabajar a finales de 2016.

Las publicaciones orgánicas en Instagram tienen el objetivo de conectar con el nuevo estudiante universitario, por ejemplo, tratando de hacerle partícipe de la vida universitaria a través de sus propias fotos o mediante la celebración de concursos de fotografía. Por tanto, no se busca generar conversión, sino engagement.

Por esta razón, los canales de Facebook siguen considerándose necesarios tanto para la difusión del contenido presentado en los blogs temáticos de la universidad, con enlaces a las páginas de las titulaciones universitarias relacionadas, o a la sección de solicitudes de admisión, entre otras. Además, debido a la todavía gran aceptación que tiene entre públicos objetivos de mayor edad -como estudiantes de posgrado, antiguos alumnos o padres de nuevos alumnos-, puede ser utilizado para difundir, por ejemplo, acciones solidarias realizadas por estudiantes, casos de éxito de antiguos alumnos, etc., buscando generar prescripción. Además, en el panel de control puede observarse que la penetración del canal en usuarios móviles supera claramente a los usuarios de la versión desktop (figura 7).

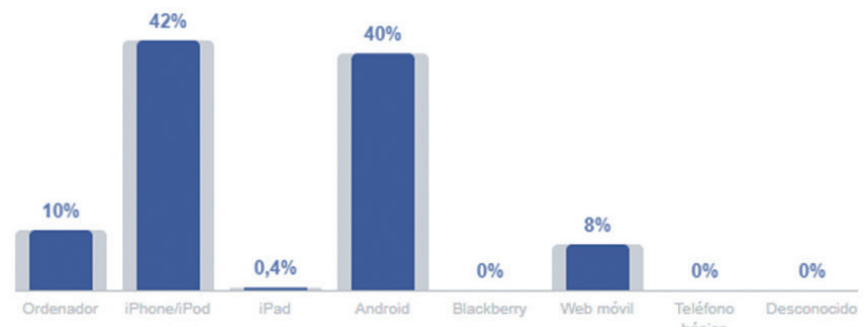

Figura 7. Dispositivos desde los que se visita el canal de Facebook de la Universidad

Fuente: Facebook 
También se observa la compatibilidad de ambas redes en función de los rangos de edad de los usuarios que visitan las publicaciones. En Facebook, los usuarios entre 25 y 34 años son los que más interactúan con el canal, seguido de los usuarios entre 35 y 44 años. Además, hay tantos seguidores de entre 45 y 54 años como de entre 18 y 24 (figura 8 ).

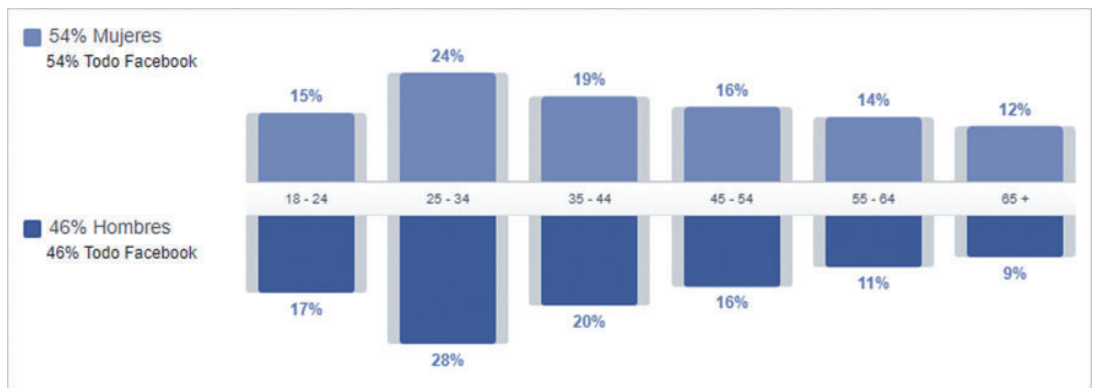

Figura 8. Rangos de edad de los visitantes del canal de Facebook de la Universidad

Fuente: Facebook

Sin embargo, los seguidores de la cuenta de Instagram entre 18 y 24 años son una mayoría clara. Un $57 \%$ de los 4.128 seguidores que tiene la cuenta a 1 de septiembre de 2018.
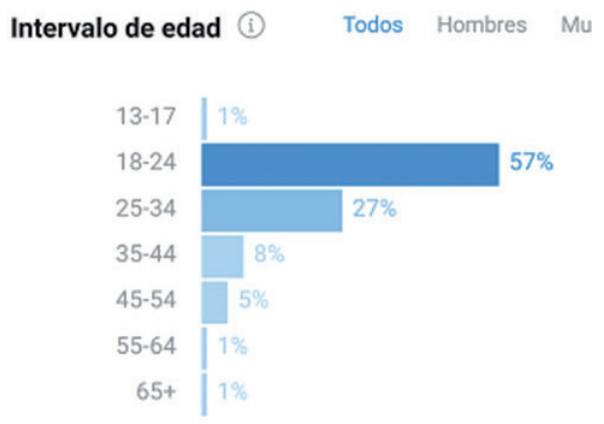

Figura 9. Rangos de edad de los seguidores del canal de Instagram de la Universidad

Fuente: Instagram 


\subsection{Acciones dinámicas de campaña estacionales}

El primer recurso que enumerar es el marketing en buscadores al comienzo de las campañas de admisión de grado y posgrado, o a principio de curso para intentar captar a los estudiantes rezagados. Se muestra, a continuación, un ejemplo de este último caso mediante un anuncio de Google Adwords, que dirige a los usuarios a una página de aterrizaje con un formulario para solicitar información sobre cualquier titulación de la oferta académica. Como se puede observar, introduciendo en la búsqueda las palabras clave de marca: Universidad cEu Cardenal Herrera, esta entrada aparece por encima de todos los resultados orgánicos, lo que convierte al SEO en una estrategia fundamental para lograr objetivos de conversión inmediatos.

Para lograr el posicionamiento a través de palabras clave genéricas, la posición del anuncio dependerá del precio pagado por el mismo y de la competencia frente a otros anuncios que pujen por palabras clave similares. En este caso, se muestra un ejemplo para las palabras clave: «Becas en Valencia 2018», que también muestra un anuncio en la primera posición del buscador (figura 10). En este caso, el anuncio redirige a una página de aterrizaje que, además del formulario, presenta información personalizada sobre las becas ofrecidas por la universidad. Ambos anuncios han sido configurados en Google Adwords para impactar sobre usuarios de la Comunidad Valenciana, entre 18 y 25 años, que naveguen a través de dispositivos móviles.

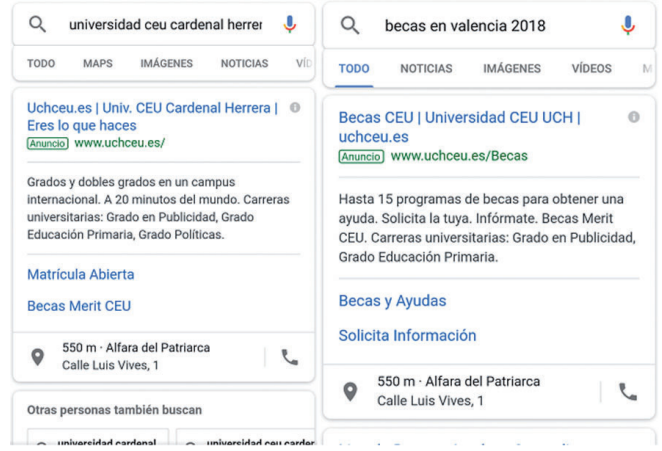

Figura 10. Resultados de anuncios de búsqueda con Adwords desde smartphone Fuente: Google 


\subsection{Anuncios pagados en redes sociales}

Del mismo modo que se ha procedido con las publicaciones orgánicas, se han seleccionado los canales de Facebook e Instagram para publicar anuncios que, además, desde la compra de Instagram por parte de Facebook (Rodríguez 2012), se visualizan en el administrador de anuncios de Facebook. El formato de los anuncios es generalmente de tipo imagen o vídeo, pero en esta ocasión, se añade un enlace a una página de aterrizaje, con el objetivo de lograr leads, tanto en Facebook como en Instagram. El propósito es comparar tres KPI entre las dos redes sociales: el alcance, el número de clics al call-to-action, y el precio de cada clic.

Se ha realizado una comparación entre la media de los KPI indicados de las publicaciones promocionadas en Facebook móvil, Instagram e Instagram Stories desde el 1 de junio al 31 de agosto de 2018 (tabla 1).

Tabla 1. Métricas desde los canales de Facebook e Instagram

\begin{tabular}{lcccc}
\hline & Anuncios & $\begin{array}{c}\text { Alcance por } \\
\text { anuncio }\end{array}$ & $\begin{array}{c}\text { Clics por } \\
\text { anuncio }\end{array}$ & $\begin{array}{c}\text { Coste } \\
\text { por clic }\end{array}$ \\
\hline Facebook móvil & 22 & 9.623 personas & 226 & $0,32 €$ \\
\hline Instagram & 16 & 12.790 personas & 136 & $0,91 €$ \\
\hline Instagram Stories & 14 & 16.428 personas & 269 & $0,28 €$ \\
\hline
\end{tabular}

Fuente: Elaboración propia

Con estos datos observamos que, si bien las noticias en Instagram no tienen la misma efectividad que Facebook para lograr leads, las Stories superan a Facebook en rentabilidad, medida en coste por clic.

\subsection{Campañas de display}

Se han realizado diversas creatividades en periodos de campaña que se han mostrado en sitios web diversos como Outlook, Educaweb, El Mundo, El País o Marca. El objetivo de los anuncios es generar leads 
mediante un enlace una página de aterrizaje con un formulario para solicitar información sobre alguna titulación. Las creatividades se han diseñado tanto en formato escritorio como móvil, siendo estas últimas las que más visionados y tasas de clic presentan. Pese a ello, no se ha probado hasta el momento con anuncios inApp o durante descargas de aplicaciones.

\subsection{Campañas de email marketing}

Gracias al CRM, la universidad posee una base de datos detallada de usuarios que han solicitado información o admisión a la universidad. Cuando se organiza un evento, como una jornada de puertas abiertas o un seminario web gratuito, se utilizan listas de marketing segmentadas por los parámetros elegidos y se generan campañas automatizadas para enviar formularios de inscripción, correos electrónicos recordatorio o encuestas post-evento al smartphone de los estudiantes potenciales mediante la plataforma de automatización de marketing. La propia plataforma incorpora un asistente para generar plantillas con un diseño mobile-first, así como un módulo de estadísticas en las que se notifica la interacción de los usuarios con cada una de las acciones de marketing realizadas durante el proceso.

En el ejemplo (figura 5), se puede observar el número de flujos finalizados para las distintas campañas. La campaña sombreada es una jornada de puertas abiertas en Valencia, cuyas acciones de marketing han sido enviadas a 2.811 estudiantes potenciales.

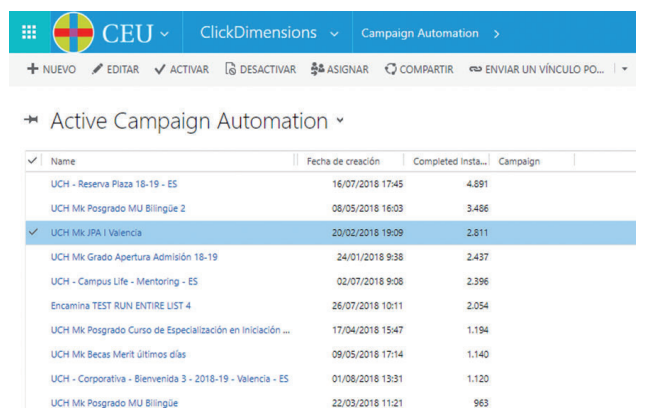

Figura 5. Resultados de automatizaciones de campaña realizados Fuente: ClickDimensions 


\subsection{Informe del focus group}

Finalmente, queda mostrar el informe de la dinámica de grupo con los estudiantes, de la que se extraen los siguientes resultados:

Sobre las plataformas de comunicación empleadas durante el proceso de captación de los estudiantes, se llegó a la conclusión de que la web y los anuncios a través de Facebook habían sido los más efectivos, por encima de los anuncios a través de Instagram, red empleada durante el curso 2016/17 para una única campaña de prueba. Cabe destacar el desconocimiento generalizado de la existencia de los blogs como plataforma para transmitir contenido de valor para potenciales estudiantes. Por otra parte, el correo electrónico y la intranet fueron señalados como los medios más adecuados para establecer relaciones individualizadas a través del móvil -aquí hubo consenso acerca de la necesidad de mejorar la usabilidad móvil de la intranet-aunque también se reconoció el acceso a través del ordenador de forma puntual.

Ya matriculados, los estudiantes coinciden en la disminución de la importancia de la web frente a la intranet como herramienta de trabajo habitual, aunque siguen otorgando gran importancia a las redes sociales de la universidad, que visitan a través de su móvil. El orden de preferencia es Instagram, Facebook y Twitter. En cuanto al tipo de uso, afirman no tener reparos en utilizar los canales online de la universidad para expresar dudas y quejas, aunque reconocen no conectar con el lenguaje empleado por esta. Consideran que es, en ocasiones, demasiado institucional, por lo que reclaman un mayor protagonismo de los alumnos. Por otra parte, ven Snapchat como una red social para ocio, pero aún no como un canal interesante para ser explotado por la universidad. Actualmente sí que hay un reconocimiento hacia los blogs como plataforma para encontrar información sobre su área de interés y, aunque no es el objetivo del estudio, cabe indicar que tres estudiantes se identificaron como autores de posts en el blog de su titulación. 


\section{CONCLUSIONES}

La presente comunicación demuestra que la Universidad CEU Cardenal Herrera utiliza las herramientas de marketing y comunicación móviles a su alcance para impactar en sus públicos objetivos, pero hay aún mucho margen de mejora. En primer lugar, hay que seguir fomentando la participación de los estudiantes en los canales de comunicación y hacerles sentirse protagonistas y partícipes de la comunicación universitaria, además de seguir trabajando en la usabilidad móvil de las plataformas de comunicación online con ellos.

Por otra parte, el uso de las nuevas herramientas digitales de comunicación sigue aumentando entre los estudiantes y la universidad debe estar presente en todos. Las universidades norteamericanas siguen yendo un paso por delante y marcando el camino a seguir. Además, el marketing móvil es una disciplina aún emergente y, con la próxima consolidación del internet de las cosas, van a abrirse un mundo de posibilidades.

Como trabajo futuro más inmediato, se plantea la instalación de beacons en los edificios de los distintos campus del ceu, junto al desarrollo de una aplicación móvil para poder realizar acciones de marketing de proximidad, el gran olvidado en la estrategia de marketing móvil de la universidad. Estas balizas permitirán enviar notificaciones push a los dispositivos móviles de los usuarios que entren en el campus para asistir, por ejemplo, a las jornadas de puertas abiertas a las que han sido invitados mediante las campañas automatizadas. En ese momento recibirán información de interés, como la hora y el lugar exacto en el que se celebra el evento. Para lograr la descarga de la aplicación móvil por parte de los usuarios, se enviarán diversos correos electrónicos durante la campaña incitando a su descarga a través de un enlace.

\section{BIBLIOGRAFÍA}

Acebes, B., C. Mozas, R. Montanera y V. Julià. 2018. Estudio Anual de Redes Sociales 2018. Madrid: IAB Spain. 
Adams, L., E. Burkholder y K. Hamilton. 2015. Micro-Moments: Your Guide to Winning the Shift to Mobile, Think With Google.

An, D. 2018. Find out how you stack up to new industry benchmarks for mobile page speed. http://cort.as/-E6ee

Becker, M. y J. Arnold. 2010. Mobile marketing for dummies. John Wiley \& Sons Ltd.

Castells, M. 2009. Comunicació i poder, 14. Editorial uoc.

Cooper, T. 2017. «How To Appear In Google's Featured Snippet In 2017 (Knowledge Graph)». Higher Ed Marketing Journal. http://cort.as/E6ek

De Kerckhove, D. y C. Dewdney. 1999. La piel de la cultura: investigando la nueva realidad electrónica. Gedisa Editorial.

Dean, B. 2018. «We Analyzed 10.000 Google Home Results. Here's What We Learned About Voice Search SEO». Backlinko. http://cort. as/-E6em

Diego, V. J. R. «Modelo de comunicación corporativo online en el sector universitario». Doxa Comunicación. Revista Interdisciplinar de Estudios de Comunicación y Ciencias Sociales, 7: 197.

Dushinski, K. 2012. The Mobile Marketing Handbook: A Step-by-Step Guide to Creating Dynamic Mobile Marketing Campaigns. Medford: CyberAge Books.

Optimization. Sebastopol: O'Reilly Media.

Enge, E., S. Spencer y J. Stricchiola. 2015. The Art of SEO. 2015.

Gilliland, N. 2017. «How Higher Education Providers are Marketing to New Students». Econsultancy. http://cort.as/-E6er

Google. 2016. AMP Project. www.ampproject.org

Hamblen, M. 2015. «Oklahoma Sooners use Beacons, Sensors to Find Rooms on Massive campus». Computer World. http://cort.as/-E6ey Hanover Research. 2015. 2016 Trends in Higher Education Marketing, Enrollment and Technology. Arlington: Hanover Research. www. hanoverresearch.com

Harley, E. 2014. «Instant Messaging Apps for Higher Education Marketing and Communications: Snapchat». Picklejar Communications. http:// cort.as/-E6f0 
Hayes, T. J. y M. M. Walker. 2012. «A Mobile Market: Opportunities and Strategies in Higher Education». International Journal of Technology and Educational Marketing (IJTEM), 2 (2): 55-69.

Higher Education Marketing. 2016. «3 Key Areas to Update, Upgrade, and Upscale your School's SEO Strategy». Higher Education Marketing. http://cort.as/-E6f3

—. 2017. «Choosing the Righ PPC Channels for your Higher Education Paid Advertising Campigns». Higher Education Marketing. http:// cort.as/-E6f7

Himanen, P. 2002. La ética del hacker y el espíritu de la era de la información.

Hopkins, J. y J. Turner. 2012. Go Mobile: Location-Based Marketing, Apps, Mobile Optimized Ad Campaigns, 2D Codes and Other Mobile Strategies to Grow Your Business. John Wiley \& Sons Ltd.

Jenkins, H. 2006. Convergence Culture: Where Old and New Media Collide. NYU press.

Joly, K. (2 de abril de 2012). «University of Notre Dame Redefines Highered Websites With its Redesigned Mobile First Responsive Homepage». College Web Editor. http://cort.as/-E6fB

—. 2016. «Time to AMP Your College Website?» University Business. http://cort.as/-E6fH

Kolowich, L.2017. «The 17 Best College Instagram Accounts (And Why They're So Darn Good)». Hubspot. http://cort.as/-E6fQ

Krum, C. 2010. Mobile Marketing: Finding Your Customers no Matter Where They Are. Pearson Education.

Kuzma, J. M. y W. Wright. 2013. «Using Social Networks as a Catalyst for Change in Global Higher Education Marketing and Recruiting». International Journal of Continuing Engineering Education and Life Long Learning, 23 (1): 53-66.

Lawlor. 2017. «Our Projects. Enrollment Management for Proospective Students». Lawlor. http://cort.as/-E6fc

Lawson, M. 2017. «4 Things You Need to Know About the Future of Marketing». Think with Google. http://cort.as/-E6fg 
Makino, T. y D. Phan. 2015. «Rolling Out the Mobile-Friendly Update». Official Google Webmaster Central Blog, 21.

Marcotte, E. 2011. Responsive web design. New York: A Book Apart. Mobile Marketing Association. 2009. «MMA Updates Definition of Mobile marketing». Mobile Marketing Association. http://cort.as/E6fq

Modo Labs. 2015. «The 10 Best University Mobile Apps of 2015». Modo Labs. http://cort.as/-E6ft

Newberry, C. 2018. «Social Media Advertising 101: How to Get the Moof your Budget». Hootsuite. http://cort.as/-E6fu

Newman, N. 2014. «Apple iBeacon Technology Briefing». Journal of Direct, Data and Digital Marketing Practice 15 (3): 222-225.

Nielsen. 2013. «Paid Social Media Advertising. Industry Update and Practices 2013». Nielsen. http://cort.as/-E6fz

Noel Levitz, R. 2017. 2017 Marketing and Student Recruitment Report of Effective Practices. Iowa: Ruffalo Noel Levitz. RuffaloNL.com/ BenchmarkReports

O'Reilly, T. 2005. What is Web 2.0.

Ratliff, A. 2011. «Are They Listening? Social Media on Campuses of Higher Education». The Journal of Technology in Student Affairs, 38. Rodríguez, S. 2012. «Facebook compra Instagram por 1.000 millones de dólares». El Mundo. http://cort.as/-E6g3

Rowles, D. 2013. Mobile Marketing: How Mobile Technology is Revolutionizing Marketing, Communictions and Advertising. London: Kogan Page Publishers.

Runyon, E. 2018. «HigherEd RWD Directory». Erick Runyon. http:// cort.as/-E6g5

Scolari, C. 2008. Hipermediaciones: elementos para una teoría de la comunicación digital interactiva. Editorial Gedisa.

Shein, E. 2015. «Why Colleges Must Go Mobile-First». University Business. http://cort.as/-E6g7

Smarty, A. 2017. «How to Optimize for Google's Featured Snippets to Build More Traffic». Moz. http://cort.as/-E6gG 
Štefko, R., R. Fedorko y R. Bačík. 2015. «The Role of E-marketing Tools in Constructing the Image of a Higher Education Institution». Procedia-Social and Behavioral Sciences, 175: 431-438.

Stoller, E. 2017. «Cambridge University - Crushing It On Social Media». Inside Higher Ed. http://cort.as/-E6gK

TrackMaven. 2017. The 2017 Digital Marketing Analytics Performance Report. Washington D.C.

Wrobleski, L. 2011. Mobile first. New York: A Book Apart. 


\title{
LA INTERACCIÓN ENTRE LAS MARCAS Y SUS SEGUIDORES EN FACEBOOK: EL CASO DE HUGO BOSS
}

\author{
Marián NaVArRo-Beltrá \\ Universidad Católica de Murcia (UCAM) \\ Susana Miquel-Segarra \\ Universitat Jaume I de Castellón \\ Irene García Medina \\ Glasgow Caledonian University
}

\section{Resumen}

Los medios sociales han cambiado la forma que las organizaciones tienen de comunicarse con sus públicos, de hecho, el uso masivo de internet conlleva que la unidireccionalidad deje paso a la bidireccionalidad. En concreto, las redes sociales posibilitan que las empresas mantengan un diálogo directo con sus clientes, de forma que Facebook es utilizado con frecuencia por estas instituciones para promocionar sus productos o marcas. Así, las marcas de lujo suelen tener una estrategia digital definida que incluye el uso de las redes sociales con el propósito de interactuar con sus seguidores. Ante este contexto cabe mencionar a Hugo Boss, ya que se trata de una marca de lujo con una destacada presencia en redes sociales. Por tanto, el objetivo de este trabajo se basa en analizar el diálogo que Hugo Boss mantiene con sus seguidores en Facebook. Para ello, se ha efectuado un análisis de contenido de las repercusiones (reacciones, contenido compartido, comentarios de los seguidores y respuestas por parte de la marca) de 163 publicaciones realizadas por Hugo Boss en Facebook en 2017. Los principales resultados de este trabajo ponen de manifiesto que todas las publicaciones generan reacciones, que la mayoría son compartidas y que los seguidores normalmente realizan comentarios, aunque la marca no suele responder. Cabe destacar que, de manera significativa, Hugo Boss responde con menor frecuencia a los comentarios que sus fans realizan en publicaciones con poca repercusión (bajo número de reacciones, de comentarios y escasamente compartido). De esta 
forma, a mayor número de reacciones, de comentarios y de contenido compartido, más respuestas por parte de la marca. Por tanto, y para concluir, se podría afirmar que Hugo Boss suele interactuar y dialogar con sus seguidores principalmente en aquellos posts que poseen una mayor repercusión.

Palabras clave: Facebook; redes sociales; diálogo; comunicación corporativa; Hugo Boss.

\section{INTRODUCCIÓN}

E PODRÍA CONSIDERAR QUE INTERNET HA modificado el ecosistema mediático, de manera que este ha evolucionado rápidamente y ahora es más dinámico que nunca (Orbea, Iglesias y Papí 2014). Dentro de este nuevo paradigma comunicativo llaman especialmente la atención los social media, que podrían definirse como

la comunicación interpersonal colectiva vía internet por medio de aplicaciones web o dispositivos móviles de manera síncrona y/o asíncrona por parte de micromedios (multi)descentralizados, (des)localizados, (co)generativos con capacidad de articular un feedback y de autoorganizarse, hacia audiencias en constante reconfiguración, sin un alcance geográfico preestablecido de un conjunto no recurrente, no normalizado y heterogéneo de contenidos simbólicos o mensajes (propios o de terceros) no sujetos a una agenda performativa (Del Fresno 2012).

De manera más sencilla podría decirse que los social media «son un conjunto de plataformas digitales que permiten la creación y el intercambio de contenidos generados por el usuario y que se desarrollan sobre los fundamentos [de] la Web 2.0» (Escandell e Iglesias 2014). Dentro de los medios sociales se pueden encontrar blogs, redes sociales, mundos virtuales, etc., de forma que se incluye cualquier soporte que permita a sus usuarios crear y compartir contenido (IAB 2009). Estos soportes permiten crear canales de comunicación próximos al público objetivo, conseguir un feedback inmediato capaz de establecer un diálogo entre la marca y el consumidor y desarrollar estrategias publicitarias menos 
intrusivas que las tradicionales (Escandell e Iglesias 2014). Por tanto, se podría considerar que los medios sociales han cambiado la forma que las organizaciones tienen de comunicarse con sus públicos, de hecho, el uso masivo de internet conlleva que la unidireccionalidad deje paso a la bidireccionalidad (Aced 2013).

Dentro de los social media llaman especialmente la atención las redes sociales. «Una red social es un grupo de personas que tienen algo en común y es por ese algo por lo que se conocen y se agrupan para interactuar y estar en contacto» (Castelló 2010). Estas personas pueden relacionarse de manera física o virtual, pero esta relación es lo que les permite conectar entre sí con fines diversos y en función de sus intereses, que pueden ser profesionales, personales, de ocio... (Aced 2013). Así, las redes sociales online favorecen el establecimiento de relaciones con otros usuarios a los que se puede, o no, conocer en la realidad (Castelló 2010). De esta forma, una comunidad virtual, o red social, es un «sitio web que permite crear un perfil personal, ponerse en contacto con el resto de miembros que forman parte de la red y compartir contenido con ellos» (Aced 2010). Sin embargo, cabe destacar que, para que se llegue a crear comunidad, es indispensable que exista un sentimiento de pertenencia entre sus miembros y que se compartan intereses y afinidades (Aced 2013).

En concreto, las redes sociales posibilitan que las empresas mantengan un diálogo directo con sus clientes (Viadana et al. 2011), de forma que Facebook es utilizada con frecuencia por estas instituciones para promocionar sus productos o marcas (Cheung y Leung 2016). En este contexto, destaca que los consumidores adquieren más poder que las marcas y que la comunicación empresarial cambia, de manera que es posible crear comunidad y «recuperar las relaciones humanas en el ámbito del consumo» (Alonso 2015). En este sentido, cabe señalar que hoy en día para retener al consumidor no basta con explicar, es necesario que aquello que se narra sea interesante, de manera que se ha pasado del storytelling al engaging (Roca 2014).

Específicamente, el sector de la moda debe impulsar la creación de comunidades a través de lugares de encuentro donde los usuarios que 
posean intereses comunes puedan compartir sus experiencias, ya que las experiencias compartidas, aunque sean efímeras, generan un sentimiento de pertenencia y comunidad (Domingo 2013). Esta industria llama especialmente la atención porque no todos los sectores han accedido al ámbito digital con la misma inversión y presencia y es la industria de la moda la que destaca por su intensa presencia en social media, su abundante uso de plataformas de generación de contenido y por su elevada facturación a través del comercio electrónico (Fondevila, Del Olmo y Bravo 2012). En este contexto, y ante la existencia de un mercado hiperconectado e hiperfragmentado, es fundamental que las marcas de moda gestionen su comunicación en el ámbito digital, de manera que se busquen nuevos códigos y formas que se alejan de la comunicación tradicional con el propósito de conectar con sus públicos (Domingo 2013).

Dentro de la industria de la moda destaca el caso de Hugo Boss, ya que se trata de una marca de lujo con una destacada presencia en redes sociales (García Medina Miquel Segarra y Navarro Beltrá 2018). En concreto, al hablar de lujo se hace referencia a aquel sector que se relaciona con la exclusividad, que posee precios elevados y que cuenta con vivencia de experiencias u objetos fuera de lo habitual (Colombo y Castrillón 2010).

Es frecuente que las marcas de lujo tengan una estrategia digital definida que incluya el uso de las redes sociales con el propósito de interactuar con sus seguidores (Del Pino Romero y Castelló Martínez 2015 , 120). Esta situación se produce a pesar de que los medios sociales son masivos y, por tanto, podría considerarse que su utilización atenta contra la supuesta exclusividad de este tipo de organizaciones (Colombo y Castrillón 2019) y que la accesibilidad de estas empresas en internet podría mermar esta imagen de exclusividad (Del Pino Romero y Castelló Martínez 2015). Sin embargo, la presencia de estas marcas en la red conlleva oportunidades muy valiosas para hablar sobre su historia, su trayectoria y sus atributos especiales, de manera que se potencia la conexión con la institución, especialmente si se tienen en cuenta las posibilidades de interactividad (Colombo y Castrillón 2010). 
En este sentido, cabe destacar que Facebook se considera la principal plataforma social para las marcas de moda, sobre todo por su gran au-

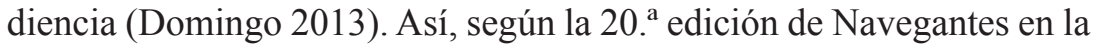
Red (AIMC 2018), Facebook es la red social más utilizada, ya que el $85,6 \%$ de los participantes en el estudio accedió a esta plataforma en los últimos 30 días. Instagram, que es la siguiente red social más usada, se sitúa a gran distancia, pues únicamente el 47,1 \% de los encuestados accedió a esta red social en los últimos 30 días.

Por su parte, el Estudio Anual de Redes Sociales (IAB 2018) también concluye que Facebook, aunque en este caso junto a WhatsApp, es la red social más utilizada, pues el $87 \%$ de los entrevistados la usan. Además, Facebook también es la red social con mayor notoriedad, ya que es la que proporciona un mayor conocimiento espontáneo $(96 \%)$ y sugerido (96\%) entre los entrevistados (IAB 2018). En este sentido, no se puede olvidar que cada vez es más habitual que la población utilice las redes sociales para buscar información sobre productos antes de efectuar una compra y destaca el hecho de que Facebook es el canal principalmente utilizado para ello (IAB 2018).

De esta forma, podría considerarse que Facebook es una red social horizontal $^{7}$ que resulta apropiada para frecuentar contactos, generar fidelidad hacia un producto o marca y crear comunidad (Merino Bobillo, Lloves Sobrado y Pérez Guerrero 2013). Así, cabe destacar que las investigaciones previas evidencian que la interacción que se genera a través de las opciones más básicas de Facebook (uso de reacciones, comentarios y compartir contenido) es una valiosa fuente de información respecto al grado de implicación de sus seguidores (Merino Bobillo, Lloves Sobrado y Pérez Guerrero 2013). Gracias a estos datos, las marcas pueden conocer qué es lo que sus clientes buscan y qué es lo que más les gusta (Alonso

7. Según la temática que traten, las redes sociales pueden ser horizontales, como Google+ o Facebook, o verticales, es decir, especializadas en una temática concreta como, por ejemplo, la red profesional LinkedIn. Otra forma de clasificar las redes sociales es considerar si se centran en el usuario (Twitter o Facebook) o en objetos, es decir, en este último caso lo que importa es el material a compartir (Flickr o Youtube) (Aced 2013). 
2015) y adaptar, por tanto, su comunicación a las necesidades y gustos de sus públicos.

\section{OBJETIVOS}

Por tanto, el objetivo de este trabajo se basa en analizar la interacción y el diálogo que Hugo Boss mantiene con sus seguidores en Facebook. En concreto, se pretende examinar el uso de los botones de reacción por parte de los usuarios («me gusta», «me encanta»...), la existencia de contenido compartido, el uso de preguntas por parte de la marca, la existencia de comentarios efectuados por los seguidores y las respuestas a estos comentarios por parte de la marca.

\section{METODOLOGÍA}

Para cumplir con los objetivos indicados anteriormente se recurrió a la metodología cuantitativa. En concreto, se efectuó un análisis de contenido de las publicaciones realizadas por Hugo Boss en Facebook entre el 1 de enero y el 30 de junio de 2017 y se prestó especial atención a las repercusiones que obtuvieron estos posts (reacciones, contenido compartido, comentarios de los seguidores y respuestas por parte de la marca). Para localizar las publicaciones realizadas por Hugo Boss en Facebook se recurrió al perfil internacional de la marca, ${ }^{8}$ cabe destacar que este contaba con el calificativo de página verificada.

Al seleccionar los post efectuados por Hugo Boss en las fechas indicadas previamente se obtuvo un total de 163 publicaciones, todas ellas fueron analizadas para la realización de este estudio. Para codificar estos posts se diseñó y aplicó un amplio protocolo de codificación, aunque la realización de esta investigación se centra en aquellas variables que examinan la repercusión que las publicaciones han causado en sus

8. Se puede acceder a este perfil a través del siguiente enlace: http://cort.as/-EAD8 
receptores. De esta forma, y para efectuar el presente análisis, se examinó el número y el tipo de reacciones ocasionadas («me gusta», «me encanta»...), el número de veces que se compartió el contenido, el uso de preguntas directas por parte de la marca en las publicaciones y sus consecuencias en función de los comentarios realizados por los seguidores y las respuestas de Hugo Boss a estas interacciones.

Con el propósito de analizar esta información, se utilizó el programa informático sPSS versión 24. En concreto, se recurrió a las frecuencias, a los descriptivos, a las tablas de contingencia y a las correlaciones.

\section{RESULTADOS}

A pesar de que en el periodo analizado Hugo Boss no suele incorporar una gran cantidad de publicaciones en Facebook, ya que cuenta con menos de un post diario, cabe señalar que los usuarios sí suelen interactuar con ellas. De hecho, todas las publicaciones generan reacciones, la mayoría son compartidas y los seguidores de la marca normalmente realizan comentarios, aunque la organización no suele responder.

$\mathrm{Al}$ analizar estos datos con detalle destaca que los post examinados generan una media de 2.508,93 reacciones, siendo 22 el mínimo de reacciones que obtiene una publicación y 16.779 el máximo (véase tabla 1). La reacción que más se utiliza es «me gusta», ya que de media se puede observar en 2.398,96 ocasiones por post (con un mínimo de 21 y un máximo de 16.171). Solo hay otra reacción que también se muestra en todas las publicaciones, «me encanta», aunque su uso es considerablemente inferior. En concreto, esta reacción es utilizada por los usuarios una media de 94,19 veces por post (con un mínimo de 1 y un máximo de 508).

Por su parte, destaca que el 95,7 \% de las publicaciones son compartidas por los seguidores de la marca, de hecho, una de ellas lo fue hasta en 775 ocasiones, lo que supone una media de 131,20. En este sentido, cabe señalar que el 92,6 \% de los posts genera comentarios por parte de los usuarios y que estos llegan a una media de 93,91. Así, destaca la 
existencia de una publicación que obtiene 1.136 comentarios, se trata en una sesión de preguntas y respuestas en directo con Alex Thomson, un regatista profesional que es patrocinado por Hugo Boss. Sin embargo, y a pesar de estos datos, la marca solamente realiza comentarios en el 23,3\% de los posts e incluye como máximo 4 en la misma publicación, lo que supone una media de 0,44 (tabla 1 ).

Tabla 1. Interacciones entre la marca y los usuarios

\begin{tabular}{|c|c|c|c|}
\hline Tipo de interacción & Media & Mínimo & Máximo \\
\hline $\mathrm{N}^{\mathrm{o}}$ total de reacciones & $2.508,93$ & 22 & 16.779 \\
\hline $\mathrm{N}^{\mathrm{o}}$ de «me gusta» & $2.398,96$ & 21 & 16.171 \\
\hline $\mathrm{N}^{0}$ de «me encanta» & 94,19 & 1 & 508 \\
\hline $\mathrm{N}^{0}$ de «me divierte» & 2,60 & 0 & 39 \\
\hline $\mathrm{N}^{\mathrm{o}}$ de «me asombra» & 11,75 & 0 & 80 \\
\hline $\mathrm{N}^{\mathrm{o}}$ de «me entristece» & 0,51 & 0 & 6 \\
\hline $\mathrm{N}^{\mathrm{o}}$ de «me enfada» & 0,74 & 0 & 9 \\
\hline $\mathrm{N}^{\mathrm{o}}$ de «orgullo LGBT» & 0,09 & 0 & 4 \\
\hline $\mathrm{N}^{\mathrm{o}}$ de «me enorgullece» & 0,05 & 0 & 2 \\
\hline $\mathrm{N}^{0}$ de veces compartido & 131,20 & 0 & 775 \\
\hline $\begin{array}{l}\mathrm{N}^{o} \text { de comentarios por parte } \\
\text { de los seguidores }\end{array}$ & 39,91 & 0 & 1.136 \\
\hline $\mathrm{N}^{\circ}$ de comentarios por parte de la marca & 0,44 & 0 & 4 \\
\hline
\end{tabular}

Todas estas interacciones se producen a pesar de que la marca no suela tratar de fomentar el diálogo con sus seguidores al realizar preguntas en sus posts, ya que solamente se pueden observar en el 8,6\% de los casos. En este sentido, destaca que no se producen diferencias estadísticamente significativas en la cantidad de publicaciones que incluyen comentarios por parte de los usuarios en función de si la marca plantea, 
o no, alguna pregunta. Sin embargo, y a pesar de que las diferencias no son significativas, es importante señalar que en todos los casos en los que la marca realiza una pregunta, se pueden observar comentarios por parte de los seguidores (véase tabla 2).

Tabla 2. Publicaciones comentadas por los usuarios en función de si la marca plantea, o no, alguna pregunta en la publicación

\begin{tabular}{|c|c|c|c|c|}
\hline \multicolumn{2}{|c|}{$\begin{array}{c}\text { ¿La marca plantea alguna pregunta } \\
\text { en su publicación? }\end{array}$} & \multicolumn{2}{|c|}{$\begin{array}{c}\text { ¿Los seguidores } \\
\text { comentan la } \\
\text { publicación? }\end{array}$} & \multirow[t]{2}{*}{ Total } \\
\hline & & No & Sí & \\
\hline \multirow{4}{*}{ No } & Recuento & 12 & 137 & 149 \\
\hline & $\begin{array}{l}\% \text { de ¿la marca plantea alguna } \\
\text { pregunta en la publicación? }\end{array}$ & $8,1 \%$ & $91,9 \%$ & $100,0 \%$ \\
\hline & $\begin{array}{l}\text { \% de ¿los seguidores comen- } \\
\text { tan la publicación? }\end{array}$ & $100,0 \%$ & $90,7 \%$ & $91,4 \%$ \\
\hline & $\%$ del total & $7,4 \%$ & $84,0 \%$ & $91,4 \%$ \\
\hline \multirow{4}{*}{ Sí } & Recuento & 0 & 14 & 14 \\
\hline & $\begin{array}{l}\% \text { de ¿la marca plantea alguna } \\
\text { pregunta en la publicación? }\end{array}$ & $0,0 \%$ & $100,0 \%$ & $100,0 \%$ \\
\hline & $\begin{array}{l}\text { \% de ¿los seguidores comen- } \\
\text { tan la publicación? }\end{array}$ & $0,0 \%$ & $9,3 \%$ & $8,6 \%$ \\
\hline & $\%$ del total & $0,0 \%$ & $8,6 \%$ & $8,6 \%$ \\
\hline \multirow{4}{*}{ Total } & Recuento & 12 & 151 & 163 \\
\hline & $\begin{array}{l}\% \text { de ¿la marca plantea alguna } \\
\text { pregunta en la publicación? }\end{array}$ & $7,4 \%$ & $92,6 \%$ & $100,0 \%$ \\
\hline & $\begin{array}{l}\text { \% de ¿los seguidores comen- } \\
\text { tan la publicación? }\end{array}$ & $100,0 \%$ & $100,0 \%$ & $100,0 \%$ \\
\hline & $\%$ del total & $7,4 \%$ & $92,6 \%$ & $100,0 \%$ \\
\hline
\end{tabular}


Al analizar con más detalle los comentarios que Hugo Boss incluye en sus propias publicaciones, cabe destacar que, de manera significativa, la organización comenta con menor frecuencia aquellos posts que han ocasionado poca repercusión (bajo número de reacciones y de comentarios y contenido escasamente compartido). Así, y como se muestra en la tabla 3 , en el 75,2 \% de las ocasiones en las que la marca no interactúa, se pueden observar pocas reacciones por parte de los usuarios (entre 1 y 1.999) $\left(\mathrm{x}^{2}=146,960 ; \mathrm{p}=0,000\right)$. Además, la tabla 4 indica que las publicaciones que no han sido compartidas en ninguna ocasión no incluyen comentarios por parte de la empresa $\left(x^{2}=152,371, p=0,000\right)$, a pesar de que estos posts sí pueden haber sido comentados por sus seguidores. Así, Hugo Boss tampoco interactúa en aquellas publicaciones que no han generado ningún comentario por parte de los usuarios $\left(\mathrm{x}^{2}=111,126, \mathrm{p}=0,000\right)$ (véase tabla 5).

Tabla 3. Número de comentarios por parte de la marca en función del número de reacciones de los seguidores

\begin{tabular}{|c|c|c|c|c|c|c|}
\hline \multirow{2}{*}{\multicolumn{2}{|c|}{$\begin{array}{l}\text { Número de reacciones por } \\
\text { parte de los seguidores }\end{array}$}} & \multicolumn{5}{|c|}{ Número de comentarios por parte de la marca } \\
\hline & & Sin & Una & Tres & Cuatro & Total \\
\hline \multirow{4}{*}{$\begin{array}{l}\text { De } 1 \\
\text { a } 999\end{array}$} & Recuento & 53 & 3 & 0 & 0 & 56 \\
\hline & $\begin{array}{l}\% \mathrm{n} .^{\circ} \text { reacciones } \\
\text { por parte de los } \\
\text { seguidores }\end{array}$ & $94,6 \%$ & $5,4 \%$ & $0,0 \%$ & $0,0 \%$ & $100,0 \%$ \\
\hline & $\begin{array}{l}\% \text { de } n .^{\circ} \text { de comenta- } \\
\text { rios por parte de la } \\
\text { marca }\end{array}$ & $42,4 \%$ & $12,0 \%$ & $0,0 \%$ & $0,0 \%$ & $34,4 \%$ \\
\hline & $\%$ del total & $32,5 \%$ & $1,8 \%$ & $0,0 \%$ & $0,0 \%$ & $34,4 \%$ \\
\hline
\end{tabular}




\begin{tabular}{|c|c|c|c|c|c|c|}
\hline \multirow{2}{*}{\multicolumn{2}{|c|}{$\begin{array}{l}\text { Número de reacciones por } \\
\text { parte de los seguidores }\end{array}$}} & \multicolumn{5}{|c|}{ Número de comentarios por parte de la marca } \\
\hline & & $\begin{array}{c}\text { Sin } \\
\text { comentarios }\end{array}$ & Una & Tres & Cuatro & Total \\
\hline \multirow{4}{*}{$\begin{array}{l}\text { De } \\
1.000 \\
\text { a } 1.999\end{array}$} & Recuento & 41 & 6 & 0 & 0 & 47 \\
\hline & $\begin{array}{l}\% \mathrm{n} .^{\mathrm{o}} \text { reacciones por } \\
\text { parte de los } \\
\text { seguidores }\end{array}$ & $87,2 \%$ & $12,8 \%$ & $0,0 \%$ & $0,0 \%$ & $100,0 \%$ \\
\hline & $\begin{array}{l}\% \text { de } n .^{\circ} \text { de comenta- } \\
\text { rios por parte de la } \\
\text { marca }\end{array}$ & $32,8 \%$ & $24,0 \%$ & $0,0 \%$ & $0,0 \%$ & $28,8 \%$ \\
\hline & $\%$ del total & $25,2 \%$ & $3,7 \%$ & $0,0 \%$ & $0,0 \%$ & $28,8 \%$ \\
\hline \multirow{4}{*}{$\begin{array}{l}\text { De } \\
2.000 \\
\text { a } 2.999\end{array}$} & Recuento & 10 & 7 & 0 & 0 & 17 \\
\hline & $\begin{array}{l}\% \mathrm{n} .^{\mathrm{o}} \text { reacciones por } \\
\text { parte de los } \\
\text { seguidores }\end{array}$ & $58,8 \%$ & $41,2 \%$ & $0,0 \%$ & $0,0 \%$ & $100,0 \%$ \\
\hline & $\begin{array}{l}\% \text { de } .^{\circ} \text { de comenta- } \\
\text { rios por parte de la } \\
\text { marca }\end{array}$ & $8,0 \%$ & $28,0 \%$ & $0,0 \%$ & $0,0 \%$ & $10,4 \%$ \\
\hline & $\%$ del total & $6,1 \%$ & $4,3 \%$ & $0,0 \%$ & $0,0 \%$ & $10,4 \%$ \\
\hline \multirow{4}{*}{$\begin{array}{l}\text { De } \\
3.000 \\
\text { a } 3.999\end{array}$} & Recuento & 12 & 0 & 1 & 8 & 21 \\
\hline & $\begin{array}{l}\% \mathrm{n} .^{\mathrm{o}} \text { reacciones por } \\
\text { parte de los } \\
\text { seguidores }\end{array}$ & $57,1 \%$ & $0,0 \%$ & $4,8 \%$ & $38,1 \%$ & $100,0 \%$ \\
\hline & $\begin{array}{l}\% \text { de } n .^{o} \text { de comenta- } \\
\text { rios por parte de la } \\
\text { marca }\end{array}$ & $9,6 \%$ & $0,0 \%$ & $20,0 \%$ & $100,0 \%$ & $12,9 \%$ \\
\hline & $\%$ del total & $7,4 \%$ & $0,0 \%$ & $0,6 \%$ & $4,9 \%$ & $12,9 \%$ \\
\hline
\end{tabular}




\begin{tabular}{|c|c|c|c|c|c|c|}
\hline \multirow{2}{*}{\multicolumn{2}{|c|}{$\begin{array}{l}\text { Número de reacciones por } \\
\text { parte de los seguidores }\end{array}$}} & \multicolumn{5}{|c|}{ Número de comentarios por parte de la marca } \\
\hline & & $\begin{array}{c}\text { Sin } \\
\text { comentarios }\end{array}$ & Una & Tres & Cuatro & Total \\
\hline \multirow{4}{*}{$\begin{array}{l}\text { De } \\
4.000 \\
\text { a } 4.999\end{array}$} & Recuento & 0 & 3 & 1 & 0 & 4 \\
\hline & $\begin{array}{l}\% \mathrm{n} .^{\mathrm{o}} \text { reacciones por } \\
\text { parte de los } \\
\text { seguidores }\end{array}$ & $0,0 \%$ & $75,0 \%$ & $25,0 \%$ & $0,0 \%$ & $100,0 \%$ \\
\hline & $\begin{array}{l}\% \text { de } n .^{\circ} \text { de comenta- } \\
\text { rios por parte de la } \\
\text { marca }\end{array}$ & $0,0 \%$ & $12,0 \%$ & $20,0 \%$ & $0,0 \%$ & $2,5 \%$ \\
\hline & $\%$ del total & $0,0 \%$ & $1,8 \%$ & $0,6 \%$ & $0,0 \%$ & $2,5 \%$ \\
\hline \multirow{4}{*}{$\begin{array}{l}\text { De } \\
5.000 \\
\text { a } 5.999\end{array}$} & Recuento & 1 & 1 & 0 & 0 & 2 \\
\hline & $\begin{array}{l}\% \mathrm{n} .^{\mathrm{o}} \text { reacciones por } \\
\text { parte de los } \\
\text { seguidores }\end{array}$ & $50,0 \%$ & $50,0 \%$ & $0,0 \%$ & $0,0 \%$ & $100,0 \%$ \\
\hline & $\begin{array}{l}\% \text { de } .^{\circ} \text { de comenta- } \\
\text { rios por parte de la } \\
\text { marca }\end{array}$ & $0,8 \%$ & $4,0 \%$ & $0,0 \%$ & $0,0 \%$ & $1,2 \%$ \\
\hline & $\%$ del total & $0,6 \%$ & $0,6 \%$ & $0,0 \%$ & $0,0 \%$ & $1,2 \%$ \\
\hline \multirow{4}{*}{$\begin{array}{l}\text { De } \\
6.000 \\
\text { a } 6.999\end{array}$} & Recuento & 1 & 0 & 0 & 0 & 1 \\
\hline & $\begin{array}{l}\% \mathrm{n} .^{\mathrm{o}} \text { reacciones por } \\
\text { parte de los } \\
\text { seguidores }\end{array}$ & $100,0 \%$ & $0,0 \%$ & $0,0 \%$ & $0,0 \%$ & $100,0 \%$ \\
\hline & $\begin{array}{l}\% \text { de } n^{\circ} \text { de comenta- } \\
\text { rios por parte de la } \\
\text { marca }\end{array}$ & $0,8 \%$ & $0,0 \%$ & $0,0 \%$ & $0,0 \%$ & $0,6 \%$ \\
\hline & $\%$ del total & $0,6 \%$ & $0,0 \%$ & $0,0 \%$ & $0,0 \%$ & $0,6 \%$ \\
\hline
\end{tabular}




\begin{tabular}{|c|c|c|c|c|c|c|}
\hline \multirow{2}{*}{\multicolumn{2}{|c|}{$\begin{array}{l}\text { Número de reacciones por } \\
\text { parte de los seguidores }\end{array}$}} & \multicolumn{5}{|c|}{ Número de comentarios por parte de la marca } \\
\hline & & $\begin{array}{c}\text { Sin } \\
\text { comentarios }\end{array}$ & Una & Tres & Cuatro & Total \\
\hline \multirow{4}{*}{$\begin{array}{l}\text { De } \\
8.000 \\
\text { a } 8.999\end{array}$} & Recuento & 2 & 5 & 0 & 0 & 7 \\
\hline & $\begin{array}{l}\% \text { n. } .^{\circ} \text { reacciones por } \\
\text { parte de los } \\
\text { seguidores }\end{array}$ & $28,6 \%$ & $71,4 \%$ & $0,0 \%$ & $0,0 \%$ & $100,0 \%$ \\
\hline & $\begin{array}{l}\% \text { de } n .^{\circ} \text { de comenta- } \\
\text { rios por parte de la } \\
\text { marca }\end{array}$ & $1,6 \%$ & $20,0 \%$ & $0,0 \%$ & $0,0 \%$ & $4,3 \%$ \\
\hline & $\%$ del total & $1,2 \%$ & $3,1 \%$ & $0,0 \%$ & $0,0 \%$ & $4,3 \%$ \\
\hline \multirow{4}{*}{$\begin{array}{l}10.000 \\
\text { o más }\end{array}$} & Recuento & 5 & 0 & 3 & 0 & 8 \\
\hline & $\begin{array}{l}\% \mathrm{n} .^{\circ} \text { reacciones por } \\
\text { parte de los } \\
\text { seguidores }\end{array}$ & $62,5 \%$ & $0,0 \%$ & $37,5 \%$ & $0,0 \%$ & $100,0 \%$ \\
\hline & $\begin{array}{l}\% \text { de }{ }^{\circ} .^{\circ} \text { de comenta- } \\
\text { rios por parte de la } \\
\text { marca }\end{array}$ & $4,0 \%$ & $0,0 \%$ & $60,0 \%$ & $0,0 \%$ & $4,9 \%$ \\
\hline & $\%$ del total & $3,1 \%$ & $0,0 \%$ & $1,8 \%$ & $0,0 \%$ & $4,9 \%$ \\
\hline \multirow{4}{*}{ Total } & Recuento & 125 & 25 & 5 & 8 & 163 \\
\hline & $\begin{array}{l}\% \mathrm{n} .^{\circ} \text { reacciones por } \\
\text { parte de los } \\
\text { seguidores }\end{array}$ & $76,7 \%$ & $15,3 \%$ & $3,1 \%$ & $4,9 \%$ & $100,0 \%$ \\
\hline & $\begin{array}{l}\% \text { de } n .{ }^{\circ} \text { de comenta- } \\
\text { rios por parte de la } \\
\text { marca }\end{array}$ & $100,0 \%$ & $100,0 \%$ & $100,0 \%$ & $100,0 \%$ & $100,0 \%$ \\
\hline & $\%$ del total & $76,7 \%$ & $15,3 \%$ & $3,1 \%$ & $4,9 \%$ & $100,0 \%$ \\
\hline
\end{tabular}


Tabla 4. Número de comentarios por parte de la marca en función del número de veces que el contenido fue compartido por los seguidores

\begin{tabular}{|c|c|c|c|c|c|c|}
\hline \multirow{2}{*}{\multicolumn{2}{|c|}{$\begin{array}{l}\text { Número de veces que el } \\
\text { contenido fue compartido } \\
\text { por los seguidores }\end{array}$}} & \multicolumn{5}{|c|}{ Número de comentarios por parte de la marca } \\
\hline & & $\begin{array}{c}\text { Sin } \\
\text { comentarios }\end{array}$ & Una & Tres & Cuatro & Total \\
\hline \multirow{4}{*}{$\begin{array}{l}\text { Sin } \\
\text { compar- } \\
\text { tir }\end{array}$} & Recuento & 7 & 0 & 0 & 0 & 7 \\
\hline & $\begin{array}{l}\% \text { de } n .^{\circ} \text { veces } \\
\text { compartido }\end{array}$ & $100,0 \%$ & $0,0 \%$ & $0,0 \%$ & $0,0 \%$ & $100,0 \%$ \\
\hline & $\begin{array}{l}\% \text { de } n .^{\circ} \text { de } \\
\text { comentarios por } \\
\text { parte de la marca }\end{array}$ & $5,6 \%$ & $0,0 \%$ & $0,0 \%$ & $0,0 \%$ & $4,3 \%$ \\
\hline & $\%$ del total & $4,3 \%$ & $0,0 \%$ & $0,0 \%$ & $0,0 \%$ & $4,3 \%$ \\
\hline \multirow{4}{*}{$\begin{array}{l}\text { De } 1 \\
\text { a } 99\end{array}$} & Recuento & 82 & 8 & 0 & 0 & 90 \\
\hline & $\begin{array}{l}\% \text { de } n .^{\circ} \text { veces } \\
\text { compartido }\end{array}$ & $91,1 \%$ & $8,9 \%$ & $0,0 \%$ & $0,0 \%$ & $100,0 \%$ \\
\hline & $\begin{array}{l}\% \text { de } n .^{\circ} \text { de } \\
\text { comentarios por } \\
\text { parte de la marca }\end{array}$ & $65,6 \%$ & $32,0 \%$ & $0,0 \%$ & $0,0 \%$ & $55,2 \%$ \\
\hline & $\%$ del total & $50,3 \%$ & $4,9 \%$ & $0,0 \%$ & $0,0 \%$ & $55,2 \%$ \\
\hline \multirow{4}{*}{$\begin{array}{l}\text { De } 100 \\
\text { a } 199\end{array}$} & Recuento & 15 & 8 & 0 & 0 & 23 \\
\hline & $\begin{array}{l}\% \text { de } .^{\circ} \text { veces } \\
\text { compartido }\end{array}$ & $65,2 \%$ & $34,8 \%$ & $0,0 \%$ & $0,0 \%$ & $100,0 \%$ \\
\hline & $\begin{array}{l}\% \text { de } n .^{\circ} \text { de } \\
\text { comentarios por } \\
\text { parte de la marca }\end{array}$ & $12,0 \%$ & $32,0 \%$ & $0,0 \%$ & $0,0 \%$ & $14,1 \%$ \\
\hline & $\%$ del total & $9,2 \%$ & $4,9 \%$ & $0,0 \%$ & $0,0 \%$ & $14,1 \%$ \\
\hline
\end{tabular}




\begin{tabular}{|c|c|c|c|c|c|c|}
\hline \multirow{2}{*}{\multicolumn{2}{|c|}{$\begin{array}{c}\text { Número de veces que el } \\
\text { contenido fue compartido } \\
\text { por los seguidores }\end{array}$}} & \multicolumn{5}{|c|}{ Número de comentarios por parte de la marca } \\
\hline & & $\begin{array}{c}\text { Sin } \\
\text { comentarios }\end{array}$ & Una & Tres & Cuatro & Total \\
\hline \multirow{4}{*}{$\begin{array}{l}\text { De } 200 \\
\text { a } 299\end{array}$} & Recuento & 11 & 4 & 1 & 8 & 24 \\
\hline & $\begin{array}{l}\% \text { de } n .^{\circ} \text { veces } \\
\text { compartido }\end{array}$ & $45,8 \%$ & $16,7 \%$ & $4,2 \%$ & $33,3 \%$ & $100,0 \%$ \\
\hline & $\begin{array}{l}\% \text { de } n .^{\circ} \text { de } \\
\text { comentarios por } \\
\text { parte de la marca }\end{array}$ & $8,8 \%$ & $16,0 \%$ & $20,0 \%$ & $100,0 \%$ & $14,7 \%$ \\
\hline & $\%$ del total & $6,7 \%$ & $2,5 \%$ & $0,6 \%$ & $4,9 \%$ & $14,7 \%$ \\
\hline \multirow{4}{*}{$\begin{array}{l}\text { De } 300 \\
\text { a } 399\end{array}$} & Recuento & 6 & 5 & 0 & 0 & 11 \\
\hline & $\begin{array}{l}\% \text { de n. }{ }^{\circ} \text { veces } \\
\text { compartido }\end{array}$ & $54,5 \%$ & $45,5 \%$ & $0,0 \%$ & $0,0 \%$ & $100,0 \%$ \\
\hline & $\begin{array}{l}\% \text { de } n .^{o} \text { de } \\
\text { comentarios por } \\
\text { parte de la marca }\end{array}$ & $4,8 \%$ & $20,0 \%$ & $0,0 \%$ & $0,0 \%$ & $6,7 \%$ \\
\hline & $\%$ del total & $3,7 \%$ & $3,1 \%$ & $0,0 \%$ & $0,0 \%$ & $6,7 \%$ \\
\hline \multirow{4}{*}{$\begin{array}{l}\text { De } 400 \\
\text { a } 499\end{array}$} & Recuento & 2 & 0 & 1 & 0 & 3 \\
\hline & $\begin{array}{l}\% \text { de } n .^{o} \text { veces } \\
\text { compartido }\end{array}$ & $66,7 \%$ & $0,0 \%$ & $33,3 \%$ & $0,0 \%$ & $100,0 \%$ \\
\hline & $\begin{array}{l}\text { \% de }{ }^{\circ} .^{\text {de }} \\
\text { comentarios por } \\
\text { parte de la marca }\end{array}$ & $1,6 \%$ & $0,0 \%$ & $20,0 \%$ & $0,0 \%$ & $1,8 \%$ \\
\hline & $\%$ del total & $1,2 \%$ & $0,0 \%$ & $0,6 \%$ & $0,0 \%$ & $1,8 \%$ \\
\hline
\end{tabular}




\begin{tabular}{|c|c|c|c|c|c|c|}
\hline \multirow{2}{*}{\multicolumn{2}{|c|}{$\begin{array}{c}\text { Número de veces que el } \\
\text { contenido fue compartido } \\
\text { por los seguidores }\end{array}$}} & \multicolumn{5}{|c|}{ Número de comentarios por parte de la marca } \\
\hline & & $\begin{array}{c}\text { Sin } \\
\text { comentarios }\end{array}$ & Una & Tres & Cuatro & Total \\
\hline \multirow{4}{*}{$\begin{array}{l}\text { De } 600 \text { a } \\
699\end{array}$} & Recuento & 1 & 0 & 0 & 0 & 1 \\
\hline & $\begin{array}{l}\% \text { de } n .^{\circ} \text { veces } \\
\text { compartido }\end{array}$ & $100,0 \%$ & $0,0 \%$ & $0,0 \%$ & $0,0 \%$ & $100,0 \%$ \\
\hline & $\begin{array}{l}\% \text { de } n .^{\circ} \text { de } \\
\text { comentarios por } \\
\text { parte de la marca }\end{array}$ & $0,8 \%$ & $0,0 \%$ & $0,0 \%$ & $0,0 \%$ & $0,6 \%$ \\
\hline & $\%$ del total & $0,6 \%$ & $0,0 \%$ & $0,0 \%$ & $0,0 \%$ & $0,6 \%$ \\
\hline \multirow{4}{*}{$\begin{array}{l}\text { De } 700 \text { a } \\
799\end{array}$} & Recuento & 1 & 0 & 3 & 0 & 4 \\
\hline & $\begin{array}{l}\% \text { de }{ }^{\circ}{ }^{\circ} \text { veces } \\
\text { compartido }\end{array}$ & $25,0 \%$ & $0,0 \%$ & $75,0 \%$ & $0,0 \%$ & $100,0 \%$ \\
\hline & $\begin{array}{l}\% \text { de } n .^{\circ} \text { de } \\
\text { comentarios por } \\
\text { parte de la marca }\end{array}$ & $0,8 \%$ & $0,0 \%$ & $60,0 \%$ & $0,0 \%$ & $2,5 \%$ \\
\hline & $\%$ del total & $0,6 \%$ & $0,0 \%$ & $1,8 \%$ & $0,0 \%$ & $2,5 \%$ \\
\hline \multirow{4}{*}{ Total } & Recuento & 125 & 25 & 5 & 8 & 163 \\
\hline & $\begin{array}{l}\% \text { de }{ }^{\circ}{ }^{\circ} \text { veces } \\
\text { compartido }\end{array}$ & $76,7 \%$ & $15,3 \%$ & $3,1 \%$ & $4,9 \%$ & $100,0 \%$ \\
\hline & $\begin{array}{l}\text { \% de } n .^{o} \text { de } \\
\text { comentarios por } \\
\text { parte de la marca }\end{array}$ & $100,0 \%$ & $100,0 \%$ & $100,0 \%$ & $100,0 \%$ & $100,0 \%$ \\
\hline & $\%$ del total & $76,7 \%$ & $15,3 \%$ & $3,1 \%$ & $4,9 \%$ & $100,0 \%$ \\
\hline
\end{tabular}


Tabla 5. Número de comentarios por parte de la marca en función del número de comentarios efectuados por parte de los seguidores

\begin{tabular}{|c|c|c|c|c|c|c|}
\hline \multirow{2}{*}{\multicolumn{2}{|c|}{$\begin{array}{c}\text { Número de comentarios por } \\
\text { parte de los seguidores }\end{array}$}} & \multicolumn{5}{|c|}{ Número de comentarios por parte de la marca } \\
\hline & & $\begin{array}{c}\text { Sin } \\
\text { comentarios }\end{array}$ & Una & Tres & Cuatro & Total \\
\hline \multirow{4}{*}{$\begin{array}{l}\text { Sin } \\
\text { compar- } \\
\text { tir }\end{array}$} & Recuento & 12 & 0 & 0 & 0 & 12 \\
\hline & $\begin{array}{l}\% \text { de }{ }^{\circ}{ }^{\circ} \text { comenta- } \\
\text { rios por parte de } \\
\text { los seguidores }\end{array}$ & $100,0 \%$ & $0,0 \%$ & $0,0 \%$ & $0,0 \%$ & $100,0 \%$ \\
\hline & $\begin{array}{l}\% \text { de } n .{ }^{\circ} \text { de comen- } \\
\text { tarios por parte de } \\
\text { la marca }\end{array}$ & $9,6 \%$ & $0,0 \%$ & $0,0 \%$ & $0,0 \%$ & $7,4 \%$ \\
\hline & $\%$ del total & $7,4 \%$ & $0,0 \%$ & $0,0 \%$ & $0,0 \%$ & $7,4 \%$ \\
\hline \multirow{4}{*}{$\begin{array}{l}\text { De } 1 \\
\text { a } 99\end{array}$} & Recuento & 108 & 20 & 1 & 8 & 137 \\
\hline & $\begin{array}{l}\% \text { de }{ }^{\circ}{ }^{\circ} \text { comenta- } \\
\text { rios por parte de } \\
\text { los seguidores }\end{array}$ & $78,8 \%$ & $14,6 \%$ & $0,7 \%$ & $5,8 \%$ & $100,0 \%$ \\
\hline & $\begin{array}{l}\% \text { de } n .{ }^{\circ} \text { de comen- } \\
\text { tarios por parte de } \\
\text { la marca }\end{array}$ & $86,4 \%$ & $80,0 \%$ & $20,0 \%$ & $100,0 \%$ & $84,0 \%$ \\
\hline & $\%$ del total & $66,3 \%$ & $12,3 \%$ & $0,6 \%$ & $4,9 \%$ & $84,0 \%$ \\
\hline \multirow{4}{*}{$\begin{array}{l}\text { De } 100 \\
\text { a } 199\end{array}$} & Recuento & 3 & 0 & 1 & 0 & 4 \\
\hline & $\begin{array}{l}\% \text { de }{ }^{\circ}{ }^{\circ} \text { comenta- } \\
\text { rios por parte de } \\
\text { los seguidores }\end{array}$ & $75,0 \%$ & $0,0 \%$ & $25,0 \%$ & $0,0 \%$ & $100,0 \%$ \\
\hline & $\begin{array}{l}\% \text { de } n .{ }^{\circ} \text { de comen- } \\
\text { tarios por parte de } \\
\text { la marca }\end{array}$ & $2,4 \%$ & $0,0 \%$ & $20,0 \%$ & $0,0 \%$ & $2,5 \%$ \\
\hline & $\%$ del total & $1,8 \%$ & $0,0 \%$ & $0,6 \%$ & $0,0 \%$ & $2,5 \%$ \\
\hline
\end{tabular}




\begin{tabular}{|c|c|c|c|c|c|c|}
\hline \multirow{2}{*}{\multicolumn{2}{|c|}{$\begin{array}{l}\text { Número de comentarios por } \\
\text { parte de los seguidores }\end{array}$}} & \multicolumn{5}{|c|}{ Número de comentarios por parte de la marca } \\
\hline & & $\begin{array}{c}\text { Sin } \\
\text { comentarios }\end{array}$ & Una & Tres & Cuatro & Total \\
\hline \multirow{4}{*}{$\begin{array}{l}\text { De } 200 \\
\text { a } 299\end{array}$} & Recuento & 1 & 0 & 3 & 0 & 4 \\
\hline & $\begin{array}{l}\% \text { de } .^{\circ} \text { comenta- } \\
\text { rios por parte de } \\
\text { los seguidores }\end{array}$ & $25,0 \%$ & $0,0 \%$ & $75,0 \%$ & $0,0 \%$ & $100,0 \%$ \\
\hline & $\begin{array}{l}\% \text { de } n .^{\circ} \text { de comen- } \\
\text { tarios por parte de } \\
\text { la marca }\end{array}$ & $0,8 \%$ & $0,0 \%$ & $60,0 \%$ & $0,0 \%$ & $2,5 \%$ \\
\hline & $\%$ del total & $0,6 \%$ & $0,0 \%$ & $1,8 \%$ & $0,0 \%$ & $2,5 \%$ \\
\hline \multirow{4}{*}{$\begin{array}{l}\text { De } 300 \\
\text { a } 399\end{array}$} & Recuento & 0 & 5 & 0 & 0 & 5 \\
\hline & $\begin{array}{l}\% \text { de } n .^{\circ} \text { comenta- } \\
\text { rios por parte de } \\
\text { los seguidores }\end{array}$ & $0,0 \%$ & $100,0 \%$ & $0,0 \%$ & $0,0 \%$ & $100,0 \%$ \\
\hline & $\begin{array}{l}\% \text { de } .^{\circ} \text { de comen- } \\
\text { tarios por parte de } \\
\text { la marca }\end{array}$ & $0,0 \%$ & $20,0 \%$ & $0,0 \%$ & $0,0 \%$ & $3,1 \%$ \\
\hline & $\%$ del total & $0,0 \%$ & $3,1 \%$ & $0,0 \%$ & $0,0 \%$ & $3,1 \%$ \\
\hline \multirow{4}{*}{$\begin{array}{l}1.000 \\
\text { o más }\end{array}$} & Recuento & 1 & 0 & 0 & 0 & 1 \\
\hline & $\begin{array}{l}\% \text { de }{ }^{\circ}{ }^{\circ} \text { comenta- } \\
\text { rios por parte de } \\
\text { los seguidores }\end{array}$ & $100,0 \%$ & $0,0 \%$ & $0,0 \%$ & $0,0 \%$ & $100,0 \%$ \\
\hline & $\begin{array}{l}\% \text { de } .^{\circ} \text { de comen- } \\
\text { tarios por parte de } \\
\text { la marca }\end{array}$ & $0,8 \%$ & $0,0 \%$ & $0,0 \%$ & $0,0 \%$ & $0,6 \%$ \\
\hline & $\%$ del total & $0,6 \%$ & $0,0 \%$ & $0,0 \%$ & $0,0 \%$ & $0,6 \%$ \\
\hline
\end{tabular}




\begin{tabular}{|c|c|c|c|c|c|c|}
\hline \multirow{2}{*}{\multicolumn{2}{|c|}{$\begin{array}{c}\text { Número de comentarios por } \\
\text { parte de los seguidores }\end{array}$}} & \multicolumn{5}{|c|}{ Número de comentarios por parte de la marca } \\
\hline & & $\begin{array}{c}\text { Sin } \\
\text { comentarios }\end{array}$ & Una & Tres & Cuatro & Total \\
\hline \multirow{4}{*}{ Total } & Recuento & 125 & 25 & 5 & 8 & 163 \\
\hline & $\begin{array}{l}\% \text { de } .^{\circ} \text { comenta- } \\
\text { rios por parte de } \\
\text { los seguidores }\end{array}$ & $76,7 \%$ & $15,3 \%$ & $3,1 \%$ & $4,9 \%$ & $100,0 \%$ \\
\hline & $\begin{array}{l}\% \text { de } .^{\circ} \text { de comen- } \\
\text { tarios por parte de } \\
\text { la marca }\end{array}$ & $100,0 \%$ & $100,0 \%$ & $100,0 \%$ & $100,0 \%$ & $100,0 \%$ \\
\hline & $\%$ del total & $76,7 \%$ & $15,3 \%$ & $3,1 \%$ & $4,9 \%$ & $100,0 \%$ \\
\hline
\end{tabular}

La tabla 6, que muestra las correlaciones bivariadas, establece que suelen existir relaciones estadísticamente significativas entre el número de interacciones de los usuarios y el número de comentarios efectuados por la marca. De esta forma, las tres correlaciones que se producen son positivas, es decir, a medida que se incrementa la puntuación de una variable aumenta también en la otra. Por tanto, se puede afirmar que a mayor número de reacciones, de comentarios por parte de los usuarios y de contenido compartido, más respuestas por parte de la marca. 
Tabla 6. Relación existente entre el número de reacciones, de comentarios por parte de los seguidores y de contenido compartido frente al número de comentarios realizados por parte de la marca

Número de reacciones y número de comentarios por parte de la marca

\begin{tabular}{|c|c|c|c|}
\hline & & $\begin{array}{l}\text { Número de reacciones } \\
\text { por parte de los } \\
\text { usuarios }\end{array}$ & $\begin{array}{c}\text { Número de } \\
\text { comentarios por } \\
\text { parte de la marca }\end{array}$ \\
\hline \multirow{3}{*}{$\begin{array}{l}\text { Número de } \\
\text { reacciones por } \\
\text { parte de los } \\
\text { usuarios }\end{array}$} & $\begin{array}{l}\text { Correlación de } \\
\text { Pearson }\end{array}$ & 1 & $0,451^{* *}$ \\
\hline & Sig. (bilateral) & & 0,000 \\
\hline & $\mathrm{N}$ & 163 & 163 \\
\hline \multirow{3}{*}{$\begin{array}{l}\text { Número de } \\
\text { comentarios por } \\
\text { parte de la } \\
\text { marca }\end{array}$} & $\begin{array}{l}\text { Correlación de } \\
\text { Pearson }\end{array}$ & $0,451^{* *}$ & 1 \\
\hline & Sig. (bilateral) & 0,000 & \\
\hline & $\mathrm{N}$ & 163 & 163 \\
\hline \multicolumn{4}{|c|}{ Número de veces compartido y número de comentarios por parte de la marca } \\
\hline & & $\begin{array}{l}\text { Número de veces } \\
\text { compartido }\end{array}$ & $\begin{array}{c}\text { Número de } \\
\text { comentarios por } \\
\text { parte de la marca }\end{array}$ \\
\hline \multirow{3}{*}{$\begin{array}{l}\text { Número de veces } \\
\text { compartido }\end{array}$} & $\begin{array}{l}\text { Correlación de } \\
\text { Pearson }\end{array}$ & 1 & $0,451^{* *}$ \\
\hline & Sig. (bilateral) & & 0,000 \\
\hline & $\mathrm{N}$ & 163 & 163 \\
\hline \multirow{3}{*}{$\begin{array}{l}\text { Número de } \\
\text { comentarios por } \\
\text { parte de la } \\
\text { marca }\end{array}$} & $\begin{array}{l}\text { Correlación de } \\
\text { Pearson }\end{array}$ & $0,451^{* *}$ & 1 \\
\hline & Sig. (bilateral) & 0,000 & \\
\hline & $\mathrm{N}$ & 163 & 163 \\
\hline
\end{tabular}


Número de comentarios por parte de los seguidores y número de comentarios por parte de la marca

\begin{tabular}{llcc}
\hline & \multicolumn{1}{c}{$\begin{array}{c}\text { Número de } \\
\text { comentarios por parte } \\
\text { de los seguidores }\end{array}$} & $\begin{array}{c}\text { Número de } \\
\text { comentarios por } \\
\text { parte de la marca }\end{array}$ \\
\hline $\begin{array}{l}\text { Número de } \\
\text { comentarios por } \\
\text { parte de los } \\
\text { seguidores }\end{array}$ & $\begin{array}{l}\text { Correlación de } \\
\text { Pearson }\end{array}$ & 1 & $0,167^{*}$ \\
\cline { 2 - 4 } & Sig. (bilateral) & & 0,033 \\
\hline $\begin{array}{l}\text { Número de } \\
\text { comentarios por } \\
\text { parte de la } \\
\text { marca }\end{array}$ & $\begin{array}{l}\text { Correlación de } \\
\text { Pearson }\end{array}$ & 163 & 163 \\
\cline { 2 - 4 } & Sig. (bilateral) & $0,167^{*}$ & 1 \\
\hline
\end{tabular}

* La correlación es significativa en el nivel 0,05 (bilateral).

** La correlación es significativa en el nivel 0,01 (bilateral).

\section{CONCLUSIONES}

Para concluir, cabe destacar que es habitual que los seguidores de Hugo Boss interactúen con los posts que realiza la marca en Facebook, pues suelen utilizar los botones de reacción, acostumbran a compartir el contenido y lo comentan frecuentemente. Así, podría considerarse que el nivel de compromiso que conllevan las reacciones es básico, pues incluir comentarios conlleva mayor grado de implicación y de dedicación, ya que el usuario se involucra con la publicación, aporta su opinión y se responsabiliza de ella (Merino Bobillo, Lloves Sobrado y Pérez Guerrero 2013). Aún así, la opción de compartir contenido es la que genera mayor grado de implicación, pues el usuario incluye el post en su propio perfil (Merino Bobillo, Lloves Sobrado y Pérez Guerrero 2013). Por tanto, y debido a que los seguidores de Hugo Boss suelen utilizar estos tres tipos 
de interacción, se podría afirmar que los usuarios poseen una gran implicación con la marca.

A pesar de estos datos, la organización no suele responder a los comentarios de sus seguidores con asiduidad, de hecho, Hugo Boss suele dialogar con sus seguidores principalmente en aquellos posts que poseen una mayor repercusión. Esta situación concuerda con la obtenida en anteriores investigaciones, ya que las marcas de moda no suelen volver a interactuar con sus usuarios mediante comentarios a raíz de un tuit (Navarro Beltrá, Miquel Segarra y García Medina 2017). De esta forma, se podría afirmar que, a pesar de que las redes sociales se han convertido en una herramienta imprescindible para las empresas (Guirado 2012), parece que el sector de la moda en general, y Hugo Boss en particular, no está interactuando suficientemente con sus seguidores y, por tanto, no se está aprovechando totalmente la interactividad que ofrecen las redes sociales.

La principal limitación de este trabajo se basa en haber analizado únicamente una red social, Facebook, pues la marca podría estar participando y obteniendo una repercusión diferente en otras plataformas. Por tanto, surge una línea de investigación que se centra en analizar y comparar las interacciones y las repercusiones que Hubo Boss obtiene en diferentes redes sociales, como por ejemplo Instagram.

\section{BIBLIOGRAFÍA}

Aced, Cristina. 2010. Perfiles profesionales 2.0. Barcelona: Editorial UOC. —. 2013. Relaciones públicas 2.0: cómo gestionar la comunicación corporativa en el entorno digital. Barcelona: Editorial UOC.

Alonso, Marián. 2015. «Las redes sociales como canal de comunicación de las marcas de moda españolas. El caso de Zara, Mango y El Corte Inglés». Index Comunicación: Revista Científica de Comunicación Aplicada, 1 (5): 77-105. Madrid: Departamento de Ciencias de la Comunicación y Sociología, Facultad de Comunicación, Universidad Rey Juan Carlos. 
Asociación para la Investigación de Medios de Comunicación (AIMC). 2018. 20. ${ }^{\circ}$ Navegantes en la red. Encuesta aimc a usuarios de internet. Marzo 2018. Madrid: Asociación para la Investigación de Medios de Comunicación (AIMC). http://cort.as/-EADr

Castelló, Araceli. 2010. «La sensibilización medioambiental en redes sociales online». FISEC-Estrategias, año V, 13: 23-47. Buenos Aires: Facultad de Ciencias Sociales, Universidad Nacional de Lomas de Zamora.

Cheung, Fanny Sau-Lan y Wing-Fail Leung. 2016. «Facebook Users' Habits in Getting Commercial Information: A Study on Hong Kong Students». Economics, Management, and Financial Markets, 11 (3): 56-71. Nueva York: Addleton Academic Publishers.

Colombo, Daniel y Felicitas Castrillón. 2010. «Comunicación de marcas de lujo. El deseo de generar deseo». The Journal of PR, 1 (1): 61-86. Buenos Aires: Consejo Profesional de Relaciones Públicas de la República Argentina.

Del Fresno, Miguel. 2012. «Comprendiendo los social media y mass media: un modelo para el estudio de la comunicación interpersonal colectiva en tiempos de internet». Derecom: Revista Internacional Online de Derecho de la Comunicación, 11: 99-109. Madrid: Sección Departamental de Derecho Constitucional, Facultad de Ciencias de la Información, Universidad Complutense de Madrid (UCM).

Del Pino Romero, Cristina y Araceli Castelló Martínez. 2015. «La comunicación publicitaria se pone de moda: branded content y fashion films». Revista Mediterránea de Comunicación, 6 (1): 105-128. Alicante: Grupo de investigación Comunicación y Públicos Específicos, Universidad de Alicante. DOI: 10.14198/MEDCOM2015.6.1.07

Domingo, Gemma. 2013. «Las marcas de moda en un contexto digital: retos y oportunidades». Actas del Primer Congreso Internacional Comunicación y Sociedad. Logroño: UNIR. http://cort.as/-EADz

Escandell, Raquel y Mar Iglesias. 2014. «Los soportes publicitarios online y la publicidad en los medios sociales». En Claves en la planificación de la publicidad online: fundamentos, herramientas y retos, coord. N. Papí. Madrid: Asociación para la Investigación de Medios de Comunicación (AIMC). 
Fondevila, Joan Francesc, Josep Lluís Del Olmo y Vanesa Bravo. 2012. «Presencia y reputación digital en social media: comparativa en el sector de la moda». Fonseca, Journal of Communication, 5: 92-116. Salamanca: Universidad de Salamanca.

García Medina, Irene, Susana Miquel Segarra y Marián Navarro Beltrá. 2018. «El uso de Twitter en las marcas de moda. Marcas de lujo frente a marcas low-cost». Cuadernos.info, 42: 55-70. Santiago de Chile: Facultad de Comunicaciones, Pontificia Universidad Católica de Chile. DOI: 10.7764/cdi.42.1349

Guirado, María Remedios. 2012. «La interacción de los públicos en Facebook. El caso de los periódicos en Andalucía». Revista Internacional de Relaciones Públicas, 2 (3): 27-44. Málaga: Instituto de Investigación en Relaciones Públicas, Universidad de Málaga. DOI: 10.5783/RIRP-3-2012-02-27-44

Interactive Advertising Bureau (IAB). 2009. El libro blanco de IAB. La comunicación en medios sociales 8. Madrid: Edipo.

Interactive Advertising Boureau (IAB). 2018. Estudio anual de redes sociales 2018. http://cort.as/-EAE1

Merino-Bobillo, María, Beatriz Lloves Sobrado y Ana María Pérez Guerrero. 2013. «La interacción de los usuarios en los perfiles de Facebook de la prensa española». Palabra Clave, 16 (3): 842-872. Chía, Colombia: Facultad de Comunicación Social y Periodismo, Universidad de La Sabana.

Navarro Beltrá, Marián, Susana Miquel Segarra y Irene García Medina. 2017. «El uso del potencial dialógico de Twitter: el caso de las marcas de moda». Ámbitos: Revista Internacional de Comunicación, 36. Sevilla: Grupo de Investigación en Estructura, Historia y Contenidos de la Comunicación (GREHCCO), Universidad de Sevilla. http://cort. as/-EAE7

Orbea, Jesús, Mar Iglesias y Natalia Papí. 2014. «La publicidad online». En Claves en la planificación de la publicidad online: fundamentos, herramientas y retos, coord. N. Papí. Madrid: Asociación para la Investigación de Medios de Comunicación (AIMC). 
Roca, Meritxell. 2014. «La transformación de la industria publicitaria en la era digital. Percepciones de los profesionales en Estados Unidos: retos y oportunidades». Revista TELOS (Cuadernos de Comunicación e Innovación), 99: 64-74. Madrid: Fundación Telefónica.

Viadana, Claudia A., Alicia Isidoro, M. ${ }^{a}$ Lourdes Zubeldía, Verónica Rossi y Óscar Morales. 2011. «De la cultura 1.0 a la cultura 2.0. Análisis de un caso de aplicación de herramientas 2.0 a la comunicación interna. Decimosextas Jornadas «Investigaciones en la Facultad» de Ciencias Económicas y Estadística. Santa Fe, Argentina: Universidad Nacional de Rosario. http://cort.as/-EAEF 


\section{LA NARRATIVA TRANSMEDIA: EL CASO DE LEGO}

José Luis Roglá LACUEVA Universitat Jaume I

\section{Resumen}

En las últimas décadas se han producido una serie de cambios importantes en el sector del juguete, sobre todo debido a la influencia de las tecnologías digitales, como son los videojuegos, la robótica o los smartphones y tabletas. Esto unido a la creciente demanda del usuario de ser un sujeto activo en la creación del mensaje y no un mero espectador, ha obligado a las empresas de juguetes tradicionales a reinventarse. El presente artículo analiza el caso de LEGO, una empresa que lleva activa más de ochenta años y que se ha visto en numerosas ocasiones en la necesidad de cambiar su estrategia empresarial y su comunicación, orientándose en los últimos años hacia el storytelling transmedia, para hacer frente a los cambios en el sector.

Palabras clave: storytelling; transmedia; narrativa transmedia; LEGO; comunidad; marca.

\section{INTRODUCCIÓN}

\subsection{Propósito del trabajo}

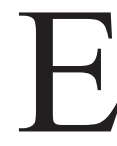

STE ARTÍ́CULO PRETENDE ANALIZAR LA DERIVA del sector hacia la narrativa transmedia, tomando como ejemplo la empresa de juguetes LEGO, una de las marcas que mejor ha estado implementando este nuevo tipo de narrativa, desde la creación de juguetes, pasando por sus propias películas, colaboraciones con franquicias como Star Wars, Harry Potter o Batman, juegos, aplicaciones e incluso sus propios parques de atracciones. 
El universo de LEGO ha convertido al consumidor en una parte integrante de la empresa y le ha permitido proyectar al mundo su visión de la marca de múltiples maneras diferentes, otorgándole así riqueza y profundidad. En este artículo se analizarán y explicarán los diferentes cambios que ha experimentado la empresa a lo largo de su historia y como esta ha utilizado el recurso del storytelling para no solo hacer frente a las amenazas del sector y sobrevivir, sino también para crecer como empresa y hacer aún más grande su marca.

Este caso es un indicador de la tendencia actual de un sector que cada vez es más cambiante y en el que los productos en si han pasado a un segundo plano y lo que de verdad importa es la relación y las historias que la marca y el usuario construyen juntos.

\subsection{La narrativa transmedia}

La narrativa transmedia o transmedia storytelling es un término introducido en el año 2003 por Henry Jenkins, catedrático de la Universidad del Sur de California, que trata de englobar un proceso que se ha producido en las últimas décadas, basado en la convergencia de lenguajes, formatos y medios en el ámbito de la comunicación.

Como apuntan Galán, Rodríguez Serrano y Marzal Felici (2018, 14) el transmedia se puede definir como «una manera de comunicar en la que cada medio cuenta una parte independiente y complementaria del relato». Cuando hablamos de relatos, estamos haciendo referencia a algo tan básico como es la acción de contar historias, que pueden ser más o menos complejas. En los relatos transmedia estas historias, por la propia naturaleza del concepto, se convierten en una especie de puzle o laberinto en el que el usuario puede intervenir en mayor o menor medida, dependiendo del grado de conocimiento que se quiera obtener del relato.

La narrativa transmedia se opone así al tradicional sistema de comunicación basado en la unidireccionalidad, sistema en el que el receptor tiene poca o ninguna capacidad de participación activa sobre el mensaje que está recibiendo. Por su parte, el receptor de la comunicación 
transmedia es entendido como una comunidad en la que los diferentes miembros comparten ciertos intereses que fomentan la creación de vínculos (Galán, Rodríguez Serrano y Marzal Felici 2018). Esta comunidad se caracteriza por tener el poder de cambiar el mensaje y crear uno completamente diferente, generando así bidireccionalidad para con el emisor. Este cambio de rol se ha producido, en gran medida, por la aparición de internet y especialmente de las redes sociales. Estas otorgan los recursos y el espacio que necesitan los usuarios, ahora convertidos en prosumidores, para dialogar e interactuar. De esta forma, comparten su opinión, intereses, preocupaciones y experiencias, generando contenido a lo largo del proceso.

El relato transmedia tiene en la mayoría de los casos un gran componente visual, esto es en parte el resultado de la tendencia apuntada por Kress y Van Leewn (1998) según la cual las comunicaciones han dejado de estructurarse tanto utilizando medios lingüísticos, especialmente escritos, y han pasado a hacerlo cada vez más por medios visuales. Es esta característica de nuestra sociedad actual lo que ha generado que la mayor parte de la infraestructura de medios y formatos construida en los últimos años, como pueden ser las redes sociales, haya sido enfocada hacia lo visual. Estos medios, aunque nuevos en cuanto a estructura y funcionamiento, en esencia utilizan los recursos típicos de los medios tradicionales pero, aprovechando las posibilidades que proporciona la tecnología actual, como es la interactividad, ofrecen una experiencia diferente (Campos Freire 2008).

La implementación de la narrativa transmedia, debido a la utilización de medios y formatos de muy diverso tipo, es un reto para las empresas cuyo sustento está basado en el sistema de comunicación tradicional y no están habituadas a la bidireccionalidad de este tipo de comunicación. Además, también supone un desafío para el ámbito de la investigación, ya que la amalgama de comunicaciones ha complicado en gran medida su estudio. Sin embargo, a pesar de las visibles dificultades, la narrativa transmedia ofrece un universo de posibilidades para la creación de comunidades y para hacer que el usuario tenga una mayor vinculación emocional con la marca. 
Este artículo parte de la hipótesis que la narrativa transmedia está en auge, ya que los usuarios han dejado de conformarse con ser simplemente sujetos pasivos del mensaje y ahora quieren formar parte de él. Asimismo, cabe añadir como segunda hipótesis que se dan algunos casos en los que la narrativa transmedia ha adquirido tal importancia en la comunicación de las empresas, como puede ser en el caso de LEGO, que ha pasado a formar una parte inherente de la misma e incluso define su propia identidad, misión y valores, ya que no se pueden entender sin el storytelling.

\section{OBJETIVOS}

Una vez expuestas las hipótesis sobre las que se sustenta esta investigación, debemos determinar los objetivos concretos que se pretenden conseguir a través de este artículo.

En primer lugar, partiendo de la primera hipótesis planteada, el objetivo general de esta investigación consiste en realizar una panorámica, a modo de análisis, sobre la comunicación de LEGO a lo largo de su extensa historia. Para ello destacaremos aquellas comunicaciones que puedan ser identificadas como transmedia, de modo que podamos observar de una forma cronológica en que momento (si lo hubo) la empresa empezó a utilizar en mayor medida la comunicación transmedia.

Además, también se pretende determinar la repercusión que el transmedia storytelling ha tenido para la empresa danesa en cuanto a ventas, estructura organizativa, producción, etc., concretando así hasta que punto la narrativa transmedia ha afectado a la estrategia empresarial global, en el caso de que esta se haya orientado o modificado hacia este tipo de comunicación basada en el storytelling.

En este sentido, para concretar aún más la tarea de investigación y aclarar las posibles ambigüedades de los objetivos, nos planteamos una serie de preguntas que se pretenden contestar a lo largo de este trabajo: ¿cómo la incorporación de elementos transmedia en la comunicación de LEGO ha influido en el conjunto de la organización?, ¿qué características 
diferenciadoras tiene LEGO que le permiten beneficiarse del transmedia?, ¿qué papel ha tenido el receptor o cliente en la estrategia llevada a cabo hasta el momento por parte de LEGO? y por último, ¿qué resultados ha proporcionado la aplicación de relatos transmedia en la comunicación de LEGO?

\section{METODOLOGÍA}

La metodología que se empleará es eminentemente de naturaleza cualitativa, ya que esencialmente se ha realizado un estudio descriptivo y analítico de la comunicación de la empresa en sus diversas formas. No obstante, también se han utilizado herramientas de tipo cuantitativo a la hora de determinar la repercusión de ciertas comunicaciones. Se ha optado por realizar la investigación haciendo uso de ambos métodos porque se consideran complementarios y porque se entiende que ayudan a contrastar y reforzar los análisis realizados.

Para ello la investigación se ha centrado en el estudio de la historia de la empresa, poniendo especial atención en las acciones estratégicas de organización y comunicación que contribuyeron a su imagen. Se analizará hasta qué punto dichas acciones tuvieron una influencia real en la percepción de los productos y de la marca, utilizando para ello encuestas realizadas por consultorías externas a ella.

Este artículo, además de dar una visión panorámica de las principales decisiones estratégicas que tuvo que realizar la empresa a lo largo de su larga historia, se centrará sobre todo en el análisis de las últimas décadas (a partir de los años ochenta) en las cuales la comunicación de LEGO experimentó un notable cambio. Se investigarán y analizarán las razones por las que la empresa lanzó determinados productos al mercado y por las que esta cambió su forma de comunicarse con el usuario, orientándose hacia el storytelling y como este se hizo de forma transmedia.

Los motivos que justifican la elección de este caso son en primer lugar la larga historia de la empresa, que nos permite observar como se ha ido adaptando a lo largo de las décadas a los cambios del sector, que 
tuvo su mayor periodo de transformación con la llegada de los videojuegos. Además, se trata de una compañía que se ha convertido en un icono económico y social y ha conseguido crear y mantener una comunidad de fans que se extiende a nivel global, los cuales no solo disfrutan del contenido de LEGO sino que lo crean y modifican, ampliando así las posibilidades de la empresa.

\section{RESULTADOS}

LEGO fue fundada por Ole Kirk Christiansen en el año 1932 en Dinamarca, el nombre de la cual proviene de la mezcla de las palabras danesas «jugar»y «bien» (leg godt) cosa que nos permite ver la propia identidad de la marca en su nombre.

La empresa comenzó su actividad fabricando juguetes de madera y a mediados de los años treinta, sus juguetes adquirieron una gran popularidad entre los niños. Uno de los más famosos fue un pato de madera atado a una cuerda, un tipo de juguete muy diferente a los que fabrican y por los que se le conocen en la actualidad. La popularidad de los juguetes y la mayor facilidad para obtener madera hizo que aumentara la producción de juguetes de este material con respecto a la de metal, el cual escaseaba, sobre todo durante los años de la Segunda Guerra Mundial, ya que iba destinado principalmente para la fabricación de armamento.

La gran demanda de juguetes de LEGO en la década de los cuarenta, unido a un incendio en la fábrica en el año 1942, hizo que empezase a escasear la madera para producir juguetes, por lo que optaron por un material nunca antes utilizado para la fabricación de este tipo de productos: el plástico. La empresa compró en 1946 su primera máquina de moldes por inyección y empezó a producir juguetes de todo tipo con este material: animales, pelotas, coches y los antecesores de los famosos bloques LEGO, aunque los bloques no se encajaban como en la actualidad. La empresa siguió produciendo juguetes de plástico y madera hasta que en 1958 se empezó a implementar un sistema de enganche mediante 
tubos debajo de los ladrillos de plástico (el mismo que utilizan en la actualidad) cosa que permitía encajar uno con otro y les proporcionaba una mayor estabilidad. Esta incorporación fue un éxito total entre el público, por lo que la empresa decidió centrarse únicamente en la producción de juguetes de plástico y discontinuó la producción de juguetes de madera.

La década de los sesenta consolidó a LEGO como empresa fabricante de juguetes en Europa. De hecho, la gran cantidad de fanáticos de la marca que iban a visitar las fábricas propició la creación del primer parque de atracciones de la compañía, llamado «Legoland», ubicado en la localidad de Billund, lugar de origen de la empresa. De esta forma se pretendía evitar tanta afluencia de gente en las fábricas.

En Estados Unidos la empresa tuvo que esperar hasta los años setenta para conseguir tener tanta relevancia como en Europa, debido a un desafortunado acuerdo con Samsonite que les impidió gestionar la empresa en el país hasta que se rescindió el contrato. Cuando esto sucedió, LEGO rápidamente adquirió una gran popularidad, pero en el 1981, cuando expiró la patente, empezaron a surgir por todos lados copias de su producto. Ante esta situación, la empresa tomó una decisión estratégica a modo de diferenciación de la competencia. Empezaron a fabricar sets de LEGo llamados LEGo Mindstorms que incluían tecnología robótica. Sin embargo, se encontraron con el problema que las personas que compraban estos sets no eran el público objetivo al cual iban dirigidos, es decir, niños y adolescentes, para utilizar en las aulas, sino que los estaban comprando adultos graduados en informática, los cuales empezaron a piratearlos y a hacer creaciones mucho más grandes e impresionantes que las que el producto básico ofrecía. La reacción de LEGO frente a esta situación fue demandar a los hackers, no obstante, pronto se dieron cuenta de que esta comunidad no solo no hacía daño a la empresa sino que le beneficiaba en gran medida, por lo que decidieron invertir en ello organizando competiciones de robots, introduciendo talleres para las escuelas, etc. Así pues, LEGO empezó a potenciar aún más su comunidad de fans, utilizando las nuevas tecnologías. Gracias a esto Lego consiguió salir del paso en la década de los ochenta, sin embargo, el sector del juguete 
cada vez se acercaba más a los videojuegos y en los años noventa LEGO volvió a sufrir una crisis.

Tras una serie de cambios estructurales en la empresa, la compañía de juguetes se adentró en el universo del transmedia a través de la creación del videojuego LEGO Island (1997). El juego seguía una mecánica de mundo abierto en el cual se podía merodear a lo largo y ancho de una isla, construyendo estructuras y vehículos. Además existía la posibilidad de cumplir varias misiones secundarias y una misión principal que consistía en atrapar a un criminal que había escapado de la prisión, no obstante esta misión solo se desbloqueaba si se construía el coche de policía. La mecánica del juego permitía a los jugadores crear sus propias historias ampliando así el (ahora transmedia) universo de LEGO. El videojuego fue un gran éxito, vendiendo más de 909.000 copias en Estados Unidos entre los años 1997 y 1999 (Dunnigan 2000) y propició la creación de una secuela lanzada en el 2001 titulada LEGO Island 2: The Brickster's Revenge.

\subsection{LEgo Star Wars}

En 1999 la empresa unió fuerzas con la popular saga de Star Wars y crearon el primer set de LEGO que combinó dos universos, el de LEGO y el de Star Wars, que por aquel entonces ya se había convertido en un caso ejemplar de universo transmedia. Esta colaboración, que continúa hasta la fecha, ha conseguido producir más de seiscientos sets de LEGO -muy valorados entre los niños y los coleccionistas-, videojuegos, cortos animados y series de televisión.

La forma en la que consiguieron unir ambos universos fue combinando la historia de las películas de Star Wars con la estética de LEGO. Esto marcó la estrategia de la empresa para futuras colaboraciones como LEGo Indiana Jones, LEgo Harry Potter o LEgo Batman, entre otros. Con los cuales también se han hecho y se siguen haciendo numerosos sets, videojuegos y animaciones. Como se publicó en una noticia de The New York Times en 2009, el éxito de estas alianzas, en especial la de Star Wars 
e Indiana Jones, consiguió hacer que la empresa pasase de estar al borde de la quiebra en 1999 a tener un aumento en las ventas estadounidenses de un $32 \%$ en 2005.

Star Wars es una franquicia que fue introducida por primera vez al público en el formato de largometraje con Star Wars: Episodio IV en 1977. No obstante, para cuando se produjo la colaboración con LEGO, la franquicia de Star Wars ya había estado llevando a cabo durante varios años una estrategia transmedia, mediante la creación de cientos de libros, cómics, videojuegos, series de televisión, además de figuras y juguetes oficiales de la saga. Todos estos diferentes medios contribuyeron a ampliar el complejo universo de Star Wars, atrayendo así a una variedad muy distinta de usuarios, los cuales tenían la posibilidad de entrar en la historia de diversas formas. Con esto se consigue aumentar la vinculación con el consumidor, ya que son los propios usuarios los que controlan hasta que punto quieren explorar la historia, convirtiéndose así en sujetos activos.

Así pues, con LEGO Star Wars, la franquicia de películas consiguió expandir aún más su universo y LEGO pudo ampliar sus horizontes abriéndose a un nuevo mercado en el que no se limitó únicamente a la creación de juguetes de la saga sino que se han estado creando series, películas e incluso videojuegos.

\subsection{LEGO Bionicle}

En 2001, LEGO tomó una acción estratégica que le acercó definitivamente al siglo XXI, creando la colección LEGo Bionicle. Esta colección iba dirigida a niños que disfrutaban más del aspecto de rol de jugar con LEGO y no tanto del proceso de construcción. Se trata de una colección que obtuvo un gran éxito durante varios años seguidos y que se caracteriza por haber sido planificada desde el inicio para ser lanzada utilizando una estrategia transmedia (Fonnesbaek y Melbye Andersen 2005).

Con esta colección la empresa dotó a los juguetes de una historia, cosa que aumentó el vínculo emocional con aquellos, generando una mayor implicación por parte del público objetivo. 
LEGO y la agencia de publicidad danesa Advance se unieron para crear una historia épica, que tenía lugar en un universo fantástico y en la que los juguetes de LEGO se convirtieron en los protagonistas principales. Para esta nueva colección, la empresa se marcó una serie de objetivos que se debían conseguir con la estrategia que se plantease, entre estos, se debía crear una historia alrededor de los personajes de LEGO Bionicle que atrajese al público objetivo, es decir, niños de entre 7 y 12 años. Además, cabe destacar que con Bionicle se tenía que añadir valor emocional a la marca, con una perspectiva a largo plazo, para potenciar así la creación de una base de fans de la que se pudiese sacar partido en otras áreas de negocio, como es el caso de Legoland (Fonnesbaek, Melbye Andersen 2005).

El principal reto que se encontraron desde LEGO fue que, a diferencia de las anteriores colecciones que habían producido, como LEGo City o incluso las colaboraciones como LEGo Star Wars, LEGo Bionicle no contaba con un universo previo que le diera soporte y en el que se pudiesen apoyar para anunciar los sets. Por el contrario, con LEGo Bionicle tuvieron que contar una historia que nadie conocía desde el principio, por lo que tuvieron que desarrollarla de una forma muy detallada para que resultase creíble para los niños y niñas. Así pues, LEGO y Advance desarrollaron una campaña de comunicación integral con el objetivo de transmitir la historia de una forma atractiva y cautivadora. La manera como plantearon esta estrategia se inspiró en la forma como se estructuran las campañas para promocionar películas. Así pues, aunque Bionicle no contaba con ninguna película, utilizando este estilo, la idea era hacer que pareciese que esta colección formaba parte de una película, consiguiendo así que la historia pareciese más auténtica para los niños.

Con el objetivo de llegar a la mayor cantidad de público posible y conseguir mostrar la complejidad de la historia de una forma comprensible para el target al que iba dirigida, se utilizaron una gran variedad de medios, aunque los tres principales sobre los que recayó la historia fueron la página web, los CD-ROM y los cómics. Así pues, como toda estrategia transmedia, los diferentes medios fueron planificados para 
ofrecer una parte de la historia diferente, pero complementaria, de forma que no hubiese ningún tipo de repetición.

Para esta estrategia, imitando a las campañas de promoción de películas, se dio una gran importancia a lo visual para comunicar la historia. Así pues, utilizaron para ello animaciones 3D, gráficas y anuncios con sofisticados efectos. También se lanzaron varios videojuegos de la saga como Bionicle (2003), Bionicle Heroes (2006) o Bionicle Challenge (2007), entre otros, así como aplicaciones y juegos en línea que se encontraban alojados en la página web oficial de Bionicle.

Otro aspecto importante de la estrategia seguida con LEGO Bionicle fue la colaboración con otras empresas como McDonald's o Nintendo, las cuales tuvieron cierta libertad para ampliar la historia. Esto benefició en gran medida al universo de Bionicle, ya que permitió aumentar el número de medios a través de los cuales contar la historia e incluso amplió el universo en sí, porque se permitió que colaboradores como McDonald's diseñasen personajes nuevos para vender en sus Happy Meal.

Como indican los informes anuales de LEGO, el éxito de Bionicle otorgó notables beneficios financieros para la empresa, pero también doto a la empresa de una mayor notoriedad y una mejor percepción de la misma, como se puede observar en las figuras 1 y 2 .

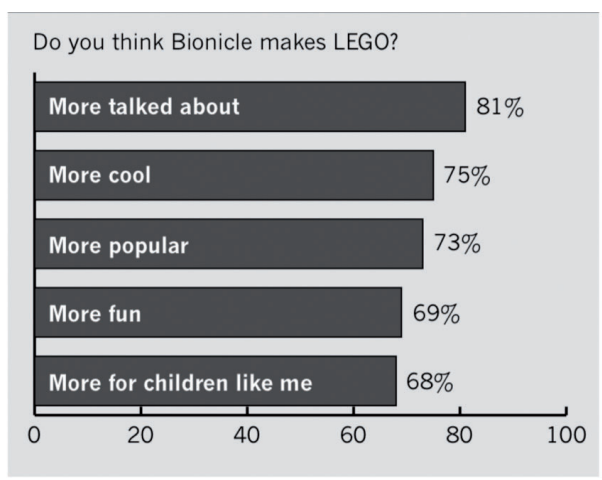

Figura 1. Efecto de Bionicle sobre la marca Lego. Niños de 6 a 11 años Fuente: Fonnesbaek y Melbye Andersen 2005 


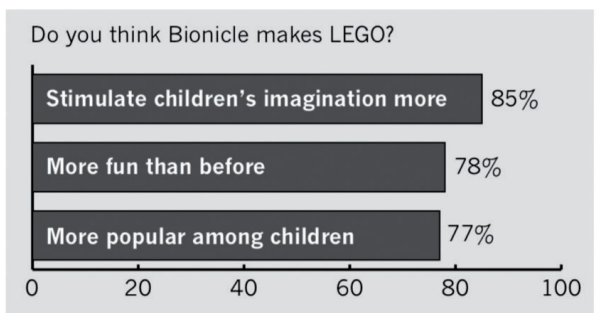

Figura 2. Efecto de Bionicle sobre la marca Lego: Madres de los niños Fuente: Fonnesbaek y Melbye Andersen 2005

En definitiva, la estrategia llevada a cabo por LEGo y la agencia Advance, basada en la narrativa transmedia e imitando las estrategias utilizadas para las películas de Hollywood, consiguió dotar a la saga de Bionicle de un valor añadido respecto a otras colecciones de LEGO y de un vínculo emocional con su público objetivo, cosa que hizo que este se sintiera más unido a los personajes y por ende a la colección y a la marca.

\subsection{La LEgo película}

Todos estos proyectos transmedia en los que había estado y sigue trabajando Lego des de finales de los 90 llegaron a su apogeo en el año 2014, con el estreno de La LEGO película (The Lego Movie).

La película cuenta la historia de Emmet Brickowski, una figura de LEGO que trabaja en la construcción y que no posee ninguna cualidad especial, hasta que por accidente se le queda pegada en la espalda una pieza maestra, convirtiéndose así (según dictaba la profecía) en El Especial. Su misión a lo largo de la película consistirá en vencer al Megamalo e impedir que cumpla sus perversos planes.

La importancia de esta película recae en el hecho que consiguió unir todo el universo de LEGO preexistente en un único contenido, incluidas las colaboraciones realizadas con marcas externas, desde Star Wars y Batman, pasando por Ninjago hasta Hello Kitty o My Little Pony. Esta 
convergencia de universos en uno solo consiguió reproducir en una película lo que los niños de todo el mundo habían estado haciendo durante tantos años. Es decir, jugar con diferentes sets en un mismo lugar mezclando sus historias y universos haciendo que se relacionen entre ellos. Además, no solo se unieron las diferentes colecciones de lego en un único contenido, sino que como resultado de esto, se consiguió crear un contenido y una historia completamente nueva que permitió ampliarla más allá de la gran pantalla, creando sets de LEGO especiales de la película y videojuegos.

La película se podría calificar como un anuncio de noventa minutos, no obstante aunque los productos de LEGO sean la película en sí misma, está escrita de tal manera y su argumento está planteado de tal forma que en ningún momento da la sensación de estar visionando un anuncio. Esto sucede principalmente porque el argumento encaja perfectamente con el universo de LEGO y transmite una serie de valores que casan muy bien con la marca. En este sentido, la película realmente está hablando sobre el trabajo en equipo, el poder de creer en uno mismo y en la propia imaginación, porque realmente hay un constructor en cada uno de nosotros. También habla sobre las diferentes maneras que existen de jugar, ya que no hay una única forma de hacer las cosas y, también, sobre que nunca se es demasiado mayor para crear y creer en la magia. De esta forma LEGO, haciendo honor a su misión, pretendía con la película inspirar y desarrollar a los creadores del mañana.

Como consecuencia, la película recibió muy buenas críticas (con un 96 \% según Rotten Tomatoes) y fue un gran éxito en taquilla, recaudando 469.760.692 \$. Además obtuvo importantes nominaciones en los Óscar (mejor canción original), en los Globos de Oro (mejor película animada) y en los BAFTA, en los que ganó el premio a la mejor película animada, además de otras nominaciones a los Grammy, Premios Annie, Critics Choice Awards y otros festivales. Esto favoreció que se produjesen una serie de spin-offs y secuelas como LEGO Batman: La película o LEGO Ninjago: Maestros del Spinjitzu. Además está previsto el estreno de La LEGO película 2 para febrero del 2019. 


\section{CONCLUSIONES}

La larga trayectoria histórica de LEGO la ha consolidado como una empresa líder en el sector del juguete y como una organización icónica a nivel global. Desde sus inicios adquirió una gran popularidad y ha sabido adaptarse al entorno cambiante para, no solo sobrevivir, sino también crecer económicamente y como marca.

Los cambios más importantes acontecidos en el sector del juguete a lo largo de las últimas décadas han tenido una enorme influencia de los videojuegos y las nuevas tecnologías. Es por ello que, como hemos visto, LEGO apostó por la aplicación de este tipo de tecnologías a sus juguetes, con la creación del set de robótica LEGO Mindstorms o el videojuego LEGO Islands. No obstante, la estrategia de LEGO no se centró únicamente en la tecnología, sino que, sin abandonar su identidad y lo que le ha hecho llegar hasta donde está en la actualidad, es decir, su sistema de construcción por ladrillos, decidió apostar también por las historias. La empresa comenzó obteniendo licencias y colaborando con otras marcas, con las cuales a través de sus juguetes, ampliaba los universos ya creados, como vemos en LEGO Star Wars o LEGO Batman, para posteriormente crear sus propias historias con sets como LEGO Bionicle.

Así pues, siguiendo la idea de Henry Jenkins, según la cual los juguetes son poderosos medios para contar historias, Lego decidió apostar por el LEGO, en concreto el transmedia storytelling, mediante el cual se le otorga un papel esencial al usuario. Utilizando estas historias se consiguió dar un valor añadido al producto y se logró un mayor vínculo emocional con el consumidor final, cosa que se vio reflejada en las ventas y en la percepción que estos tenían de la marca.

Lo cierto es que LEGO es una empresa que, aunque no siempre lo ha hecho, en la actualidad valora enormemente a su comunidad de clientes y a la interacción de los mismos con sus diferentes productos, sobre todo para la generación de contenidos. Es por ello que pone a su disposición recursos a través de los cuales los fans puedan compartir sus creaciones e incluso sean ellos mismos los que propongan la creación de nuevos productos, como es el caso del set LEGo Minecraft, propuesto por un 
usuario en el sitio web LEGO Ideas, donde la comunidad puede proponer nuevos sets y colecciones, potenciando así la creatividad y la imaginación de los clientes.

Por tanto, para finalizar, vemos como ante la situación de crisis a la que se enfrentaba LEGO por la amenaza de nuevas formas de entretenimiento para los niños, basadas en videojuegos y en general la tecnología, la compañía tuvo que dar un giro estratégico hacia la narrativa transmedia consiguiendo así una mayor implicación por parte de la comunidad con el consecuente beneficio para la empresa.

\section{BIBLIOGRAFÍA}

Campos Freire, F. 2008. «Las redes sociales trastocan los modelos de los medios de comunicación tradicionales». Revista Latina de Comunicación Social, 11 (63).

Dunnigan, James F. 2000. Wargames Handbook: How to Play and Design Commercial and Professional Wargames. iUniverse.

Fonnesbaek, J. y M. Melbye Andersen. 2005. «Story Selling: How LEGO told a story and sold a toy». Young Consumers, 6 (3): 31-39.

Galán, E., A. Rodríguez Serrano y J. Marzal Felici (eds.). 2018. Contenidos transmedia para la radiotelevisión de proximidad. EUNSA.

Jenkins, H. 2003. Transmedia Storytelling. Moving Characters from Books to Films to Video Games can Make Them Stronger and More Compelling. Technological Review.

Kress, G. y T. Van Leeuwen. 1998. «Front pages: (The critical) analysis of newspaper layout». Approaches to Media Discourse, 186.

Okuda Benavides, M. y C. Gómez Restrepo. 2005. «Métodos en investigación cualitativa: triangulación». Revista Colombiana de Psiquiatría, 34 (1).

The New York Times. 2009. «Turning to Tie-Ins, LEGO Thinks Beyond the Brick». The New York Times. http://cort.as/-EAEx 


\title{
LA INFLUENCIA DEL ABANDONO DE LAS REDES SOCIALES EN LA MARCA PERSONAL, ESTUDIO DE CASO: EL RUBIUS EN YOUTUBE
}

\author{
Álex Rubio-NaVAlón \\ Universitat Jaume I \\ Stanislava Mrkonjic \\ Universitat Jaume I
}

\section{Resumen}

Las redes sociales mayoritarias han comenzado a entrar en una fase de estancamiento e incluso declive en número de usuarios; personalidades que han sido referencia para sus públicos, influencers clave, estrellas digitales que ya son una de las armas principales de las empresas en internet, han abandonado en masa Instagram, YouTube o Twitter en un intento de protegerse de la esclavitud virtual a la que se han visto reducidos y preservar, incluso, según apuntan algunos de ellos, su propia salud mental. ¿Estamos adentrándonos en una era post social media en el campo de la identidad digital? ¿Hemos de dirigir la mirada a otros caminos en lugar de ignorar un potencial cambio inminente, consistente en el cese masivo del uso de las grandes redes? Para esclarecer el alcance de la nueva y creciente tendencia de abandono digital entre las redes mundiales de usuarios, sus causas y consecuencias, el objetivo de este artículo es analizar los nuevos caminos que se abren para la gestión de la marca personal en internet tras el inicio del declive de las herramientas que hasta el momento han sido los pilares fundamentales de tal acción dentro del entorno digital. Para realizarlo, los autores han analizado en profundidad el caso de «El Rubius», un fenómeno digital con una sólida marca personal, y a su vez con un alcance de millones de personas por publicación. Este usuario ha anunciado su retirada temporal de YouTube, plataforma en la que contaba con una audiencia de $30 \mathrm{mi}-$ llones de usuarios y que constituía su principal fuente de ingresos, como consecuencia de un prolongado periodo de ansiedad.

Durante la investigación, se observa que el empleo de redes sociales como canales de construcción de marcas personales es una tendencia creciente. Sin 
embargo, tras analizar los datos recogidos, se concluye que no existe ni un conocimiento profundo, ni un uso eficiente, de las herramientas para la construcción de la identidad digital que brindan las redes; su aprovechamiento sigue siendo una tarea pendiente.

Palabras clave: identidad digital, redes sociales, social media, YouTube, marca personal.

\section{INTRODUCCIÓN}

\subsection{Justificación del interés del tema abordado}

$\mathrm{L}$ AS REDES SOCIALES HAN SIDO UNO de los grandes indicadores de la influencia de la hiperconexión en la sociedad occidental desde la aparición de internet como herramienta de uso masiva. La democratización y ampliación del alcance tecnológico de la información ha configurado un marco de obligado estudio para cualquier investigador en comunicación, presentando una apasionante evolución de usos, hábitos y costumbres en los confines de las redes sociales, que se han erigido en herramientas de construcción y destrucción de identidades digitales, con alto poder de mutación, cambio y enriquecimiento, a la vez que de desestabilización, influencia y modulación de mentes de acuerdo a un ideal intangible, cuasi mesiánico, percibido colectivamente en las redes sociales y cuidadosamente configurado para representar valores identitarios inalcanzables.

A través del presente artículo pretendemos dar un paso más allá en una rama de importancia de las redes, en una era en la que las redes sociales no son ya una realidad incipiente sino consolidada, y donde comienzan a surgir voces críticas en torno a problemas de privacidad, hiperconectividad y tiempo de uso. En esta ocasión, escogemos un caso concreto de estudio de una de las personalidades que mejor han aprovechado estas redes para generar un impacto en la sociedad, primero con su presencia, y más tarde con su ausencia de las mismas. 


\subsection{Fundamentos de la investigación que se presentan}

Debido a la efímera existencia de las primeras redes sociales que iniciaran la transformación social de la que trata el presente artículo y su actual inoperancia, como Hi5 o MySpace, nos centraremos en las redes actualmente de uso mayoritario, sin descartar un nuevo giro en el futuro próximo, y la aparición de nuevas soluciones de interconexión entre individuos en el ámbito digital. Así, nos limitaremos a Facebook, Twitter, Instagram y YouTube como plataformas de interacción digital en el ámbito 2.0 con mayor número de usuarios diseminados en el mundo, y la figura de un líder de opinión, universalmente llamado influencer, en este caso Rubén Doblas Gundersen, alias «El Rubius», que por su importancia y alcance, puede considerarse como un representante de una generación entera de usuarios de redes sociales, y cuyas acciones pueden verse como precursores de una tendencia más amplia en la sociedad a seguir direcciones similares.

\subsection{Metodología seguida}

Para obtener los objetivos de la presente investigación que se detallan a continuación, se ha realizado un análisis exhaustivo de varios parámetros clave en la presencia y actividad de Rubén Doblas Gundersen, alias «El Rubius», en los canales sociales digitales mencionados en el punto anterior.

En adición a datos basados en cifras cuantitativas obtenidos de herramientas digitales, se ha estudiado también el estilo de interacción y la cultura adoptada en sus discursos, para destilar mejor el perfil social al que se dirige, y sobre el que tiene mayor poder de prescripción.

Además, se ha complementado la metodología con un estudio de prensa tradicional en internet para acceder al seguimiento en tiempo real de las costumbres de la sociedad en el entorno digital. El mismo proceso de revisión, aprobación y publicación de medios especializados no tiene la suficiente velocidad como para representar la realidad del momento en el entorno digital. Este hecho hace imposible la investigación 
de casos puntuales en redes sociales basándose únicamente en fuentes bibliográficas científicas. Incluso la presente investigación podría ser obsoleta cuando llegue el momento de su publicación.

\subsection{Objetivos de la investigación}

El presente artículo busca esclarecer los siguientes puntos de forma general:

a) Cuál es el estado actual del uso de las redes sociales.

b) Qué fases se observan en la evolución del uso de las redes sociales en la segunda década del s. XXI.

c) Qué previsiones pueden hacerse en materia de identidad digital teniendo en cuenta los datos estudiados.

Como objetivos específicos, el presente artículo busca:

a) Determinar el grado de influencia de los líderes de opinión digitales o influencers.

b) Señalar el potencial comportamiento social respecto a las herramientas digitales de interacción en el futuro próximo.

c) Determinar la importancia de la cooperación de varias ramas de conocimiento entre varias ramas sociales para el entendimiento completo del rol de las redes sociales en la vida de las personas.

\section{LAS REDES SOCIALES EN LA SEGUNDA DÉCADA DEL SIGLO XXI}

\subsection{El auge del medio y la emergencia del rol del influencer}

Las redes sociales han sido la primera gran herramienta para el empoderamiento del individuo frente al universo de las multinacionales, los gobiernos y las instituciones globales. En su primera fase, las redes sociales $\mathrm{y}$, en concreto, las cuatro plataformas que observa este estudio 
(Facebook, Twitter, Instagram, YouTube), han sido la plataforma de expresión y desarrollo de identidad libre de una sociedad occidental cansada de clasicismos preestablecidos, en busca de fórmulas rompedoras de presentación, interacción y cooperación social y profesional.

Con el tiempo, un limitado número de usuarios han tomado las riendas del destino digital común, erigiéndose en prescriptores, líderes de opinión o influencers, en campos que van desde lo general hasta lo particular por sectores. El tradicional concepto de celebridad asociado a logros, talento o estatus social, se ve desdibujado y llevado a un plano superficial, temporal y materialista, que se construye (Turner et al. 2000). El influencer se ha convertido en una profesión con altos niveles de lifestyle o estilo de vida mostrado, deseada por muchos y percibida como la manera fácil de alcanzar el estrellato y todo lo adherido a él, de la misma manera que hace una década lo era el reality star, el actor o top model del momento. En la era digital, las vidas de los perfiles célebres tradicionales (no sus vidas públicas, sino las porciones de sus vidas privadas que han quedado inmortalizadas en redes sociales a ojos públicos) pueden haber contribuido a la progresiva cosificación de la privacidad por parte de los públicos receptores, y ello a su vez ha podido llevar a percibir la divulgación de amplias facetas de la propia vida privada como algo normal, incluso necesario (Bronwen y Round 2014).

Se ha consolidado una dependencia creciente del reconocimiento social en el entorno digital, traducido en clics, likes y comentarios, que, según recoge la publicación especializada Brandwatch, se asemeja a la dinámica del experimento de Pavlov, con un creciente número de miembros de la sociedad reproduciendo los comportamientos del animal en dicho experimento (Joyce 2018). De manera paralela, comienzan a proliferar lo que los psicólogos Donald Horton y R. Richard Wohl llaman «relaciones parasociales», en las que el público seguidor de perfiles conocidos, o influencers, en redes sociales acumula tal cantidad de conocimiento sobre ellos, que la sensación de familiaridad y cercanía es inevitable (Horton y Wohl 2013). La diferencia que ocurre en estos casos en redes sociales, es que el carácter unilateral de las relaciones parasociales descritas por Horton y Wohl se transforma en una cierta recipro- 
cidad del individuo influencer hacia el público masivo, llegando incluso a materializarse en relaciones de amistad puntual (altamente documentadas y publicadas) entre estrella y seguidor/a, afianzando el estatus de los primeros y contribuyendo a construir el de los segundos.

Paulatinamente, lo que se suponía privilegio de unos pocos se convierte en la norma, lo esperado por defecto por parte de todos los individuos (Newport 2016). El branding y el estrellato digital ganan tracción como temáticas, hasta el punto en que - un fenómeno que se mantiene todavía en la actualidad- los medios especializados en marketing o mercadotecnia incluyen entre sus contenidos instrucciones o guías para conseguir ser influencer con éxito (Gahan 2017), y dichos contenidos no son cuestionados.

Prestando atención a los momentos de irrupción de las redes sociales, observamos cómo partiendo del seguimiento de figuras ya establecidas en el universo digital el público comienza a ganar conciencia sobre la posibilidad de generar una marca sobre su propia persona, de construirse una identidad, sin necesidad de apoyo por parte de ninguna infraestructura mediática, y nace el concepto de «famoso de cosecha propia», término introducido por Graeme Turner en 2004 y llevado a su máxima expresión en las primeras dos décadas del $\mathrm{s}$. XxI gracias a herramientas digitales en continuo desarrollo. Las redes, entendidas como medios de comunicación, abandonan paulatinamente su tradicional rol representativo, según el cual los públicos buscaban y seguían a perfiles con los que se sintieran identificados, o a los que aspiraban a acercarse, para adoptar un rol «presentador», en función del cual actúan de trampolín para lanzar a cada usuario individual al estrellato digital en términos propios, por derecho propio y sin intermediarios (Marshall 2010).

Durante la segunda década del s. Xxi y a la par que proliferan nuevos perfiles de influencers en campos temáticos tan divergentes como la gastronomía, la música, la moda y el mundo animal, comienzan a emerger $-y$ hacerse, igualmente, extraordinariamente visibles- historias de éxito y fracaso, promesas y escándalos, en la trayectoria de dichos perfiles, recalcando la naturaleza efímera del concepto de influencer (Abidin 2018). 


\subsection{El alcance y rol social de las plataformas de interacción en línea}

En la segunda década del s. XXI, los perfiles influencers se convierten en ocasiones en verdaderas empresas desde el ámbito mercantil por derecho propio. Jóvenes con cierta popularidad se convierten en embajadores de marcas, y el rol de las redes sociales como un canal de crecimiento, conexión y desarrollo identitario se desdibuja en favor de la búsqueda de seguidores a cualquier precio con un fin de monetización e incremento de la autoestima. El número de seguidores se convierte en la medida del valor individual, y los casos de depresión relacionados con el uso (o abuso en ocasiones) de redes sociales se disparan. La incursión de plataformas predominantemente visuales o la apuesta visual de plataformas ya existentes incrementa el valor constructor de identidad digital, a la vez que trivializa su valor.

Ya en 2015, algunas de estas «e-celebridades» deciden retirarse del mundo social digital, en una tendencia capitaneada por Essena O'Neill, pionera en afirmar que las redes sociales no son la vida real y que por ello cambiaba radicalmente su relación con las mismas comenzando, entre otras cosas, a denunciar abiertamente la realidad detrás de cada publicación que había hecho hasta el momento (Hunt 2015) (figura 1).

Sin embargo, el atractivo de una potencial profesión lucrativa y de poco esfuerzo ha seguido ejerciendo mayor influencia en los años posteriores que los casos de retirada de personalidades en Instagram, Twitter, Facebook o YouTube, algunos de ellos de manera trágica.

Algunos influencers, capitaneados por Essena O'Neill, comienzan a denunciar la superficialidad de las plataformas de interacción social en las que no se transmite nada de valor como comunidad, ni se pretende un crecimiento personal o profesional de sus destinatarios, sino que se comunica una imagen superflua a menudo fuertemente ligada a promociones comerciales previo pago, empleándose las redes exclusivamente para la autopromoción y beneficio empresarial. Hasta el año 2015 las plataformas estudiadas no estaban en la obligación legal de especificar qué publicaciones tenían un carácter promocional y formaban parte de una estrategia publicitaria previo pago al influencer, por lo que el público podía tener la percepción de que el mensaje era auténtico y genuino, sin carácter mercantil oculto. 


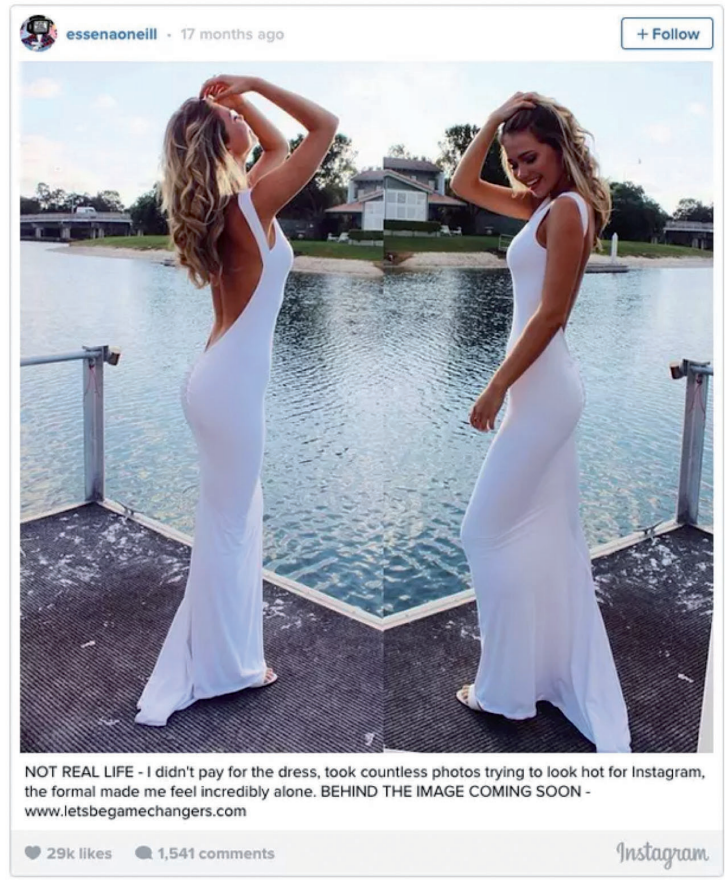

Figura 1. 'NO ES LA VIDA REAL - No pagué el vestido, me hice montones de fotos para intentar salir lo bastante guapa para Instagram, y mi vestimenta me hizo sentir mucha soledad. [...]'

\subsection{EI declive y la paradoja digital}

En el año 2015 comienzan a aparecer las primeras instancias de abandono de las redes sociales por parte de perfiles semiprofesionalizados y estrellas de redes sociales a tiempo completo, acompañados de la explicación de los efectos que su uso ha tenido en la vida personal de los individuos implicados. La percepción de la vida del blogger o blogero, estrella de YouTube, Facebook y posteriormente Instagram, como alguien relajado y despreocupado a quien le llueven ingresos por parte de anunciantes y de las propias plataformas por el simple hecho de tener presencia en ellas con mayor o menor carga y preparación, de repente se encuentra 
con una verdad alternativa, de puño y letra de las personas que han sido dichos perfiles durante un tiempo prolongado.

A partir de ese momento, se detecta la coexistencia de comunidades que perciben el rol de influencer como un futuro idílico, con una identidad sólida, respetada y bien remunerada, con las que reciben y aceptan los testimonios individuales de exinfluencers y pasan a minimizar su actividad en redes sociales. De forma paralela a los seguidores de las identidades estrella en redes sociales, la comunidad global comienza a orientarse en cada vez mayor número hacia la minimización en el uso, o el abandono, de dichas redes sociales.

Incluso en este momento, el peso de la opinión de un perfil influencer es abrumador. Aun así, las comunidades de usuarios comienzan a reclamar el poder de decidir por su futuro en una nueva tendencia democratizadora de disminución en el uso de las principales plataformas:

- Facebook, bajo argumentos de que se ha convertido en campo de cultivo de demostraciones de ira, odio e ignorancia, o incluso de manipulación de la opinión pública y de emisión descontrolada de noticias falsas of fake news, donde la privacidad es cada vez menor a pesar de recalcar lo contrario. El supuesto involucramiento de Cambridge Analytica y, por extensión, la misma Facebook, en los resultados electorales de la campaña presidencial de los Estados Unidos en 2016, ha abonado el terreno para un todavía mayor incremento en el abandono de esta red social.

- Twitter comienza a ser el campo donde se documenta el mayor número de casos de abusos y ataques contra la dignidad individual, y donde el anonimato percibido da a las masas un nuevo y reforzado poder destructor que, en lugar de unir comunidades digitales, las separa y enfrenta (Holmes 2015 y BBC News 2018). Twitter también es el primer campo de batalla de usuarios contra influencers, en el que se han expuesto los detalles de algunos acuerdos entre estrellas de redes sociales y empresas, faceta hasta el momento desconocida de quienes se ganan la vida existiendo en digital (Bennett 2018). 
- Instagram, por la presión de mantener un elevado ritmo de publicación hasta el punto en el que el límite entre la vida real y la digital se desdibuja, y la identidad (en términos de marca personal física) se ve ensombrecida por la identidad digital (en términos de presencia en entornos digitales), impidiendo ejercer, y existir, en el mundo físico. Perfiles con altas cotas de seguimiento, tales como Michael Stipe, componente de la banda musical REM, están aprovechando su estatus para pedir que se reflexione seriamente sobre la manera en la que las redes sociales están cambiando las decisiones tomadas y las conversaciones mantenidas en el plano privado de las personas (BBC News 2018).

- YouTube, por un mercado altamente competitivo debido a un lucrativo futuro percibido por pertenecer al programa para creadores de contenido en la plataforma, YouTube Partner, y requisitos cada vez más restrictivos para acceder a tal nivel, que generan ansiedad y soledad en los creadores y adicción en los públicos.

Las personas dedicadas a formar sobre cómo generar marca personal en redes sociales continúan de forma amplia desoyendo las voces críticas que redundan en la creciente tendencia paralela a abandonar las redes sociales. En la actualidad detectamos la coexistencia de ambas tendencias, sin una clara preferencia social por ninguna de las dos. La disponibilidad continua de sobreinformación en internet y la incidencia universal de la tendencia de buscar, y evaluar, solamente información que sea coherente con los propias creencias, hace que tanto quienes vean en las redes sociales un medio de identidad, reconocimiento e ingresos como quienes vean en ellas una amenaza para la identidad, la salud mental y la gestión del tiempo en la vida real, encuentren la suficiente información para apoyar sus convicciones. El efecto intensificador de Facebook sobre los prejuicios, el confirmation bias, del usuario digital, que quedó demostrado durante la campaña presidencial de 2016 en EE. UU. (Bixby 2016) puede aplicarse a otras facetas sociales de la interacción en línea, donde el ser humano también busca agruparse según puntos en común. 
Surgen ejemplos como la cadena de restaurantes Whetherspoons, del Reino Unido, con cerca de mil restaurantes en el país británico, que ha abandonado las redes sociales en su totalidad, en una acción entendida como parte de protesta de sus relaciones públicas. Según Tim Martin, su presidente (BBC News 2018), que niega la rama promocional de su decisión (Weaver 2018) las redes sociales distraían a los diferentes responsables del servicio al cliente, que era lo que traía los ingresos. Convencido de que las redes sociales no suponen un incremento en la facturación, Martin decide retirar a Whetherspoon en bloque de Facebook, Twitter e Instagram. Las voces críticas apelan a la inoperancia de los responsables de gestión de las redes sociales para fundamentar la decisión, y que en cualquier caso, el rol de una red social nunca fue puramente comercial; las redes sociales tienen un funcionamiento mucho más complejo, en el que sigue existiendo la correlación entre presencia y uso efectivo de redes sociales y facturación, pero no existe la causalidad que antaño sí se daba en los orígenes de las mismas que aprovechaban el factor novedad.

En 2018 la tendencia se extiende a varios medios digitales, que, a través de casos de estudio y experimentos individuales convertidos después en testimonios, ponen el foco sobre los beneficios de abandonar las redes sociales temporalmente para descubrir realmente el efecto nocivo que están teniendo sobre la vida y estado de salud del individuo (Fierberg 2018). Véase la figura 2.

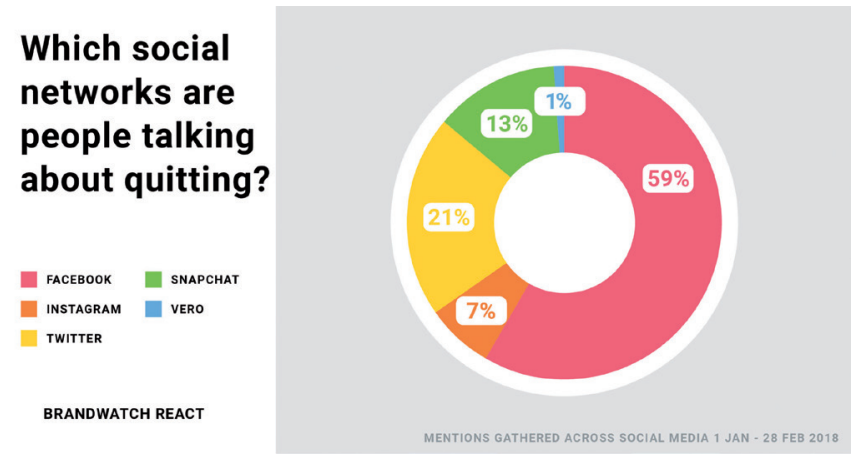

Figura 2. Resultados del análisis de Brandwatch React sobre las redes con mayor potencial de sufrir abandono (Joyce 2018) 


\section{ESTUDIO DE CASO: EL RUBIUS}

\subsection{Perfil e industria}

Rubén Doblas, alias «El Rubius», comienza su andadura en YouTube en diciembre de 2011 con vídeos en los que aparece comentando videojuegos. A fecha de 11 de septiembre de 2018, acumula 765 vídeos repartidos en 22 listas de reproducción, que cuentan con un total de 6.878.980.157 vistas. Las temáticas de sus vídeos se reparten entre el análisis de videojuegos desde la perspectiva del usuario y juegos en directo por un lado, y por otro la documentación de su vida privada, a través de sesiones de confesiones personales y de análisis de aspectos privados de su vida, sus viajes y bromas gastadas con amigos.

\subsection{Cifras de seguimiento y perfil de público}

Instagram: http://cort.as/-Emmf, 8.682.242 millones de seguidores (7/9/2018)

YouTube: https://www.youtube.com/elrubiusomg, 30.833 .404 seguidores $(13 / 9 / 2018)$

Facebook: http://cort.as/-Emk1, 6.9 millones de fans (7/9/2018)

Twitter: https://twitter.com/rubiu5, 11.568 .850 seguidores (25/9/2018)

Google+: http://cort.as/-F2lg, 803.815 seguidores (25/9/2018)

En julio de 2018 y con 30 millones de seguidores, se convierte en el cuarto perfil de YouTube más seguido del mundo, el segundo de habla hispana y el número uno en España (Hidalgo 2018).

\subsection{Frecuencia, tono y estilo de la comunicación}

Los videos de El Rubius comparten una técnica de realización y una línea similar: un tono fresco y alegre, positivo y culturalmente peninsular, orientado a un público adolescente. El discurso observado es informal hasta rayar en lo coloquial en casi todas las ocasiones excepto en sus confesiones personales, y en particular la que graba para despedirse 
temporalmente de las redes sociales, en la que adopta un tono inusualmente grave en comparación con su discurso habitual. Rubén Doblas construye, a través de su canal, un sentimiento de comunidad y pertenencia que responde a una forma de capital social (Bordeaux 1986).

Tomando como partida el 11 de diciembre de 2011 (fecha de apertura del canal de YouTube), los 765 vídeos grabados hasta la fecha de cierre del presente estudio (11 de septiembre de 2018) indican una frecuencia media de publicación de 9,4 vídeos al mes, o un vídeo cada 3,1 días.

El Rubius emplea Twitter para difundir concursos propios, ofrecer regalos y generar creación de comunidad, además de su rol primordial como difusor del contenido de vídeo subido a la plataforma YouTube. La frecuencia de publicación en esta red, tomando como partida la fecha de alta en la misma y el número de tuits emitidos hasta el 25 de septiembre de 2018 es de 9,3 tuits al día.

Rubén Doblas cuenta con el tuit más retuiteado del mundo en 2016: «Limonada» (Cantó 2016). Véase figura 3.

Los usuarios que hacían retuit o RT del mismo entraban en el sorteo de varias videoconsolas.

En Facebook cuenta con una menor actividad, a razón de una publicación cada cinco días aproximadamente (fuente: Likealyzer). En esta red cuenta con tan solo cuatro vídeos nativos, concentrando su actividad en la publicación de fotografías (57\%) y vídeos vía enlace a YouTube (43\%). Contrariamente a lo que se pueda esperar, Facebook no es su método principal de difusión del material de YouTube; analizando los datos recogidos, se concluye que lo es Twitter.

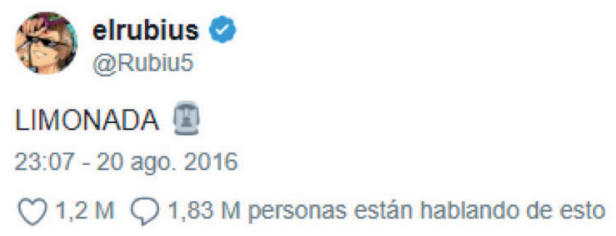

Figura 3. Para celebrar 20 millones de suscriptores en su canal de YouTube, Rubén Doblas «El Rubius» organizó un concurso en Twitter. La figura superior muestra el tuit que daba el pistoletazo de salida a dicho concurso (Cantó 2016) 
En Instagram, Rubén Doblas documenta su día a día con una frecuencia media de 2,5 publicaciones diarias (estimación basada, a fecha de 25 de septiembre 2018, en el cociente entre su tiempo de alta en la red y el total de publicaciones realizadas), profundizando en la conexión íntima con su público en lo que Crystal Abidin denomina «contenido de relleno», contenido de tinte emocional, en su libro sobre celebridades digitales (Abidin 2018).

El usuario estudiado utiliza Google Plus en exclusiva para la difusión de sus videos, en lo que se entiende una acción pura de SEO. En esta red social tiene 803.860 seguidores a fecha de 14 de septiembre de 2018.

\subsection{Crisis: causas, evolución y desenlace}

En mayo de 2018, Rubén Doblas decide abandonar temporalmente la plataforma YouTube y lo hace público mediante un vídeo (Doblas 2018). Su grabación pasa a ser un testimonio valioso sobre la otra cara del mundo digital (Hidalgo 2018), y aclara en qué consiste la dependencia de las redes a la que otros perfiles llevaban un tiempo refiriéndose. La sobreexposición y la ansiedad generada por producir y publicar contenido innovador a un ritmo constante es un ejemplo de lo que otros exinfluencers habían denominado «esclavitud digital».

Aunque el personaje de Rubén Doblas, El Rubius, centraba su actividad en YouTube con un vídeo documentado y especializado cada 3,1 días de media, su presencia en Twitter, Facebook y Google Plus contribuía a dispersar recursos.

Durante su hiato, el influencer ha admitido en los medios que la actividad continuada en redes sociales ha contribuido a una alteración de su personalidad que ha sido difícil detener, en lo que entendemos como una ruptura en el desdoble entre la persona y el personaje (Hidalgo 2018) en un reportaje en el que enumera las fases por las que ha pasado hasta decidir volver a estar activo en YouTube. 


\subsection{Trascendencia del caso de El Rubius en internet}

Aunque varios otros perfiles destacados ya habían hecho lo propio en 2015, 2016 y 2017, en España los medios comienzan a hacerse eco de la acción de El Rubius y sobre todo, de los motivos. A raíz de su decisión, el debate social alrededor de los peligros detectados en las plataformas de interacción en línea y de la toxicidad en internet comienza a aumentar. Se observa, de nuevo, la coexistencia de quienes apoyan la decisión de minimizar o eliminar el uso de redes sociales y evitar así la sobreexposición, con quienes consideran la de influencer una profesión bien pagada, fácil y privilegiada, y critican el que perciben como «victimismo fácil» (Siccardi 2018). Adicionalmente, se da mayor cobertura a otros casos de abandono de redes sociales, se visibiliza el problema de la sobreexposición, la adicción y la sensación de soledad tras el uso prolongado de Facebook, Twitter, Instagram o YouTube, y aumenta el escrutinio de todas las herramientas digitales de las que se dispone en occidente en la actualidad.

El portal de análisis de marcas Brandwatch (presente en EE. UU., Reino Unido, Francia, Alemania, España, así como en el mercado asiático y el latinoamericano) vuelve a publicar en 2018 un estudio llevado a cabo en 2016, y que ya entonces señalaba una tendencia del usuario hacia el abandono de las redes sociales, pero al que en España no se le ha dado importancia hasta que una figura prominente en el país ha puesto de manifiesto la realidad (figura 4).

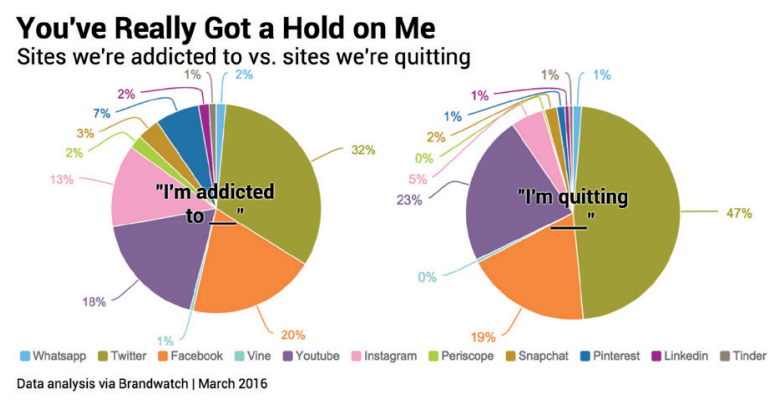

Figura 4. Resultados del análisis de Brandwatch React sobre la adicción e intención de abandono con respecto a diferentes redes sociales (Joyce 2018) 


\section{RESULTADOS DE LA INVESTIGACIÓN}

La investigación permite visualizar la superficialidad inherente a la actuación en redes sociales: con el paso del tiempo y la consolidación de las mismas, unida al desarrollo de los influencers digitales, pasamos del «mejora en aquello que se te da bien y utilizarlo para ayudar a otros/ sé tan bueno que no se te pueda ignorar» al «filtra cada minuto de tu vida para enseñarle al mundo lo perfecta que es/publica tanto que no se te pueda ignorar» (Newport 2016).

La marca personal es concebida como la marca de un personaje, una marca ficticia para una vida ficticia sin ningún fin más allá de la autopromoción vacía, en ocasiones sin una conexión real con la esencia intrínseca de quien la expone. Se pierde la finalidad con la que se crearon las redes sociales, con un sentido relacional en esferas digitales en la que los objetivos de las mismas se basaban en la comunicación (en la medida en que ayudan a poner en común conocimientos), en la comunidad (posibilitan encontrar e integrar comunidades) y en la cooperación (facilitan hacer cosas juntos, compartir y encontrar puntos de unión) (Ponce 2012). Se puede entender el inmenso impacto de las marcas sólidas en las vidas de los aspirantes a una, y lo fácilmente influenciables que son los usuarios a la hora de orientar sus propios recursos digitales y marcas personales a fines no alineados con sus intereses de comunicación.

El análisis del grado de aceptación social de las redes sociales y del caso de El Rubius sugiere una evolución palpable del universo digital hacia un uso selectivo y minimizado. Quizá esta tendencia permita especializar las diferentes plataformas de interconectividad hasta que cumplan en exclusiva su acometido original, y se pueda evitar la mezcla de usos, hábitos y especialidades. Tras el periodo de acogimiento masivo, seguido de un periodo de abandono masivo, cabe esperar una tercera oleada de normalización en el uso de las redes sociales, habiendo superado el boom actual y sus consecuencias negativas (la universidad de Pittsburgh estudió la correlación entre el uso de redes sociales y la incidencia de la depresión en estudiantes). No es que ya no exista este segmento de la población; en 2016 ya se perfiló una clara tendencia de 
abandono, los llamados «desconectados» (Velasco 2016), que decidieron dejar atrás todo asomo de relación digital y centrarse en las relaciones personales cara a cara. Lo que este estudio ha observado es que la coexistencia de las posturas opuestas de una etapa anterior (hiperconectados frente a desconectados) ha evolucionado hacia un término medio en el que se retoma el uso de las redes sociales, pero con mucha más cautela, con fines bien definidos y con la percepción de «vida fácil, ingresos millonarios» desmentida en su mayor parte tras contar con el suficiente número de testimonios de primera mano atestiguando la falsedad de tal percepción.

Esta cuarta fase de las redes sociales, que sigue a las de descubrimiento, auge y abandono, es posiblemente la fase ideal para contemplar el uso de las herramientas digitales como medios de construcción de marcas personales y la vuelta a la propuesta de Newport mencionada anteriormente: perfeccionar un conocimiento o habilidad y comunicarla de manera que aporte un valor afianzado. Tras el batacazo mediático que las mismas plataformas sociales han tenido a raíz de diversos escándalos y problemas anteriormente mencionados, puede parecer complicado volver a encontrarse con perfiles autopromocionados desde la superficialidad y frivolidad del aspecto físico, la vida fácil y la ausencia de aspiraciones de cierto calado, siendo poco más que la versión digital y abierta de las revistas de moda de turno de los años noventa.

Adicionalmente, la nueva fase postredes en la que está entrando la sociedad puede contribuir al establecimiento paulatino de una nueva conectividad digital entre individuos conscientes, un pensamiento crítico más afianzado y un mayor escrutinio también de las marcas personales ajenas, con el fin de invertir tiempo y atención solo en aquellas que aporten un valor añadido a la propia trayectoria, a la propia marca.

Se ha podido observar un largo periodo de coexistencia entre quienes rechazan el rol de las redes sociales, como la campaña de Essena O'Neill para The Guardian, publicada ya en 2015 (Hunt 2015), o la tribu urbana de los desconectados (Velasco 2016) y quienes documentan la cultura de la aspiración al estrellado mediático digital, que se encontraban con frecuencia entonces y que todavía en 2018 documentan casos de éxito 
(Lansat 2018). Esto dificulta realizar una clara delimitación cronológica de las fases en la evolución de la marca personal en las redes sociales.

En el estudio del caso de El Rubius, se ha observado que su decisión de dejar temporalmente Youtube no ha ocurrido en detrimento del número de suscriptores de su canal, habiendo continuado el crecimiento durante sus tres meses de inactividad. No se ha podido esclarecer qué porcentaje de dicho crecimiento se ha dado como una muestra de apoyo por la postura crítica del joven con el efecto de la red en su salud.

\section{CONCLUSIONES}

El estudio permite concluir que, a medida que esta tendencia de abandono de redes sociales se extiende, los usuarios aprenden a emplear con mayor concienciación las mismas para el desarrollo de la identidad, puesto que se expone y visibiliza una realidad diferente a la percibida que genera un debate.

De igual forma, se percibe como necesaria una mayor conciencia por parte del usuario respecto a que la exposición en redes sociales configura, voluntaria o involuntariamente, una percepción externa que genera una marca personal, por lo que estos deben ser conscientes de que es preciso distinguir entre sus usos lúdicos o de entretenimiento y los orientados a un fin de creación de marca comercial. Puesto que, al margen de su naturaleza, la misma actividad en una red social configura la identidad digital de quien la lleva a cabo.

Por otro lado, las iniciativas formativas en el uso de redes sociales, cuyo fin último puede ser la alfabetización digital de los asistentes, se ciñen a dotar a estos últimos de habilidades operativas, pasando por alto en muchas ocasiones el otro componente esencial en la adquisición de una alfabetización digital efectiva: el acceso, evaluación y reflexión crítica sobre el contenido emitido y recibido (Lluna y Pedreira 2017).

Respecto a las metodologías de investigación académica en el campo de las redes sociales, se intuye la necesidad de innovar en el acceso y tratamiento de fuentes de investigación para cubrir el segmento de las 
redes sociales y en general, el segmento digital, cuya alta modulación, transformación y vertiginoso cambio no se puede cubrir en su totalidad por las metodologías tradicionales. Durante la redacción de este artículo, se ha detectado la necesidad de recurrir en mayor medida a documentación e investigaciones en tiempo real y herramientas digitales más que a libros científicos para analizar situaciones puntuales y tendencias de nueva aparición, y recurrir a la literatura científica para cubrir marcos teóricos de base psicológica o filosófica.

Se ha observado que los mismos perfiles pioneros de influencers que han marcado el uso masivo de las redes sociales y señalado tendencias de consumo, están ahora virando en un número trascendente hacia la sensibilización sobre el abuso, o mal uso, de las mismas plataformas que hace no tanto tiempo les dieron una mayor exposición a ellos, sus identidades y sus trabajos. Incluso, en la actualidad, se están creando portales de sensibilización con el fin de disminuir la amplia dependencia de la sociedad de las redes sociales y darles, de nuevo, libertad (Eyck 2018).

El estado actual de los entornos digitales permite un análisis fidedigno y actualizado de un fenómeno acotado en el tiempo tan solo siguiendo las pautas del design thinking: recogiendo microdemostraciones de comportamiento, extrapolando e iterando con frecuencia.

\section{BIBLIOGRAFÍA}

Bennett, O. 2018. «The Wild-West of Infuencer-Dom: Will Social Media Stars Continue to Rise?». The Independent. http://cort.as/-EAFe Bixby, S. 2016. «"The end of Trump”: How Facebook Deepens Millennials' Confirmation Bias». The Guardian (International Edition). http://cort. as/-EAFi

Bourdieu, P. 1986. «The Forms of Capital». En Handbook of Theory and Research for the Sociology of Education, 241-258. Richardson, J. Westport, ct: Greenwood. 
Bronwen, T. y J. Round. 2014. «Introduction». En Real lives, Celebrity Stories: Narratives of Ordinary and Extraordinary People Across Media. London: Bloomsbury.

Cantó, P. 2016. «Una palabra, un millón de retuits: el Rubius se cuela en el top de tuits más compartidos de la historia». En El País. http:// cort.as/-EAFm

Doblas, R. 2018. Me voy a dar un tiempo. http://cort.as/-EAFn

Editorial. 2018. «R.E.M.'s Michael Stipe: "I'm Quitting Instagram this Week"». En bbc News. http://cort.as/-EAFp

Editorial. 2018. «Millie Bobby Brown Quits Twitter After Being Trolled. En: bbc News. 2018. http://cort.as/-EAFs

Editorial. 2018. «Whetherspoon Pub Chain Shuts its social media accounts».bbc News. http://cort.as/-EAFt

Eyck, Caroline T. 2018. «Quitting Instagram Taught Me How to Truly Experience and Document My Life Again». Quartz. http://cort.as/EAFv

Fierberg, E. 2018. «I Quit Social Media for a Month — and it was the best choice I've ever made». Business Insider. http://cort.as/-EAFz

Gahan, B. 2017. «The Best Social Media Influencers Do These 5 Things». Adweek. http://cort.as/-EAG

Hidalgo, E. 2018. «El Rubius deja YouTube "unos meses” por problemas de ansiedad». El País. http://cort.as/-EAG0

—. 2018. «El Rubius, al alcanzar los treinta millones de suscriptores: “Ahora soy más tímido"». El País. http://cort.as/-EAG1

Holmes, M. 2017. «Should I Quit Twitter?» Hashtag. http://cort.as/EAG3

Horton, D. y R. Wohl Richard. 1956. «Mass Communication and ParaSocial Interaction». Psychiatry, 19 (3): 215-229. http://cort.as/-EAG8 Hunt, E. 2015. «Essena O’Neill Quits Instagram Claiming Social Media "is not real life"». The Guardian. http://cort.as/-EAGA

Joyce, G. 2018. «I'm Quitting Social Media: Will We See a Shift in Platform Use in 2018?» Brandwatch. http://cort.as/-EAGD 
Lansat, M. 2018. «A Millennial Who Left her 6-Figure Job at Google to Be a Full-Time Social Media Influencer Explains Why She Was Willing to Take the Risk». Business Insider. http://cort.as/-EAGE

Lluna, S. y J. Pedreira. 2017. Los nativos digitales no existen: cómo educar a sus hijos para un mundo digital. Vizcaya: Deusto Ediciones.

Marshall, P. D. 2010. «The Promotion and Presentation of the Self: Celebrity as Marker of Presentational Media». Celebrity Studies, 1 (1): 35-48. http://cort.as/-EAGI

Newport, C. 2016. «Quit Social Media. Your Career May Depend on It». The New York Times. http://cort.as/-EAGO

Orsini, L. 2015. «I Quit Twitter And My Life Got Better. Here's Why I'm Going Back». Forbes. http://cort.as/-EAGQ

Ministerio de Educación, Cultura y Deporte. 2012. Redes sociales Definición de redes sociales. http://cort.as/-EAGS

Schaefer, M. 2018. «This Large Company Just Quit Social Media. Should You?». Businesses Grow. http://cort.as/-EAGW

Siccardi, X. 2018. «El Rubius anuncia que se retira de YouTube por estrés y ansiedad». La Vanguardia. http://cort.as/-EAGZ

—. 2018. «Apoyo y críticas: internet reacciona a la retirada temporal de El Rubius». La Vanguardia. http://cort.as/-EAGa

TEDxTyson. 2016. Why you should I quit social media. http://cort.as/$\mathrm{EAGb}$

Turner, G. 2004. Understanding Celebrity. Los Angeles: Sage.

Velasco, I. 2016. «Desconectados: la nueva tribu urbana que abandona internet para abrazar la vida real». El Mundo. http://cort.as/-EAGc

Weaver, M. 2018. «Wetherspoon Founder Denies Social Media Account Closure is Stunt». The Guardian (International Edition). http://cort. as/-EAGd

West, L. 2017. «I've Left Twitter. It is Unusable for Anyone but Trolls, Robots and Dictators». The Guardian. http://cort.as/-EAGf

—. 2018. «I Quit Twitter and It Feels Great». The New York Times. http:// cort.as/-EAGg 


\section{LA PANTALLA TRANSPARENTE: CÓMO LA COMUNICACIÓN INSTITUCIONAL PUEDE SER MÁS TRANSPARENTE APOYÁNDOSE EN LAS NUEVAS TECNOLOGÍAS}

RADU TRĂSCĂU

CEINDO - Universidad Abat Oliba CEU

\section{Resumen}

En España, la publicidad activa, requerida a la Administración Pública, en la Ley de la Transparencia 19/2013 puede ser un punto de partida importante para los profesionales en la comunicación digital. Con la ayuda de las nuevas tecnologías se puede aumentar el grado en cual la información llega a los ciudadanos.

Hoy en día, disponemos de todos los avances informáticos necesarios para que estas nuevas plataformas de comunicación se puedan convertir en un fenómeno global y servir al acercamiento y la transparencia entre las administraciones públicas y los ciudadanos.

La investigación tratará de responder a dos preguntas: ¿cuál es el reto de las nuevas tecnologías en relación con la comunicación institucional? y ¿cuáles son las más acertadas herramientas informáticas para potenciar la transparencia y la participación ciudadana por parte de las administraciones públicas? Para ello, realizaremos un análisis semiótico partiendo de los conceptos de: símbolo e imagen.

A partir del análisis de ambos elementos, intentaremos descubrir nuevas modalidades de captar la atención del público y las formas de generar más interactividad en el mundo virtual, entre los ciudadanos y la administración pública.

Para este estudio se ha realizado una selección de una muestra de sitios web institucionales, landing pages, blogs y aplicaciones compatibles con smartphones.

Después de analizar a nivel semiótico dichos materiales, se ha realizado una clasificación de elementos que deben de estar presentes en la comunicación digital para que dichos mensajes e informaciones lleguen de forma óptima al ciudadano.

Palabras clave: nuevas tecnologías; transparencia; comunicación institucional; administraciones públicas. 


\section{ANTECEDENTES}

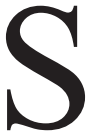

E eSTÁ Hablando DE haCe TIEMPO de la necesidad de más transparencia en la comunicación institucional de los organismos públicos que nos gobiernan, sin embargo una ley que se refiere estrictamente a la transparencia fue aprobada en España apenas en 2013.

La publicidad activa, requerida a la Administración Pública, en la Ley de la Transparencia 19/2013 representa un punto de partida importante para los profesionales en la comunicación digital, que tienen ahora el apoyo legal para implementar nuevas estrategias de comunicación institucional utilizando como plataforma una diversidad de herramientas digitales. Asimismo, que con la ayuda de las nuevas tecnologías puedan elevar el grado en cual la información llega a los ciudadanos y el porcentaje en cual ellos puedan interactuar constantemente con la administración pública.

Hoy en día, disponemos de todos los avances informáticos necesarios para que estas nuevas plataformas de comunicación se puedan convertir en un fenómeno global y servir al acercamiento y la transparencia entre las administraciones públicas y los ciudadanos.

De la misma manera, a las marcas reconocidas internacionalmente, la Administración Publica puede hacer uso de las nuevas plataformas multimedia para mejorar su comunicación institucional y generar más transparencia para sus proyectos de interés público.

Cuando nos referimos a las nuevas tecnologías debemos de entender que las aplicaciones de ellas mismas representan una sinergia de diversos sistemas informáticos que deben de comunicarse entre sí. Por lo tanto, el estudio va enfocado hacia esas herramientas digitales finales, como serían los micrositios, los blogs o las aplicaciones para móviles.

Para comprender como podemos, de forma real, mejorar la comunicación de las instituciones públicas españolas, es importante recordar y definir conceptos como: relaciones públicas, comunicación institucional, gabinetes de comunicación y transparencia.

Nobel destaca el hecho que «las relaciones públicas y la comunicación institucional en la República Argentina tienen una historia de cerca de 
sesenta años. Los comienzos se sitúan en la década de 1950, con el surgimiento de las primeras prácticas profesionales sistemáticas promovidas en algunas empresas multinacionales estadounidenses, que replicaban modelos exitosos que se estaban desarrollando por entonces en las casas centrales de su país de origen» (Nobel 2016, 3288).

Si nos referimos a la profesión de comunicador social, descubrimos que la comunicación institucional, igual que las otras carreras humanísticas y sociales, no tiene incumbencias profesionales, lo que significa que no requiere obligatoriamente formación universitaria ni matriculación en una asociación profesional para ser ejercida. Ello, explica L'Etang, puede impactar en «el estatus profesional [que] sigue siendo un objetivo escurridizo para los profesionales de las relaciones públicas, puesto que el acceso a la profesión no está controlado por la preparación o por la pertenencia a un organismo profesional» (L'Etang 2009, 74).

Tanto la comunicación institucional como la comunicación política tienen una importancia mayor en lo que significa la transparencia de una administración publica. Como Cannel nos indica, «la comunicación política es el campo de estudio que comprende la actividad de determinadas personas e instituciones (políticos, comunicadores, periodistas y ciudadanos) en la que se produce un intercambio de información, ideas, actitudes en torno a los asuntos públicos. Con otras palabras, la Comunicación Política es el intercambio de signos, señales, o símbolos de cualquier clase, entre personas físicas o sociales, con el que se articula la toma de decisiones políticas así como la aplicación de estas en la comunidad» (Canel 1999, 23-24).

Los gabinetes de comunicación son aquellos departamentos de una institución que cuidan de la imagen de una organización. Del mismo modo que Ramírez se refiere a los departamentos de comunicación como a «las fuentes activas, organizadas y habitualmente estables de información que cubren las necesidades comunicativas tanto internas como externas de aquellas organizaciones y/o personas de relieve que desean transmitir de sí mismas una imagen positiva a la sociedad influyendo de esta forma en la opinión pública» (Ramírez 1995, 76). 
Para definir el ámbito de los departamentos de comunicación es imprescindible hablar sobre los públicos objetivos de la comunicación de una institución. Estos se dividen básicamente tres grupos: «el mercado (clientes-votantes y potenciales), el público interno (los empleados de la empresa o institución), y las instituciones (la sociedad). Y uno de los principales canales de llegada a estos grupos son los medios de comunicación social» (Rodas 2015, 149).

En este contexto en cual las nuevas tecnologías son una herramienta por cual muchos profesionales de la comunicación institucional apuestan, Ana Almansa afirma que «internet en general y las redes sociales en particular han abierto un abanico de nuevas posibilidades a las instituciones en las relaciones con los públicos. En el siglo XXI, gracias a internet, las instituciones podrán tener un canal abierto de comunicación directa y permanente con sus públicos, especialmente con la ciudadanía. Podrán facilitarles información a la misma vez que reciben sus comentarios y opiniones. Y todo, de forma directa, sin necesidad de intermediarios» (Almansa 2014, 24).

Para reforzar la importancia de utilizar nuevas plataformas digitales en la comunicación institucional, Ana Almansa, citando a Seitel, argumenta que «las nuevas tecnologías e internet no aportan únicamente mejoras en la gestión de la comunicación. Los sitios web han supuesto grandes ventajas y oportunidades para quienes gestionan la comunicación». Seitel (2002) destaca principalmente tres. La primera es que internet permite ofrecer a públicos amplios y dispersos, a la ciudadanía en general, extensa información sobre las instituciones y sus proyectos. El segundo aspecto que destaca Seitel es que se puede trabajar en tiempo real, la inmediatez y la posibilidad de respuesta de manera instantánea. Y el tercer aspecto que destaca Seitel es el de la segmentación, posible en internet, y que supone una mayor efectividad en la comunicación. «Adecuar el mensaje al público al que se dirige ayuda a que la comunicación sea más efectiva» (Almansa 2014, 24). 


\subsection{Argumentación del estudio}

El presente artículo se plantea como un estudio comparativo entre las capitales de comunidad autónoma de España bajo el contexto de la Ley de Transparencia votada en 2013. En dicho acto normativo están estipuladas una serie de obligaciones que deben ser cumplidas por parte de las instituciones públicas $\mathrm{y}$, por lo tanto, los ayuntamientos

Tras consultar el portal de tesis doctorales, Teseo, se puede observar que la mayoría de las investigaciones publicadas vinculadas a la transparencia institucional son del área del derecho. Existen tesis doctorales que hacen referencia a las nuevas tecnologías y sus efectos beneficiosos para la comunicación, pero se limitan solo a analizar portales web y no van más allá en analizar y comparar herramientas digitales distintas, destinadas a la comunicación institucional.

Con respecto al estudio comparativo que tiene como universo las capitales de las comunidades autónomas, se pueden encontrar solo tesis que hacen referencia a la transparencia en la comunicación institucional en España, basando sus investigaciones estrictamente en las páginas web de los municipios y presentando únicamente unas posibles buenas prácticas en la comunicación digital en dichas instituciones. Por lo tanto, podemos afirmar que el tema elegido para el presente artículo es actual y original.

En el universo de investigaciones sobre la transparencia y la comunicación institucional de las administraciones públicas, encontramos varias iniciativas y estudios enfocados al contenido, a la información que se lanza al espacio público.

Con el presente artículo, intentamos ir más allá de lo que se comunica y ver la forma que se adopta para hacerlo. Por lo tanto, nuestro estudio nos va hacer reflexionar sobre la comunicación como instrumento que se concretiza en forma de canal de difusión de información y de colaboración entre las instituciones públicas y los ciudadanos. De esta forma, no proponemos analizar las aplicaciones móviles destinadas a las comunicación institucional de los ayuntamientos de las capitales de 
comunidades autónomas y ver en qué forma ellas son un instrumento útil para la transparencia tal como la definimos en el primer apartado de este artículo.

\section{METODOLOGÍA}

\subsection{Técnicas de investigación}

Para llevar a cabo la presente investigación vamos a utilizar técnicas cuantitativas (análisis de contenido), basándonos en una observación de las aplicaciones móviles oficiales de los ayuntamientos tenidos en cuenta para el estudio en el periodo septiembre-octubre 2018.

Hemos realizado una análisis de contenido, teniendo en cuenta los patrones semánticos específicos a la comunicación digital. Asimismo, hemos analizado comparativamente las aplicaciones móviles oficiales de los ayuntamientos de las capitales de comunidades autónomas.

Con el propósito de analizar los resultados de nuestro estudio sobre las aplicaciones móviles en relación con los niveles de transparencia de la comunicación institucional de las administraciones públicas locales de España hemos apelado al método ya validado y a los criterios de evaluación de Mapa Infoparticipa.

\subsection{Análisis de contenido: criterios aplicaciones móviles}

Con el propósito de comparar las aplicaciones de móvil oficiales de los ayuntamientos tomados en cuenta para este estudio, hemos cogido 22 criterios objetivos de análisis agrupados en cinco categorías: la información disponible a los usuarios, tipos de mapas disponibles en la aplicación -servicios a los cuales tienen acceso los ciudadanos a través de la aplicación-, actualizaciones y accesibilidad, y tecnologías incorporadas en la aplicación.

Los 22 criterios que hemos considerado para el análisis han surgido de la investigación previa sobre las aplicaciones móviles institucionales 
en la cual se han constatado las funciones que se ofrecen a través de estos instrumentos. De tal manera, que la mayoría de los criterios presentes, tienen al menos una incidencia entre las aplicaciones investigadas.

Los criterios entre las aplicaciones analizadas son aquellos que forman parte de las siguientes dos categorías: actualizaciones y accesibilidad, y tecnologías incorporadas en la aplicación. En estos dos apartados, junto a los criterios por los cuales encontramos mínimo una incidencia, hemos adjuntado otros que son de real importancia para la evolución tecnológica del segmento de aplicaciones móviles en general. Un ejemplo claro lo consiste el criterio que se refiere a las tecnologías de tipo realidad virtual o realidad aumentada. También hemos considerado importante añadir un criterio con respeto a la accesibilidad que ofrece la aplicación a las personas con discapacidades.

Para la presente investigación se han tomado en cuenta los siguientes 22 criterios de evaluación:

- La información disponible para los usuarios

1) Los usuarios tienen acceso a información relevante vinculada a su comunidad.

2) Los usuarios disponen de vídeos informativos sobre su comunidad.

3) Los usuarios tienen acceso a información personal vinculada a trámites administrativos a nivel local.

4) Los usuarios disponen de una agenda de eventos públicos.

5) Los usuarios disponen de un listado de asociaciones y organizaciones de la comunidad.

6) Los usuarios disponen de un listado de números de teléfono de interés local.

- Tipos de mapas disponibles en la aplicación

7) Los usuarios tienen acceso a un mapa con las instituciones publicas.

8) Los usuarios tienen acceso a un mapa con las farmacias más cercanas. 
9) Los usuarios tienen acceso a un mapa con las zonas fijas y móviles para la recolección selectiva de basura.

10) Los usuarios disponen de un mapa con informaciones sobre la calidad del aire/agua.

- Servicios a los cuales tienen acceso los ciudadanos a través de la aplicación

11) Los usuarios pueden señalar aquellos problemas con los que se encuentran en su comunidad.

12) Los usuarios tienen acceso a un servicio de atención pública al ciudadano (live chat, cuenta de Twitter).

13) Los usuarios tienen acceso a los procesos participativos iniciados por la administración local.

14) Los usuarios pueden pedir cita previa para distintos trámites o realizarlos.

15) Los usuarios disponen de un buscador de puestos de trabajo disponibles en su comunidad.

- Actualizaciones y accesibilidad

16) Actualizaciones recientes de contenidos (últimos tres meses).

17) Ofrecen todas las funciones incorporadas en una sola aplicación.

18) La aplicación dispone de funciones que facilitan el acceso a la información a las personas con discapacidad.

19) Los usuarios son calificados mediante un registro.

- Tecnologías incorporadas en la aplicación

20) La aplicación tiene incorporadas tecnologías VR/AR.

21) La aplicación utiliza las funciones de geolocalización del móvil.

22) La aplicación dispone de tecnología QR Code. 


\subsection{Universo de investigación}

La muestra del trabajo para la presente investigación está constituida por un total de 17 aplicaciones móviles oficiales correspondientes a las capitales de comunidades autonómas de España.

Hemos decidido limitar nuestra muestra al universo de las capitales de comunidades autónomas, porque de este modo hemos podido incluir en la investigación todo el espacio territorial español y tener una imagen global sobre cómo está evolucionando este instrumento de comunicación en cada una de ellas.

Los ayuntamientos tomados en cuenta para esta investigación se encuentran en la siguiente enumeración (tabla 1).

Tabla 1. Listado de comunidades autónomas y sus capitales

\begin{tabular}{ll}
\hline Comunidad autónoma & Capital comunidad autónoma \\
\hline Andalucía & Sevilla \\
\hline Aragón & Zaragoza \\
\hline Asturias & Oviedo \\
\hline Islas Baleares & Palma de Mallorca \\
\hline Islas Canarias & Santa Cruz de Tenerife \\
\hline Cantabria & Las Palmas de Gran Canaria \\
\hline Castilla-La Mancha & Santander \\
\hline Castilla y León & Toledo \\
\hline Cataluña & Valladolid \\
\hline Extremadura & Barcelona \\
\hline Galicia & Mérida \\
\hline La Rioja & Santiago de Compostela \\
\hline Comunidad de Madrid & Logroño \\
\hline
\end{tabular}




\begin{tabular}{ll}
\hline Comunidad autónoma & Capital comunidad autónoma \\
\hline Navarra & Pamplona \\
\hline País Vasco & Vitoria \\
\hline Melilla & \\
\hline Región de Murcia & Murcia \\
\hline Comunidad Valenciana & Valencia \\
\hline
\end{tabular}

Fuente: Elaboración propia

\subsection{Recursos empleados}

Los recursos y medios con los que se cuentan para realizar la investigación planteada son tanto propios, como ofrecidos por la Universidad Abat Oliba CEu. En primer lugar, para elaborar este artículo, hemos hecho uso de los recursos bibliográficos que ha puesto a nuestra disposición la universidad, entre ellos: acceso a la consulta de todas las fuentes primarias y secundarias disponibles en la Biblioteca CEU, acceso a tesis doctorales depositadas, acceso a datos internacionales como Ebsco Host, Scopus, Web of Science o Dialnet.

En segundo lugar, hemos tenido a nuestra disposición todos los recursos necesarios para recopilar los materiales multimedia propios de las instituciones públicas sujetas a este estudio y realizar un banco propio compuesto de: sitios web, blogs, micrositios, aplicaciones móviles, etc.

También, disponemos de los dispositivos electrónicos necesarios para probar las nuevas tecnologías utilizadas en la comunicación institucional, de los cuales enumero una parte: ordenador portátil, teléfono inteligente, gafas de realidad virtual, videocamara de realidad virtual, etc.

Por último, pero no menos importante, disponemos de los programas de análisis de datos sPss y Tableau, material bibliográfico y apoyo económico para desplazarnos a Argentina y realizar las entrevistas en profundidad con un especialista en comunicación vinculado a la trasparencia institucional. 


\section{OBJETIVOS}

\subsection{Hipótesis de trabajo}

En relación al objeto de estudio, las hipótesis de partida de la investigación son las siguientes:

H1: Dadas las diferencias de formato entre los portales web institucionales y las aplicaciones móviles, en lo que representa los elementos de interfaz y usabilidad, presuponemos que va haber una diferencia entre los niveles de transparencia de las aplicaciones móviles de los ayuntamientos y los niveles de transparencia correspondientes ofrecidos del mapa InfoParticipa.

H2: En el contexto dado, en el cual los portales de transparencia y los sitios web institucionales aparecieron antes que las aplicaciones dedicadas a mantener el contacto entre el ciudadano y las instituciones públicas, presuponemos que el canal de comunicación con mayor nivel de transparencia y un mayor desarrollo al nivel de la participación ciudadana va ser el que tenga más antigüedad.

\subsection{Objetivos del estudio}

En relación al objeto de estudio y las hipótesis de partida, los objetivos de la investigación, son los siguientes:

O1: Conocer cuáles son las nuevas tecnologías más utilizadas por parte de las instituciones públicas y organizaciones del ámbito local y provincial con el propósito de favorecer la transparencia y la participación ciudadana en su ámbito geográfico. Para eso vamos enfocar el estudio en los siguientes objetivos específicos:

1) Conocer el uso de las aplicaciones corporativas de las instituciones públicas, como herramientas de generar más transparencia.

2) Conocer la utilización de las aplicaciones móviles, en el ámbito geográfico de las instituciones públicas, provinciales y locales. 
3) Conocer el uso de las redes sociales en la comunicación institucional.

4) Conocer el uso de las aplicaciones móviles en el afán de mejorar la comunicación institucional de las administraciones públicas, y si estas pueden ayudar a generar más participación ciudadana.

O2: Conocer el uso de las nuevas tecnologías en las aplicaciones móviles intitucionales en España, en lo que concierne a la comunicación institucional de las administraciones públicas locales y provinciales. Con este fin, el estudio tiene como objetivo específico el siguiente: Evaluar el nivel de la transparencia de las aplicaciones institucionales de las administraciones locales y provinciales de España, plasmando los resultados de forma comparativa.

\section{RESULTADOS}

\subsection{Presentación de los resultados globales}

Tras analizar, en parte, cada aplicación móvil institucional de los ayuntamientos considerados como muestra en este estudio, hemos transformado las fracciones de los criterios positivos sobre el total de criterios en porcentajes para poder compararlos con el nivel de transparencia de dicha ciudad en el mapa de InfoParticipa.

Tal como se puede observar en el gráfico de la figura 1, a nivel general, el nivel de transparencia de las aplicaciones móviles (las barras azules) no sigue la misma evolución que los niveles de transparencia del mapa InfoParticipa (la línea azul) para las ciudades correspondientes. A pesar del hecho de que no podemos ver una tendencia general común entre el nivel de transparencia de las aplicaciones móviles institucionales y el nivel de transparencia de la comunicación institucional global, sí que resaltan unos datos interesantes que vamos a detallar a continuación. 


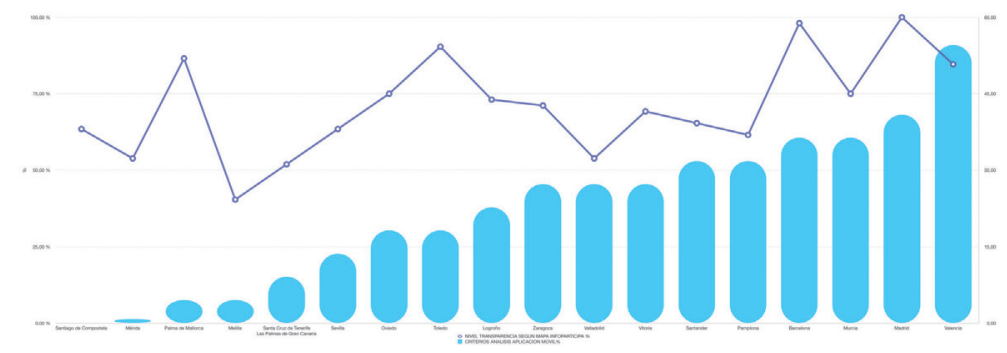

Figura 1. Gráfico comparativo entre el nivel de transparencia de las aplicaciones móviles y el nivel de transparencia marcado en el mapa InfoParticipa Fuente: Elaboración propia

Un primer dato curioso que se obtuvo tras el análisis de las aplicaciones móviles institucionales fue el hecho de que la ciudad de Santiago de Compostela, que tiene un nivel de transparencia según InfoParticipa del $63,46 \%$, no dispone de una aplicación móvil destinada a la comunicación entre el ayuntamiento y los ciudadanos. Las únicas aplicaciones disponibles en las tiendas de los dispositivos móviles son las dedicadas al turismo y, en especial, al Camino de Santiago.

Otro dato curioso aparece entre las ciudades de Palma de Mallorca y Melilla que, según el análisis de sus aplicaciones móviles institucionales, cumplen solo un criterio de los 22 supuestos para la comparación, lo que significa un nivel de transparencia a través de esta herramienta de solo un 4,55 \%. Curiosamente destaca el hecho de que Palma de Mallorca tiene un nivel de transparencia en el mapa de InfoParticipa de un 86,54 \%, mientras que Melilla alcanza solo la mitad con un nivel de transparencia de un $40,38 \%$.

El único criterio que estas ciudades cumplen de los 22 estipulados en el análisis es diferente en cada caso, la aplicación de Palma de Mallorca cumple el criterio 11, el que se refiere al hecho que los usuarios pueden comunicar incidencias, mientras la aplicación de Melilla cumple el criterio 14 , que hace referencia a los trámites que pueden hacer los ciudadanos a través de la aplicación. 
Como podemos ver en la tabla 2, Madrid, que tiene un nivel de transparencia de 100 \% según InfoParticipa, ha cumplido con solo 40,91 \% de los criterios que hemos puesto bajo análisis. Esto significa que el conjunto de aplicaciones móviles ofrecido por el Ayuntamiento de Madrid cumple tan solo con 9 de los 22 criterios. Las funciones de las cuales disponen los madrileños son las correspondientes a los criterios: 5, 7, 8, $9,10,11,12,16$ y 21. Entre las aplicaciones de las que disponen destacamos el mapa con las informaciones sobre la calidad del aire/agua.

En el caso de Barcelona, tenemos una situación similar respecto a la distribución de funciones en varias aplicaciones móviles institucionales. El conjunto de las funciones reúne un $36,36 \%$ de nivel de transparencia en las aplicaciones móviles, lo que significa 8 de 22 criterios supuestos al análisis. Los criterios positivos que se obtienen tras el estudio son: 3 , $4,10,11,16,19,21$ у 22.

La ciudad que cumple el número más alto de criterios positivos es Valencia. Los valencianos tienen un porcentaje de transparencia a través de la aplicación móvil institucional de un 54,44 \%, correspondiente a 12 criterios positivos de los 22 existentes en el estudio. Hay que destacar el hecho de que la aplicación del ayuntamiento de Valencia es la que más se acerca al prototipo de aplicación móvil de una institución del estudio.

\subsection{Comparativa entre los criterios del análisis}

Debido al hecho que el presente estudio gira alrededor de los 22 criterios que hemos analizado en las 17 aplicaciones móviles institucionales, es importante ver cuál de ellos se encuentra frecuentemente al largo del estudio. En la figura 2, podemos observar aquellos criterios que aparecen como positivos más veces en los análisis individuales de las aplicaciones móviles.

Como se puede ver, la actualización del contenido es una cuestión que se tiene en cuenta en la mayoría de las aplicaciones móviles, concretamente en 13 de las 17 analizadas. Después de la actualización de contenido, una de las funciones encontradas con frecuencia es la posibilidad de los usuarios de señalar incidencias, 11 aplicaciones móviles institucionales tienen esta opción (figura 2). 
Tabla 2. El nivel de transparencia marcado en el mapa InfoParticipa comparado con el nivel de transparencia de las aplicaciones móviles

\begin{tabular}{lcc}
\hline & $\begin{array}{c}\text { Nivel transparencia } \\
\text { según mapa } \\
\text { infoparticipa } \\
\%\end{array}$ & $\begin{array}{c}\text { Criterios } \\
\text { análisis aplicación } \\
\text { móvil } \\
\%\end{array}$ \\
\hline Valencia & $84,62 \%$ & $54,55 \%$ \\
\hline Madrid & $100,00 \%$ & $40,91 \%$ \\
\hline Murcia & $75,00 \%$ & $36,36 \%$ \\
\hline Barcelona & $98,08 \%$ & $36,36 \%$ \\
\hline Santander & $65,38 \%$ & $31,82 \%$ \\
\hline Pamplona & $61,54 \%$ & $31,82 \%$ \\
\hline Zaragoza & $71,15 \%$ & $27,27 \%$ \\
\hline Vitoria & $69,23 \%$ & $27,27 \%$ \\
\hline Valladolid & $53,85 \%$ & $27,27 \%$ \\
\hline Logroño & $73,08 \%$ & $22,73 \%$ \\
\hline Toledo & $90,38 \%$ & $18,18 \%$ \\
\hline Oviedo & $75,00 \%$ & $18,18 \%$ \\
\hline Sevilla & $63,46 \%$ & $13,64 \%$ \\
\hline Santa Cruz de Tenerife & $51,92 \%$ & $9,09 \%$ \\
\hline Palma de Mallorca & $86,54 \%$ & $4,55 \%$ \\
\hline Melilla & $40,38 \%$ & $4,55 \%$ \\
\hline Mérida & $53,85 \%$ & $0,80 \%$ \\
\hline Santiago de Compostela & $63,46 \%$ & $0,00 \%$ \\
\hline & & \\
\hline
\end{tabular}

Fuente: Elaboración propia 


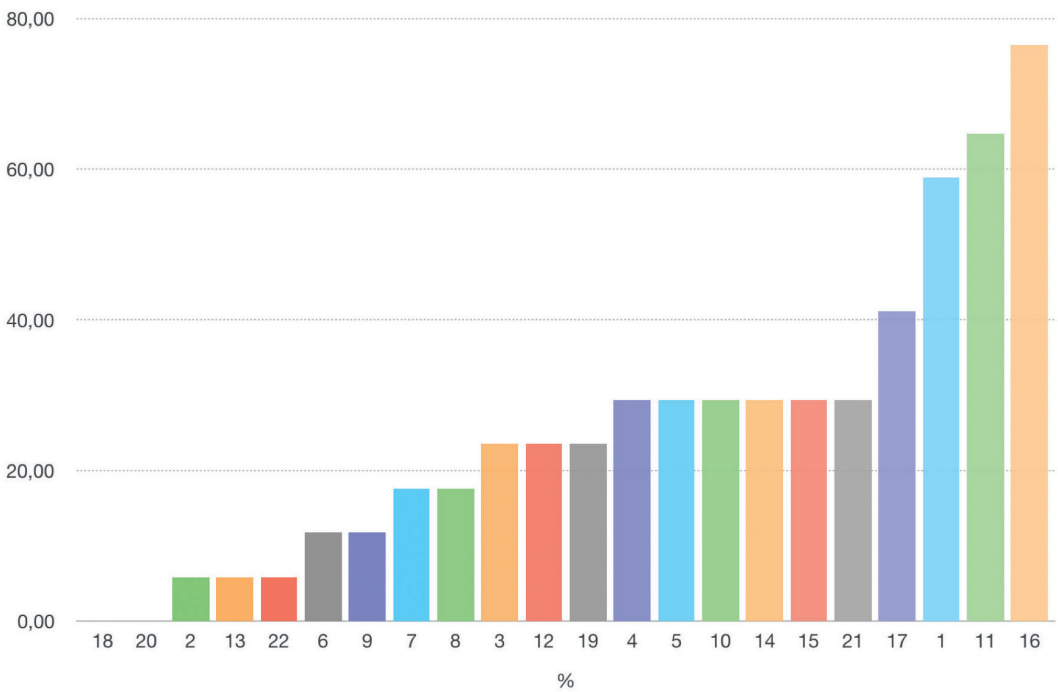

Figura 2. Gráfico comparativo entre los criterios del estudio Fuente: Elaboración propia

Uno de los criterios más importantes, el que se refiere a que los usuarios tengan acceso a información relevante sobre su comunidad, se encuentra en solo 10 de las 17 aplicaciones móviles analizadas.

Dos de las funciones tomadas en cuenta en el estudio para analizarse y comprobar si existen en las aplicaciones móviles institucionales son la accesibilidad al servicio por parte de las personas discapacitadas y la incorporación de las tecnologías VR/AR. Tras analizar las 17 aplicaciones incluidas en el estudio, ha resultado que ninguna de ellas tiene este tipo de funciones.

\subsection{Comparativa entre las categorías de los criterios del análisis}

Para tener una imagen global sobre cuál es la situación actual de las aplicaciones móviles institucionales en relación con las posibilidades 
de mejora y las expectativas de los ciudadanos, es necesario comparar entre ellas las categorías de criterios que tenemos en este estudio (figura 3).

Con un porcentaje de 35,29 \% la categoría destinada a las actualizaciones y a la accesibilidad es la que tiene más criterios positivos entre las 17 aplicaciones analizadas.

A diferencia de solo cinco puntos porcentuales, le sigue el segundo con un $30,59 \%$, se trata de la categoría destinada a los servicios a los cuales tienen acceso los ciudadanos a través de las aplicaciones móviles institucionales.

La categoría destinada a la información relevante disponible para los usuarios reúne tan solo un 26,47 \% del total de los criterios de su tipología para las 17 aplicaciones analizadas.

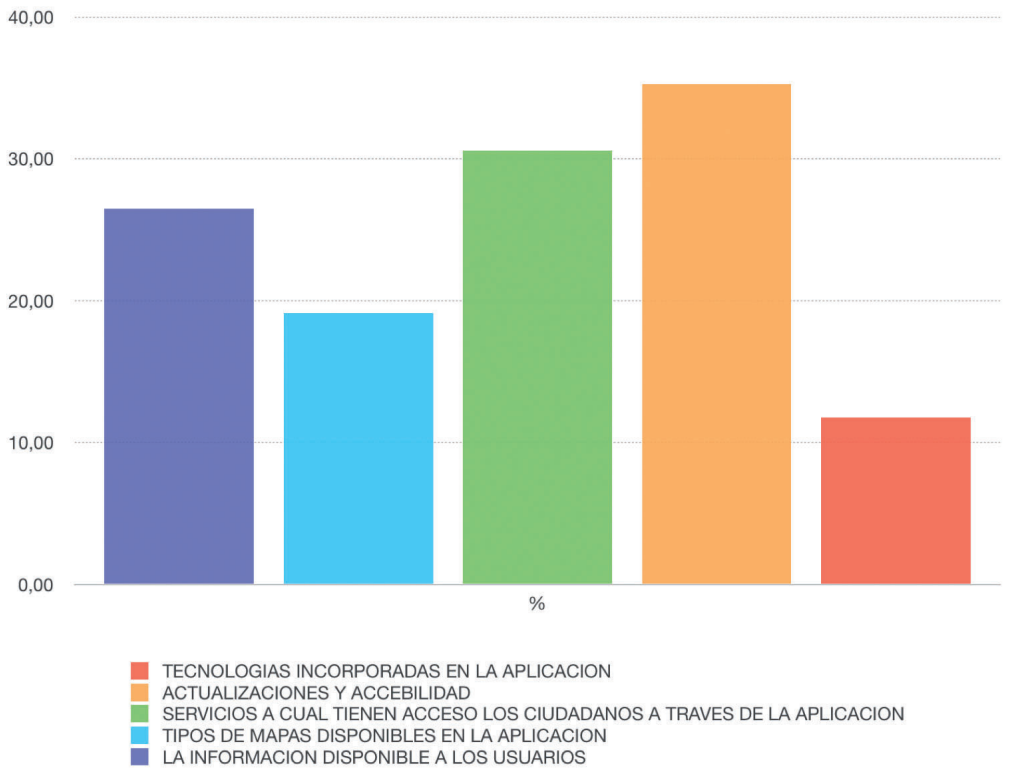

Figura 3: Gráfico comparativo entre las categorías de los criterios del estudio Fuente: Elaboración propia 
Teniendo tan solo un porcentaje de 19,12 \% le sigue la categoría designada a los tipos de mapas disponibles en las aplicaciones móviles analizadas. Con un porcentaje muy bajo, de solamente $11,76 \%$ la categoría que reúne los criterios para tecnologías incorporadas en la aplicación nos da una idea de cuánto margen de mejora queda respecto a este tipo de herramienta digital.

\subsection{Diseño de las aplicaciones móviles analizadas en el estudio}

Tras analizar las 17 aplicaciones móviles institucionales, las de cada capital de comunidad autónoma, es importante decir que en el análisis comparativo se han tenido en cuenta solamente criterios de orden funcional y no se han introducido elementos de usabilidad.

Tal y como se puede observar en la figura 4, existen varias tipologías de diseño a la hora de analizar de forma visual las aplicaciones móviles parte del estudio. Podemos apreciar que son elecciones simplemente estilísticas pero también se podría razonar en encontrar algún vínculo entre el número de funciones previstas en la aplicación y el diseño. Por el tamaño de la muestra, es imposible en este momento sacar una conclusión de este tipo, para eso se debería ampliar el estudio a un número mayor de aplicaciones y diversificar el propósito con cual dichas aplicaciones han sido creadas.

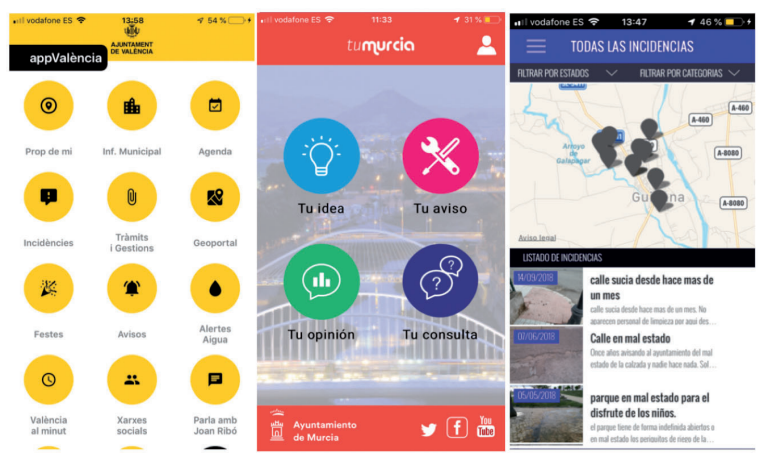

Figura 4: Captura de pantada de aplicaciones móviles (de izquierda a derecha) Valencia, Murcia, Madrid Fuente: Elaboración propia 


\section{CONCLUSIONES}

Al final del artículo, sería oportuno reflexionar sobre qué es verdaderamente comunicar en el espacio público por parte de una institución como es un ayuntamiento. A veces caemos en la tentación de comprender el acto de comunicar con el simple hecho de transmitir informacion. Es verdad que en ambos casos hablamos de generar contenido, de redactar mensajes hacia nuestros públicos, pero si estas acciones las hacemos incontroladamente sin tener un filtro y sin adaptar los mensajes a los oyentes, nos encontraremos con una intoxicación de información sin que suceda el acto de comunicar. Partiendo de esta idea, nuestro estudio trató de entender en que forma las instituciones públicas locales se relacionan con sus públicos en el medio digital.

Una vez introducida la Ley de Transparencia 19/2013 en España, se abrió el camino hacia una actitud más abierta por parte de los actores públicos del espectro de la Administracion local, provincial o nacional. El concepto de publicidad activa empezó a presionar y ayudar a una mejor transparencia por parte de la Administración Pública.

De este modo la Ley de la Transparencia 19/2013 puede ser considerada un punto de partida importante para los profesionales de la comunicación online que quieren innovar en este sector donde la forma en cual se hace llegar la información parece atrapada en un paradigma digital que ya no responde plenamente a las necesidades actuales de los usuarios activos de las nuevas tecnologías. Es por eso que con la ayuda de estas nuevas herramientas tecnológicas se puede aumentar el grado en el cual la información llega de forma eficaz a los ciudadanos.

Al principio de nuestra investigación, hemos enunciado una serie de hipótesis que nos sirvieron de partida para analizar todo este análisis sobre las aplicaciones móviles institucionales. La primera de ellas se refería a las diferencias de formato entre los portales web institucionales y las aplicaciones móviles en lo referente a los elementos de interfaz y usabilidad, y presuponíamos que habría una diferencia entre los niveles de transparencia de las aplicaciones móviles de los ayuntamientos y los niveles de transparencia correspondientes ofrecidos por el mapa InfoParticipa. 
Ahora podemos afirmar que se verifica esta primera hipótesis debido al hecho de que las aplicaciones móviles están menos desarrolladas que los portales institucionales y tienen menos espacio para servir de escaparate para la cantidad de información que debe ser mostrada. Con todo eso, es importante entender que, a pesar del hecho que son diferentes, una aplicación móvil y un sitio web institucional no deben de servir de la misma forma al propósito de aumentar la transparencia. Este es el motivo por cual se han utilizado otros criterios para evaluar las aplicaciones móviles de los ayuntamientos tomados en cuenta para el estudio.

Por otro lado, hemos de decir que una aplicación que cumpla más criterios es una herramienta que sirve más a la idea de transparencia porque empodera al ciudadano con una vía más fácil, o una opción más de entrar en contacto con la información de su interés.

La segunda hipótesis que tuvimos hablaba del contexto dado, en cual los portales de transparencia y los sitios web institucionales apreciaron antes que las aplicaciones dedicadas a mantener el contacto entre el ciudadano y las instituciones públicas. En aquel entonces presuponíamos que el canal de comunicación con mayor nivel de transparencia y un mayor desarrollo a nivel de la participación ciudadana va ser el que tenga más antigüedad. La hipótesis se valida parcialmente, en el sentido que va a haber un grado mayor de transparencia porque hay más información recogida en este momento en los portales web que en las aplicaciones, pero por otro lado las aplicaciones tienen infinitas opciones de difundir la información al ciudadano y de captarle la atención. Por solo decir una de ellas, nos podemos referir a la función de notificaciones directas en el móvil, de poder alertar al ciudadano sobre posibles cambios en los horarios, alertas o cualquier otra información relevante para el usuario.

Esta investigación ha clarificado algunas de las dudas que teníamos respeto esta herramienta digital que nos puede ser de ayuda real en la comunicación institucional, pero hay aún peguntas a las cuales podremos responder juntos si ampliamos el estudio a más tipos de aplicaciones. 
Por ejemplo, podríamos investigar más sobre la usabilidad y entender cómo diseñar una aplicación que sirva mejor a su uso de comunicar y mantener cerca a su público objetivo: el ciudadano. Uno de los tipos de aplicaciones con el cual podríamos comparar las 17 aplicaciones presentes en este estudio en el futuro, sería con las aplicaciones homólogas destinadas al turismo. De esta forma comprenderíamos cómo servir a diferentes necesidades como una sola institución pública.

\section{BIBLIOGRAFÍA}

Abidin, C. 2018. Internet Celebrity: understanding fame online. Bingley: Emerald Publishing.

Álvarez Nobell, Alejandro, Gabriel Sadi y Verónica Méndez. 2016. «La institucionalización de la investigación en comunicación institucional y relaciones públicas en la Argentina». En La pantalla insomne (2. ${ }^{a}$ edición ampliada), eds. Concha Mateos, Concha y Javier Herrero.

Almansa Martínez, A. y A. Castillo-Esparcia. 2014. «Comunicación Institucional en España. Estudio del uso que los diputados españoles hacen de las Tic en sus relaciones con la ciudadanía». Chasqui: Revista Latinoamericana de Comunicación, 126: 22-30.

Baracaldo-Lozano, N. 2013. «¿Es garante del principio de transparencia la implementación de normas internacionales en Colombia?». Cuadernos de Contabilidad, 14: 1097-1120.

Baraibar-Díez, E. y L. Luna-Sotorrío. 2012.«Transparencia social e hipótesis del impacto social. Análisis en el IBEX35». Universia Business Review, 36: 108-123.

Caba Pérez, Carmen. 2007. «La cuenta de inversión argentina frente a los compromisos adquiridos por el programa "transparencia en las cuentas públicas"». Administración Pública y Gestión Estatal, 6 (8): 81-105.

Canel, M. J. 1999. «Comunicación política: técnicas y estrategias para la sociedad de la información». Madrid: Tecnos. 
Cea D'Ancona, M. ángeles. 1998. Metodología cuantitativa, Estrategias y técnicas de investigación social. España: Editorial Síntesis.

Cid, F. 2018. «Transparencia en comunicación interna: ¿Hasta dónde llega la confidencialidad de las decisiones empresariales?». Capital Humano, 31 (330): 24.

Sanz Santolaria, C. J. y J. P. González González. 2012. «Memorias de sostenibilidad: una corriente de transparencia». Partida Doble, 23 (241): 76-83.

Vera Martínez, M. C., D. Rocha Romero y M. C. Martínez Rodríguez. 2015. «El modelo de gobierno abierto en América latina: paralelismo de las políticas públicas de transparencia y la corrupción». Íconos, 53: 85-103. 


\title{
DISCURSO DE CLAUSURA
}

\author{
Carlos Fanjul Peyró \\ Director aCAdÉmico del ComLoc 2018 \\ Universitat Jaume I. Castelló
}

$\mathrm{E}$

N PRIMER LUgar, QUIERO AgRADECER a todos los que han hecho posible el buen desarrollo de este ComLoc 2018 por su participación, esfuerzo, interés e implicación. Como sabéis, este año el congreso ha versado sobre el negocio publicitario en la sociedad digital, intentando abordar en las diferentes sesiones cómo ha afectado la irrupción del mundo online a la forma de trabajar en publicidad a nivel local, concretamente en la Comunidad Valenciana.

Empezamos la primera jornada con una magnífica charla y reflexión de mano de la profesional y profesora Dra. Chari García Cubells titulada «La evolución de la creatividad y la tecnología en el ámbito de los perfiles». Aquí se nos presentó la consolidación de esa nueva figura denominada «tecnocreativos» que ha irrumpido con fuerza dentro de la realidad de las agencias. Un nuevo perfil que combina los conocimientos informáticos y del mundo online con la formación y el espíritu creativo.

Tras esta primera reflexión, se abrió la primera mesa redonda sobre «Perfiles profesionales en el negocio publicitario actual», en donde representantes de las agencias WeAddYou, KliperDVila, Publips y Kambei nos dieron sus perspectivas y opiniones perfectamente guiadas y orquestadas por Eugenio Martín, presidente de DirCom Comunidad Valenciana y gerente de la agencia Arquetipo.

La tarde de esta primera jornada arrancó con una estupenda conferencia del Dr. Ubaldo Cuesta Cambra de la Universidad Complutense de Madrid, en donde bajo el título «Neuromarketing y publicidad: análisis de casos prácticos empleando electroencefalograma, respuesta dermoeléctrica, expresión facial implícita, eye tracking y otras variables», se nos explicaba cómo las nuevas tecnologías nos permitían conocer mejor las verdaderas motivaciones e intereses del público que muchas veces no dice u oculta, pero que de forma inconsciente las refleja y las cuales determinan gran parte de sus actitudes de consumo o compra. 
Tras esta intervención, se abrió la segunda mesa redonda del congreso bajo el título «Estructura y metodologías de trabajo en la agencia de publicidad». En esta ocasión, representantes de las agencias Trumbo, Maslow y Kids, moderados por Vicente Vañó, presidente de la asociación de agencias ComunitAd, nos relataron cómo se había modificado la forma de trabajar en publicidad debido a esa consolidación de la comunicación digital y cómo se habían adaptado los sistemas de trabajo tradicionales a la nueva coyuntura.

Como cierre de esta jornada, se desarrollaron las exposiciones de las diferentes comunicaciones sobre investigaciones realizadas acerca de la comunicación publicitaria en el mundo digital. Estas exposiciones abordaron cuestiones de gran actualidad y de sumo interés tanto a nivel académico como profesional.

El viernes 16 de noviembre comenzó la segunda jornada del ComLoc con la conferencia de la Dra. Carmen Marta Lazo de la Universidad de Zaragoza, en donde bajo el título «Competencias digitales para un consumo saludable en redes sociales» se nos invitaba a reflexionar sobre la utilización racional y moderada de estas herramientas, porque no llegamos a ser plenamente conscientes de cómo las usamos ni lo que volcamos en ellas de forma arbitraria y gratuita.

Y, finalmente, para cerrar la jornada del viernes antes del acto de clausura del congreso, tuvo lugar la tercera mesa redonda bajo el título «Nuevas tendencias estratégicas y creativas de la publicidad digital». En esta ocasión, representantes de las agencias Havas Media, Èxit, Aftershare, WeAddYou y Twelfhundred nos dieron sus diferentes perspectivas al respecto, y se confirmó la necesidad de la confluencia irremediable de la creatividad y la estrategia para conseguir la eficacia y el éxito, sea en un panorama online u offline. Todo ello fue magníficamente moderado por nuestro compañero Samuel Gil Soldevilla.

Tras esta tercera mesa, se procedió a reflexionar sobre el proyecto de investigación «El negocio publicitario en la sociedad digital» dirigido por la Dra. Cristina González Oñate y que originó el planteamiento de este ComLoc 2018; un foro de reflexión sobre la realidad publicitaria de las agencias de la Comunidad Valenciana en el mundo digital. 


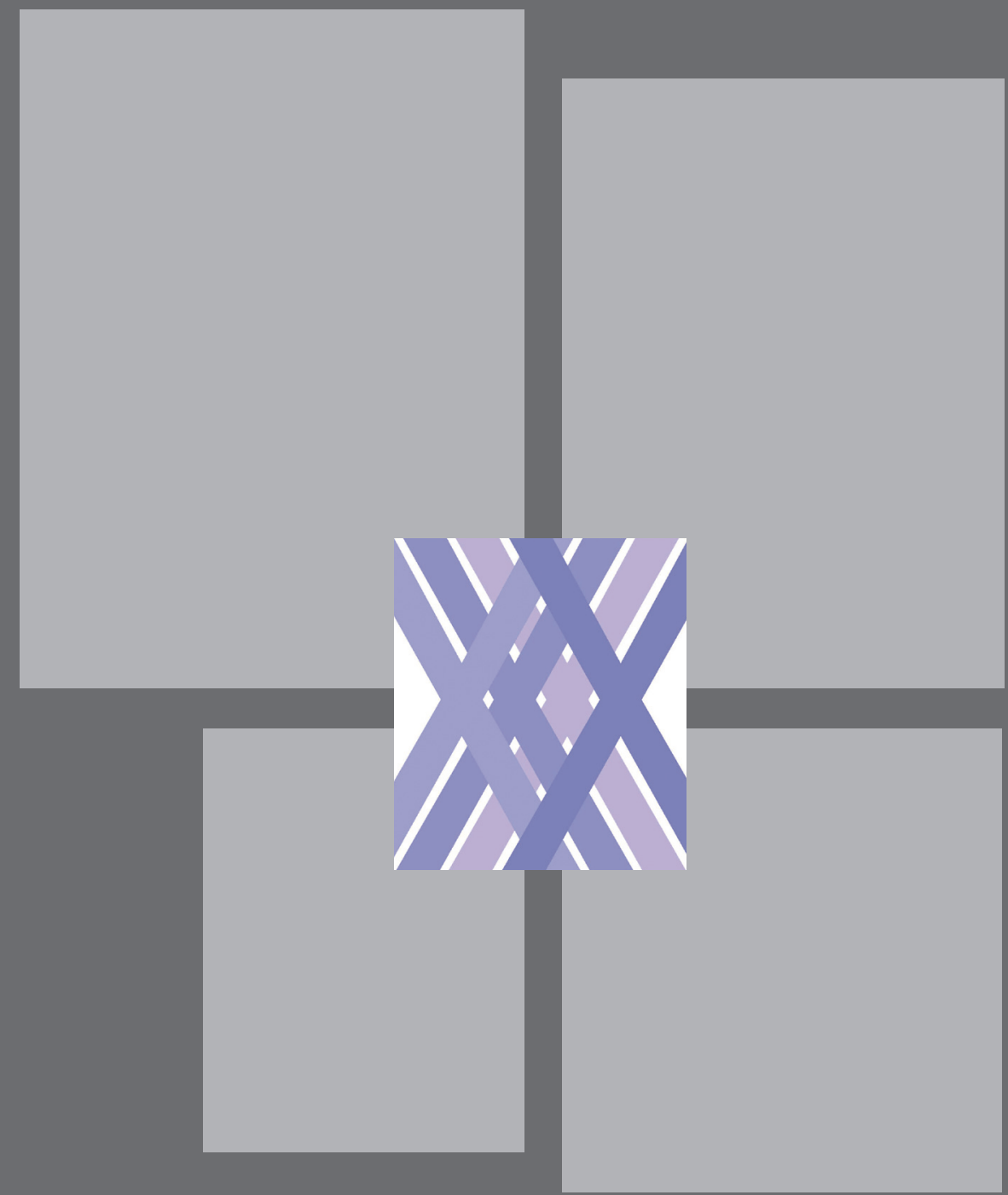

\section{1] UAUVERITAT}

Col·lecció Humanitats Núm. 59 